


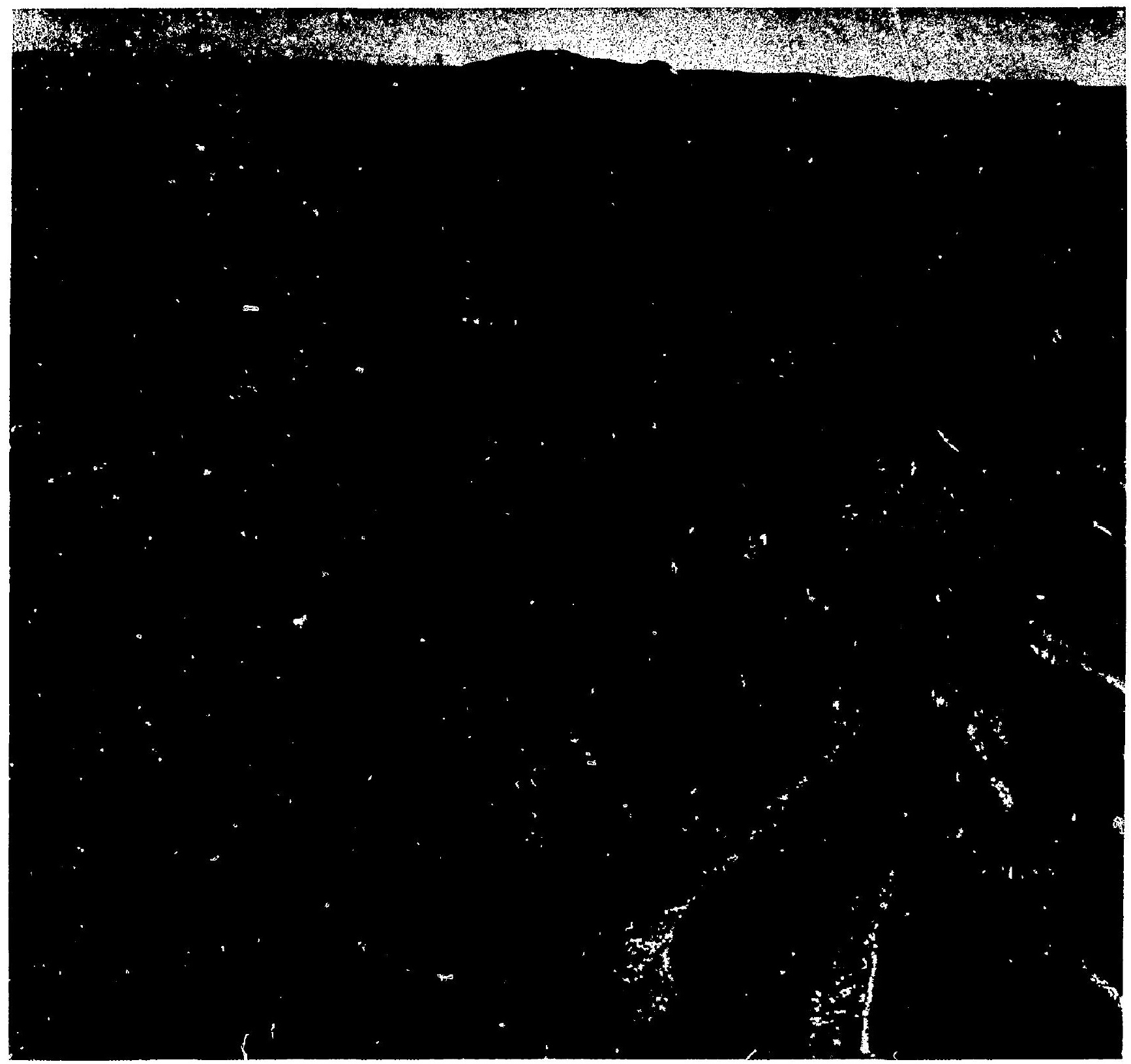

Aerial view looking west toward the Jemez Mountains across the Pajarito Plateau, which is cut into numerous narrow mesas by southeast-trending canyons. The Los Alamos townsite is in the center of the photo, the main LASL technical area (TA-3) is in the upper left, and the airport is at left center. 
LA-8200-ENV

UC-41

Issued: April 1980

\title{
Environmental Surveillance at Los Alamos During 1979
}

\author{
Environmental Surveillance Group
}
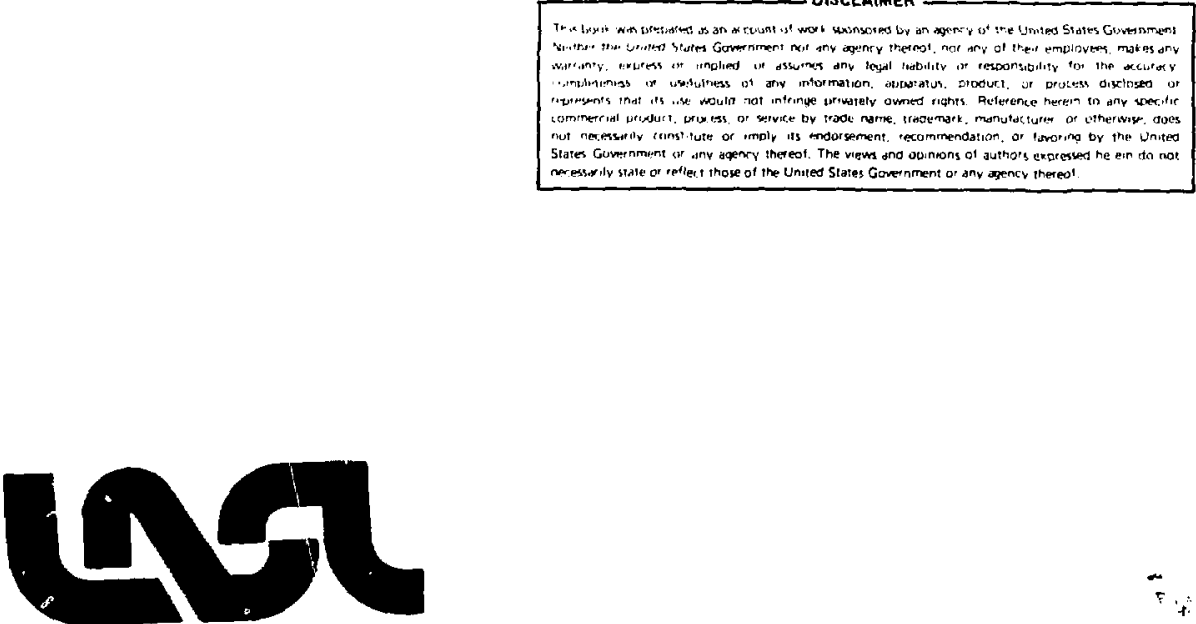

7 


\section{CONTENTS}

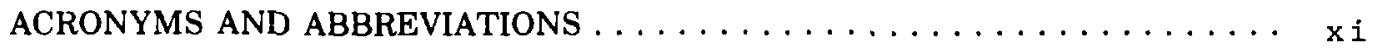
SYSTEM INTERNATIONAL PREFIXES $\ldots \ldots \ldots \ldots \ldots \ldots \ldots \ldots \ldots \ldots$

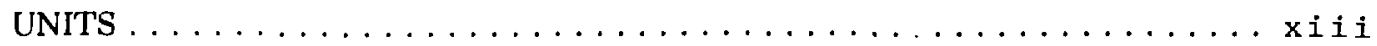

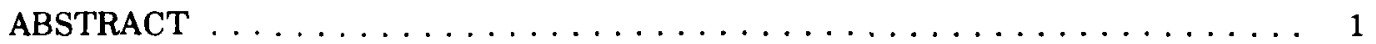

I. ENVIRONMENTAL MONITORING SUMMARY $\ldots \ldots \ldots \ldots \ldots \ldots \ldots$

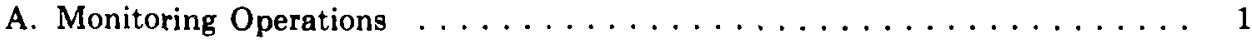

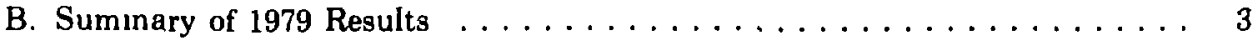

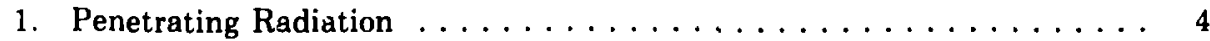

2. Radioactivity in Air and Water .................... 4

3. Radioactivity in Other Media . . . . . . . . . . . . . . . . 5

4. Radiation Doses . . . . . . . . . . . . . . . . . . . 6

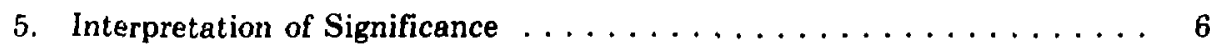

6. Other Monitoring Results . . . . . . . . . . . . . . . 7

II. BACKGROUND ON LOS ALAMOS $\ldots \ldots \ldots \ldots \ldots \ldots \ldots \ldots \ldots$

A. Physical Characteristics of the Area $\ldots \ldots \ldots \ldots \ldots \ldots \ldots \ldots$

1. Geographic Setting $\ldots \ldots \ldots \ldots \ldots \ldots \ldots \ldots \ldots \ldots$

2. Geology-Hydrology $\ldots \ldots \ldots \ldots \ldots \ldots \ldots \ldots \ldots \ldots \ldots$

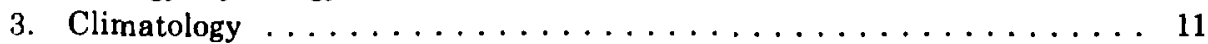

4. Population Distribution $\ldots \ldots \ldots \ldots \ldots \ldots \ldots \ldots \ldots \ldots$

B. Los Alamos Scientific Laboratory . . . . . . . . . . . . . . 11

1. Programs and Facilities .................... 11

2. Waste Management ...................... 13

III. MONITORING RESULTS $\ldots \ldots \ldots \ldots \ldots \ldots \ldots \ldots \ldots \ldots \ldots \ldots \ldots$

A. Radiation and Radioactivity $\ldots \ldots \ldots \ldots \ldots \ldots \ldots \ldots \ldots \ldots$

1. Penetrating Radiation . . . . . . . . . . . . . . . 14

2. Atmospheric Radioactivity . . . . . . . . . . . . . . 17

3. Radioactivity in Surface and Ground Waters . . . . . . . . . . 22

4. Radioactivity in Soil and Sediment . . . . . . . . . . . . 27

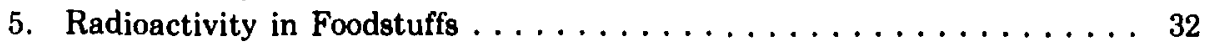

6. Radioactive Effluents $\ldots \ldots \ldots \ldots \ldots \ldots \ldots \ldots \ldots \ldots$

7. Unplanned Releases $\ldots \ldots \ldots \ldots \ldots \ldots \ldots \ldots \ldots \ldots$

B. Chemical Constituents $\ldots \ldots \ldots \ldots \ldots \ldots \ldots \ldots \ldots \ldots$

1. Chemical Quality of Surface and Ground Waters $\ldots \ldots \ldots \ldots \ldots$

2. Water Supply . . . . . . . . . . . . . . . . . 41

3. Nonradioactive Effluents . . . . . . . . . . . . . . . 42 
IV. ENVIRONMENTAL EVALUATION $\ldots \ldots \ldots \ldots \ldots \ldots \ldots \ldots \ldots \ldots$

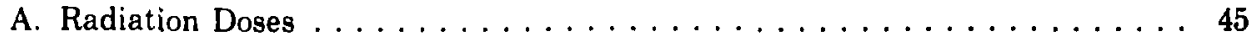

B. Environmental Protection Programs at LASL . . . . . . . . . . . 49

1. LERC/EEC Program . . . . . . . . . . . . . . . . . . . 49

2. Quality Assurance Program .................. 50

3. Archeology . . . . . . . . . . . . . . . . . . . . . . 50

4. Decontamination and Decommissioning Work . . . . . . . . . . 51

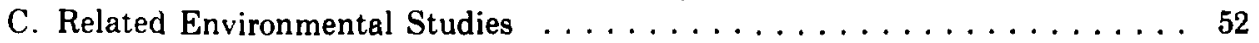

1. Fire Ecology at Bandelior National Monument . . . . . . . . . 52

2. Status of Flora in the NERP . . . . . . . . . . . . 53

3. Changes in Quality of Surface Water Related to

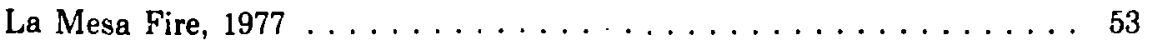

4. Fenton Hill Site (TA-57) Surface and Ground Water Quality . . . . . 54

5. Effect of Rotorilling on the Distribution of ${ }^{137} \mathrm{Cs}$ in

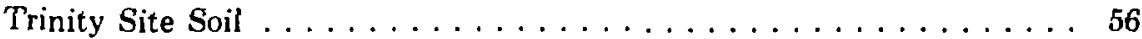

$6 \quad$ LA/NERP Elk Studies . . . . . . . . . . . . . . . . . 58

7. Computer Generated Movies to Display Biotelemetry Data . . . . . . . . 59

8. NERP Climatology Data . . . . . . . . . . . . . . . . . . . 59

9. Special Study of Radionuclides from LAMPF Lagoons . . . . . . . . . 61

10. Evaluation of Transuranic Waste Management Mcthods . . . . . . . 64

11. An Automated Transuranic Assay System for Soils . . . . . . . . . . 64

ACKNOWLEDGMENTS $\ldots \ldots \ldots \ldots \ldots \ldots \ldots \ldots \ldots \ldots$

REFERENCES . . . . . . . . . . . . . . . . . . . 69

\section{APPENDIXES}

A. STANDARDS FOR ENVIRONMENTAL CONTAMINANTS . . . . . . . . 72

B. SAMPLING PROCEDURES AND STATISTICAL TREATMENT

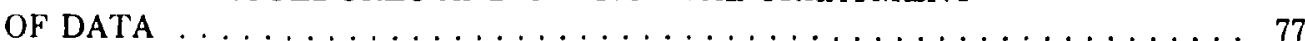

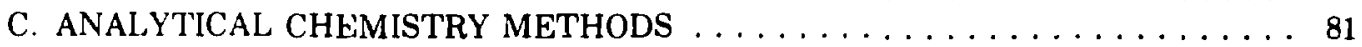

D. METHODS FOR DOSE CALCULATIONS $\ldots \ldots \ldots \ldots \ldots \ldots \ldots \ldots \ldots$

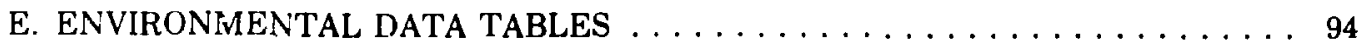

\section{FI'́UURES}

1. Topography of the Los Alamos, New Mexico area $\ldots \ldots \ldots \ldots \ldots \ldots \ldots$

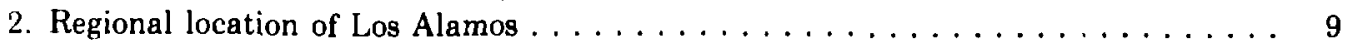

3. Conceptual illustration of geologic-hydrologic relationships in the Los Alamos area . . . . . . . . . . . . . . . . . . . . . 10

4. LASL technical and adjacent community areas $\ldots \ldots \ldots \ldots \ldots \ldots \ldots \ldots$

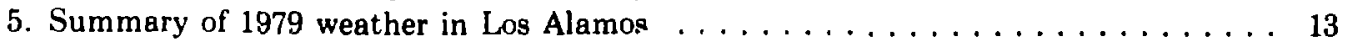

6. TLD locations on or near the LASL Site $\ldots \ldots \ldots \ldots \ldots \ldots \ldots \ldots \ldots$

7. Regional surface water, sediments, soil and air sampling locations $\ldots \ldots \ldots \ldots$

8. Quarterly dose averages for three station groups during the last four years $\ldots \ldots \ldots \ldots \ldots \ldots \ldots \ldots \ldots \ldots \ldots \ldots$

9. Air sampler locations on or near the LASL site . . . . . . . . . . . 18 
10. Monthly average long-lived gross beta activity in air,

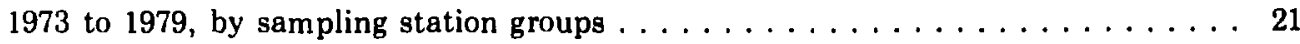

11. Annual mean atmospheric triated water vapor concentrations $\ldots \ldots \ldots \ldots \ldots$. .

12. Surface and ground water sampling locations on or near

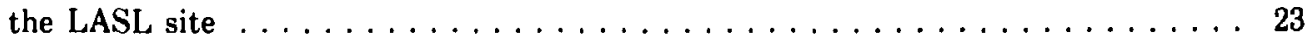

13. Soil and sediment sampling locations on or near the LASL site $\ldots \ldots \ldots \ldots$

14. Summary of atmospheric releases of ${ }^{41} \mathrm{Ar},{ }^{11} \mathrm{C}$,

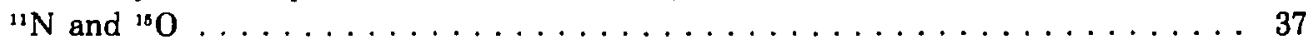

15. Summary of tritium effluents (air and liquid) $\ldots \ldots \ldots \ldots \ldots \ldots \ldots \ldots$

16. Summary of plutonium effluents (air and liquid) $\ldots \ldots \ldots \ldots \ldots \ldots$

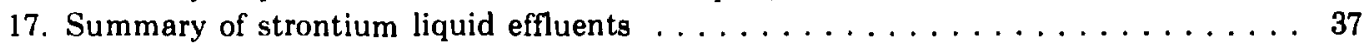

18. Two Indian pots sealed with the only known use of lime plaster found so far in the Southwest $\ldots \ldots \ldots \ldots \ldots \ldots$

19. Variation in chemical constituents in base flow in Canon de los Frijoles prior to and after the La Mesa Fire . . . . . . . . . . . . . 54

20. Variation in chemical constituents in base flow and storm runoff in Canon de los Frijoles and Capulin Canyon after the La Mesa Fire . . . . . . . . . . . . . . . . . . . . . . . 54

21. Water sampling locations in vicinity of Fenton Hill Geothermal

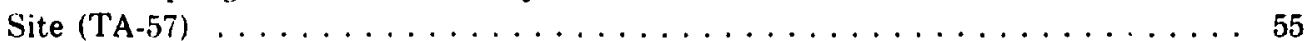

22. Summary of meteorological data from the OHL tower and ground

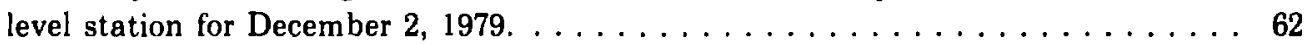

23. Sampling locations in vicinity of LAMPF lagoons $\ldots \ldots \ldots \ldots \ldots \ldots$

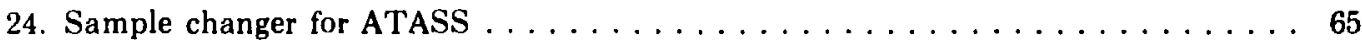

\section{TABLES}

I. LASL MONITORING PROGRAM AND NUMBER OF SAMPLING LOCATIONS $\ldots \ldots \ldots \ldots \ldots \ldots \ldots \ldots$

II. EXTERNAL PENETRATING RADIATION DURING $1979 \ldots \ldots \ldots$

III. RADIONUCLIDE CONCENTRATIONS IN AIR AND WATER AS PERCENTAGES OF CONCENTRATION GUIDES . . . . . . . . . 4

IV. COMPARISON OF INDIVIDUAL WHOLE BODY RADIATION DOSES WITH RADIATION PROTECTION STANDARDS . . . . . . . . 6

V. ADDED INDIVIDUAL CANCER MORTALITY RISKS ATTRIBUTABLE TO RADIATION EXPOSURE . . . . . . . . . . . . 7

VI. SUMMARY OF ANNUAL ATMOSPHERIC RADIOACTIVITY MONITORING FOR $1979 \ldots \ldots \ldots \ldots \ldots \ldots$. . . . . . . . 20

VII. MAXIMUM RADIOACTIVITY CONCENTRATIONS IN REGIONAL AND PERIMETER WATERS $\ldots \ldots \ldots \ldots \ldots \ldots \ldots \ldots \ldots$

VIII. MAXIMUM RADIOACTIVITY CONCENTRATICNS IN

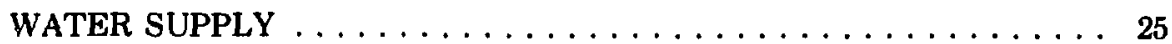

IX. MAXIMUM RADIOACTIVITY CONCENTRATIGNS IN ONSITE WATER IN AREAS NOT RECEIVING EFFLUENTS $\ldots \ldots \ldots \ldots \ldots 25$

$X$ MAXIMUM RADIOACTIVITY CONCENTRATIONS IN WATERS

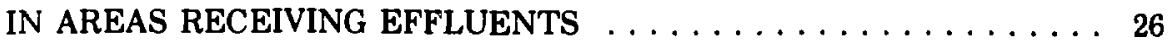

XI. MAXIMUM RADIOACTIVITY IN REGIONAL SOILS AND SEDIMENTS 
XII. MAXIMUM RADIOACTIVITY IN PERIMETER SOILS AND SEDIMENTS $\ldots \ldots \ldots \ldots \ldots \ldots \ldots \ldots \ldots \ldots \ldots$

XIII. MAXIMUM RADIOACTIVITY IN ONSITE SOILS AND SEDIMENTS $\ldots \ldots \ldots \ldots \ldots \ldots \ldots \ldots \ldots \ldots \ldots$

XIV. PLUTONIUM IN BED SEDIMENTS FROM THE RIO CHAMA $\ldots .$.
AND RIO GRANDE $\ldots \ldots \ldots \ldots \ldots \ldots \ldots \ldots \ldots \ldots \ldots$

XV. TRITIATED WATER CONTENT OF FRUITS AND VEGETABLES $\ldots 33$

XVI. PLUTONIUM CONTENT OF FRUI'TS AND VEGETABLES $\ldots \ldots \ldots 33$

XVII. RADIOACTIVITY IN FISH $\ldots \ldots \ldots \ldots \ldots \ldots \ldots \ldots \ldots \ldots$

XVIII. HTO CONCENTRATION IN HONEY SAMPLES $\ldots \ldots \ldots \ldots \ldots 36$

XIX. MAXIMUM CHEMICAL CONCENTRATIONS IN REGIONAL

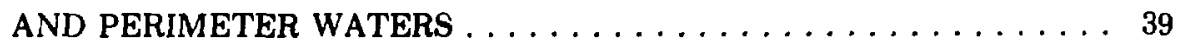

XX. MAXIMUM CHEMICAL CONCENTRATIONS IN ONSITE NONEFFLLIENT WATER ................. 40

XXI. MAXIMUM CHEMICAL CONCENTRATIONS IN EFFLUENT AREA WATERS . .................. 40

XXII. MAXIMUM CHEMICAL CONCENTRATIONS IN WATER SUPPLY .. 41

XXIII. SUMMARY OF ATMOSPHERIC PARTICULATE CONCENTRATIONS IN LOS ALAMOS AND WHITE ROCK DURING $1979 \ldots \ldots \ldots \ldots \ldots 42$

XXIV. ESTIMATES OF AIR POLLUTANT EMISSIONS ASSOCIATED WITH MAINTENANCE AND OPERATION OF THE VEHICLE FLEET $\ldots \ldots \ldots \ldots \ldots \ldots \ldots \ldots \ldots \ldots \ldots \ldots$

XXV. ESTIMATES OF STACK GAS EMISSIONS FROM THE TA-3

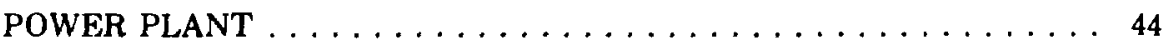

XXVI. ESTIMATED EMISSIONS FROM BURNING OF EXPLOSIVE

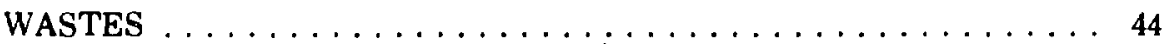

XXVII. BOUNDARY AND MAXIMUM INDIVIDUAL DOSES FROM

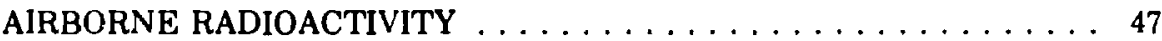

XXVIII. 1979 WHOLE BODY POPULATION DOSES TO RESIDENTS OF LOS ALAMOS COUNTY . .................. 48

XXIX. AVERAGE CONCENTRATIONS OF SELECTED ELEMENTS IN PONDS AND IN SURFACE AND GROUND WATER AT TA-57 . . . 56

XXX. CHEMICAL AND RADIOCHEMICAL CONCENTRATIONS IN

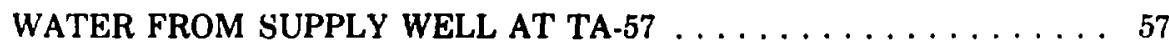

XXXI. CONCENTRATION OF ${ }^{3}{ }^{3} \mathrm{C}_{\mathrm{B}}$ IN SOIL AS A FUNCTION OF DEPTH AND TILLING AT TRINITY SITE .......... 58

XXXII. STATUS OF RADIO COLLARED ELK AS OF NOVEMBER 9, $1979 \ldots 60$ XXXIII. ANALYTICAL RESULTS OF SAMPLES TAKEN BELOW LAMPF

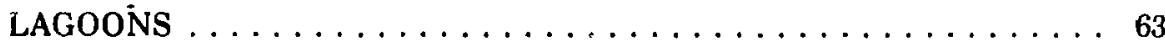

XXXIV. RADIONUCLIDE SENSITIVITY CALIBRATION FOR ATASS SYSTEM 66 XXXV. RESULTS OF EXPERIMENTS SHOWING LINEARITY OF IG DETECTOR RESPONSE TO VARYING AMOUNTS OF ${ }^{241} \mathrm{Am} \ldots \ldots, 67$

XXXVI. IG DETECTOR RESPONSE TO VARYING AMOUNTS OF WEAPONS GRADE PLUTONIUM $\ldots \ldots \ldots \ldots \ldots \ldots \ldots \ldots$

A-I. ERDA RADIOACTIVITY CONCENTRATION GUIDES (CGs) . . . . . 74 A-II. ERDA RADIATION PROTECTION STANDARDS FOR EXTERNAL AND INTERNAL EXPOSURES $\ldots \ldots \ldots \ldots \ldots \ldots \ldots \ldots \ldots \ldots$ A-III. MAXIMUNi CONTAMINANT LEVEL (MCL) IN WATER SUPPLY FOR INORGANIC CHEMICALS AND RADIOCHEMICALS $\ldots \ldots \ldots 76$ 


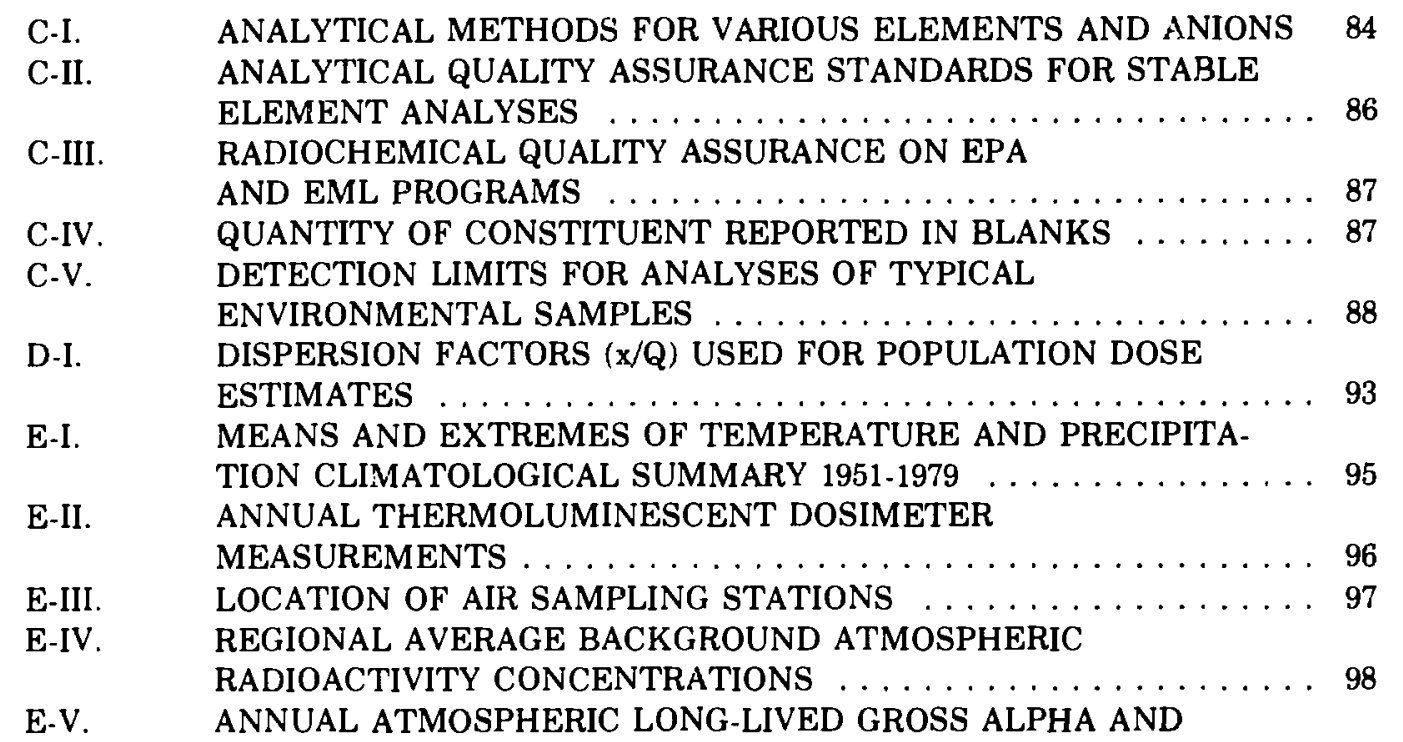

GROSS BETA ACTIVITY CONCENTRATIONS . . . . . . . . . . 99

E-VI. ANNUAL ATMOSPHERIC TRITIATED WATER VAPOR

E-VII ANNUAL ATMOSPHERIC ${ }^{238} \mathrm{Pu}$ AND ${ }^{239} \mathrm{Pu}$ CONCENTRATIONS $\ldots \ldots 101$

E-VIII ANNUAL ATMOSPHERIC URANIUM CONCENTRATIONS $\ldots \ldots \ldots 1$

E-IX. ANNUAI, ATMOSPHERIC ${ }^{241}$ Am CONCENTRATIONS . . . . . . 103

E-X. LOCATIONS OF SURFACE AND GROUND WATER STATIONS . . . 104

E-XI. RADIOCHEMICAL AND CHEMICAL QUALITY OF SURFACE

WATER FROM REGIONAL STATIONS . . . . . . . . . . . . . 107

E-XII. RADIOCHEMICAL AND CHEMICAL QUALITY OF SURFACE AND GROUND WATER FROM PERIMETER STATIONS . . . . . . . . . . 108

E-XIII. RADIOCHEMICAL, AND CHEMICAL QUALITY OF WATER FROM MUNICIPAL SUPPLY AND DIS ${ }_{1}$ RIBUTION . . . . . . . . . 110

E-XIV. RADIOCHEMICAL AND CHEMICAL QUALITY OF WATER FROM

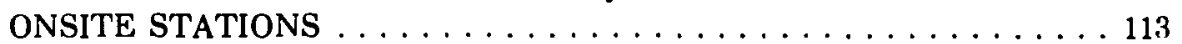

E-XV. LOCATION OF SOIL AND SEDIMENT STATIONS $\ldots \ldots \ldots \ldots$

E-XVI. RADIOCHEMICAL ANALYSES OF REGIONAL SOILS AND SEDIMENTS . . . . . . . . . . . . . . . . . . . . 119

E-XVII. RADIOCHEMICAL ANALYSES OF PERIME 2 'ER SOILS AND SEDIMENTS . . . . . . . . . . . . . . . . . 120

E.XVIII. RADIOCHEMICAL ANALYSES OF ONSITE SOILS

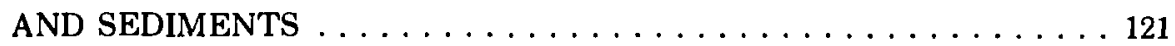

E-XIX. RADIOCHEMICAL AND CHEMICAL ANALYSES OF SNOWMELT RUNOFF . . . . . . . . . . . . . . . . . . . . 123

E-XX. ATMOSPHERIC RADIOACTIVE EFFLUENT TOTALS FOR $1979 \ldots \ldots 124$

E-XXI. TOTAL SUSPENDED PARTICULATES AT LOS ALAMOS AND WHITE ROCK DURING $1979 \ldots \ldots \ldots \ldots \ldots \ldots \ldots$

E-XXII. QUANTITIES OF VOLATILE CHEMICALS AND COMPRESSED

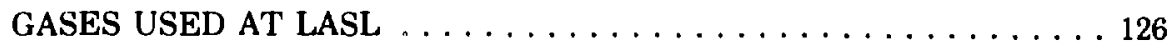

E-XXIII. ESTIMATED CONCENTRATIONS OF TOXIC ELEMENTS AEROSOLIZED BY DYNAMIC EXPERIMENTS . . . . . . . . 127 
E-XXIV. SANITARY SEWAGE TREATMENT FACILITIES EFFLUENT

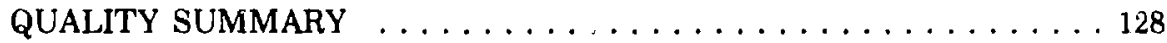

E-XXV. INDUSTRIAL LIQUID EFFLUENT QUALITY SUMMARY . . . . . . . 129 E-XXVI. QUALITY OF EFFLUENTS FROM LIQUID RADIOACTIVE WASTE TREATMENT PLANTS . . . . . . . . . . . . . . . . 131

E-XXVII. CHEMICAL QUALITY OF WATER IN VICINITY OF FENTON HILL . . . . . . . . . . . . . . . . . . . . 132

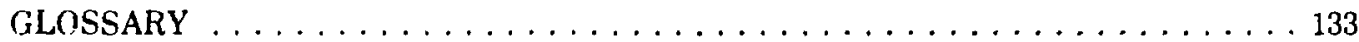

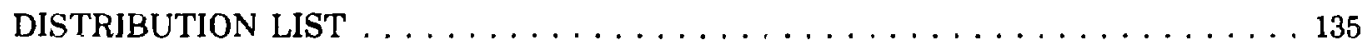




\section{ACRONYMS AND ABBREVIATIONS}

\begin{tabular}{|c|c|}
\hline $\begin{array}{l}\text { BOD, } \\
\text { COD }\end{array}$ & $\begin{array}{l}\text { 5-day biochemical oxygen demand } \\
\text { chemical oxygen demand }\end{array}$ \\
\hline CG & concentration guide \\
\hline DOE & Department of Energy \\
\hline EA & environmental assessment \\
\hline EEC & Environmental Evaluations Coordinator \\
\hline EPA & Environmental Protection Agency \\
\hline ERDA & Energy Research and Development Administration \\
\hline FEIS & final environmental impact statement \\
\hline $\mathrm{H}-7$ & Waste Management Group at LASL \\
\hline $\mathrm{H}-8$ & Enviro. mmental Surveillance Group at LASL \\
\hline HDR & hot dry rock \\
\hline HT & tritium gas \\
\hline HTO & tritiated water \\
\hline IAEA & International Atomic Energy Agency \\
\hline ICRP & International Commission on Radiation Protection \\
\hline LAMPF & Los Alamos Meson Physics Facility \\
\hline LASL & Los Alamos Scientific Laboratory \\
\hline LERC & Laboratory Environmental Review Committee \\
\hline LS-6 & Environmental Science Group at LASL \\
\hline MAP & mixed activation products \\
\hline MCL & maximum contaminant level \\
\hline MFP & mixed fission products \\
\hline $\mathbf{N}$ & normal (chemical term) \\
\hline NBS & National Bureau of Standards \\
\hline NEPA & National Environmental Policy Act \\
\hline NERP & National Environmental Research Park \\
\hline NIPDWR & National Interim Primary Drinking Water Regulations \\
\hline NMEID & New Mexico Environmental Improvement Division \\
\hline $\begin{array}{l}\text { NPDES } \\
\text { QA }\end{array}$ & $\begin{array}{l}\text { National Pollutant Discharge Elimination System } \\
\text { quality assurance }\end{array}$ \\
\hline RPS & Radiation Protection Standard \\
\hline SRM & standard reference material \\
\hline TA & technical area \\
\hline TDS & total dissolved solids \\
\hline TLD & thermoluminescent dosimeter \\
\hline TRU & transuranic wastes \\
\hline TSS & total suspended solids \\
\hline USGS & United States Geological Survey \\
\hline$\alpha$ & alpha \\
\hline$\beta$ & beta \\
\hline $\boldsymbol{\gamma}$ & gamma \\
\hline $\mathbf{s}$ & standard deviation \\
\hline $\bar{x}$ & mean \\
\hline
\end{tabular}


SYSTEM INTERNATIONAL PREFIXES

\begin{tabular}{|c|c|c|}
\hline Exponent & Prefix & Symbo \\
\hline $10^{8}$ & mega & $\mathbf{M}$ \\
\hline $10^{\mathrm{s}}$ & kilo & k \\
\hline $10^{-8}$ & milli & $\mathrm{m}$ \\
\hline $10^{-8}$ & micro & $\mu$ \\
\hline $10^{-8}$ & nano & $\mathrm{n}$ \\
\hline $10^{-12}$ & pico & p \\
\hline $10^{-18}$ & femto & f \\
\hline $10^{-10}$ & atto & a \\
\hline
\end{tabular}




\section{UNITS}

\begin{tabular}{|c|c|}
\hline Abbreviation & Unit \\
\hline c & count \\
\hline $\mathrm{aCi}$ & attocurie $\left(10^{- \text {a }}\right.$ curies $)$ \\
\hline Btu & British thermal unit \\
\hline${ }^{\circ} \mathrm{C}$ & Celsius degree \\
\hline $\mathrm{Ci}$ & curie (unit of radioactivity) \\
\hline $\mathrm{cm}$ & centimeter \\
\hline $\mathrm{fCi}$ & femtocurie $\left(10^{-18}\right.$ curies $)$ \\
\hline $\mathrm{ft}$ & foot \\
\hline $\mathbf{g}$ & gram \\
\hline $\mathrm{h}$ & hour \\
\hline in & inch \\
\hline $\mathrm{keV}$ & kiloelectron volt \\
\hline kg & kilogram \\
\hline km & kilometer \\
\hline krn ${ }^{2}$ & square kilometer \\
\hline$\ell$ & liter \\
\hline $\mathbf{m}$ & meter \\
\hline $\mathrm{m}^{\prime}$ & cubic meter \\
\hline $\mathrm{mCi}$ & millicurie ( $10^{-\mathrm{s}}$ curies) \\
\hline $\mathrm{MeV}$ & megaelectron volt \\
\hline $\mathrm{mg}$ & milligram ( $10^{-3}$ grams) \\
\hline $\min$ & minuts \\
\hline $\mathrm{m} \ell$ & milliliter $\left(10^{-8} \ell\right)$ \\
\hline $\mathrm{mm}$ & millimeter $\left(10^{-8} \mathrm{~m}\right)$ \\
\hline mrem & millirem $\left(10^{-3}\right.$ rem $)$ \\
\hline $\mathrm{mS} / \mathrm{m}$ & milliSiemens $/$ meter $(1 \mathrm{mS} / \mathrm{m}=10 \mu \mathrm{mho} / \mathrm{cm})$ \\
\hline MGD & million gallons per day \\
\hline MT & megaron ( $10^{\circ}$ tons) \\
\hline$\mu \mathrm{Ci}$ & microcurie ( $10^{-6}$ curies) \\
\hline$\mu \mathrm{g}$ & microgram (10-6 grams) \\
\hline$\mu \mathrm{m}$ & micrometer $\left(10^{-8}\right.$ meters $)$ \\
\hline $\mathrm{nCi}$ & nanocurie $\left(10^{-0}\right.$ curies $)$ \\
\hline ng & nanogram (10- grams) \\
\hline $\mathrm{pCi}$ & picocurie $\left(10^{-12}\right.$ curies $)$ \\
\hline pg & picogram $\left(10^{-12}\right.$ grams) \\
\hline rad & $62.5 \times 10^{\circ} \mathrm{MeV} / \mathrm{g}$ (unit of absorbed dose) \\
\hline rem & roentgen equivalent mean (unit of dose equivalence) \\
\hline s & second \\
\hline yr & year \\
\hline
\end{tabular}




\title{
ENVIRONMENTAL SURVEILLANCE AT LOS ALAMOS DURING 1979
}

\author{
Environmental Surveillance Group
}

\begin{abstract}
This report documents the environmental surveillance prcgram conducted by the Los Alamos Scientific Laboratory (LASL) in 1979. Routine monitoring for radiation and radioactive or chemical substances is conducted on the Laboratory site and in the surrounding region to determine compliance with appropriate standards and permit early identification of possible undesirable trends. Results and interpretation of the data for 1979 on penetrating radiation, chemical and radiochemical quality of ambient air, surface and ground water, municipal water supply, soils and sodiments, food, and airborne and liquid effluents are included. Comparisons with appropriate standards and regulations or with background levels from natural or other non-LASL sources provide a basis for concluding that environmental effects attributable to LASL operations are minor and cannot be considered likely to result in any hazard to the population of the area. Results of several special studies provide documentation of some unique environmental conditions in the LASL environs.
\end{abstract}

\section{ENVIRONMENTAL MONITORING SUM- MARY}

Los Alamos Scientific Laboratory (LASL) policy emphasizes protection of the general public and environment from any harm which could arise from Laboratory activities and mitigation of environmental impacts to the greatest degree practicable. In keeping with this policy and Department of Energy (DOF) requirements to assess and document possible ir iluences of operations on the environment, this repo1: provides data and interpretation of environ nental conditinn: in the vicinity of LASL during $1: 79$.

\section{A. Mon. toring Operations}

- Jutin monitoring for radiation, radioactive materials, and chemical substances is conducted on the Laboratory site and in the surrounding region to document compliance with appropriate standards, identify possible undesirable trends, provide information for the public, and contribute to general environmental knowledge. This monitoring in the environment is a backup to the data on specific effluent releases such as those from radioactive waste treatment plants and various stacks at nuclear research facilities.

Monitoring and sampling locations for the various types of measurements are organized in three main groups. Regional stations are located within the five counties surrounding Los Alamos County (see Fig. 1) at distances up to $80 \mathrm{~km}(50 \mathrm{mi})$ from LASL. They provide a basis for determining natural conditions beyond the range for potential influence of LASL operations. Perimeter stations are located primarily within about $4 \mathrm{~km}(2.5 \mathrm{mi})$ of the LASL boundary (see Fig. 1) and emphasize locations in the adjacent 


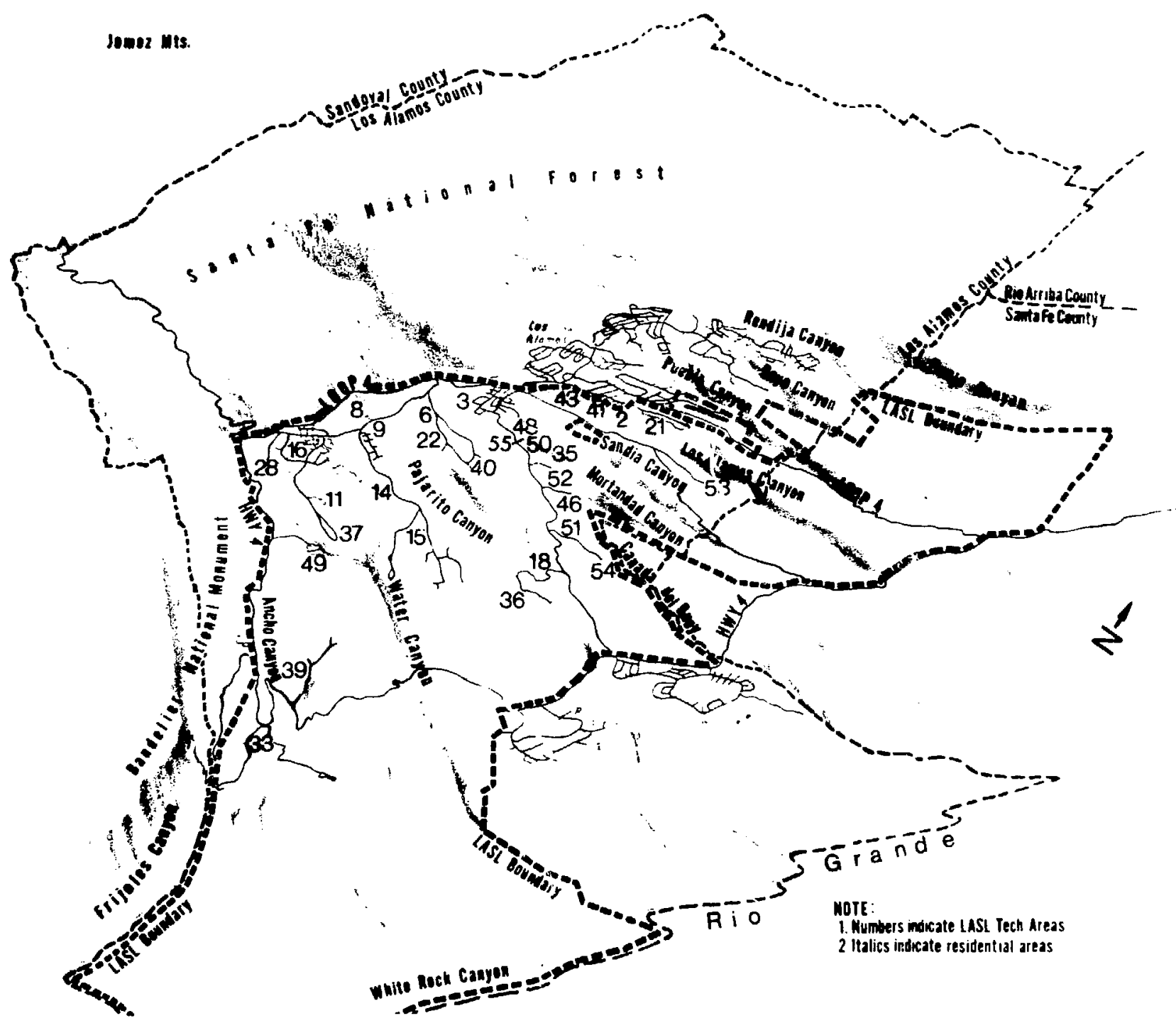

Fig. 1.

Topography of the Los Alamos, New Mexico area. 
residential and community areas. They document conditions in areas regularly occupied by the general public and likely to be influenced by LASL operations. Onsite stations are within the LASL boundary and most are in areas accessible only to employees during nominal working hours. Their data is useful for continuity of interpretation and for documentation of conditions in parts of the LASL site where the public has limited access (for example, commuters on cross-site roads or near some LASL boundaries). The number of stations in each group is shown in Table I according to the type of monitoring.

The types of routine monitoring conducted at these stations include measurements of radiation and collection of samples of air, water, soils, and foodstuffs for subsequent laboratory anaiysis. External penetrating radiation (the $x$ and gamma ray contributions from natural cosmic and terrestrial sources, plus any Latoratory contributions) was measured at 55 locations by thermoluminescent dosimeters. Airborne radioactivity samples were accumulated during monthly intervals by continuously operating samplers at 25 locations. Surface and groundwater samples were collected periodically at 113 locations: 71 of which are indicated in Table 1, 22 for the DOE water supply wells and distribution system, and 20 related to the Hot Dry Rock Geothermal Project at Fenton Hill.
Samples of foodstuffs, principally vegetables, fruit, and fish, were collected at 24 locations. Soil and sediment samples were collected periodically from 86 locations. Additional samples were collected at various times and locatione to gain information on particular events such as major runoff events in intermittent streams and nonroutine releases or for special studies. During 1979, more than 17000 analyses for chemical and radiochemical constituents were performed on these environmental samples. The resulting data were used for comparison with standards and natural background, as bases for calculations, and other interpretations.

\section{B. Summary of 1979 Results}

The large number of samples and wide range of purposes for which they are collected makes a brief summary difficult without leading to possible misinterpretation. Consequently, this summary presents an overview of monitoring results with selected highlights, emphasizing comperisons with standards or other hases for indicating significance. Full details of the results, their contexts, and interpretive methodology are explained in the body of the report and appendixes.

\section{TABLE I}

\section{LASL MONITORING PROGRAM AND NUMBER OF SAMPLING LOCATIONS}

\begin{tabular}{l}
\multicolumn{1}{c}{$\begin{array}{c}\text { Type of } \\
\text { Monitoring }\end{array}$} \\
\hline External Radiation \\
Air \\
Surface and \\
\multicolumn{1}{c}{ Ground Water" } \\
Soils and Sediments \\
Foodstuffs
\end{tabular}

Number of Sampling Stations in Group

\begin{tabular}{|c|c|c|}
\hline Regional & Perimeter & Onsite \\
\hline 3 & 12 & 40 \\
\hline 3 & 11 & 11 \\
\hline 6 & 28 & 37 \\
\hline 16 & 27 & 43 \\
\hline 8 & 7 & 9 \\
\hline
\end{tabular}

\footnotetext{
An additional 22 stations for the water supply and 20 special stations relaced to the Fenton Hill Geothermal Program were also sampled.
} 


\section{Penetrating Radiation}

Levels of penetrating radiation, including $\mathbf{x}$ and gamma rays from cosmic, terrestrial, and man-made sources in the Los Alamos area, are monitored with thermoluminescent dosimeters (TLDs) at 55 locations divided into regional, perimeter, and onsite groups. No measurements at regional or perimeter locations in the envirunmental network for any calendar quarter showed any statistically distinguishable increase in radiation levels that could be attributed to LAS $\perp$ operations (see Table II). The apparent differences between the regional and perimeter groups are attributable to differences in the nat iral radioactivity content of geologic formations. Quarterly measurements at the 16 onsite stations in the routine environmental network were expectably above background levels, reflecting ongoing research activities at LASL. Twenty-four of the forty onsite TLD stations are specially located to monitor radioactivity from the Los Alamos Meson Physics Facility (LAMPF).

\section{Radionctivity in Air and Water}

Measurements of radioactivity in air and water are compared to standards, known as Concentration
TABLE II

\section{EXTERNAL PENETRATING RADIATION DURING 1979}

\begin{tabular}{|c|c|c|c|}
\hline \multirow[b]{2}{*}{ Group } & \multicolumn{3}{|c|}{ Dose (mrem) } \\
\hline & Minimum & Maximum & Average \\
\hline Regional & 84 & 97 & 92 \\
\hline Perimeter & 112 & 14,7 & 128 \\
\hline Onsite & 109 & 252 & 144 \\
\hline
\end{tabular}

Guides (CGs) that are applicable to all federal agencies (see Appendix A). CGs are concentrations of radioactivity in air breathed continuously or water constitutin/; all that is ingested during a year that are determined to result in whole body or organ doses equel to the Radiation Protection Standards (standards for external or internal exposure to radioactivity (see Appendix A). The 1979 results for total measurements (that is, including the amount present from worldwide fallout) of the main isotopes potentially influenced by LASL operations are shown in Table III as ranges of percentages of the

TABLE III

\section{RADIONUCLIDE CONCENTRATIONS IN AIR AND WATER AS PERCENTAGES OF CONCENTRATION GUIDES•}

\begin{tabular}{lll}
\multicolumn{2}{c}{ CG } \\
\hline$\underline{\text { Regional }}$ Perimeter Onsite
\end{tabular}

$\begin{array}{llll}\text { Air } & & & \\ { }^{3} \mathrm{H} \text { (as HTO) } & 0.0-0.006 & 0.0-0.01 & 0.0-0.03 \\ { }^{239} \mathrm{Pu} & 0.0-0.03 & 0.0-0.06 & 0.0-0.07 \\ \mathrm{U} & 0.0-0.02 & 0.0-0.002 & 0.0-0.002 \\ & & & \\ \text { Water } & & & \\ { }^{\mathrm{s}} \mathrm{H} \text { (as HTO) } & 0.01-0.04 & 0.0-0.02 & 0.0-0.3 \\ { }^{239} \mathrm{Pu} & 0.0-0.01 & 0.0-0.00009 & 0.0-0.0005 \\ { }^{297} \mathrm{Cs} & 0.0-0.3 & 0.0-0.2 & 0.0-0.2\end{array}$

-Values in tables are $(\bar{x}-2 s)$ to $(\bar{x}+2 s)$ as \% CG. 
CGs. The values shown represent a statistical range (from two standard deviations below to two standard deviations above the mean) that encompasses $90-95 \%$ of the individual results. All comparisons in Table III are with CGs applicable to individuals in the general public, even though many onsite locations are not accessible to the public.

During 1979, no statistically significant difference was observed between atmospheric concentrations of gross alpha, gross beta, americium, plutoniura, and uranium measured at sampling locations along the Laboratory perimeter and those measured in distant areas. This indicates Laboratory contributions to concentrations of these contaminants were less than locsl variability in background levels. Tritiated water vapor conrentrations at four onsite stations were five to fifteen times higher than regional background levels and are attributable to LASL operations, whereas concentrations at the other seven onsite stations were statistically indistinguishable from regional background concentrations. The data in Table III show that tritium $\left({ }^{3} \mathrm{H}\right)$, plutonium $\left({ }^{230} \mathrm{Pu}\right)$, and uranium (U) atmospheric concentrations were only small fractions of their respective CGs. Results from only 1 of 55 ${ }^{298} \mathrm{Pu}$ samples and 1 of $44{ }^{201} \mathrm{Am}$ samples were above their respective analytical detection limits and were not included in Table III. Gross alpha and beta analyses serve as crude indicators of overall radioactivity levels. The highest gross alpha concentration was $3.7 \%$ of the most relevant $\mathrm{CG}$ and the highest gross beta concentration was $0.02 \%$ of the most relevant CG.

Surface and ground waters are monitored to provide routine surveillance of potential dispersion of radionuclides from LASL operations. Results of analyses are compared to CGs (see Table III) as an indication of the low concentrations or radionuctides in the environment. Other radioactivities measured but not listed in this table are ${ }^{238} \mathrm{Pu}$ (most analyses were at or below analytical detection limits), gross alpha and beta (used only as gross inuicators of radioactivity), and uranium (concentrations low and generally indistinguishable from levels naturally in the environment). Results of the 1979 radiochemical quality analyses of water from regional, perimeter, water supply, and onsite noneff́luent release areas indicate no significant effect from effluent releases from LASL. Waters in the onsite liquid effluent release areas contain measurably higher concentra- tions of radioactivity, but at levels still small fractions of CGs. These onsite waters are not a source of industrial, agricultural, or municipal water supplies.

The water supply met all applicable U.S. Environmental Protection Agency and New Mexico Environmental Improvement Division chemical quality and radioactivity standards. The integrity of the geological forrations protecting the deep groundwater aquifer was confirmed by lack of ary measurements indicative of nonnatural radioactivity or chemical contamination in municipal water supply sources.

\section{Radioactivity in Other Media}

Measurements of radioactivity in samples of soils, sediments, and a variety of foodstuffs are made to provide information on less direct natural mechanisms that could result in exposures to people. Estimated doses potentially resulting from these mechanisms, or pathways, such as wind resuspension of dust and incorporation into food chains, are summarized in the next section and compared to Radiation Protection Standards as an interpretation of their significance.

Measurements of radioactivity in soils and sediments are also useful as a means for monitoring and understanding the hydrologic transport of some radioactivity occurring in intermittent stream channels in and adjacent to the LASL site as a result of past and current liquid waste disposal operations. Pueblo, Los Alamos, and Mortandad Canyons all have concentrations of radioactivity on sediments at levels higher than attributable to worldwide fallout. Some radioactivity on sediments in Pueblo Canyon (from pre-1964 effluent disposal) and upper Los Alamos Canyon (from 1952 to current treated effluent disposal) has been transported during runoff events to the Rio Grande. Theoretical estimates, confirmed by measurements, show the incremental effect on Rio Grande sediments is small in comparison with levels of activity on soils and sediments attributable to worldwide fallout and variability in such measurements. No radioactivity on sediments has been transported past the LASL boundary in Mortandad Canyon. Measurements of above-background but low level radioactivity on soils from a few locations indicate probable deposition of some airborne emissions from LASL facilities. Most such locations are near facilities 
known to have had higher emission rates in the past, especially prior to 1974 .

Fruit, vegetable, fish, and honey samples analyzed in 1979 show no increments of radioectivity distinguishable from that attributable to natural sources or worldwide fallout at any offsite location. At onsite locations near facilities emitting tritium, some elevated levels of tritiated water were found in fruit and in honey from an experimental hive.

\section{Radiation Doses}

Individual whole-body radiation doses to members of the public attributable to LASL operations are compared to applicable Radiation Protection Standz: ds (RPSs) in Table IV. Radiation doses for various mechanisms of exposure are expressed as a percentage of the $500 \mathrm{mrem} / \mathrm{yr}$ RPS. This RPS is only for doses from exposures above natural background and medical exposures. Doses presented here are those calculated to be possible doses to individuals under realistic conditions of exposure and do not include some of the maximum hypothetical exposures discussed in the body of this report that have minimal likelihood of occurring.

The estimated maximum regional doses shown in Table IV for direct external radiation and airborne radioactivity are both based on exposure to theoretically calculated concentrations of emissions from LAMPF and the research reactor. The maximum estimated regional dose based on a food pathway assumes consumption of liver from a steer that grazed in Los Alamos Canyon and drank water containing some radioactivity on suspended sediments during a long spring runoff. Estimated perimeter doses from direct external radiation and airborne radioactivity occur at a commerciul establishment near the LASL boundary north of LAMPF and are attributable to its operation. The perimeter food pathway is based on consumption of honey from an experimental hive located onsite but near the LASL boundary. The onsite external radiation dose is that estimated for a commuter regularly travelling past a LASL facility on one of the DOE roads normally open to public travel. The onsite airborne pathway was calculated for a half-day visit to the science museum-personnel building area. The onsite fcod pathway could occur from consumption of venison from a deer frequenting a canyon where treated liquid effluents are discharged. Another perspective is provided by comparing these estimated doses with the estimated whole body dose attributable to worldwide fallout (from inhalation, ingestion of (ood, and external radiation) in the United States, which is about $0.9 \%$ of the RPS.

\section{Interpretation of Significance}

To provide a perspective for comparing the significance of radiation exposures, estimates of the added risk of cancer were calculated. The increase in risk estimated for average individual exposures to ionizing radiation from LASL operations are presented in Table $V$, along with estimated incremental risks from natural and diagnostic medical radiation. The factors for risk estimation are those

TABLE IV

COMPARISON OF INDIVIDUAL WHOLE BODY RADIATION DOSES WITH RADIATION PROTECTION STANDARDS

(Values are per cent of RPS. For Individual in Public: $500 \mathrm{mrem} / \mathrm{yr}$ )

Calculated Doses Attributable to LASL Operations from:

Direct External Radiation

Airborne Radioactivity

Food Pathways
$\%$ RPS

\begin{tabular}{|c|c|c|}
\hline Regional & Perimeter & Onsite \\
\hline$<0.001$ & 0.6 & 0.1 \\
\hline$<0.001$ & 0.6 & $<0.001$ \\
\hline$<0.001$ & 0.005 & 0.8 \\
\hline
\end{tabular}




\section{TABLE V}

\section{ADDED INDIVIDUAL CANCER MORTALITY RISKS ATTRIBUTABLE TO RADIATION EXPOSURE}

\section{Exposure Source}

Average Exposure from LASL Operations

Los Alainos Townsite

White Rock Area

\author{
Natural Radiation \\ Cosmic and Terrestrial \\ Los Alamos Townsite \\ White Rock Area \\ Self Irradiation
}
Medical x-rays (Diagnostic Procedures) Average Whole Body Exposure

\author{
Added Risk (Chance) \\ of Cancer Mortality
}

1 in 13000000

1 in 130000 oce

\author{
Dose (mrem) \\ Uned in Risk Eatimate
}

1 in 88000

1 in 96000

1 in 420000

1 in 97000
0.8

0.08

-Based on measured dose rates with reductions made for structural and self-shielding.

given by the International Commission on Radiological Protection (ICRP) based on observed radiation damage at high doses and linearly extrapolated to effects at low doses and dose rates (that is, the injury is assumed to be directly proportional to dose). The ICRP warns that these radiation risk estimates should be used only with great caution because the factors may overestimate actual risk. The National Council on Radiation Protection and Measurements (NCRP) has also taken the official position that linear extrapolation methods "have such a high probability of overestimating the actual risk as to be of only marginal value, if any, for purposes of realistic risk-benefit evaluation." Thus, one must keep in mind that the radiation risks are likely to be less than stated in Table V.

The maximum potential LASL contribution to the cancer risk is extremely small when compared to overall cancer risks. Further perspective is gained by noting the average risk in New Mexico of contracting a cancer from all causes is 1 chance in 405 each year. The overall United States lifetime risk of contracting some form of cancer is 1 chance in 4 and the lifetime risk of cancer mortality is 1 chance in 5 .

\section{Other Monitoring Results}

Airborne radioactive emissions were monitored as released from 90 exhaust stacks at LASL and were typical of releases during the past several years. The greatest change during 1979 was an increase in plutonium emissions by a factor of about 10 due to problems in one experimental facility. This did not result in any increase in average ambient air concentrations offsite distinguishable from worldwide fallout. Tritium emissions decreased somewhat in spite of a release of about $3000 \mathrm{Ci}(0.3 \mathrm{~g})$ from an accident in one experimental laboratory. No measurable offsite effect resulted, and the maximum theoretically calculated dose was less than $0.05 \%$ of the RPS. Liquid effluents from two radioactive waste treatment plants and one sanitary sewage lagoon contained some radioactivity, all at levels well within CGs.

Nonradioactive effluents include airborne and liquid discharges. Airborne effluents from the beryllium fabrication shop, gasoline storage and combugtion, power plant, gases and volatile chemicals, waste explosive burning, and dynamic testing did 
not result in any measurable or theoreticall:; calculable degradation of air quality. A single National Pollutant Discharge Elimination System (NPDES) permit covers 108 industrial discharge points and 10 sanitary sewage treatment facilities. This year 6 of the 10 sanitary sewage treatment facilities exceeded one or more of the NPDES limits (excluding flow rate limitations) in one or more months, and less than $1 \%$ of all samples from the 108 industrial outfalls exceeded NPDES limits.

Some special envizonmental research programs were conducted this year to gain a better understanding of the ecosystems at LASL. Among these projects were the study of fire ecology, flora, water quality, elk migration, climatology, transuranic waste management methods, and radionuclide detection instrumentation.

\section{BACKGROUND ON LOS ALAMOS}

\section{A. Physical Characteristics of the Area}

\section{Geographic Setting}

The Los Alamos Scientific Laboratory and associated residential areas of Los Alamos and White Rock are located in Los Alamos County in northcentral New Mexico, aproximately $100 \mathrm{~km}(60$ mi.) NNE of Albuquerque and $40 \mathrm{~km}(25 \mathrm{mi}$.) NW of Santa Fe (Fig. 2). The $111 \mathrm{~km}^{2}$ (27 500 acres) Laboratory site and adjacent communities are situated on Pajarito Plateau. The Plateau consists of a series of finger-like mesas separated by deep eastwest oriented canyons cut by intermittent streams. The mesa tops range in elevation from approximately $2400 \mathrm{~m}(7800 \mathrm{ft})$ at the flank of the Jemez Mountains to about $1800 \mathrm{~m}(6200 \mathrm{ft})$ on their eastern margin terminating above the Rio Grande valley.

Most Laboratory and community developments are confined to mesa tops (see Fig. 1 and inside front cover). The surrounding land is largely undeveloped with large tracts of land north, west, and south of the Laboratory site held by the U.S. Forest Service and U.S. Park Service (see land ownership map inside back cover). The Pueblo de San Ildefonso borders the Laboratory to the east.

All Los Alamos County and vicinity locations referenced in this report are identified by the LASL cartesian coordinate system, which is baseci an English units of measurement. This system is standard throughout the Laboratory but is independent of the U.S. Ceological Survey and New Mexico Siate Survey coordinace sytems. The major coordinate markers shown on the maps are at $3.048 \mathrm{~km} \mathrm{(10000}$ $\mathrm{ft}$ ) intervals, but for the purpose of this report are identified to the nearest $0.30 \mathrm{~km}(1000 \mathrm{ft})$. The area within the LASL boundary is controlled by the DOE, which has the option to completely restrict access. This control can be instituted when necessary.

\section{Geology-Hydrology}

Canyons and mesas in the Luboratory area are generally formed by Bandelier Tuff (see Fig. 3, tuff) composed of ashfall and ashflow pumice and rhyolite tuff that form the surface of Pajarito Plateau. The tuff ranges from nonwelded to welded and is in excess of $300 \mathrm{~m}(1000 \mathrm{ft})$ thick in the western part of Pajarito Plateau and thins to about $80 \mathrm{~m}$ (260 ft) toward the east above the Rio Grande. It was deposited as a result of a major eruption of a volcano in the Jemez Mountains to the west about 1.1 to 1.4 million years ago.

The tuffs lap onto older volcanics of the Tschicoma Formation, which form the Jemez Mountains along the western edge of the Plateau and are underlain by the conglomerate of the Puye Formation (see Fig. 3, conglomerate) in the centrai and eastern edge along the Rio Grande. Chino Mesa basalts (see Fig. 3, basalt) interfinger with the conglomerate along the river. These formations overlie the siltstone/sandstone Tesuque Formation (see Fig. 3 , sediments), which extends across the Rio Grande valley and is in excess of $1000 \mathrm{~m}(3300 \mathrm{ft})$ thick.

Los Alamos area surface water is primarily intermittent stream flow. Springs on flanks of the jemez Mountains supply base flow to upper reaches of some canyons, but the amount is insufficient to maintain surface flows across Laboratory area before it is depleted by evaporation, transpiration, and infiltration. Runoff from heavy thunderstorms or heavy snowmelt reaches the Rio Grande several times a year. Effluents from sanitary sewage, industrial waste treatment plants, and cooling tower blowdown are released to some canyons at rates sufficient to maintain surface flows for as long as about $1.5 \mathrm{~km}(1 \mathrm{mi})$. 


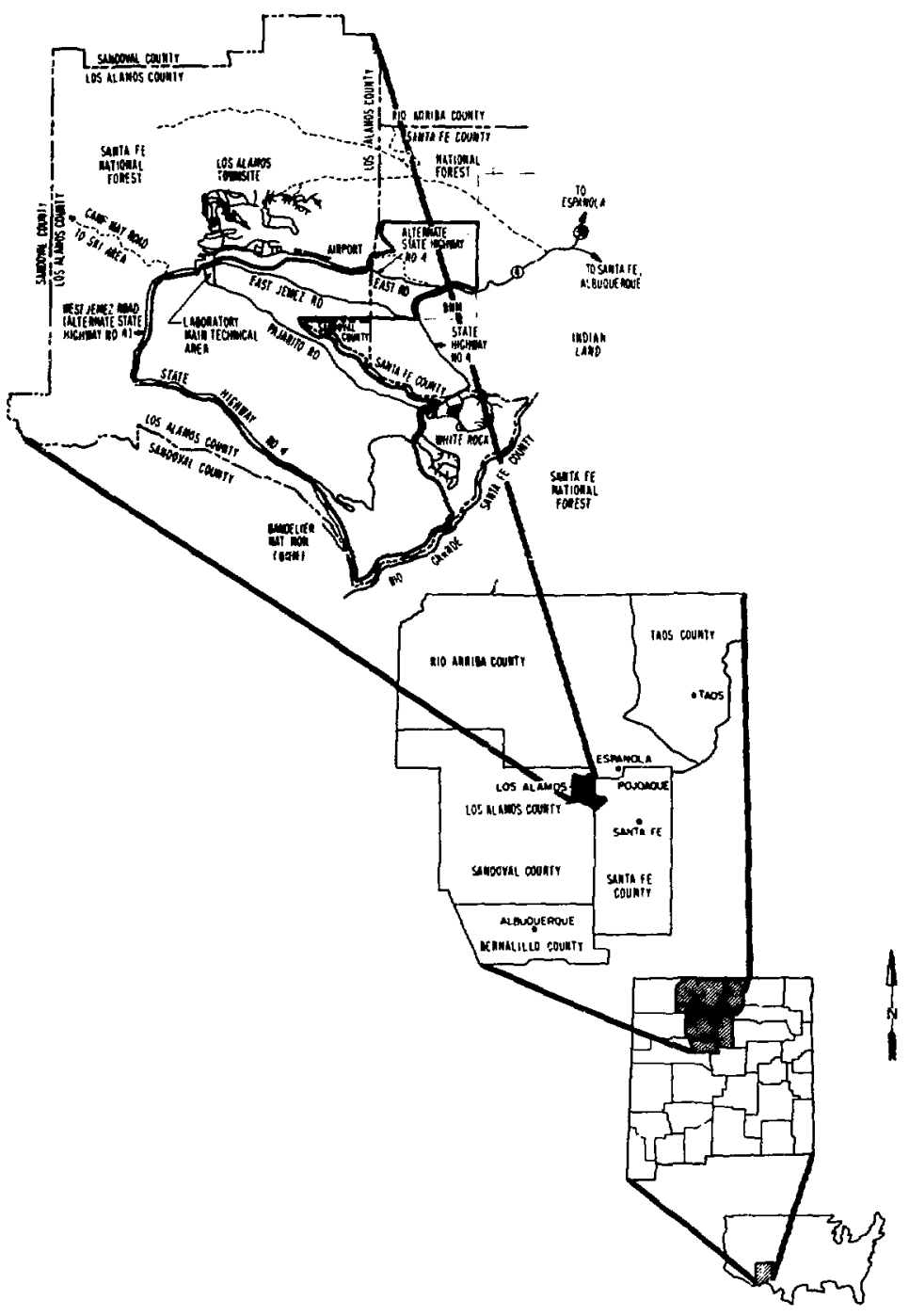

Fig. 2.

Regional location of Los Alamos.

Ground water occurs in three modes in the Los Alamos area: (1) water in shallow alluvium in canyons, (2) perched water, and (3) the main aquifer of the Los Alamos area (see Fig. 3, alluvium, perched water, and main aquifer, respectively).

Intermittent stream flows in canyons of the Plateau have deposited alluvium that ranges from less than $1 \mathrm{~m}(3 \mathrm{ft})$ to as much as $30 \mathrm{~m}(100 \mathrm{ft})$ in thickness. The alluvium is quite permeable in contrast to the underlying volcanic tuff and sediments. Intermittent runoff in canyons infiltrates alluvium until its downward movement is impeded by the less permeable tuff and volcanic sediment. This results in a shallow alluvial ground water body that moves downgradient in the alluvium. As water in the alluvium moves downgradient, it is depleted by evapotranspiration and movement into underlying volcanics.'

Perched water occurs in one limited area about 40 $m$ (120 ft) beneath the mid-reach of Pueblo Canyon and in a second area about 50 to $70 \mathrm{~m}$ (160 to $200 \mathrm{ft}$ ) baneath the surface in lower Pueblo and Loo Alamos 
LOS ALAMOS, NM

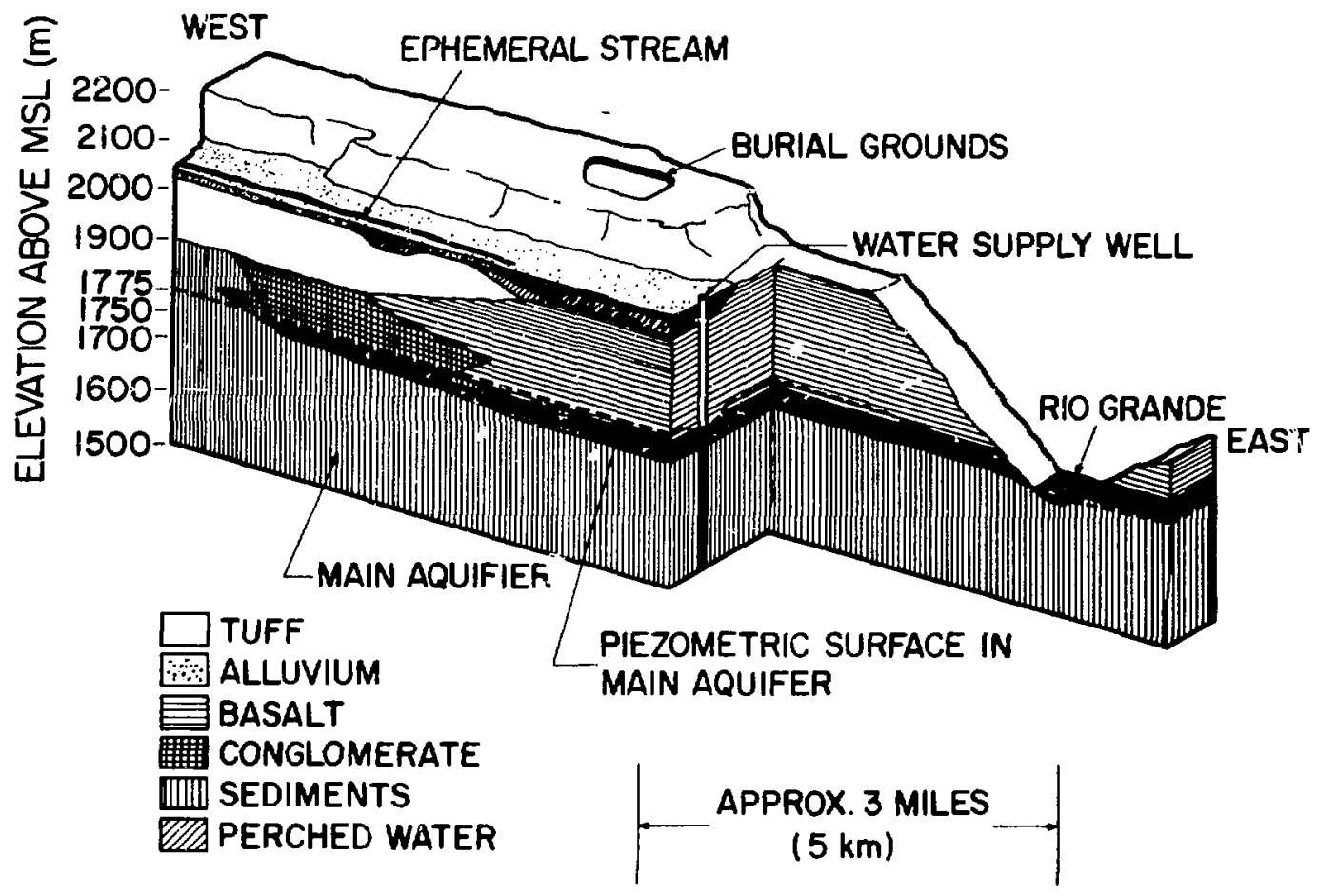

Fig. 3.

Conceptual illustration of geologic-hydrologic relationships in the Los Alamos area.

Canyons near their confluence. The second area is mainly in the basalts (see Fig. 3, perched water and basalt) and has one discharge point at Basalt Springs in Los Alamos Canyon. Perched water bodies are formed by water infiltrating from canyon alluvium into underlying volcanics until it reaches an impermeable layer that prevents further downward movement.

The main aquifer of the Los Alamos area is the only aquifer in the area capable of serving as a municipal water supply. The surface of the aquifer rises westward from the Rio Grande within the Tesuque Formation into the lower part of the Puye Formation beneath the central and western part of the Plateau. Depth to the aquifer decreases from $360 \mathrm{~m}$ $(1200 \mathrm{ft}$ ) along the western margin of the Plateau to about $180 \mathrm{~m}(600 \mathrm{ft})$ at the eastern margin. The main aquifer is isolated from alluvial water and perched water by about 110 to $190 \mathrm{~m}$ (350 to $620 \mathrm{ft}$ ) of dry tuff and volcanic sediments. Thus there is no hydrologic connection or potential for recharge to the main aquifer from alluvial or perched water.

Water in the main aquifer is under table conditions in the western and central part of the Plateau and under artesian conditions in the eastern part and along the Rio Grande. ${ }^{2}$ The major recharg,e area to the main aquifer is the intermountain basin of the Valles Caldera in the Jemez Mountains west of Los Alamos (see Fig. 1 and inside front cover). The water table in the caldera is near land surface. The underlying lake sediment and volcanics are highly permeable and recharge the aquifer through Tschicoma Formation interflow breccias and the Tesuque Formation. The Rio Grande receives ground water discharge from springs fed by the main aquifer. The $18.4 \mathrm{~km}(11.5 \mathrm{mi})$ reach of the river in White Rock Canyon between Otowi Bridge and the mouth of Rito de Frijoles receives an estimated $\mathbf{5 . 3}$ 
to $6.8 \times 10^{\circ} \mathrm{m}^{\circ}$ (4300 to 5500 acre-feet) annually from the aquifer.

\section{Climatology}

Los Alamos has a semiarid, continental mountain climate. The average annual precipitation of $46 \mathrm{~cm}$ (19 in) is accounted for by warm-season convective rain showers and winter migratory storms. Seventyfive per cent of the annual total moisture falls between May and October, primarily during thunderstorms. Peak shower activity is in August. Winter precipitation falls primarily as snow, with annual accumulations of about $1.3 \mathrm{~m}(4.3 \mathrm{ft})$.

Summers are cool and pleasant. Maximum temperatures are generally below $32^{\circ} \mathrm{C}\left(90^{\circ} \mathrm{F}\right)$ and a large diurnal variation keeps nocturnal temperatures in the 12 to $15^{\circ} \mathrm{C}\left(54\right.$ to $\left.59^{\circ} \mathrm{F}\right)$ range. Winter temperatures are typically in the range from $-10^{\circ} \mathrm{C}$ to $5^{\circ} \mathrm{C}\left(14\right.$ to $\left.41^{\circ} \mathrm{F}\right)$. Many winter days are clear with light winds, and strong solar radiation makes conditions quite comfortable even when air temperatures are cold. A summary of average and 1979 weather data is presented in Fig. 4 and Table E-I.

Major spetial variation of surface winds in Los Alamos is caused by the unusual terrain. Under moderate and strong atmospheric pressure differences, flow is channeled by the major terrain features. Under weak pressure differences, a distinct daily wind cycle exists. Interaction of these two patterns gives rise to a westerly flow predominance on the western part of the Laboratory site and a southerly component at the east end of the mesas.

Historically, no tornadoes have been reported in Los Alamos County. Lightning, however, is common in the vicinity of Pajarito Plateau. Local climatological records indicate an average of 62 thunderstorm-days per year. Lightning protection is an important consideration applied to each facility at LASL.

\section{Population Distribution}

Los Alamos County has a population estimated at 19600 . Two residential and related commercial areas exist in the county (see Fig. 5 and inside back cover). The Los Alamos Townsite, the original area of development (and now including residential areas known as the Eastern Area, the Westem Area, North
Community, Barrance Mesa, and North Mesa), has an estimated population of $133 \mathrm{CO}$. The White Rock Area (including residential areas known as White Rock, La Senda, and Pajarito Acres) has about 6500 residents. Commuting and general traffic are served by State Road 4 (SR-4), which runs through White Rock, and Loop 4, which runs through Los Alamos (see Fig. 4). Two federally owned roads, East Jemez and Pajarito Roads, cross the Laboratory site and are normally open to public use. About one third of those employed in Los Alamcs commute from other counties. Population estimates for 1979 place 108000 people within an $80 \mathrm{~km}(50 \mathrm{mi})$ radius of Los Alamos.

\section{B. Los Alamos Scientific Laboratory}

\section{Programs and Facilities}

Since its inception in 1943 , the Laboratory's primary mission has been nuclear weapons research and development. National security programs include weapons development, laser fusion, nuclear materials research, and laser isotope separation, as well as basic research in the areas of physics, chemistry, and engineering that support such programs. Research on peaceful uses of nuclear energy has included space applications, power reactor programs, radiobiology, medicine, and laser and magnetic fusion. In more recent years other programs have been added in applied photochemistry, astrophysics, earth sciences, tnergy resources, nuclear fuel safeguards, lesers, computers, solar energy, geothermal energy, biomedical and environmmental research, and nuclear waste management research.

A unique combination of facilities which contribute to the various research programs exists at Los Alamos. These facilities include an $800 \mathrm{MeV}$ protron accelerator, a tandem Van de Graaff accelerator, a High Energy Gas Laser Facility, a Magnetic Fusion Laboratory, a flash radiographic facility, and an 8 megawatt research reactor. Some of these facilities encourage participation and joint projects by researchers from other laboratories and research facilities.

In August 1977, the LASL site, encompassing 111 $\mathrm{km}^{2}$ (27 500 acres), was dedicated as a National Environmental Research Park. The ultimate goal of the 


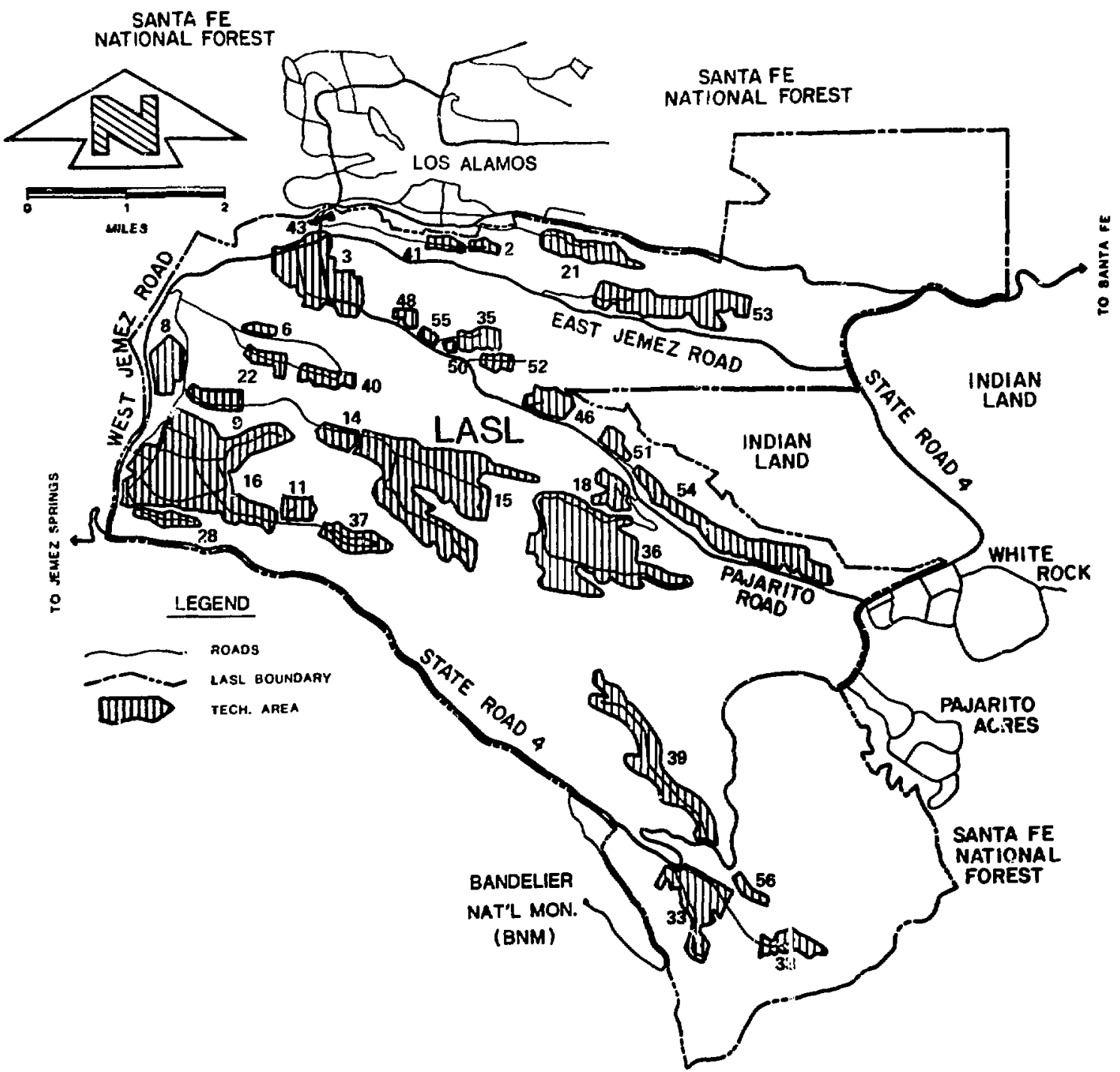

Fig. 4.

LASL technical and adjacent community areas.

programs associated with this regional facility is to encourage environmental research that will contribute understanding of how man can best live in balance with nature while enjoying the benefits of technology. Park resources are made available to individuals and organizations outside of LASL for the purpose of facilitating self-supported research on these subjects deemed compatible with the LASL programi atic mission.

A final environmental impact statement (FEIS) ${ }^{3}$ which assesses potential cumulative environmental in pacts associated with current, known future, and continuing activities at LASL was completed this year. The FEIS provides environmental input for decisions regarding continuing activities at LASL. It iso provides much more detailed information on the environment of Los Alamos area.

The Laboratory is administered by the University of California for DOE, under contract W-7405-ENG36. The LASL environmental program, conducted by the Environmental Surveillance Group, is part of 


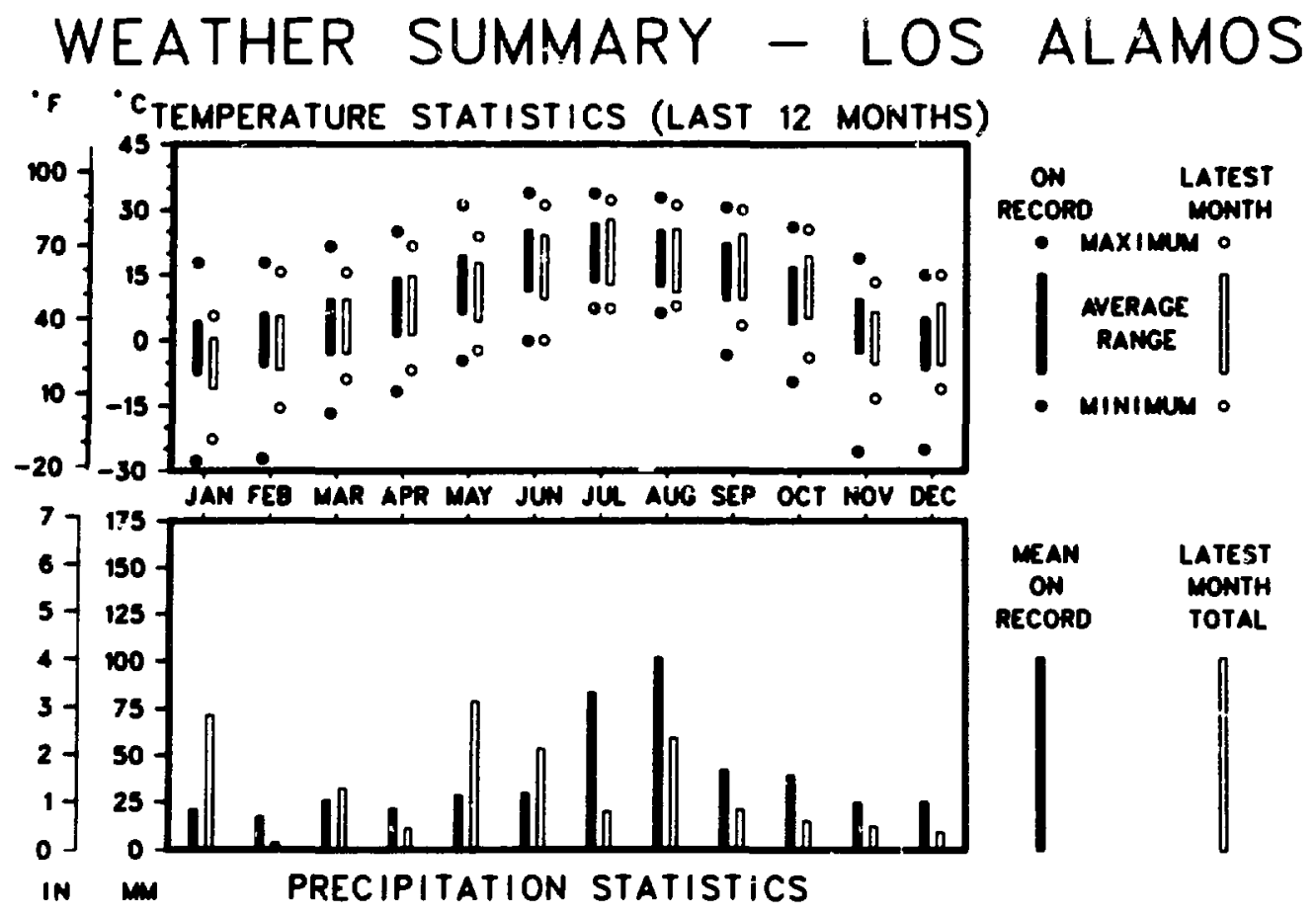

Fig. 5.

Summary of 1979 weather in Los Alamos.

a continuing investigation and documentation program.

\section{Waste Management}

LASL's activities are carried out in 31 active technical areas (TA) distributed over the rite (see Fig. 4). Wastes requiring disposal are generated at virtually all these locations. Sanitary sewage is handled by a number of plants employing conventional secondary treatment processes or by septic tank installations. Uncontaminated solid waste is disposed in a County-operated landfill located within the Laboratory boundary. Nonradioactive airbome effluents include combustion products from the power and steam plants, vapors or fumes from numerous local exhaust systems such as chemistry laboratory hoods, and burning of high explosives wastes.

Most liquid radioactive or chemical laboratory waste is routed to one of two waste treatment facilities by a collection system that is independent from the sanitary sewage system. The balance of such wastes from re ste locations is accumulated in holding tanks ad periodically collected and transported to the treatment plants for processing. Radiuactivity is removed at the treatment plants by physiochemical processes that produce a concentrated sludge subsequently handled as solid radioactive waste. The treated effluents are released to canyons.

Between $90 \%$ and $95 \%$ of the total volume of radioactively contaminated solid waste from the Laboratory is disposed of by burial at the waste disposal area, TA-54. The remaining 5-10\% is classed as tranuranic waste and stored retrievably. Environmental containment is provided by the dry geologic formation of the burial ground.

Airborne radioactive effluents are discharged from a number of facilities after receiving appropriate treatment such as filtration for particulates, catalytic conversion and adsorption of tritium, or storage to permit decay of short-lived activation gases. 


\section{MONITORING RFSULTS}

\section{A. Radiation and Radioactivity}

\section{Penetrating Radiation}

Levels of penetrating radiation, including $x$ and gamma rays from cosmic, terrestrial, and man-made sources in the Los Alamos area are monitored with thermoluminescent dosimeters deployed in two independent networks. The environmental network consists of 31 locations divided into three groups (Fig. 6). Three of these locations are 28 to $44 \mathrm{~km}$ from the Laboratory boundaries in the neighboring communities of Española, Pojoaque, and Santa Fe, and form the regional grovp (Fig. 7). The perimeter group consists of 12 dosimeters placed within $\mathbf{4} \mathbf{k m}$ of the bo ndary. Sixteen locations within LASL boundaries are classed as the onsite group. The dosimeters are changed each calendar quarter. The second network consists of 24 locations, all within LASL boundaries. This network was established to monitor radioactivity of the gaseous effluent from the Los Alamos Meson Physics Facility (LAMPF) at ground level approximately $1 \mathrm{~km}$ from the stack. Twelve of the 24 locations are along an $800 \mathrm{~m}$ segment of the LASL boundary directly north of LAMPF. The dosimeters are changed in accordance with the operating schedule of LAMPF. No measurements at regional or perimeter locations in the environmental network for any calendar quarter showed any statistically discernible increase in radiation levels that could be attributed to LASL operations; onsite measurements were slightly above background levels, reflecting research activities at LASL. The LAMPF network showed an increase of $21.7 \pm 2.2 \mathrm{mrem} / \mathrm{yr}$ at the LASL boundary north of the LAMPF facility. Tables II and E-II summarize the annual total doses by the regional, perimeter, and onsite groups for 1979 . Figure 8 shows a comparison of dose averages for the last four years.

Natural penetrating radiation background has two components. The natural terrestrial component results from the decay of ${ }^{40} \mathrm{~K}$ and the radioactive daughters from the decay chains of ${ }^{232} \mathrm{Th}$ and ${ }^{280} \mathrm{U}$. The cosmic component includes both photon radiation and neutrons. The thermoluminescent dosimeters (TLDs) used in the LASL monitoring program are insensitive to neutrons so neutron contribution to natural background radiation was not measured and, therefore, will be excluded from this discussion. The cosmic ionizing radiation level increases with elevation because of reduction in the shielding effect of the atmosphere. At sea level it averages between 25 and $30 \mathrm{mrem} / \mathrm{yr}$. Los Alamos, with a mean elevation of about $2.2 \mathrm{~km}$, receives about $60 \mathrm{mrem} / \mathrm{yr}$ from the cosmic component. The regional monitoring locations. ranging from about $1.7 \mathrm{~km}$ elevation at Pojoaque to about $2.1 \mathrm{~km}$ at Santa $\mathrm{Fe}$, receive from $50-60 \mathrm{mrem} / \mathrm{yr}$. $^{*}$

In contrast to this fairly constant cosmic component, the dose from the natural terrestrial compu nent in the Los Alamos area is highly variable. The temporal variation at any particular location (Fig. 8 ) is about $15-25 \%$ because of variations in soil moisture content and snow cover. " Figure 7, which compares all TLD locations that have been unchanged during the last four years, shows this temporal variation in the offsite and perimeter averages. The variation in the onsite averages is more influenced by changes in the research programs at particular LASL sites than by changes in soil moisture or snow cover. There is also spatial variation because of different soil and rock types in the area. These natural sources of variation make it difficult to detect any increases in the radiation level from man-made sources, especially if the magnitude of such an increase is small compared to natural fluctuations.

In order to discriminate between these man-made and natural components of variation, data were used from two different dosimeter configurations at each LAMPF network location. One measures total 


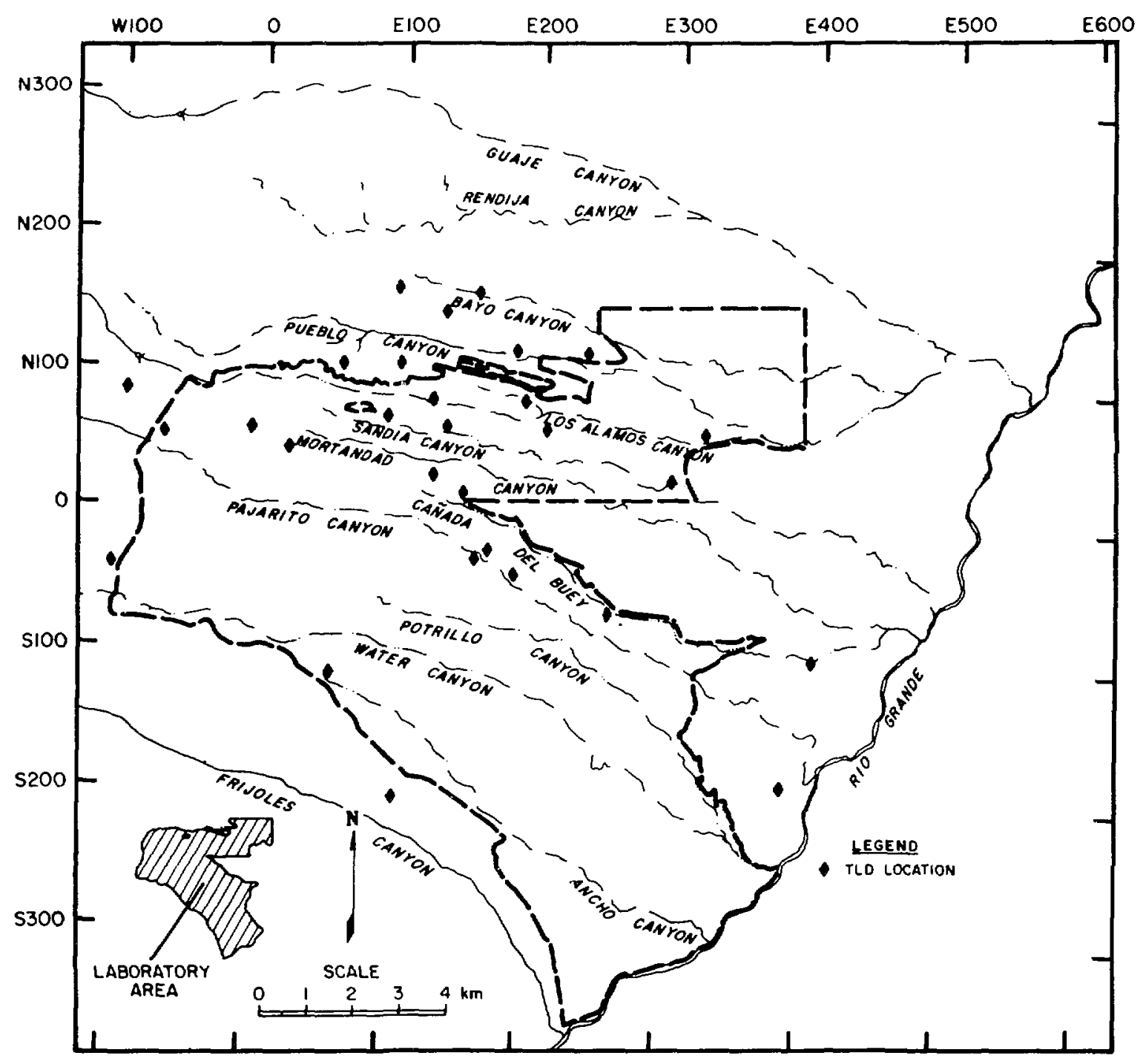

Fig. 6.

TLD locations on or near the LASL Site.

penetrating radiation, both cosmic and terrestrial. The second is shielded from below with enough lead to eliminate about $90 \%$ of the direct terrestrial gamma-ray component and from above by enough Lucite $\odot$ to eliminate virtually all beta particles and positrons (whether from natural sources or from LAMPF operations). Gamma rays from annihilation of positrons and electrons can penetrate the Lucite.

Three of the locations in the LAMPF TLD network are 7.5 to $9 \mathrm{~km}$ from LAMPF in similar terrain. These three locations are not influenced by any laboratory radiation sources and are used as background locations. By comparing ratios of unshielded to shielded doses recorded during the same period at the background locations and at each field location in the LAMPF network, the component of the total penetrating dose due to LAMPF operations can be determined for each field location. 


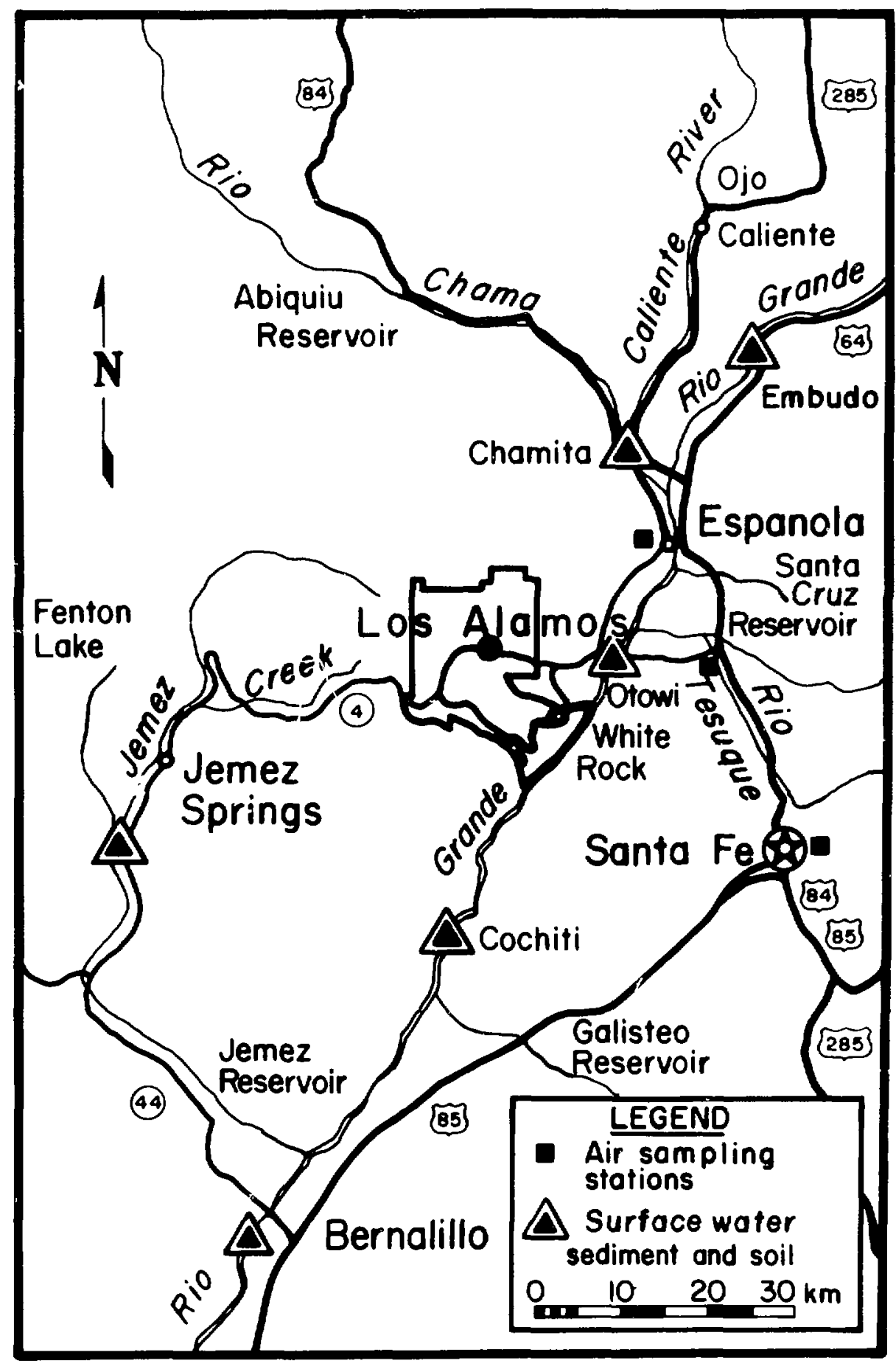

Fig. 7.

Regional surface water, sediments, soil and air sampling locations. 


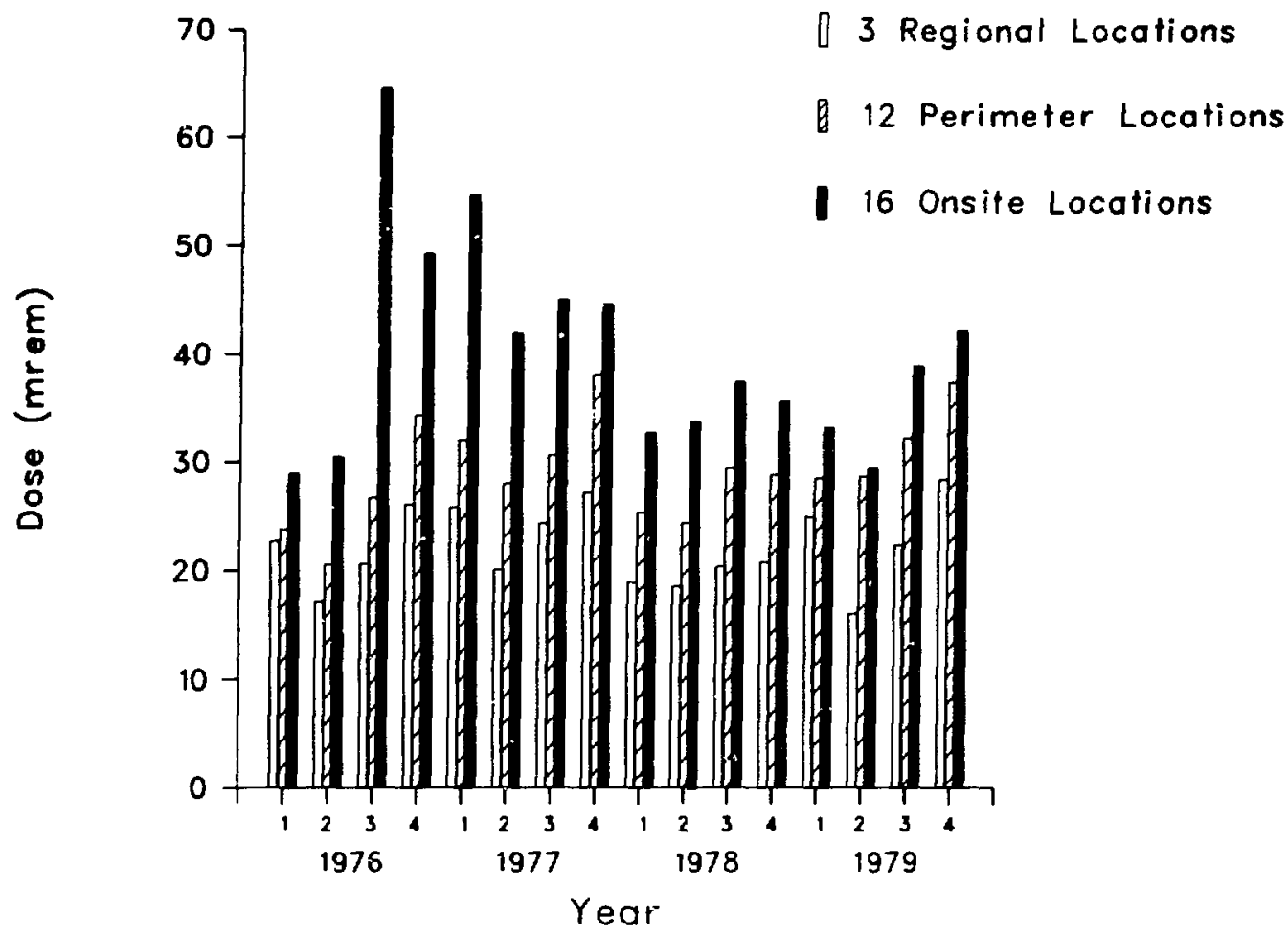

Fig. 8.

Quarterly dose averages for three station groups during the last four years.

\section{Atmospheric Radioactivity}

Worldwide background atmospheric radioactivity is composed of fallout from atmospheric nuclear weapons tests, natural radioactive constituents in dust from the earth's surface, and radioactive materials resulting from interactions with cosmic radiation. Air is routinely sampled at several locations on Laboratory land, along the Laboratory perimeter, and in distant areas to determine the existence and composition of any contributions to radionuclide levels from Laboratory operations. During 1979, no statistically significant difference was observed between atmospheric concentrations of gross alpha, gross beta, americium, plutonium, and uranium measured at sampling locations along the Laboratory perimeter and those measured in distant areas. This indicates Laboratory contributions to concentrations of these contaminants were less than local variability in background levels. Tritiated water vapor concentrations at 4 onsite stations were 5 to 15 times higher than regional background levels and are attributable to LASL operations, whereas concentrations at the other 7 onsite stations were statistically indistinguishable from regional background concentrations. 


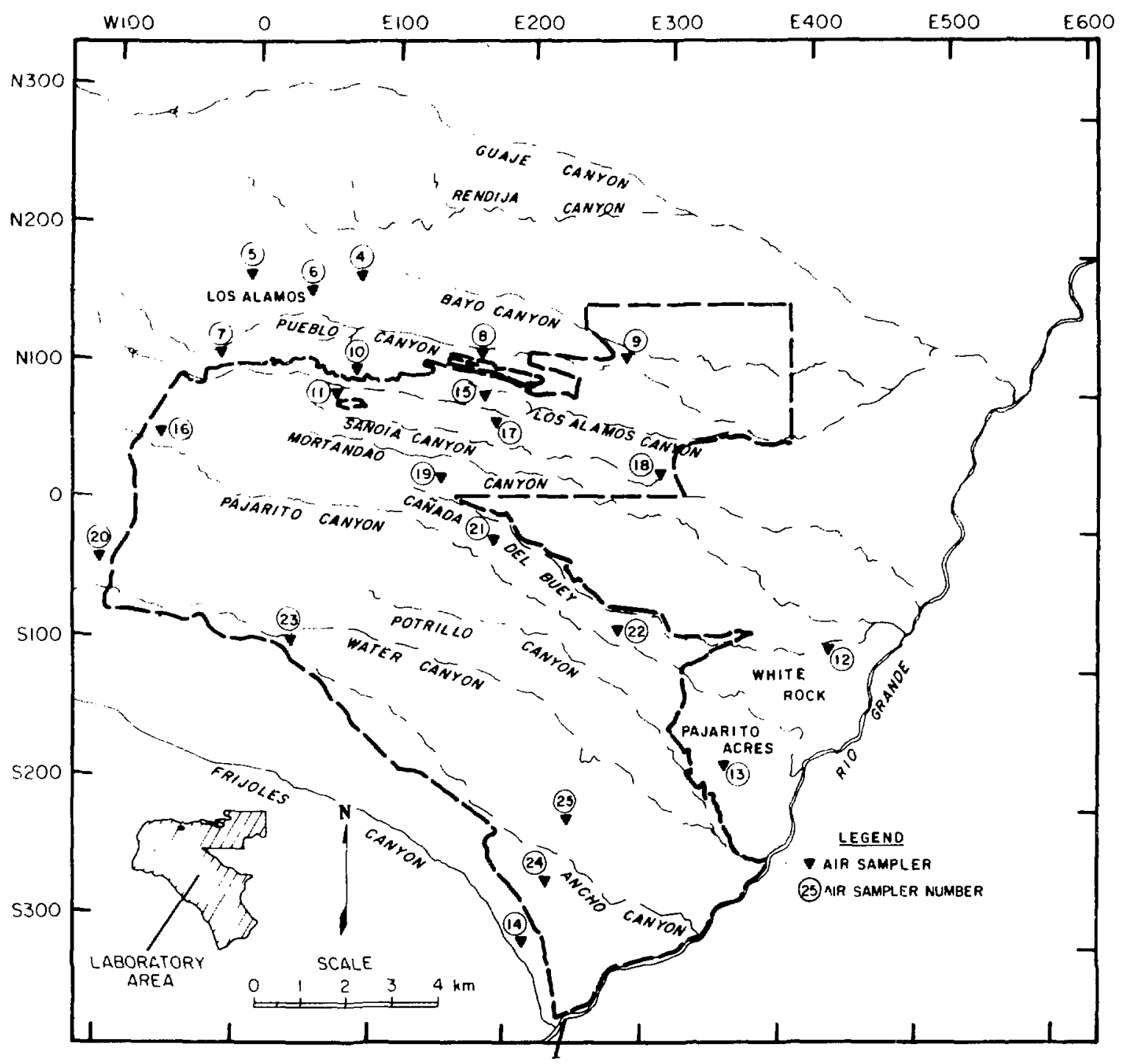

Fig. 9.

Air sampler locations on or near the LASL site.

\section{a. Introduction}

Atmospheric radioactivity samples were collected at 25 continuously operating air sampling stations in Los Alamos County and vicinity. Onsite and perimeter station locations are shown in Fig. 9 and identified by map coordinates in Table E-III. Perimeter stations are within $4 \mathrm{~km}$ of the Laboratory boundary. The regional monitoring stations, located 28 to $44 \mathrm{~km}$ from the Laboratory at Española, Pojoaque, and Santa Fe (Fig. 7), serve as reference points in determining the regional background for atmospheric radioactivity. A complete description of sampling procedures and statistical treatment cf data is given in Appendix B.

When interpreting data from this air sampling program, one must first be aware of natural and fallout radioactivity levels and their fluctuations. Worldwide background atmospheric radioactivity is largely composed of fallout from atmospheric nuclear weapons tests, natural radioactive constituents in dust from the decay chains of ${ }^{2 \times} \mathrm{Th},{ }^{20 \mathrm{U}}$, 
and materials resulting from interactions with cosmic radiation, such as tritiated water vapor. Because suspended particulates are mostly from soil resuspension, there are large temporal fluctuations in radioactivity concentrations as a result of changing metenrological conditions. Periods of high winds, resulting in relatively high suspended palticulate concentrations, contrast with periods of heavy precipitation, which remove much of the suspended mass. Spatial variations may be dependent on these same factors. Previous measurements of background atmospheric radioactivity concentrations are summarized in Table E-IV and are useful in interpreting the air sampling data.

\section{b. Annual Gross Alpha and Gross Beta Radioactivity}

Gross alpha and beta analyses serve as crude indicators of overall radioactivity levels. The annual average 4-wk gross alpha and gross beta concentrations are summarized in Table VI and shown in detail in Table E-V. There was a very slight increase in long-lived gross beta concentrations (see Fig. 10) during the spring. This elevated activity was small this spring in comparison with maxima observed in other years when mixing of the stratosphere with the troposphere causes increased fallout of radioactive particulates.

Data plotted in Fig. 10 also show that there were no significant differences in atmospheric gross beta concentrations among regional, perimeter, and onsite sampling stations this year. There have been no statistically significant differences over the past seven years. This lack of statistically significant differences in concentrations indicates that Laboratory operations have negligible influence on the ambient atmospheric radioactivity in the Los Alamos vicinity and suggests that this radioactivity originates from widespread sources-fallout from nuclear test detonations and naturally occurring materials-and not from a localized source such as the Laboratory.

\section{c. Tritium}

Atmospheric tritiated water concentrations for each station for 1979 are summarized in Table VI, detailed in Table E-VI, and plotted in Fig. 11. The highest annual mean of $40( \pm 42) \mathrm{pCi} / \mathrm{m}^{2}$ at TA-33 is attributable to tritium stack effluents from the site. A total of $10470 \mathrm{Ci}$ of tritium was released from TA33 during the year, about $70 \%$ of the total from all technical areas at LASL (see Table E-XX). The relatively higher concentrations at TA-54 (station 22) result from evapotranspiration of buried tritium-contaminated wastes at this site. Also, tritium effluents from stacks near sampling stations at TA-52 (station 19) and TA-39 (station 25) cause their annual means to be relatively higher than the other stations.

\section{d. Plutonium}

Annual average ${ }^{250} \mathrm{Pu}$ and ${ }^{230} \mathrm{Pu}$ concentrations are summarized in Table VI and detailed in Table EVIl. All ${ }^{2 s a} \mathrm{Pu}$ concentrations, except for one at TA16 (station 20), had no detectable (i.e., where the $2 \mathrm{~s}$ measurement error was less than the ineasured value) values. The annual ${ }^{20} \mathrm{Pu}$ means were lower than last year because of an apparently small input from worldwide fallout (see Fig. 10), although maximum values at several stations were slightly higher than in 1979. These maximum concentrations occurred during the first and third quarters. The maxima during the first quarter could be related to increased ${ }^{230} \mathrm{Pu}$ airborne emissions from one LASL facility, however, the third quarter maxima occurred when releases from that facility were relatively low (see Section III.A.6). Regional, perimeter, and onsite group ${ }^{239} \mathrm{Pu}$ means are statistically indistinguishable from one another, indicating Laboratory contributions of ${ }^{2 s} \mathrm{Pu}$ to the atmosphere are negligible.

\section{e. Uranium and Americium}

The 1979 atmospheric uranium concentrations are summarized in Table VI and listed in Table EVIII. Uranium concentrations are heavily dependent on the immediate environment of the sampling station. Those stations with higher annual averages and maximums were all located in dusty areas where historically a higher filter dust loading has accounted for collection of more natural uranium. Annual station averages are typical of regional background atmospheric uranium concentrations 
TABLE VI

\section{SUMMARY OF ANNUAL ATMOSPHERIC RADIOACTIVITY MONITORING FOR 1979"}

\begin{tabular}{|c|c|c|c|c|c|c|}
\hline Analysis & $\begin{array}{c}\text { Composite } \\
\text { Group }\end{array}$ & Units & $\begin{array}{l}\text { Maximum } \\
\text { Observed }\end{array}$ & $\begin{array}{l}\text { Minimum } \\
\text { Observed }\end{array}$ & $\begin{array}{c}\text { Annual } \\
\text { Mean }\end{array}$ & $\begin{array}{c}\text { Mean As } \\
\% \mathrm{CG} \\
\end{array}$ \\
\hline \multirow[t]{3}{*}{ Gross alpha } & Regional & $10^{-16}{ }_{\mu} \mathrm{Ci} / \mathrm{ml}$ & $5.9 \pm 2.6$ & $0.3 \pm 0.2$ & $1.4 \pm 1.5$ & 1.3 \\
\hline & Perimeter & $10^{-16} \mu \mathrm{Ci} / \mathrm{m} \ell$ & $7.4 \pm 3.2$ & $0.0 \pm 0.1$ & $2.2 \pm 2.8$ & 3.7 \\
\hline & Onsite & $10^{-16} \mu \mathrm{Ci} / \mathrm{m} \ell$ & $6.2 \pm 2.8$ & $0.0 \pm 0.0$ & $2.3 \pm 2.7$ & 0.1 \\
\hline \multirow[t]{3}{*}{ Gross beta } & Regional & $10^{-16} \mu \mathrm{Ci} / \mathrm{ml}$ & $132 \pm 34$ & $8.5 \pm 2.2$ & $25 \pm 17$ & 0.03 \\
\hline & Perimeter & $10^{-16} \mu \mathrm{Ci} / \mathrm{ml}$ & $62 \pm 16$ & $0.0 \pm 0.1$ & $28 \pm 23$ & 0.03 \\
\hline & Onsite & $10^{-16}{ }_{\mu} \mathrm{Ci} / \mathrm{m} \ell$ & $58 \pm 14$ & $0.0 \pm 0.1$ & $29 \pm 26$ & 0.0007 \\
\hline Tritiated & Regional & $10^{-12} \mu \mathrm{Ci} / \mathrm{ml}$ & $20 \pm 10$ & $-1.4 \pm 1$ & $2.7 \pm 8.7$ & 0.001 \\
\hline \multirow[t]{2}{*}{ Water vapor } & Perimeter & $10^{-12} \mu \mathrm{Ci} / \mathrm{ml}$ & $65 \pm 22$ & $0.1 \pm 0.6$ & $4.9 \pm 15$ & 0.002 \\
\hline & Onsite & $10^{-12} \mu \mathrm{Ci} / \mathrm{m} \ell$ & $130 \pm 40$ & $-3.0 \pm 1.2$ & $12 \pm 42$ & 0.0002 \\
\hline \multirow[t]{3}{*}{${ }^{238} \mathrm{Pu}$} & Regional & $10^{-18} \mu \mathrm{Ci} / \mathrm{m} \ell$ & $1.5 \pm 22$ & $-6.2 \pm 4.5$ & $-2.6 \pm 3.2$ & 0.0 \\
\hline & Perimeter & $10^{-18} \mu \mathrm{Ci} / \mathrm{m} \ell$ & $1.6 \pm 2.9$ & $-14 \pm 15$ & $-2.3 \pm 2.9$ & 0.0 \\
\hline & Onsite & $10^{-18} \mu \mathrm{Ci} / \mathrm{m} \ell$ & $20 \pm 6.9$ & $-8 \pm 5$ & $-2.1 \pm 3.8$ & 0.0 \\
\hline \multirow[t]{3}{*}{${ }^{239} \mathrm{Pu}$} & Regional & $10^{-10} \mu \mathrm{Ci} / \mathrm{m} \ell$ & $25 \pm 4.8$ & $-0.9 \pm 1.8$ & $5 \pm 15$ & 0.008 \\
\hline & Perimeter & $10^{-10} \mu \mathrm{Ci} / \mathrm{m} \ell$ & $83 \pm 11$ & $-7 \pm 25$ & $8.1 \pm 30$ & 0.013 \\
\hline & Onsite & $10^{-18} \mu \mathrm{Ci} / \mathrm{m} \ell$ & $242 \pm 20$ & $-1.8 \pm 2.5$ & $8.3 \pm 33$ & 0.0004 \\
\hline \multirow[t]{3}{*}{${ }^{241} \mathrm{Am}$} & Regional & $10^{-18} \mu \mathrm{Ci} / \mathrm{m} \ell$ & $-1.1 \pm 4.6$ & $-6 \pm 10$ & $-3.1 \pm 4.7$ & 0.0 \\
\hline & Perimeter & $10^{-18} \mu \mathrm{Ci} / \mathrm{m} \ell$ & $1.2 \pm 6.8$ & $-4.6 \pm 5.2$ & $-1 \pm 2.6$ & 0.0 \\
\hline & Onsite & $10^{-16} \mu \mathrm{Ci} / \mathrm{m} \ell$ & $37 \pm 10$ & $-5.1 \pm 7.6$ & $-0.1 \pm 9.4$ & 0.0 \\
\hline Total & Regional & $\mathrm{pg} / \mathrm{m}^{\mathrm{s}}$ & $116 \pm 18$ & $15 \pm 17$ & $62 \pm 75$ & 0.0007 \\
\hline \multirow[t]{2}{*}{ Uranium } & Perimeter & $\mathrm{pg} / \mathrm{m}^{\mathrm{s}}$ & $190 \pm 32$ & $8 \pm 21$ & $54 \pm 73$ & 0.0006 \\
\hline & Onsite & $\mathrm{pg} / \mathrm{m}^{\mathrm{s}}$ & $251 \pm 55$ & $-1.8 \pm 18$ & $50 \pm 64$ & 0.00002 \\
\hline
\end{tabular}

aSee footnotes in Table E-V (gross alpha and beta), E-VI (tritiated water vapor), E-VII ( ${ }^{239} \mathrm{Pu}$ and ${ }^{297} \mathrm{Pu}$ ), E-VIII (uranium), and E-IX $\left({ }^{211} \mathrm{Am}\right)$ for minimum detectable limits, Concentration (ruide values, and other pertinent information.

(see Table E-IV). There were no statistically significant (at a $>99 \%$ confidence level) temporal or geographical differences among regional, perimeter, and onsite station groups.

The 1979 atmospheric ${ }^{241} \mathrm{Am}$ concentrations are summarized in Table II and listed in Table E-IX.
Just one quarterly sample $\left(37 \pm 10 \mathrm{aCi} / \mathrm{m}^{\prime}\right.$ at station 22, TA-54) was above the analytical detection limit. Only $0.019 \mu \mathrm{Ci}$ of ${ }^{241} \mathrm{Am}$ was released to the atmosphere from LASL during 1979. 


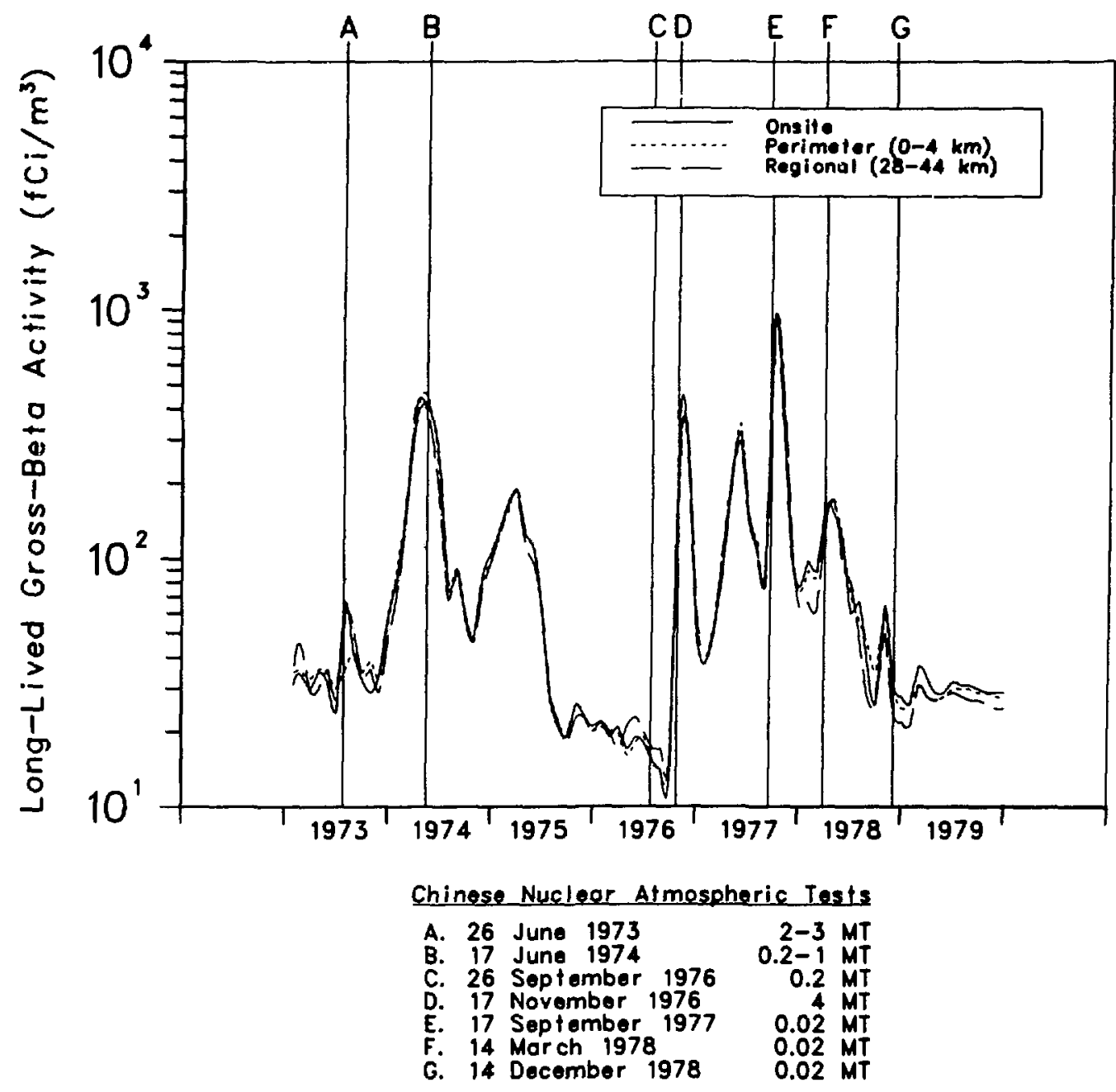

Fig. 10.

Monthly average long-lived gross beta activity in air, 1973 to 1979 , by sampling station groups. 


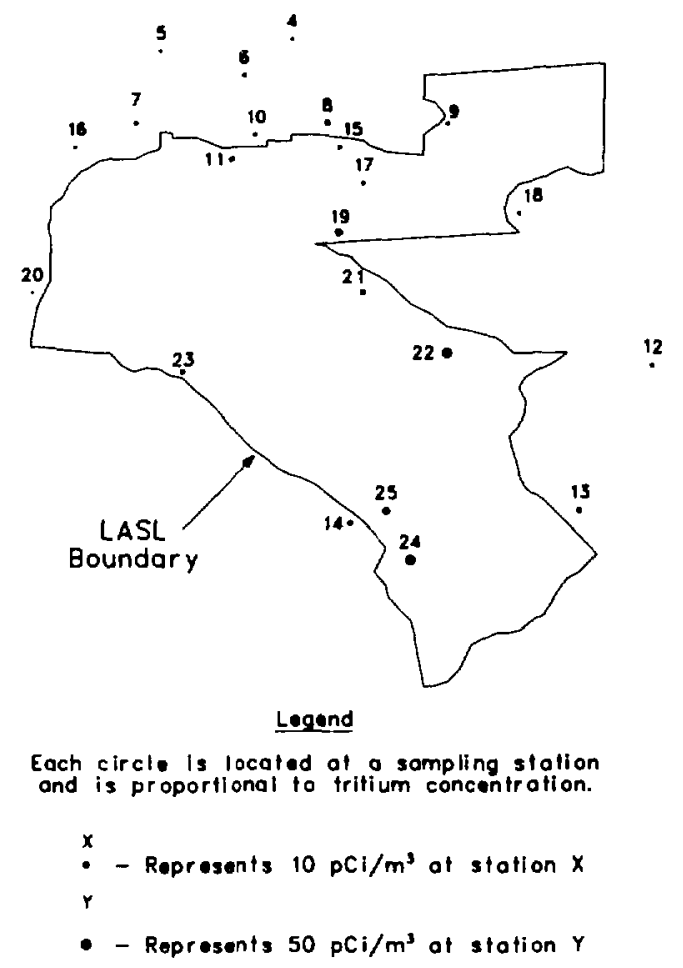

Fig. 11 .

Annual mean atmospheric tritiated water vapor concentrations on or near the LASL site.

\section{Radioactivity in Surface and Ground Waters}

Surface and ground waters are monitored to provide routine surveillance of potential dispersion of radionuclides from LASL operations. Results of these analyses are compared to CGs (see Appendix A) and regional background concentrations as an indication of the small amounts of radionuclides in the environment. Results of 1979 radiochemical quality analyses of water from regional, perimeter, water supply, and onsite noneffluent release areas indicate no significant effect from effluent releases from LASL. Waters in onsite liquid effluent release areas contain trace amounts of radioactivity. These onsite waters are not a source of industrial, agricultural, or municipal water supplies.

a. Regional and Perimeter Waters. Analyses of surface and ground waters from regional and perimeter stations reflect base line levels of radioactivity in the areas outside the LASL boundaries. Regional surface waters were collected within $75 \mathrm{~km}$ of LASL from six stations on the Rio Grande, Rio
Chama, and Jemez River (Fig. 7, Table E-X). Samples were also collected from five perimeter stations located within about $4 \mathrm{~km}$ of the LASL boundaries and from 23 stations in White Rock Canyon of the Rio Grande (Fig. 12, Table E-X). Excluded from this discussion is Acid-Pueblo Canyon, a former 


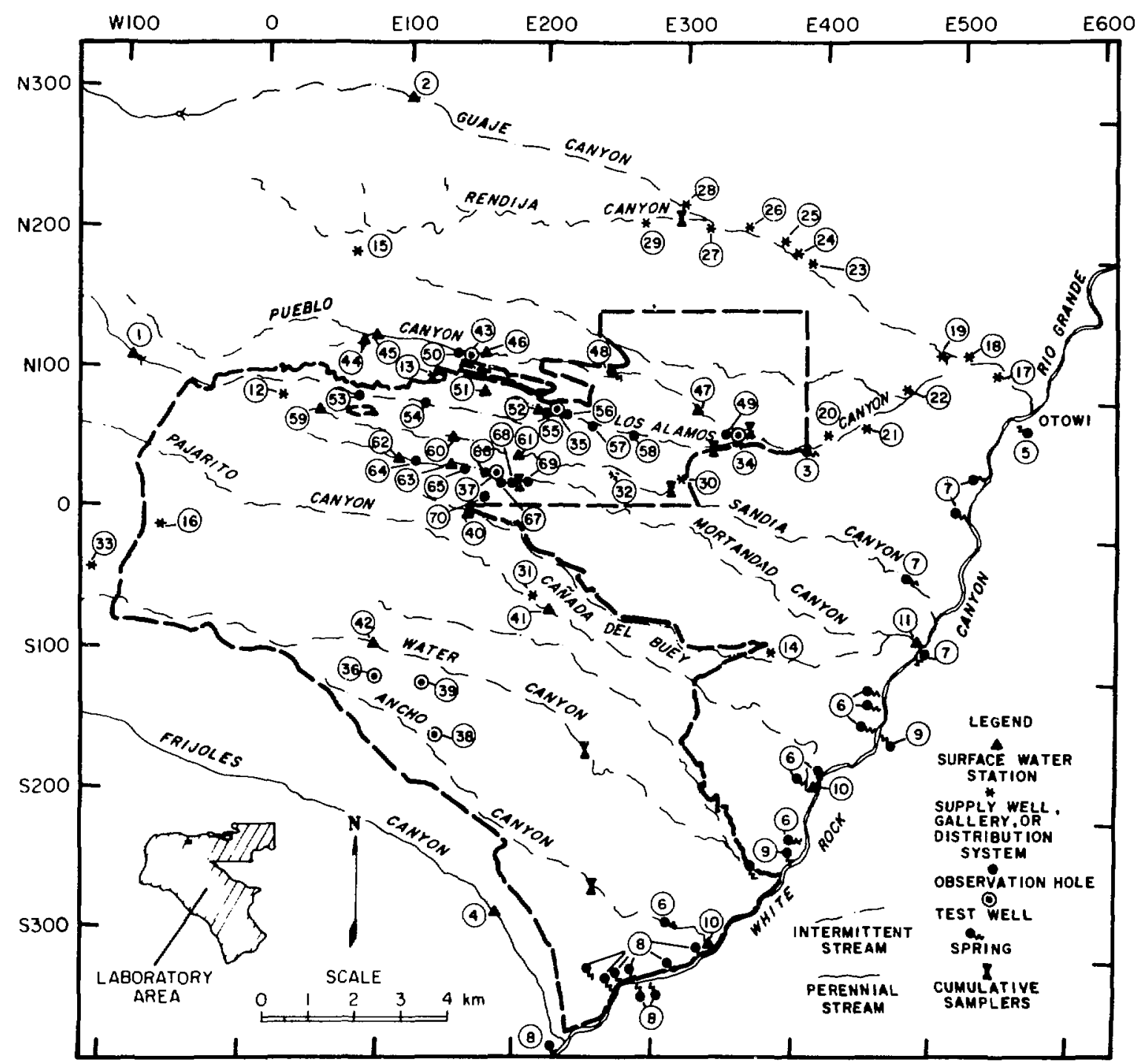

Fig. 12.

Surface and ground water sampling locations on or near the LASL site.

release area for industrial liquid waste, which has four offsite stations and three onsite stations (Fig. 12). As a known release area and for hydrologic continuity, all of the monitoring results in Acid-Pueblo Canyon are discussed in the following section concerning onsite surface and ground waters. Detailed data from regional and perimeter stations are in Table E-XI and E-XII, respectively (see Appendix B.3 for methods of collection, analyses, and reporting of water data). A comparison of the max- imum concentrations found in these waters with CGs for uncontrolled areas is given in Table VII. However, the CGs do not account for concentration mechanisms that may exist in environmental media. Consequently, other media such as sediments, soils, and foods are monitored (as discussed in subsequent sections).

Radionuclide concentrations in surface and ground waters from the six regional and five perimeter stations are low and have shown no effect 


\section{MAXIMUM RADIOACTIVITY CONCENTRATIONS IN REGIONAL AND PERIMETER WATERS}

\begin{tabular}{|c|c|c|c|c|c|}
\hline \multirow[b]{2}{*}{ Analysis } & \multirow[b]{2}{*}{$\begin{array}{c}\text { Units } \\
(\mu \mathrm{Ci} / \mathrm{m} \ell)\end{array}$} & \multirow[b]{2}{*}{ Regional } & \multicolumn{2}{|c|}{ Perimeter } & \multirow{2}{*}{$\begin{array}{c}\text { CG for } \\
\text { Uncontrolled } \\
\text { Areas } \\
\end{array}$} \\
\hline & & & $\begin{array}{c}\text { Five } \\
\text { Stations }\end{array}$ & $\begin{array}{c}\text { White Rock } \\
\text { Canyon }\end{array}$ & \\
\hline${ }^{3} \mathrm{H}$ & $10^{-6}$ & 1.2 & 0.8 & 0.7 & 3000 \\
\hline${ }^{137} \mathrm{Cs}$ & $10^{-\theta}$ & $<120$ & $<60$ & 110 & 30000 \\
\hline${ }^{288} \mathrm{Pu}$ & $10^{-0}$ & $<0.02$ & $<0.07$ & $<0.26$ & 5000 \\
\hline${ }^{239} \mathrm{Pu}$ & $10^{-8}$ & $<0.04$ & $<0.08$ & $<0.06$ & 5000 \\
\hline Gross alpha & $10^{-\bullet}$ & 5 & 5.8 & 4.9 & 5000 \\
\hline Gross beta & $10^{-9}$ & 16 & 8.9 & 16 & 300 \\
\hline Total U & $\mu \mathrm{g} / \ell$ & 5.1 & 14 & 23 & 1800 \\
\hline
\end{tabular}

Note: < value represents analytical value plus twice the uncertainty term for that analysis.

from release of liquid effluents at LASL. Plutonium concentrations are near detection and are well below CGs for uncontrolled areas.

b. Water Supply. The municipal and industrial water supply for the Laboratory and community is from 15 deep wells (in 3 well fields) and one gallery (underground collection basin for spring discharge). The wells are located on Pajarito Plateau and in canyons east of the Laboratory (Fig. 12). The water is pumped from the main aquifer, which lies at a depth of about $350 \mathrm{~m}$ below the surface of the plateau. The gallery discharges from a perched water zone in the volcanics west of the plateau. During 1979 , production from the wells and gallery was about $5.5 \times 10^{6} \mathrm{~m}^{8}$, with the wells furnishing about $97 \%$ of the total production and the gallery about $3 \%$. Water samples were collected from the wells and gallery and at 5 stations on the distribution system. The 5 stations on the distribution system are located within the Laboratory and community (Fig. 12, Table E-X).

Detailed radiochemical analyses from the wells, gallery, and distribution system are presented in Table E-XIII. A comparison of maximum concentrations found in these waters with the EPA
National Interim Primary Drinking Water Standards ${ }^{\circ}$ is given in Table VIII.

Radioactivity occurring in the water supply is low and naturally occurring. Plutonium is below detection limits. Samples from the water distribution system showed gross alpha activity lower than the EPA screening limit (see Appendix A) even though one well (LA-1B, Los Alamos field) contained natural alpha activity about $80 \%$ greater than the screening limit. Dilution by water from the wells results ir, concentrations at points of use (distribution sysien that meet the EPAs criteria for municipal supply.

c. Onsite Surface and Ground Waters. Onsite sampling stations are grouped according to areas that are not located in effluent release areas and those located in areas that receive or have received industrial liquid effluents. Sampling locations in onsite noneffluent release areas consist of seven test wells completed into the main aquifer, and three surface water sources (Fig. 12; Table E-X). Detailed radiochemical analyses are shown in Table E-XIV. The maximum concentration of radioactivity at the ten stations is in Table IX. The concentrations were 
TABLE VIII

\section{MAXIMUM RADIOACTIVITY CONCENTRATIONS IN WATER SUPPLY}

\begin{tabular}{|c|c|c|c|c|}
\hline Analysis & $\begin{array}{c}\text { Units } \\
(\mu \mathrm{Ci} / \mathrm{m} \ell)\end{array}$ & $\begin{array}{c}\text { Wells and } \\
\text { Gallery }\end{array}$ & $\begin{array}{c}\text { Distribution } \\
\text { System }\end{array}$ & $\begin{array}{c}\text { EPA } \\
\text { NIPDWR }\end{array}$ \\
\hline${ }^{9} \mathrm{H}$ & $10^{-\bullet}$ & 0.8 & 1.0 & 20 \\
\hline${ }^{197} \mathrm{Cs}$ & $10^{-9}$ & $<100$ & $<90$ & 200 \\
\hline${ }^{208} \mathrm{Pu}$ & $10^{-e}$ & $<0.04$ & $<0.03$ & 7.5 \\
\hline${ }^{28} \mathrm{Pu}$ & $10^{-}$ & $<0.02$ & $<0.04$ & 7.5 \\
\hline Gross alpha & $10^{-0}$ & 9.0 & 1.2 & 5 \\
\hline Gross beta & $10^{-9}$ & 5.8 & 5.5 & ... \\
\hline Total U & $\mu \mathrm{g} / \ell$ & 6.2 & 3.3 & 1800 \\
\hline
\end{tabular}

-Environmental Protection Agency's National Interim Primary Drinking Water Regulations.

Note: < value represents analytical value plus twice the uncertainty term for that analysis.

TABLE IX

\section{MAXIMUM RADIOACTIVITY CONCENTRATIONS IN ONSITE WATER IN AREAS NOT RECEIVING EFFLUENTS}

\begin{tabular}{|c|c|c|c|}
\hline Analysis & $\underset{(\mu \mathrm{Ci} / \mathrm{m} \ell)}{\text { Units }}$ & $\begin{array}{c}\text { Onsite Non- } \\
\text { Effluent Areas }\end{array}$ & $\begin{array}{c}\text { CG for } \\
\text { Controlled Areas }\end{array}$ \\
\hline${ }^{3} \mathrm{H}$ & $10^{-6}$ & 3.3 & 100000 \\
\hline${ }^{197} \mathrm{Cs}$ & $10^{-9}$ & $<100$ & 400000 \\
\hline${ }^{208} \mathrm{Pu}$ & $10^{-\bullet}$ & $<0.07$ & 100000 \\
\hline${ }^{239} \mathrm{Pu}$ & $10^{-\theta}$ & $<0.08$ & 100000 \\
\hline Gross alpha & $10^{-9}$ & 2.3 & 100000 \\
\hline Gross beta & $10^{-9}$ & 16 & 10000 \\
\hline Total U & $\mu \mathrm{g} / \ell$ & 2.3 & 60000 \\
\hline
\end{tabular}

Note: < value represents analytical value plus twice the uncertainty term for that analysis.

low, near or below detection limits, and well below CGs for controlled areas.

Canyons that receive or have received industrial effluents are Acid-Pueblo, DP-Los Alamos, Sandia, and Mortandad. Samples were collected from surface water stations or shallow observation holes completed in the alluvium. (Fig. 12, Table E-XIV).
The maximum concentration of radioactivity in each of the four canyons is given in Table $X$. Radioactivity observed in Acid-Pueblo Canyon (7 stations) results from residuals of treated and untreated radioactive liquid waste effluents released into the canyon before 1964 (Table E-XIV). 
TABLE X

\section{MAXIMUM RADIOACTIVITY CONCENTRATIONS IN WATERS IN AREAS RECEIVING EFFLUENTS}

\begin{tabular}{|c|c|c|c|c|c|c|}
\hline Analysis & $\begin{array}{c}\text { Units } \\
(\mu \mathrm{Ci} / \mathrm{m} \ell)\end{array}$ & $\begin{array}{l}\text { Acid- } \\
\text { Pueblo }\end{array}$ & $\begin{array}{c}\text { DP-Los } \\
\text { Alamos }\end{array}$ & Sandia & Mortandad & $\begin{array}{c}\text { CG for } \\
\text { Controlled Areas } \\
\end{array}$ \\
\hline${ }^{3} \mathrm{H}$ & $10^{-6}$ & 20 & 11 & 7.5 & 650 & 100000 \\
\hline${ }^{237} \mathrm{Cs}$ & $10^{-\bullet}$ & $<100$ & $<110$ & 27 & 210 & 400000 \\
\hline${ }^{238} \mathrm{Pu}$ & $10^{-9}$ & $<0.05$ & 0.11 & 0.07 & 4.6 & 100000 \\
\hline${ }^{290} \mathrm{Pu}$ & $10^{-\bullet}$ & 0.50 & 0.64 & $<0.03$ & 2.5 & 100000 \\
\hline${ }^{241} \mathrm{Am}$ & $10^{-\infty}$ & $\ldots$ & 7.6 & $<0.11$ & 5.6 & 100000 \\
\hline Gross aipha & $10^{-\theta}$ & 2.6 & 30 & $<1.5$ & 46 & 100000 \\
\hline Gross beta & $10^{-\theta}$ & 97 & 380 & 26 & 340 & 10000 \\
\hline Total U & $\mu \mathrm{g} / \ell$ & 3.0 & 77 & 2.0 & 4.3 & 60000 \\
\hline
\end{tabular}

Note: < value represents analytical value plus twice the uncertainty term for that analysis.

Radionuclides that were adsorbed by channel sediments are now being resuspended by runoff and municipal sanitary effluents.

Sandia Canyon ( 3 stations) receives cooling tower blowdown from the TA-3 power plant and some sanitary effluent from the TA-3 areas. Analyses of samples from this canyon show ${ }^{137} \mathrm{Cs}$ and ${ }^{208} \mathrm{Pu}$ at detection limits, in one sample (Table E-XIV).

DP-Los Alamos Canyon (8 stations) receives industrial effluents that contain low levels of radionuclides and some sanitary effluents from $T A_{2}$. 21. Mortandad Canyon ( 8 stations) receives treated industrial effluent containing radionuclides (Table E-XIV). Water in these canyons contain radionuclides as the result of effluent from the treatment plants.
The three areas, Acid-Pueblo, DP-Los Alamos, and Mortandad Canyons, contain surface and ground water with measurable amounts of radioactivity that are well below CGs for controlled areas. Surface and ground waters of these canyons are not a source of municipal, industrial, or agricultural supply. Surface waters in these canyons normally infiltrate into the alluvium of the stream channel within LASL boundaries. Only during periods of heavy precipitation or snowmelt does water from Acid-Pueblo and DP-Los Alamos Canyons reach the Rio Grande. In Mortandad Canyon, there has been no surface water runoff past the LASL boundary since hydrologic studies in the canyon began in $1960,3 \mathrm{yr}$ before release of any industrial effluents. 


\section{Radioactivity in Soil and Sediment}

Soil samples were collected from 37 stations and sediment samples from 59 stations in and adjacent to the Los Alamos area. Concentrations of ${ }^{239} \mathrm{Pu}$ from one regional soil station and ${ }^{\circ} \mathrm{Sr}$ from one regional sediment station were about three times worldwide fallout levels. Seven soil and nine sediment perimeter stations, and twelve soil and twenty seçiment onsite stations contained concentrations of radioactivity in excess of normal or fallout levels. The concentrations of radioactivity from these stations are less than three times the normal or fallout levels except in areas where treated radioactive effluents are released.

a. Regional Soil and Sediments. Regional soils are collected in the same general locations as regional waters (Fig. 7). Regional sediments are also collected at the same general locations with ad. ditional samples collected from Otowi to Cochiti from the Rio Grande. The exact locations are presented in Table E.XV (see Appendix B.3 for methods of collection, analysis, and reporting of soil and sediment data) and detailed results are in Table E.XVI.

Regional and perimeter soil and sediment radiochemical data collected from 1974 through 1978 are used to distinguish background radioactivity (from natural and worldwide fallout) from atmospheric nuclear weapons tests. ${ }^{7}$ This criteria is used for comparison using the mean plus twice the standard deviation for a number of analyses for a certain radionuclide from 1974 through 1977 (Table $\mathrm{XI})$. The mean plus twice the standard deviation includes approximately $95 \%$ of the population of the samples.

Maximum concentrations of radionuclides in the regional samples were near or below maximum concentration for natural and worldwide fallout except for samples from Chamita and from the Rio Grande at Ancho. The soil sample from Chamita contained about $0.14 \mathrm{pCi} / \mathrm{g}$ of ${ }^{239} \mathrm{Pu}$ or three times the criteria. Chamita is about $30 \mathrm{~km} \mathrm{NE}$ of Los Alamos up hydrologic gradient and beyond the influence of airborne emissions. The sediment sample from the Rio Grande at Ancho contained about $2.5 \mathrm{pCi} / \mathrm{g}$ of ${ }^{\circ} \mathrm{Sr}$ or about three times the criteria. The station is located in the drainage from Los Alamos, so may represent transport by storm runoff into the river. Both the ${ }^{230} \mathrm{Pu}$ and ${ }^{\circ} \mathrm{Sr}$ concentrations are apparently due to variability in fallout, since none of the other regional stations showed anomalous results. b. Perimeter Soils and Sediments. Eight perimeter soil stations were sampled in areas within $4 \mathrm{~km}$ of the Laboratory. Nineteen sediment samples were collected from major intermittent streams that cross Pajarito Plateau. Locations of the stations are described in Table E-XV and are shown on Fig. 13. Detailed analyses are shown on Table E-XVII.

Soil analyses indicate that ${ }^{3} \mathrm{H}$ from one station, ${ }^{197} \mathrm{Cs}$ from five stations, ${ }^{00} \mathrm{Sr}$ from one station, ${ }^{250} \mathrm{Pu}$ and gross beta from two stations, and total $U$ from three stations were slightly above maximum background $(x+2 s)$ criteria (Table XII) based on 1974-1977 data. The ${ }^{\text {on}} \mathrm{Sr}$ and ${ }^{239} \mathrm{Pu}$ concentrations are at locations adjacent to TA-21 and are due to deposition from stack emission at the site. Similar concentrations were reported during a study in $19700^{\circ}$

Sediment analyses indicated that ${ }^{137} \mathrm{Cs}$ and ${ }^{288} \mathrm{Pu}$ from two stations, ${ }^{80} \mathrm{Sr}$ from three stations, and ${ }^{230} \mathrm{Pu}$ from six stations were above background in AcidPueb!s and lower Los Alamos Canyons. Industrial effluents were released into Acid-Pueblo Canyon before 1964 and residual radionuclides remain there. Concentrations in lower Los Alamos Canyon (Totavi to the Rio Grande) reflect transport by intermittent storm runoff from Acid-Pueblo Canyon and from onsite release of industrial effluents into DP-Los Alamos Canyon. The concentrations decrease downgradient in the canyons (Table E-XVII).

c. Onsite Soil and Sediments. Onsite soil samples were collected from 19 stations within Laboratory boundaries. Sediment samples were collected from 31 stations within the boundaries (Fig. 13, Table E-XV). Analytical results are shown on Table E-XVIII and maximum concentrations in Table XIII. 


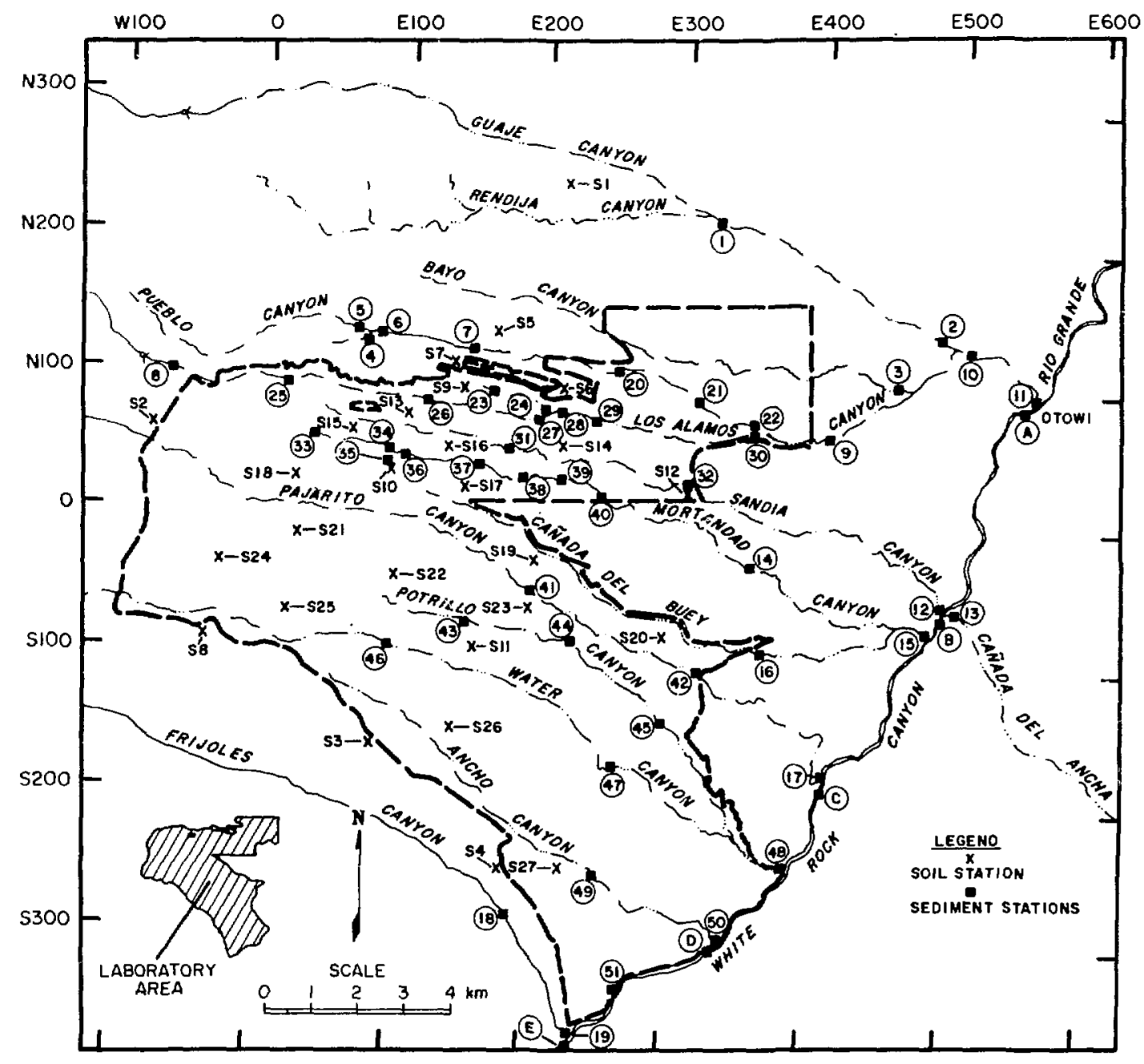

Fig. 13.

Soil and sediment sampling locations on or near the LASL site. 
TABLE XI

\section{MAXIMUM RADIOACTIVITY IN REGIONAL SOILS AND SEDIMENTS \\ (Concentrations in $\mathbf{p C i} / \mathrm{g}$, except as noted)}

\begin{tabular}{|c|c|c|c|}
\hline Analysis & Soil & Sediments & $\begin{array}{l}\text { Maximum Natural and } \\
\text { Worldwide Fallout for } \\
\text { Northern New Mexico }\end{array}$ \\
\hline${ }^{3} \mathrm{H}^{\mathrm{b}}$ & 1.9 & ... & $27^{c}$ \\
\hline${ }^{187} \mathrm{Cs}$ & 0.96 & 0.32 & 0.92 \\
\hline${ }^{\circ} \mathrm{Sr}$ & 0.44 & $0.12^{\mathrm{d}}$ & 0.79 \\
\hline${ }^{261} \mathrm{Am}$ & 0.011 & -.- & $\ldots$ \\
\hline${ }^{238} \mathrm{Pu}$ & $<0.004$ & $<0.005$ & 0.008 \\
\hline${ }^{230} \mathrm{Pu}$ & $0.023^{e}$ & 0.039 & 0.028 \\
\hline Gross alpha & 11 & 13 & 10.4 \\
\hline Gross beta & 13 & 15 & 11.2 \\
\hline Total Ur & 4.1 & 3.2 & 4.4 \\
\hline
\end{tabular}

\footnotetext{
Maximum value $(\bar{x}+2 \mathrm{~s})$ for soil and sediments 1974-77 (Ref. 7).

${ }^{b} 10^{-6} \mu \mathrm{Ci} / \mathrm{m} \ell$.

${ }^{c}(\bar{x}+2$ s) for regional soils 1978 .

${ }^{d}$ Maximum value except for sample Rio Grande at Ancho of $2.5 \mathrm{pCi} / \mathrm{g}{ }^{\circ} \mathrm{Sr}$.

'Maximum value except for sample from Chamita of $0.14 \mathrm{pCi} / \mathrm{g}{ }^{219} \mathrm{Pu}$.

' $\mu \mathrm{g} / \mathrm{g}$.
}

Note: < value represents analytical value plus twice the uncertainty term for that analysis.

In areas that have not received industrial effluents, concentrations of ${ }^{137} \mathrm{Cs}$ from seven stations, ${ }^{80} \mathrm{Sr}$ from one station, ${ }^{298} \mathrm{Pu}$ from two stations, ${ }^{230} \mathrm{Pu}$ and gross alpha from seven stations, gross beta from eight stations, and total $U$ from five stations in onsite soils were above background levels (Table XIII). These levels may be due to deposition of airborne effluents from Laboratory operations either from TA21 or TA-50. . $^{\mathrm{B}, \mathrm{s}}$

Sediment stations in Acid-Pueblo, DP-Los Alamos, and Mortandad Canyons contained radionuclides above background levels. These canyons have or are now receiving treated industrial liquid effluents (Table E.XVIII). Radionuclides in effluents are adsorbed or attached to sediment particles in the alluvium and their concentrations are highest near effluent outfalls. They decrease in concentration downgradient in the canyon as sediments and radionuclides are transported and dispersed by other industrial effluents, sanitary effluents, and periodic storm runoff.

Other samples containing above background levels of radionuclides were in Mortandad Canyon near the CMR Facility (station 33, Fig. 12), ${ }^{238} \mathrm{Pu}$, and ${ }^{230} \mathrm{Pu}$; Pajarito Canyon at TA-18 (station 41), total U; Potrillo Canyon at TA-36 (station 43), total $\mathrm{U}$; and Potrillo Canyon east of TA-36 (station 44) ${ }^{90} \mathrm{Sr}$. The concentrations range from slightly above background levels to a factor of three above background levels (Table E-XVIII).

\section{d. Radionuclide Transport in Snowmelt} Runoff, Spring 1979. The major transport of radionuclides from canyons receiving treated liquid radioactive effluents is in storm runoff (solution and suspended sediments). During the spring of 1979 , snowmelt runoff samples were collected in Guaje, 
TABLE XII

MAXIMUM RAD'OACTIVITY IN PERIMETER SOILS AND SEDIMENTS-
(Concentrations in pCi/g, except as noted)

\begin{tabular}{|c|c|c|c|c|}
\hline \multirow[b]{2}{*}{ Analysis } & \multicolumn{2}{|c|}{ Soil } & \multicolumn{2}{|c|}{ Sediments } \\
\hline & $\begin{array}{c}\text { Above } \\
\text { Background }\end{array}$ & Background & $\begin{array}{c}\text { Above } \\
\text { Background }\end{array}$ & Background \\
\hline${ }^{3} \mathrm{H}^{\mathrm{b}}$ & 96. (1) & 3. (7) & $\cdots$ & -.- \\
\hline${ }^{197} \mathrm{Cs}$ & $1.29(5)$ & $0.90(3)$ & $1.39(2)$ & $0.52(17)$ \\
\hline${ }^{80} \mathrm{Sr}$ & $1.1(1)$ & $0.79(7)$ & $2.25(3)$ & $0.68(12)$ \\
\hline${ }^{209} \mathrm{Pu}$ & $\ldots$ & $<0.004(8)$ & $0.68(2)$ & $0.006(17)$ \\
\hline${ }^{23} \mathrm{Pu}$ & $0.066(2)$ & $0.026(6)$ & $10.6(6)$ & $0.004(13)$ \\
\hline Gross alpha & ..- & 10. (8) & 12. (1) & $6.8(18)$ \\
\hline Gross beta & 14. (2) & $9.5(6)$ & 12. (1) & $5.6(18)$ \\
\hline Total Uc & $5.3(3)$ & $4.7(5)$ & $4.8(2)$ & $3.9(17)$ \\
\hline
\end{tabular}

"Parentheses indicate number of stations in group with maximum value noted. Background criteria is that given for natural and worldwide fallout as shown in Table XI.

${ }^{b} 10^{-6} \mu \mathrm{Ci} / \mathrm{m} \ell$ of moisture distilled from soil sample.

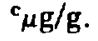

TABLE XIII

MAXIMUM RADIOACTIVITY IN ONSITE

SOILS AND SEDIMENTS*

(Concentrations in $\mathrm{pCi} / \mathrm{g}$, except as noted)

\begin{tabular}{|c|c|c|c|c|}
\hline \multirow[b]{2}{*}{ Analysis } & \multicolumn{2}{|c|}{ Soils } & \multicolumn{2}{|c|}{ Sediments } \\
\hline & $\begin{array}{c}\text { Above } \\
\text { Background }\end{array}$ & Background & $\begin{array}{c}\text { Above } \\
\text { Background }\end{array}$ & Background \\
\hline${ }^{5} \mathrm{H}^{\mathrm{b}}$ & -.. & $26 \quad(19)$ & $\ldots$ & --- \\
\hline${ }^{197} \mathrm{Cs}$ & $3.1(7)$ & $0.77(12)$ & $360 \quad(8)$ & $0.89(23)$ \\
\hline${ }^{\infty} \mathrm{Sr}$ & $0.90(1)$ & $0.56(6)$ & $3.47(7)$ & $0.52(9)$ \\
\hline${ }^{250} \mathrm{Pu}$ & $0.234(2)$ & $0.003(17)$ & $5.75(9)$ & $0.004(22)$ \\
\hline${ }^{350} \mathrm{Pu}$ & 0.127 (7) & $0.023(12)$ & $2.38(15)$ & $0.035(16)$ \\
\hline Gross alpha & $18(7)$ & $10(12)$ & $14,1)$ & $8.3(24)$ \\
\hline Gross beta & $19(8)$ & 11 (11) & $32(4)$ & $11(21)$ \\
\hline Total U' & $7.1(5)$ & $4.4(14)$ & $15(3)$ & $4.3(22)$ \\
\hline
\end{tabular}

- Parentheses indicate number of stations in group with maximum value noted. Background criteria is that given for natural and worldwide fallout as shown in Table XI.

${ }^{\circ} 10^{-}{ }_{\mu} \mathrm{Ci} / \mathrm{m} \ell$ of moisture distilled from soil sample.

${ }^{{ } \mu \mathrm{g} / \mathrm{g} \text {. }}$ 
Rendija, Pueblo, Los Alamos (3 stations), Mortandad, Pajarito, Water, and Ancho Canyons (Table E$\mathrm{XIX)}$. Analyses of dissolved commitments were performe $\mathrm{d}$ for ${ }^{3} \mathrm{H},{ }^{137} \mathrm{Cs},{ }^{258} \mathrm{Pu},{ }^{230} \mathrm{Pu},{ }^{20} \mathrm{Sr}$, and total $\mathrm{U}$. Also chemical analyses were made for $\mathrm{SO}_{4}, \mathrm{Cl}, \mathrm{F}$, $\mathrm{NO}_{\text {, }}$ and TDS. Suspended sedimerts were analyzed for ${ }^{230} \mathrm{Pu}$ and ${ }^{230} \mathrm{Pu}$. Analyses from Guaje anı Rendija Canyons were used for controls (background) as these stations are about $6 \mathrm{~km}$ north of the Laboratory.

A number of samples were collected during spring runoff. Analyses of individual samples varied considerably as shown by the standard deviation of the distribution of the observed values. Tritium in solution was above normal levels and occurred at times in Los Alamos Canyon at SR-4, Totavi, and Otowi, as well as in Pajarito, Mortandad, and Ancho Canyons.

Cesium-137 in solution was near or below normal levels at all stations. The ${ }^{258} \mathrm{Pu}$ concentrations were above normal concentrations in Mortandad Canyon, whereas ${ }^{236} \mathrm{Pu}$ exceeded normal levels in one out of five analyses in Pueblo Canyon and in the five analyses in Mortandad Canyon. The ${ }^{\circ} \mathrm{Sr}$ in solution occurred in Los Alamos Canyon at SR-4, Totavi, and Otowi and in Mortandad Canyon. Total $U$ in solution was high in Mortandad Canyon.

Concentrations of radioactivity in suspended sediments cannot be compared directly to concentrations found in the bed sediments discussed in Sections III.A.4.b and III.A.4.c. The silt and clay fraction makes up almos, all of suspended sediment while the silt and clay fraction comprises only about $5 \%$ (by iveight) of the bed sediments. As expected, the concentrations of ${ }^{230} \mathrm{Pu}$ in suspended sediments were elevated in Mortandad Canyon, while the concentrations of ${ }^{239} \mathrm{Pu}$ were elevated in Mortandad Canyon, Pueblo Canyon, and Los Alamos Canyon at SR-4, Totavi, and Otowi (Table E-XIX).

In summary, most of the concentrations of radioactivity above background found in solution and suspended sediments occurred in Pueblo, Los Alamos, and Mortandad Canyons. These three can- yons have or are now receiving treated radioactive effluents. Some snowmelt and thunderstorm runoff from Pueblo and Los Alamos Canyons reaches the Rio Grande. Runoff in Mortandad Canyon infiltrates alluvium within Laboratory boundaries. Li-

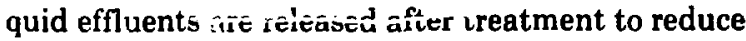
radioactivity ievels well below CGs for controlled areas. Transport of radionuclides occurs from ad. sorption or retention of radionuclides in effluents on bed sediments in effluent release areas.

The chemical quality of selected constituents in snowmelt runoff follows the same general pattern as radionuclides (Table E-XIX). Sulfates show no particular trends. Chlorides were high in runoff from Pueblo, Los Alamos, Mortandad, and Pajarito Canyons from perturbances of man, industrial effluent, sanitary effluent or possible from salt-sand mixture used for snow removal. Fluoride and nitrates in Mortandad Canyon are from release of industrial effluents, whereas nitrates in Pueblo Canyon reflect release of sanitary effluents.

e. Plutonium in Bed Sediments from the Rio Chama and Rio Grande. Seven samples of bed sediments from the Rio Chama and Rio Grande were collected in August. Special analyses were performed using $1 \mathrm{~kg}$ ( 100 times the mass normally used for analysis) of sediment to increase sensitivity of the analyses (Table XIV). The concentrations fall within the range observed for worldwide fallout on sediments in Northern New Mexico of $<0.008 \mathrm{pCi} / \mathrm{g}$ for ${ }^{230} \mathrm{Pu}$ and $<0.028 \mathrm{pCi} / \mathrm{g}$ for ${ }^{230} \mathrm{Pu} .{ }^{7}$ The average for the five stations in White Rock Canyon (below drainage from LASL) is identical with that obtained from the four years of analyses in northern New Mexico. The slight variability in concentrations of plutonium between individual stations is attributable to the fact that the samples were not separated by particle size and to different degrees of mixing between freshly eroded sediments and older sediments which had been exposed to worldwide fallout. 
TABLE XIV

\section{PLUTONIUM IN BED SEDIMENTS FROM \\ THE RIO CHAMA AND RIO GRANDE \\ (Concentrations in $\mathrm{pCi} / \mathrm{g}$ )}

\begin{tabular}{lll}
\multicolumn{1}{c}{ Location } & ${ }^{230} \mathbf{P u}$ & ${ }^{23} \mathbf{P u}$ \\
$\begin{array}{l}\text { Rio Chama } \\
\text { At Chamita }\end{array}$ & $0.0000 \pm 0.0000$ & $0.0003 \pm 0.0000$ \\
$\begin{array}{l}\text { Rio Grande } \\
\text { At Embudo }\end{array}$ & $0.0001 \pm 0.0000$ & $0.0017 \pm 0.0002$ \\
Relow Otowi & $0.0002 \pm 0.0000$ & $0.0073 \pm 0.0004$ \\
At Sandia Canyon & $0.0001 \pm 0.0000$ & $0.0043 \pm 0.0004$ \\
At Pajarito Canyon & $0.0001 \pm 0.0002$ & $0.0010 \pm 0.0004$ \\
At Ancho Canyon & $0.0005 \pm 0.0000$ & $0.0088 \pm 0.0004$ \\
At Frijoles Canyon & $0.0000 \pm 0.0000$ & $0.0023 \pm 0.0004$ \\
Note: \pm value represents twice the analytical uncertainty \\
associated with that analysis.
\end{tabular}

\section{Radioactivity in Foodstuffs}

Fruit, vegetable, fish, and honey samples collected in the vicinity of LASL showed no apparent influence from Laboratory operations, except for apricots and peaches collected onsite and honey collected near facilities that emit tritium.

Fruit, vegetable, fish, and honey samples were collected during the fall to monitor foodstuffs for possible radioactive contamination from Laboratory operations. Fruits and vegetables were collected in the Los Alamos area and in the Rio Grande valley above and below confluences of the intermittent streams which cross the Laboratory and flow into the Rio Grande (see Fig. 7). Fish were collected from locations above (Abiquiu, El Vado, and Heron reservoirs which are on the Rio Chama, a tributary of the Rio Grande) and below (Cochiti) confluences of these streams. Fish samples were taken from bottom feeders, such as carp and suckers, which have a greater probability than higher trophic orders of ingesting any activity that might be associated with sediments. Honey was collected from hives established in 1978 at several locations within the LASL boundary near waste stream outfalls and a tritium facility. Background samples came from other LASL locations, Barranca Mesa (in Los
Alamos), Pajarito Acres (in White Rock), and Chimayo, New Mexico.

Fruit and vegetable samples were analyzed for tritiated water (HTO), ${ }^{2 s a} \mathrm{Pu}$, and ${ }^{2 s} \mathrm{Pu}$. Fish sample analyses included gross gamma, ${ }^{23} \mathrm{Pu},{ }^{20} \mathrm{Pu},{ }^{\circ} \mathrm{Sr}$, and total uranium. Honey samples were analyzed for HTO and ${ }^{197} \mathrm{Cs}$.

Data presented in Tables XV and XVI summarize fruit and vegetable sample results for tritium and plutonium according to different water supplies. Sample moisture ranged from $47 \%$ to $96 \%$ of total sample weight. With the exception of onsite samples (TA-35 and TA-21) there is no significant difference in HTO content between any batches of samples analyzed. Observed concentrations are within the range of values measured in local surface water and atmospheric water vapor. Thus, there is no indication of any measurable offsite contribution from Laboratory operations. The tritium content of 


\section{TRITIATED WATER CONTENT OF FRUITS AND VEGETABLES}

\begin{tabular}{|c|c|c|c|c|}
\hline \multirow[b]{2}{*}{ Location } & \multirow[b]{2}{*}{ Water Source } & \multirow[b]{2}{*}{$\begin{array}{c}\text { No. of } \\
\text { Samples }\end{array}$} & \multicolumn{2}{|c|}{$\begin{array}{c}\text { Tritiated Water } \\
\text { Concentration }(\mathrm{pCi} / \mathrm{m} \ell)\end{array}$} \\
\hline & & & $\begin{array}{c}\text { Average } \\
( \pm 1 \text { s })\end{array}$ & Range \\
\hline Espanola & Rio Grande & 5 & $0.90 \pm 0.45$ & 0.40 to 1.5 \\
\hline Espanola & Rio Chama & 5 & $0.96 \pm 0.18$ & 0.80 to 1.2 \\
\hline Cochiti & Rio Grande & 5 & $0.86 \pm 0.21$ & 0.60 to 1.1 \\
\hline Los Alamos & Community System & 4 & $1.13 \pm 0.61$ & 0.40 to 1.8 \\
\hline Pajarito Acres & Community System & 5 & $1.00 \pm 0.29$ & 0.80 to 1.5 \\
\hline White Rock & Community System & 3 & $1.03 \pm 0.23$ & 0.90 to 1.3 \\
\hline TA-35 & Community System & 1 & 15.7 & \\
\hline TA-21 & Precipitation & 2 & $9.7 \pm 11.8$ & 1.4 to 18 \\
\hline
\end{tabular}

-Upstream from Laboratory stream confluence.

'Downstream from Laboratory stream confluence.

TABLE XVI

PLUTONIUM CONTENT OF FRUITS AND VEGETABLES

\begin{tabular}{|c|c|c|c|c|c|c|}
\hline \multirow[b]{2}{*}{ Location } & \multirow[b]{2}{*}{ Water Source } & \multirow[b]{2}{*}{$\begin{array}{l}\text { No. of } \\
\text { Samples }\end{array}$} & \multicolumn{2}{|c|}{${ }^{2 a P u}(\mathrm{fCj} / \mathrm{g})^{\mathrm{c}}$} & \multicolumn{2}{|c|}{${ }^{200} \mathrm{Pu}(\mathrm{fCi} / \mathrm{g})^{\mathrm{c}}$} \\
\hline & & & $\begin{array}{c}\text { Average } \\
( \pm 1 \mathrm{~s}) \\
\end{array}$ & Range & $\begin{array}{c}\text { Average } \\
( \pm 1 \text { s) }\end{array}$ & Range \\
\hline Espanola & Rio Grande & 5 & $-0.4 \pm 0.3$ & -0.7 to -0.07 & $0.08 \pm 0.3$ & -0.3 to 0.5 \\
\hline Espanola & Rio Chama & 5 & $-0.07 \pm 0.2$ & -0.3 to 0.2 & $-0.2 \pm 0.1$ & -0.4 to -0.09 \\
\hline Cochiti & Rio Grande ${ }^{b}$ & 5 & $-0.2 \pm 0.4$ & -0.6 to 0.3 & $-0.1 \pm 1.0$ & -0.8 to 1.6 \\
\hline Los Alamos & Community System & 4 & $-0.6 \pm 0.3$ & -1. to 0.4 & $-0.5 \pm 0.2$ & -0.7 to -0.3 \\
\hline Pajarito Acres & Community System & 5 & $0.02 \pm 0.3$ & -0.7 to 0.1 & $0.06 \pm 0.2$ & -0.3 to 0.08 \\
\hline White Rock & Community System & 3 & $-0.07 \pm 0.2$ & -0.1 to 0.3 & $0.07 \pm 0.2$ & -0.1 to 0.2 \\
\hline TA-35 & Community System & 1 & -0.1 & & 1.6 & \\
\hline TA-21 & Precipitation & 2 & $0.04 \pm 0.05$ & 0. t 0.07 & $0.8 \pm 0.1$ & 0.7 to 0.9 \\
\hline
\end{tabular}

-Upstream from Laboratory stream confluence.

'Downstream from Laboratory stream confluence.

'Dry weight. 
peaches at TA-35 was similar to previously reported relatively higher values at that location..$^{\circ} \mathrm{A}$ major source of tritium at TA-35 (tritium-contaminated gloveboxes which off-gassed through a $23 \mathrm{~m}$ stack) was removed and disposed during 1979. The elevated HTO concentrations in apricots were from a tree located near a facility in TA-21 where tritium operations are conducted and where some tritium is released. The few peaches and apricots do not represent a significant pathway to man because they are within a Laboratory fence, represent a very small volume of ingestible water, and have considerably less tritium than the uncontrolled area $C G$ for water $(3000 \mathrm{pCi} / \mathrm{m} \ell)$ and less than the EPA's drinking water standard $(20 \mathrm{pCi} / \mathrm{m} \ell)$.

None of the samples collected had measurable ${ }^{239} \mathrm{Pu}$ (i.e., where the $2 \mathrm{~s}$ measurement error was less than the measured value). Only five samples had detectable ${ }^{239} \mathrm{Pu}$ activity. Results are summarized in Table XVI. Ingestion of $3.0 \mathrm{~kg}$ of fresh carrots (annual per capita consumption of carrots) ${ }^{10}$ contaminated to $1.6 \times 10^{-3} \mathrm{pCi} / \mathrm{g}$ (dry weight) of ${ }^{230} \mathrm{Pu}$ (the maximum value which was in a sample of carrots) would result in a $50 \mathrm{yr}$ dose commitment of 2.1 $\times 10^{-4}$ mrem to the critical oryan (bone). The magnitude of the contamination $a$ id doses indicate they are due to fallout or soil contarination on plant surfaces and not to Laboratory related effluents.

Data on radioactivity in fish are presented in Table XVII. For all determinations, the fish flesh was analyzed so some bone was included in the samples. Uranium content is elevated in the gut indicating sediment ingestion. Uranium in fish samples from Cochiti is statistically higher than in the background samples. Rio Grande sediment samples (above and below the Laboratory) have statistically higher uranium concentrations (see Table E-XVI) than the Rio Chama station at Chamita, but the uranium in water is higher at Chamita than along the Rio Grande (see Table E-XI). More significantly, sediment from Los Alamos Canyon has uranium concentrations (Table E-XVI) virtually the same as sediments from the Rio Grande (Table E-XVII) above and below their confluence. Thus, there is no basis for attributing the difference in fish to transport of sediments from Los Alamos Canyon. Whatever the cause, a person eating $18 \mathrm{~kg}$ of fish from Cochiti would get a $50 \mathrm{yr}$ dose commitment of $0.03 \mathrm{mrem}$ to the bone and 0.007 mrem to the kidney over what he would get if the fish came from the Rio Chama. All ${ }^{238} \mathrm{Pu}$ data are less than detection limits. The two positive ${ }^{239} \mathrm{Pu}$ samples are in the gut which indicates the material was ingested. The largest of these two positive values is from Abiquiu which is not influenced by Laboratory operations. Strontium -90 values are low and vary widely, with values from Cochiti not statistically different from levels at background locations.

The 1979 honey samples and library of honey samples collected in 1977 by LASL's Environmental Studies Group were analyzed for ${ }^{137} \mathrm{Cs}$ and HTO. In all cases ${ }^{137} \mathrm{Cs}$ results were less than detection limits (the measured value was $\leq$ the $2 \mathrm{~s}$ of the measurement). Results of the HTO measurements are given in Table XVIII and are consistent with previously measured values. "If a person ate $5 \mathrm{~kg}$ of honey from the hive with the maximum HTO concentration (579 $\mathrm{pCi} / \mathrm{m} \boldsymbol{l}$ at $\mathrm{TA}-33$ ), the whole body dose would be 0.024 mrem which is $0.005 \%$ of the Radiation Protection Standard for members of the public.

\section{Radioactive Effluents}

Airborne radioactive effluents released from LASL operations in 1979 were typical of releases during the past several years. The greatest change was about a tenfold increase in plutonium effluents due to problems caused by aging equipment in one facility. Liquid effluents from three waste treatment plants contained radioactivity at levels well below controlled area Concentration Guides. 
TABLE XVII

\section{RADIOACTIVITY IN FISH}

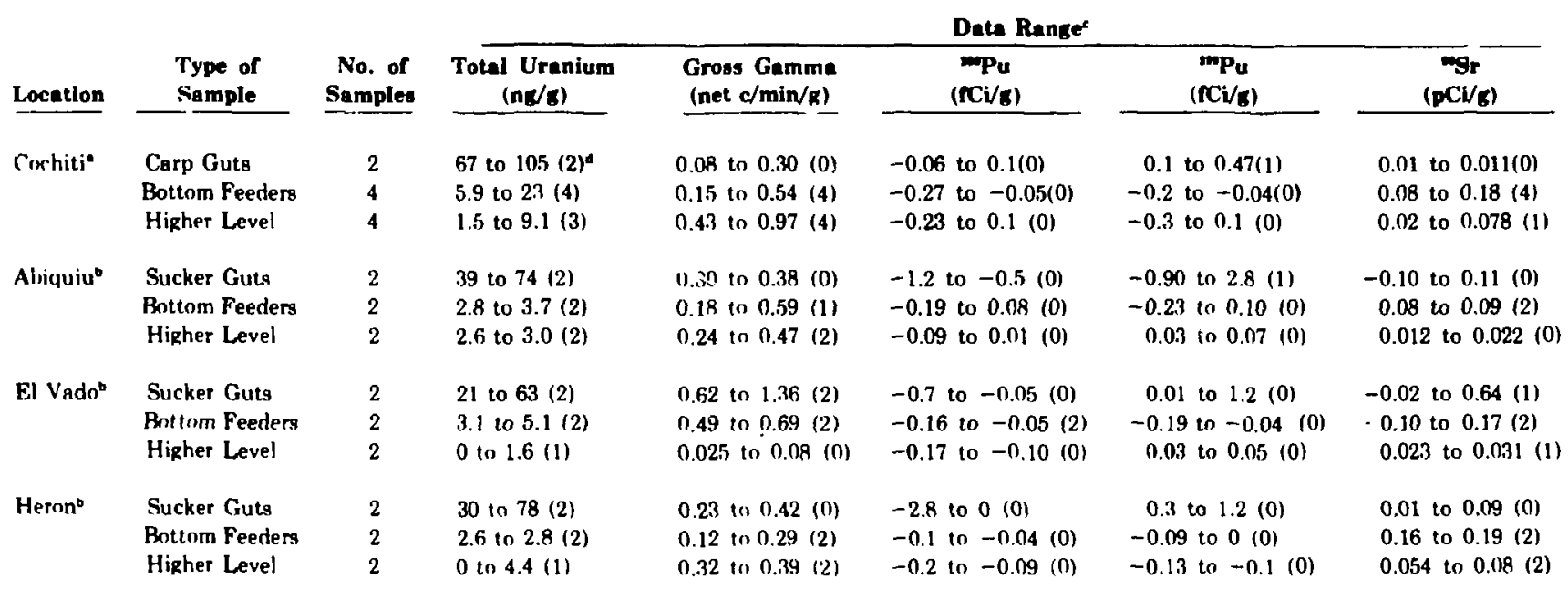

- Helow contluence of the Rio Grande with intermittent Laboratury streims.

a Above confluence of Rin (irande with intermittent Labnratory wireams.

c'oncentrations are hased on tiswue weight after aven drying.

- Number in parent heses indicale $\times$ number of samples $>$ MI)l. 
TABLE XVIII

\section{HTO CONCENTRATION IN HONEY SAMPLES}

\begin{tabular}{l} 
Location \\
\hline Mortandad \\
Effluent \\
DP \\
TA-33 \\
Area G \\
S-Site \\
Pajarito Acres \\
Barranca Mesa \\
Chimayo
\end{tabular}

\begin{tabular}{|c|c|}
\hline 1977 & 1979 \\
\hline $55.7 \pm 1.1$ & $11.8 \pm 0.5$ \\
\hline $115 \pm 1.9$ & $26.7 \pm 0.7$ \\
\hline $39.5 \pm 0.8$ & $5.8 \pm 0.4$ \\
\hline $85.2 \pm 1.5$ & $579 \pm 9$ \\
\hline ... & $9: 6 \pm 0.4$ \\
\hline $8.4 \pm 0.4$ & $2.8 \pm 0.4$ \\
\hline $7.3 \pm 0.4$ & $10.5 \pm 0.4$ \\
\hline -.. & $3.6 \pm 0.4$ \\
\hline$\ldots$ & $0.6 \pm 0.3$ \\
\hline
\end{tabular}

${ }^{\mathrm{a}} \mathrm{pCi} / \mathrm{m} \ell$ of water in the honey. Honey is $\sim 17.2 \%$ water. ${ }^{12}$

Data is formatted $\bar{x} \pm 1 \mathrm{~s}$.
Effluents containing radioactivity are discharged at LASL as airborne materials in stack exhausts at 12 of the technical areas and as liquid discharges from 2 industrial waste treatment plants and 1 sanitary sewage lagoon system. The airborne effluents consist principally of filtered ventilation exhausts from gloveboxes, other experimental facilities, some process facilities such as the liquid waste treatment plants, exhausts from the research reactor, and exhausts from the linear accelerator at LAMPF. Releases of various isotopes from the technical areas are detailed in Table E-XX. Quantities of radioactivity released depend on research programs conducted, so vary significantly from yearto-year (see Figs. 14-16).

Routine airborne tritium effluents were down by about $35 \%$ this year compared with 1978 (see Fig. 14). However, there was an accidental release of 3000 $\mathrm{Ci}$ on May 4 (see Section III.A.7). This $3000 \mathrm{Ci}$ is about $25 \%$ of the $12026 \mathrm{Ci}$ routinely released during 1979.

Airborne plutonium effluents were higher by a factor of about 10 in 1979 compared to 1978 (see Fig. 16). Almost all of the increase was due to problems caused by aging equipment in one wing of an experimental building in the main technical area (TA-
$3)$. The majority ( $90 \%$ ) of releases from this source occurred during the first and fourth quarters. This source contributed $1060 \mu \mathrm{Ci}$ (about $98 \%$ ) out of the annual total plutonium emissions of $1086 \mu \mathrm{Ci}$ for the entire LASL site, indicating all other facilities have achieved better control than in the past. Large filters were replaced in March and engineering studies were initiated for refurbishing and installation of new High Efficiency Particulate Air filters. During the fourth quarter, emissions again increased because of further equipment detericration. Corrective measures have been implemented to control a major source of the release. Total correction of the problem will involve major capital expenc .cures.

In addition to airborne releases from stacks, some depleted uranium (uranium consisting almost entirely of ${ }^{238} \mathrm{U}$ ) is dispersed by experiments employing conventional high explosives. In 1979 about $568 \mathrm{~kg}$ of depleted uranium were used in such experiments. Based on known isotopic composition, this mass is estimated to contain approximately $0.20 \mathrm{Ci}$ of activity. Most debris from these experiments is deposited on the ground in the vicinity of the firing point. Limited experimental information indicates that no more than about $10 \%$ of the depleted uranium becomes airborne. Approximate dispersion 


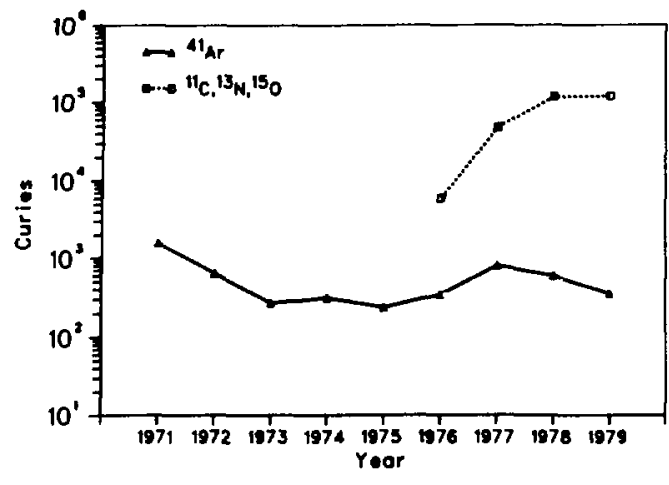

Fig. 14.

Summary of atmospheric releases of " $\mathrm{Ar},{ }^{\mathrm{N}} \mathrm{C}$, ${ }^{19} \mathrm{~N}$ and ${ }^{16} \mathrm{O}$.

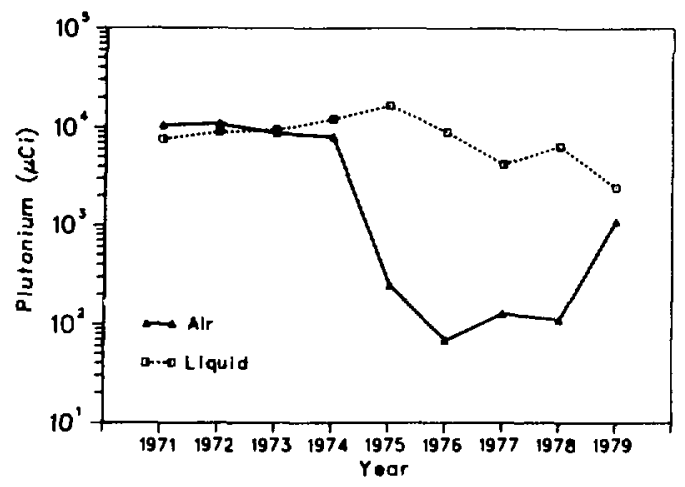

Fig. 16.

Summary of plutonium effiuents (air and liquid).

calculations indicate that resulting airborne concentrations would be in the same range as attributable to natural crustal-abundance uranium in resuspended dust. This theoretical evaluation is compatible with the concentrations of atmospheric uranium measured by the routine air sampling network (see Section III.A.2). Estimates of non$r$ adioactive releases from these experiments are discussed in Section III.B.3.

Treated liquid effluents containing low levels of radioactivity are released from the Central Liquid Waste Treatment Plant (TA-50), a smaller plant serving the old plutonium processing facility (TA21 , and two sanitary sewage lagoons serving

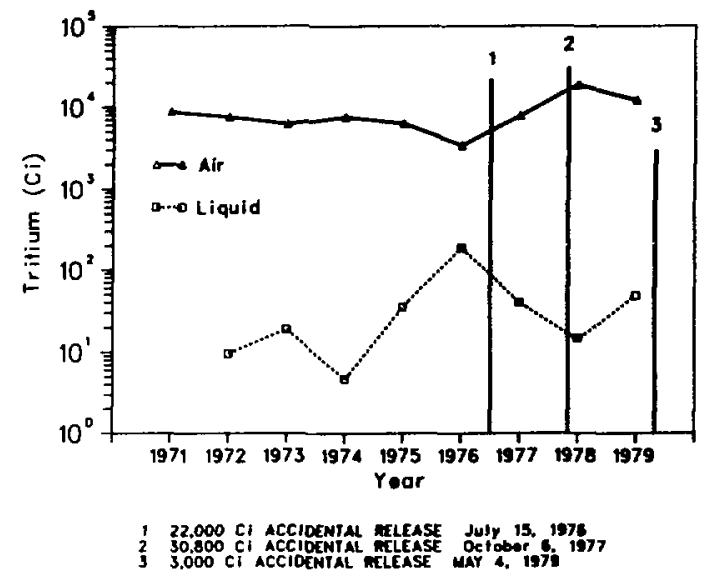

Fig. 15.

Summary of tritium effluents (air and liquid).

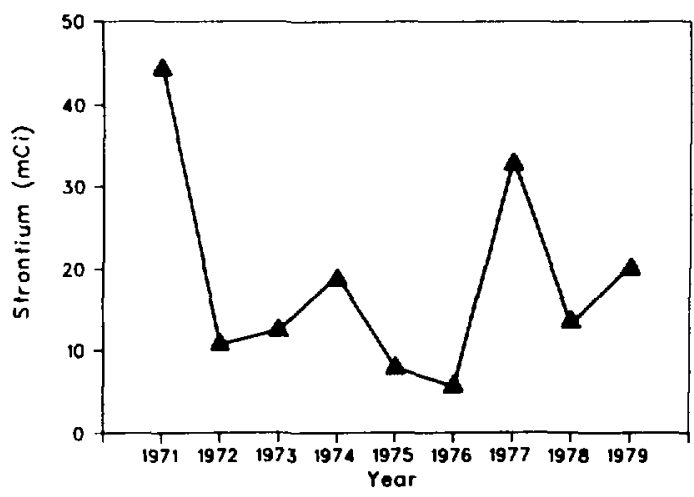

Fig. 17.

Summary of strontium liquid effluents.

LAMPF. Detailed results of the effluent radioactivity monitoring are in Table E-XX and Figs. 1517. Plutonium and cesium releases in 1979 were lower by factors of two to three, whereas americium, strontium, and tritium were higher by as much as 2.7 in comparison with 1978. Design vork is underway for upgrading TA-50, which will further reduce the amount of contrminants in the effluent. Activity released from $\mathrm{TA}-21$ is down by a factor of two for some isotopes and by a factor of four or more for the remainder of the radionuclides. Plutonium operations were moved from TA-21 in 1978 to TA-55. Remaining effluents at TA-21 are from decontamination operations. TA-55 liquid wastes are 
treated at TA-50. A total of $1.7 \times 10^{7} \ell$ of effluent was discharged from the TA -53 sanitary lagoons containing $0.021 \mathrm{Ci}$ of ${ }^{22} \mathrm{Na}, 0.86 \mathrm{Ci}$ of ${ }^{7} \mathrm{Be}$, and $15 \mathrm{Ci}$ of ${ }^{3} \mathrm{H}$. The source of the radioactivity was activated water from beam stop cooling systems. None of the cuncentrations were at concentrations higher than about $0.9 \%$ of CGs for water in controlled areas. Samples of water, sediments, and transpirate from trees adjacent to the discharge from the lagoons have been collected this year and the results of this sampling program are discussed in Section IV.C.9.

Releases from the larger plant (TA-50) are discharged into a normally dry stream channel (Mortandad Canyon) in which surface flow has not passed beyond the Laboratory boundary since before the plant began operation. Discharges from the smaller plant (TA-21) are into DP Canyon, a tribut ary of Los Alamos Canyon where runoff does at limes flow past the boundary and transports some residual activity adsorbed on sediments. Effluent from the LAMPF lagoons sinks into alluvium within the Iaboratory boundary.

\section{Unplanned Releases}

On May 4, 1979, up to $0.31 \mathrm{~g}(3000 \mathrm{Ci})$ of tritium (probably as tritium gas and oxide) were released to the environment from an accidental overheating of a stainless steel pot containing uranium tritide at the Cryogenics Building (SM-34). Had the release been all tritium oxide (HTO) it would have been measured by the air sampling network, however, it was not detected. To estimate upper bound doses from the release, standard diffusion models were used and the entire release was conservatively as- sumed to be HTO. This estimate gives a maximum boundary dose (near the Omega Bridge) of 0.27 mrem which is $0.05 \%$ of the annual dose limit to members of the public. Since we were not able to measure in the atmosphere the release, it is likely that actual doses would probably be 10 to 100 times lower than those calculated. Aithough Royal Crest Mobile Home Park, the nearest offsite location, was not downwind from the release, the HTO concentration at the Park was somewhat higher $\left(16 \mathrm{pCi} / \mathrm{m}^{3}\right)$ than perimeter (average $2.9 \mathrm{pCi} / \mathrm{m}^{3}$, maximum 5.3 $\mathrm{pCi} / \mathrm{m}^{3}$ ) and regional (average $3.6 \mathrm{pCi} / \mathrm{m}^{2}$, maximum $8 \mathrm{pCi} / \mathrm{m}^{3}$ ) stations for this period, but was well within expected values for this station (1978 average $16 \mathrm{pCi} / \mathrm{m}^{3}$, maximum $\left.67 \mathrm{pCi} / \mathrm{m}^{3}\right)$.

On Oct. 31, 1979, a small amount of activated soil was released as airborne emissions from the Omega West Reactor Facility located in Los Alamos Canyon. A soil sample stuck in a sample irradiation port at the reactor. During attempts to remove the stuck sample, the sample container broke spreading activated soil throughout the sample handling room. Some of this activity (principally ${ }^{162 \mathrm{~m}} \mathrm{Eu}$, ${ }^{110 \mathrm{~m}} \mathrm{In}$, ${ }^{100} \mathrm{La}$, and ${ }^{24} \mathrm{Na}$ ) escaped to the environment through an unfiltered air exhaust in the room. Samples were collected from five routine air monitoring stations (TA-53, TA-21, Gulf Station, Royal Crest, and 48th Street) near Los Alamos Canyon and at two background locations (Well PM-1 and Espanola). None of the samples had detectable activity. Detection limits for these short-lived isotopes (maximum half life was $40 \mathrm{~h}$ ) were between 100 and 10000 times below the uncontrolled area CGs (which apply to continuous exposure) for those isotopes.

\section{B. Chemical Constituents}

\section{Chemical Quality of Surface and Ground Waters}

Chemical analyses of surface and ground waters from regional, perimeter, and onsite noneffluent release areas varied slightly from previous years; however, these variations in concentrations were within the normal range of seasonal fluctuations. The chemical quality of water from the municipal supply for the Laboratory and community meets the standards set by the EPA and New Mexico Environmental Improvement Division. Analyses from onsite effluent release areas indicated that some constituents were higher than in naturally-occurring waters; however, these waters are not a source of municipal, industrial, or agricultural supply. 
TABLE XIX

\section{MAXIMUM CHEMICAL CONCENTRATIONS IN REGIONAL AND PERIMETER WATERS \\ (concentrations in $\mathrm{mg} / \ell$ )}

\begin{tabular}{|c|c|c|c|c|}
\hline \multirow[b]{2}{*}{ Analysis } & \multirow[b]{2}{*}{ Regional } & \multicolumn{2}{|c|}{ Perimeter } & \multirow[b]{2}{*}{$\begin{array}{l}\text { Standard or } \\
\text { Criteria }\end{array}$} \\
\hline & & $\begin{array}{c}\text { Four } \\
\text { Stations }\end{array}$ & $\begin{array}{l}\text { White Rock } \\
\text { Canyon }\end{array}$ & \\
\hline $\mathrm{Ca}$ & 49 & 31 & 29 & $\ldots$ \\
\hline$M g$ & 12 & 8 & 9 & $\ldots$ \\
\hline $\mathrm{Na}$ & 45 & 32 & 116 & ... \\
\hline CI & 52 & 29 & 44 & 250 \\
\hline F & 0.8 & 0.6 & 1.0 & 2.0 \\
\hline $\mathrm{NO}_{3}$ & 1.4 & 16 & 32 & 45 \\
\hline TDS & 444 & 266 & 528 & 1000 \\
\hline
\end{tabular}

a. Regional and Perimeter. Regional and perimeter surface and ground waters were sampled at the same locations as were used for radioactivity monitoring (Table $\mathrm{E}-\mathrm{X}$ ). The regional surface waters were sampled at six stations, with perimeter waters sampled at four stations plus 23 stations in White Rock Canyon (Figs. 7 and 12). Detailed analyses from the regional and perimeter stations are presented in Tables E-XI and E-XII, respectively. (See Appendix B.3 for methods of collection, analyses, and reporting of water data.) The maximum concentrations for seven parameters are in Table XIX.

The chemical quality of surface water varies at given stations during a year because of dilution of base flow with runoff from precipitation. There has been no significant change in the quality of water from previous analyses.

b. Onsite Surface and Ground Waters. Water samples were collected from two surface water sta. tions and six wells completed in the main aquifer (Table E-XIII). They are located in onsite areas that do not receive industrial effluents (Fig. 12). Detailed results of analyses are given in Table E-XIV. The maximum concentrations for selected constituents are in Table XX. Water quality at the surface water stations varies slightly as base flow is diluted with varying amounts of storm runoff. The quality of sur- face and ground waters has not changed significantly from previous analyses.

Table E-XIV details the chemical quality analyses of surface and ground water from 26 stations located in canyons that receive sanitary and/or industrial effluent (Fig. 12, Table E-X). The maximum concentrations of selected constituents found in each canyon are summarized in Table XXI.

Acid-Pueblo Canyon received industrial effluents from 1943 to 1964 and currently is receiving treated sanitary effluents, which are now the major part of the flow. Sandia Canyon receives cooling tower blowdown and some treated sanitary effluents. DPLos Alamos and Mortandad Canyons receive treated industrial effluents that contain some radionuclides and residual chemicals used in the waste treatment process. The high TDS and chlorides reflect effluents released into the canyons. Fluorides and nitrates in DP-Los Alamos and Mortandad canyons were above drinking water standards; ${ }^{\circ}$ however, these onsite waters are not a source of municipal, industrial, or agricultural supply (Table XXI). The maximum concentrations occurred near the effluent outfalls. The chemical quality of the water improves downgradient from the outfall. There is no surface flow to the Rio Grande in these canyons except during periods of heavy precipitation. 


\section{TABLE XX}

\section{MAXIMUM CHEMICAL CONCENTRATIONS IN ONSITE NONEFFLUENT WATER}

(concentrations in $\mathrm{mg} / \ell$ )

\begin{tabular}{lcccc} 
Analysis & Surface Water & Ground Water & $\begin{array}{c}\text { Standard or } \\
\text { Criteria }\end{array}$ \\
\cline { 1 - 1 } $\mathrm{Ca}$ & & 7 & 32 & \\
$\mathrm{Mg}$ & 4 & 3 & $\cdots$ \\
$\mathrm{Na}$ & 15 & 21 & $\cdots$ \\
$\mathrm{Cl}$ & 17 & 13 & $\cdots$ \\
$\mathrm{F}$ & 0.7 & & 0.5 & 250 \\
$\mathrm{NO}$ & 3 & 3 & 2 \\
$\mathrm{TDS}$ & 192 & 186 & 45 \\
& & & & 1000
\end{tabular}

TABLE XXI

MAXIMUM CHEMICAL CONCENTRATIONS IN EFFLUENT AREA WATERS (concentrations in $\mathbf{m g} / \ell$ )

\begin{tabular}{|c|c|c|c|c|c|}
\hline Analysis & $\begin{array}{l}\text { Acid- } \\
\text { Pueblo }\end{array}$ & $\begin{array}{c}\text { DP- } \\
\text { Los Alamos }\end{array}$ & Sandía & Mortandad & $\begin{array}{c}\text { Standard or } \\
\text { Criteria }\end{array}$ \\
\hline $\mathrm{Ca}$ & 16 & 43 & 16 & 16 & $\cdots$ \\
\hline $\mathbf{M g}$ & 4 & 6 & 6 & 5 & --- \\
\hline $\mathrm{Na}$ & 69 & 130 & 128 & 146 & -- \\
\hline $\mathrm{Cl}$ & 61 & 127 & 93 & 22 & 250 \\
\hline $\mathbf{F}$ & 0.9 & 10 & 1.6 & 3.1 & 2 \\
\hline $\mathrm{NO}_{3}$ & 31 & 98 & 30 & 140 & 45 \\
\hline TDS & 370 & 580 & 690 & 680 & 1000 \\
\hline
\end{tabular}




\section{Water Supply}

The federally-owned well field produced water for the Laboratory and County water samples from the distribution system met all applicable EPA standards.

Municipal and industrial water supplies for the Laboratory and community were sampled at 15 deep wells, one gallery, and at five stations on the distribution system (Table E.X, Fig. 12). Detailed analyses are in Table E-XIII. Appendix A gives the federal and state standards and criteria for municipal water supplies. The maximum concentrations of chemical constituents from wells, gallery, and distribution system stations are compared to criteria in Table XXII.

Concentrations of arsenic $(0.5 \mathrm{mg} / l)$ and fluoride $(2.8 \mathrm{mg} / \mathrm{l})$ in water from well LA-1B and lead $(0.19$ $\mathrm{mg} / \boldsymbol{l}$ ) in water from well G-6 were at or above stan- dards for drinking water;' however, mixing with water from other wells reduces the concentrations to levels well within standards at points of use. Arsenic and fluoride in water from well LA-1B is naturally occurring in the aquifer. The high lead concentration in well G-6 is from wear on the pump resulting in finely divided particles of lead-containing brass in the water. The well was taken out of service in November 1978 and returned to service in June 1979. The well was taken out of service again in August as the well was pumping sand and the pump could not be adjusted to operate properly. It has since been removed for repairs.

TABLE XXIY

\section{MAXIMUM CHEMICAL CONCENTRATIONS IN WATER SUPPLY (cuncentrations in $\mathrm{mg} / \mathrm{l}$ )}

\begin{tabular}{|c|c|c|c|}
\hline Analysis & $\begin{array}{l}\text { Supply Wells } \\
\text { an Gallery }\end{array}$ & Distribution & $\begin{array}{c}\text { Standard or } \\
\text { Criteria }\end{array}$ \\
\hline $\mathrm{Ag}$ & $<0.001$ & $<0.001$ & 0.05 \\
\hline As & 0.05 & 0.01 & 0.05 \\
\hline $\mathrm{Ba}$ & $<0.5$ & $<0.5$ & 1.0 \\
\hline $\mathrm{Cd}$ & $<0.01$ & $<0.01$ & 0.010 \\
\hline $\mathrm{Cl}$ & 15 & 8 & 250 \\
\hline $\mathrm{Cr}$ & 0.02 & 0.008 & 0.05 \\
\hline $\mathrm{F}$ & 2.8 & 1.0 & 2.0 \\
\hline $\mathrm{Hg}$ & $<0.0005$ & $<0.0005$ & 0.002 \\
\hline $\mathrm{NO}_{3}$ & $<2$ & $<2$ & 45 \\
\hline $\mathrm{Pb}$ & 0.19 & $<0.01$ & 0.05 \\
\hline $\mathrm{Se}$ & $<0.005$ & $<0.005$ & 0.01 \\
\hline TDS & 588 & 262 & $i 000$ \\
\hline
\end{tabular}




\section{Nonradioactive Effluents}

Nonradioactive effluerts include airborne and liquid discharges. Airborne effluents from the beryllium fabrication shop; gasoline storage and combustion; power plant; gases and volatile chemicals; waste explosive burning; lead pouring operations; and dynamic testing did not result in any measurable or theoretically calculable degradation of air quality. A single NPDES permit covers 108 industrial discharge points and 10 sanitary sewage treatment facilities. This year 6 of the 10 sanitary sewage treatment facilities exceeded one or more of the NPDES limits (excluding flow rate limitations) in one or more months and less than $1 \%$ of all samples from the 108 industrial outfalls exceeded NPDES limits.

a. Airborne Discharges. Airborne particulate concentrations in the Los Alamos and White Rock areas are routinely measured by the New Mexico State Environmental Improvement Division. Table E-XXI summarizes these data for 1979 . The highest $24 \mathrm{~h}$ averages and annual averages are compared to the New Mexico Ambient Air Quality Standards for particulates in Table XXIII. Both the $24 \mathrm{~h}$ averages and annual geometric means are well within state standards. Although true 7 day and 30 day averages cannot be calculated, there is no indication that they would exceed state standards.

Particulate samples from samplers located throughout. and adjacent to Laboratory property have been collected monthly since June of 1979 for heavy metal analyses. Samplers are located at the Fenton Hill Geothermal Site, the LASL Administration Building (TA-3), Santa Fe, Bandelier National Monument, White Rock, TA-49, and TA54. This sampling program was initiated primarily to measure concentrations of nonradioactive elements in rir for comparison with standards and to determirie whether LASL emissions are making any contribution. The project will also provide background data on concentrations of nonradioactive elements in the Los Alamos area. Some difficulty in sample analysis has been encountered, so that no results from this program are yet available.

TABLE XXIII

\section{SUMMARY OF ATMOSPHERIC PARTICULATE CONCENTRATIONS IN LOS ALAMOS AND WHITE ROCK DURING 1979}

\begin{tabular}{|c|c|c|c|}
\hline & 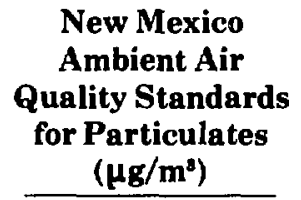 & $\begin{array}{c}\text { Los } \\
\text { Alamos } \\
\left(\mu \mathrm{g} / \mathrm{m}^{3}\right)\end{array}$ & $\begin{array}{c}\text { White } \\
\text { Rock } \\
\left(\mu \mathrm{g} / \mathbf{m}^{3}\right)\end{array}$ \\
\hline Maximum $24 \mathrm{~h}$ average & 150 & 77 & 113 \\
\hline Maximum 7 day average & 110 & $\cdots$ & $\ldots$ \\
\hline Maximum 30 day average & 90 & -.. & $\ldots$ \\
\hline Annual geometric mean & 60 & 35 & 35 \\
\hline
\end{tabular}


The samples will be analyzed for $\mathrm{Al}, \mathrm{Be}, \mathrm{Ca}, \mathrm{Cd}, \mathrm{Co}$, $\mathrm{Cr}, \mathrm{Cu}, \mathrm{Fe}, \mathrm{K}, \mathrm{Mg}, \mathrm{Mn}, \mathrm{Na}, \mathrm{Ni}, \mathrm{Pb}, \mathrm{Si}, \mathrm{Ti}$, and $\mathrm{Zn}$.

Airborne emission sources at LASL that are routinely checked include the beryllium shop, gasoline storage and combustion, TA-3 power plant, volatile chemical and gas usage, waste explosive burning, and dynamic experiments. These sources are discussed separately in the following paragraphs.

Beryllium concentrations in the stack gases from the beryllium shop are monitored by the Industrial Hygiene Group. However, for a large part of 1979 the stack gas sampling apparatus was broken, so no data are available on berylliun emissions for last year. In past years, stack gas concentrations have always been below the state ainbient air standard of $0.01 \mu \mathrm{g} / \mathrm{m}^{3}$, and total annual beryllium emissions have been about $20 \mathrm{mg}$. There is no reason to believe that there were substantial changes in emissions during 1979. The sampler is back in operation now, so data should be collected during 1980.

A large fleet of cars and trucks is maintained for the Laboratory complex by the Zia Company. During fiscal year 1979 , a total of $2.4 \times 10^{\circ} \boldsymbol{\ell}$ of gasoline were used by this fleet to cover $3.6 \times 10^{\circ} \mathrm{km}$. These figures represent changes of $-0.5 \%$ and $+1.7 \%$, respectively, indicating a slightly greater fuel economy than last year. Carbon monoxide, hydrocarbons, nitrogen oxides, sulfur oxides, and particulates are emitted during automobile operation. There are also gasoline evaporative losses associated with gasoline storage and vehicle refueling. By breaking down total gasoline usage among the size classes of vehicles and by applying the most appropriate EPA emissions factors ${ }^{13}$ to these data, air pollution emissions associated with maintenance and operation of the vehicle fleet (Table XXIV) were estimated. Estimated vehicle emissions are down drastically from last year because of reduced EPA emission factors for 1978 and 1979 vehicles.

The TA-3 power plant is fueled with natural gas and thus comes under state regulations for gas burning equipment. These regulations specify maximum allowable nitrogen oxide emissions but also contain a provision exempting facilities that have a heat input of less than $1 \times 10^{12} \mathrm{Btu} / \mathrm{yr} /$ unit. Heat input for the TA-3 power plant individual boilers during 1979 were $0.67 \times 10^{12} \mathrm{Btu}, 0.66 \times 10^{12} \mathrm{Btu}$, and $0.77 \times 10^{12}$ Btu. Total heat input for the power plant was $2.1 \times$ $10^{12} \mathrm{Btu}$ (about $14 \%$ less than last year), but inputs for the individual boilers were below the $1 \times 10^{12}$ Btu/yr exemption threshold.

Measured $\mathrm{NO}_{\mathrm{k}}$ (nitrogen oxides) concentrations in the power plant stack gas ranged from 36 to 46 ppm, which is about $20 \%$ of the standard that would apply if the heat input threshold were exceeded. Sulfur dioxide $\left(\mathrm{SO}_{2}\right)$ analyses of the stack gas are

\section{TABLE XXIV}

\section{ESTIMATES OF AIR POLLUTANT EMISSIONS ASSOCIATED WITH MAINTENAN( E ANI) OPERATION OF THE VEHIC'LE FIEET'}

\begin{tabular}{|c|c|c|}
\hline Pollutant & $\begin{array}{c}\text { Estimated } \\
\text { Amount } \\
\text { (metric tons) }\end{array}$ & $\begin{array}{c}\text { Change } \\
\text { From } 1978 \\
(\%)\end{array}$ \\
\hline (iasoline Evatporative losses & 29 & $+2 . \overline{1}$ \\
\hline Carbour Momoxide & 108 & -.49 \\
\hline Hodrociabuns & 9 & -57 \\
\hline Vitrogen ()xicles & 17 & -41 \\
\hline Silliur Oxides & 1.2 & +8.3 \\
\hline l'articulates. lixhaust & 0.7 & +17 \\
\hline Particulatess Tires & 1.4 & +17 \\
\hline
\end{tabular}


TABLE XXV

\section{RSTIMATES OF STAC K GAS FMISSIONS FROM THE TA-3 POWER PI.ANT}

\begin{tabular}{lc}
\multicolumn{1}{c}{ Pollutant } & $\begin{array}{c}\text { Estimated Amount } \\
\text { (metric tons) }\end{array}$ \\
\hline Sulfuroxides & \\
Hydrocarbons & $0.55)$ \\
(arbon monoxide & 0.91 \\
Particulates & 15.5 \\
Nitrogenoxides & 9.1 \\
& $: 319$
\end{tabular}

not performed routinely, but the sulfur content of the natural gas fed to the boilers is so low that it precludes any significant $\mathrm{SO}_{2}$ emissions. Table XXV shows estimated total power plant emissions for 1979, based on EPA emission factors ${ }^{13}$ for natural gas burning facilities. 'The apparent decrease in $\mathrm{NO}$ emissions from previous years' estimates is because the earlier estimates did not incorporate a load reduction factor to account for oper.tion of the brilers at about $60 \%$ of their design capacity.

The laboratory complex uses large quantities of various volatile chemicals and gases, some of which are released into the atmosphere by evaporation or exhatust. I'sing data from stock records, a table of patterns of chemical usage has been compiled ('Table E-XXII). On the basis of actual release data obt ained from compressed gas and volatile chemical users throughout the laboratory, estimates of emissions are in preparation.

During 1979 a total of $19865 \mathrm{~kg}$ of high explosives wastes vere disposed by open burning at the Laboratory. Estimates of emissions (Table XXVI) were made by using data from experimental work carried out by Mason \& Hangar-Silar Mason Co., Ine. ${ }^{14}$ Open burning of high explosives wastes is permitted by the New Mexico Air Quality Control regulations.

Dynamic experiments employing conventional explosives are routinely conducted in certain test areas at L.ASL and may contain quantities of potentially toxic metals, including beryllium, lead, and uranium. Some limited field experiments, based on aircraft sampling of debris clouds, provided information on the proportion of such materials
TABLE XXVI

\section{ESTIMATED EMISSIONS FROM BURNING OF EXPLOSIVE WASTES \\ (Using Data from Mason and Hanger- Silas Mason Co., Inc. ${ }^{(3)}$}

\begin{tabular}{|c|c|}
\hline Pollutant & $\begin{array}{l}\text { Estimated } \\
\text { Amount (kg) }\end{array}$ \\
\hline Carbon Monoxide & 155 \\
\hline Particulates & 358 \\
\hline Nitrogen Oxides & 600 \\
\hline
\end{tabular}

aerosolized. This information was employed to prepare estimates of oncentrations at the LASL boundary based on the current year's utilization of the elements of int erest. The results are presented in Table F-XXIII along with comparisons to applicable air quality regulations. The average concentrations are all less than $0.01 \%$ of applicable standards. The amount of material used in testing operations during 1979 was less than $50 \%$ of that used during the previous year.

\section{b. Liquid Discharges}

Nonradioactive liquid wastes are released from 108 industrial discharge points and 10 sanitary sewage treatment facilities subject to National Pollutant Discharge Elimination System (NPDES) requirements. The single NPDES permit for LASL issued by the EPA places specific effluent limits on 10 categories of industrial waste outfalls and 10 sanitary sewage treatment facilities. Tables E. XXIV and E-XXV summarize the effluent quality and compliance status of the sanitary and industrial waste outfalls, respectively.

This year two of the sanitary sewage outfalls met all limits, and two others (lagoons) exceeded only flow rate limits during winter months when they were frozen. The industrial outfalls exceeded one or more limit during 1979 less than $7 \%$ of the time. Eight of those responsible for the largest number of deviations are scheduled for already-funded corrective measures to be carried out in 1980-81.

The two radioactive waste treatment plants have the largest number of limits with which to comply, 
and those plants exceeded one or more limits in less than $3 \%$ of the samples taken. Details of the effluent quality from these two plants are given in Table E-
XXVI for nonradioactive (including several not regulated by the NPDES permit) and radioactive constituents.

\section{ENVIRONMENTAL EVALUATION}

\section{A. Radiation Doses}

Small incremental radiation doses above those recieved from natural and worldwide fallout background are received by Los Alamos County residents as a result of LASL operations. The largest estimated dose at an occupied location was 6.1 mrem or $1.2 \%$ of the Radiation Protection Standard. This estimate is based on boundary dose measurements of airborne and scattered radiation from the accelerator at $\mathrm{TA}-53$. Other minor exposure pathways, direct radiation from TA-18 and two unlikely food pathways may result in several $\mathrm{mrem} / \mathrm{yr}$ in isolated cases. No significant exposure pathways are believed to exist for radioactivity released in treated liquid waste effluents. The radioactivity is absorbed in alluvium before leaving LASL bounds.ries and some is transported offsite in stream channel sediments during heavy runoff. The total population dose received by residents of Los Alamos County was conservatively estimated to be 10.86 man-rem or about $0.41 \%$ of the 2665 man-rem received by the same population from natural radiation sources, and $0.34 \%$ of the population dose due to diagnostic medical exposure. As 110 significant pathways could be identified outside the County, the 10.86 man-rem dose also represents the population dose to inhabitants living within an $80 \mathrm{~km}$ radius of LASL who receive an estimated $13000 \mathrm{man}$ rem from background radiation. The average added risk of cancer mortality to Los Alamos residents from radiation from this year's LASL operations is 1 chance in 13000000 . This risk is much less than the 1 chance in 72000 from background radiation, which in turn is very small compared to the average annual New Mexico cancer incidence risk rate of 1 chance in 405. The EPA has estimated a verage lifetime risk for cancer incidence as 1 chance in 4 and for cancer mortality as 1 chance in 5 .

One means of evaluating the significance of environmental releases of radioactivity is to interpret the exposures received by the public in terms of doses that can be compared to appropriate standards and naturally present background. The critical exposure pathways considered for the Los Alamos area were atmospheric transport of airborne radioactive effluents, hydrologic transport of liquid effluents, food chains, and direct exposure to penetrating radiation. Exposures to radioactive materials or radiation in the environment were determined by direct measurements for some air- borne and waterborne contaminants and external penetrating radiation, and by theoretical calculation based on atmospheric dispersion for other airborne contaminants. Doses were calculated from measured or derived exposures utilizing models based on recommendations of the International Council on Radiation Protection (ICRP, see Appendix D for details) for each of the three following categories:

1. Maximum dose at a site boundary,

2. Dose to individual or population groupe where highest dose rates occur, and 
3. The whole body cumulative dose for the population within an $80 \mathrm{~km}$ radius of the site.

Exposure to airborne 'H (as HTO) was determined by actual measurements with background correction based on the assumption that natural and worldwide fallout activity was represented by the average data from the three regional sampling locations at Española, Pojoaque, and Santa Fe.

Exposures to ${ }^{11} \mathrm{C},{ }^{10} \mathrm{~N},{ }^{10} \mathrm{O}$, and ${ }^{11} \mathrm{Ar}$ from LAMPF were inferred from direct radiation measurements (see Sec. III.A.1). Exposure from "Ar released from the TA-2 stack was theoretically calculated from measured stack releases and standard atmospheric dispersion models.

Estimates of a maximum lung exposure to plutonium were calculated by subtracting the average concentration at the regional stations from the average concentration from the perimeter station with the highest measured plutonium concentration (Table XXVII).

The maximurn boundary and individual doses attributable to these exposures are summarized in Table XXVII with a comparison to the Radiation Protection Standards (RPS) for individual doses (see Appendix A).

All other atmospheric releases of radioactivity (see Table E-XX) were evaluated by theoretical calculations. All potential doses were found to be less than the smallest ones presented above and were thus considered insignificant.

Liquid effluents, as such, do not flow beyond the LASL boundary but are absorbed in alluvium of the receiving canyons; excess moisture is lost primarily by evapotranspiration. These effluents are monitored at their point of discharge and their behavior in the alluvium of the canyons below outfalls has been studied..$^{17-20}$ Small quantities of radioactive contaminants transported uring periods of heavy runoff have been measured in canyon sediments beyond the LASL boundary. Calculations made for the Final Environmental Impact Statement ${ }^{3}$ inclicate a maximum exposure pathway (eating liver from a steer that drinks water from and grazes in lower Los Alamos Canyon) to man from these canyon sediments results in a maximum 50 yr dose commitment of $0.0013 \mathrm{mrem}$ to the bone.

There are no known significant aquatic pathways or food chains to humans it the local area. Fruit, vegetable, honey, and fish sampling (see Sec.
III.A.5) has documented that any exposure attributable to LASL operations via those pathways is insignificant. A possible minor exposure pathway exists by eating venison from deer who cross into Laboratory property to graze and drink. The maximum dose calculated via this pathway is 3.9 $\mathrm{mrem} / \mathrm{yr}^{3}$ and is unlikely to occur.

As was stated in Sec. III.A.1, no measurements of external penetrating radiation at regional and perimeter stations in the environmental network indicated any discernable increase in radiation levels that could be attributed to LASL operations except those along State Road 4 north of LAMPF. The special TLD network at the Laboratory boundary north of TA-53 indicated a 21.7 mrem increase above natural background. Of this increase, 10.7 mrem was attributed to direct and scattered radiation from stored shield components and an opened beam stop area during accelerator maintenance in the fall at LAMPF. Based on orcupancy and shielding, this would contribute a 3.0 mrem dose to an individual working at the restaurant north of LAMPF. The other 11.0 mrem are attributed to activated air emissions from LAMPF. These airborne emissions would contribute a $3.1 \mathrm{mrem}$ dose to an individual working in the restaurant north of LAMPF for a total dose of 6.1 mrem which is $1.2 \%$ of the RPS for a member of the public.

Onsite measurements of above background doses were expected and do r.ot represent potential exposure to the public except in the vicinity of TA-18 on Pajarito Road. Members of the public regularly utilizing the DOE-controlled road passing by TA-18 would likely receive no more than $0.5 \mathrm{mrem} / \mathrm{yr}$ of direct gamma and neutron radiation. This value was derived from 1975 data $^{2 l}$ on total dose rates using 1979 gamma doses measured by TLDs and estimating exposure time by assuming a person made 15 round trips per week at an average speed of 40 mph past TA-18 while tests were being conducted. The onsite station near the Laboratory boundary at State Road 4 recorded a dose of $187 \mathrm{mrem} / \mathrm{yr}$. This is caused by a localized accumulation of ${ }^{137} \mathrm{Cs}$ on sediments transported from a treated effluent release point upstream. A maximum onsite dose to a member of the public from airborne effluents of $0.00055 \mathrm{mrem}$ was estimated for a person spending 4 $h$ at the Laboratory Museum while "Ar effluent dispersed from TA-2 passed over the Museum. The ${ }^{4} \mathrm{Ar}$ emissions from TA-2 and TA-53 could result in a 
TABLE XXVII

BOUNDARY AND MAXIMUM INDIVIDUAL DOSES FROM AIRBORNE RADIOACTIVITY

\begin{tabular}{|c|c|c|c|c|c|c|}
\hline \multirow[b]{2}{*}{ Isotope } & \multirow[b]{2}{*}{$\begin{array}{c}\text { Critical } \\
\text { Organ } \\
\end{array}$} & \multicolumn{2}{|c|}{$\begin{array}{c}\text { Maximum } \\
\text { Boundary Dose } \\
\end{array}$} & \multicolumn{2}{|c|}{$\begin{array}{c}\text { Maximum } \\
\text { Individual Dose }\end{array}$} & \multirow[b]{2}{*}{ \% RPS } \\
\hline & & Location & $\begin{array}{c}\text { Dose } \\
\text { (mrem/yr) }\end{array}$ & Location & $\begin{array}{c}\text { Dose } \\
\text { (mrem/yr) }\end{array}$ & \\
\hline${ }^{\circ} \mathrm{H}(\mathrm{HTO})$ & Whole Body & TA.54 & 0.043 & Airport & 0.0084 & 0.0017 \\
\hline${ }^{11} \mathrm{C},{ }^{19} \mathrm{~N},{ }^{18} \mathrm{O}$ & Whole Body & $\begin{array}{l}\text { Restaurant } \\
\text { N. of TA-53 }\end{array}$ & 11.0 & $\begin{array}{l}\text { Restaurant } \\
\text { N. of TA-53 }\end{array}$ & 3.1 & 0.62 \\
\hline${ }^{1} \mathrm{Ar}$ & Whole Body & $\begin{array}{l}\text { Boundary N. of } \\
\text { TA-2 Stack }\end{array}$ & 1.8 & $\begin{array}{l}\text { Apts. N. of } \\
\text { T'A-2 Stack }\end{array}$ & 1.0 & 0.2 \\
\hline${ }^{230} \mathrm{Pu}$ & Lung & TA-54 & 0.008 & Cumbres School & $0.008^{a}$ & 0.00053 \\
\hline
\end{tabular}

a For a 50-yr dose commitment, bone is the critical organ. A maximum individual would receive a 50-yr bone dose commitment of $0.51 \mathrm{mrem}$, which is $0.035 \%$ of RPS. 
TABLE XXVIII

\section{WHOLE BODY POPULATION DOSES TO RESIDENTS OF LOS ALAMOS COUNTY}

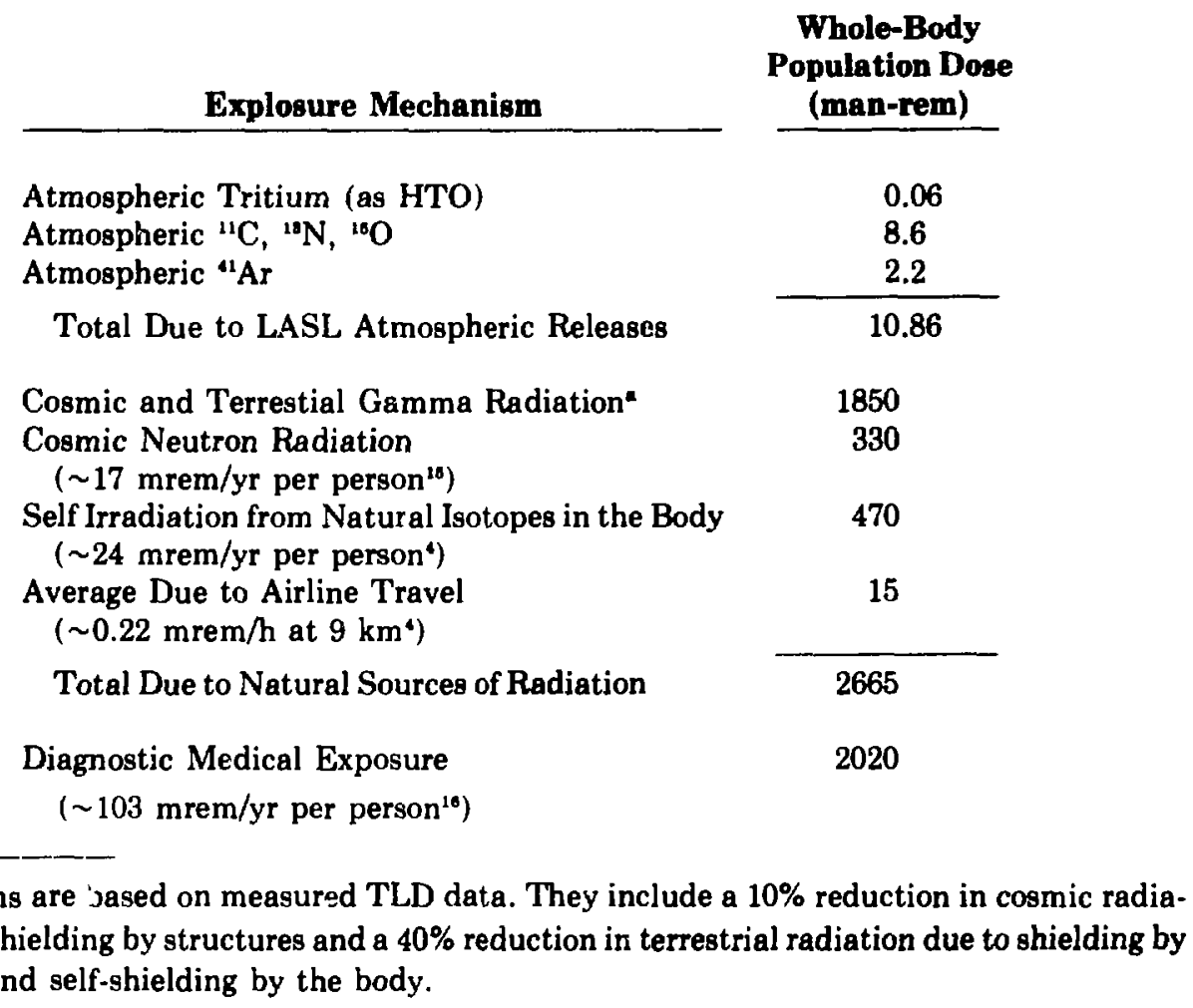

theoretically calculated annual regional (at Espanola) dose of $0.004 \mathrm{mrem}$.

Cumulative 1979 whole body doses to Los Alamos County residents attributable to LASL operations are compared to exposure from natural radiation and medical radiation in Table XXVIII. Population data are based on a Los Alamos County Planning Department estimate of 13300 residents in the Los Alamos townsite and 6300 in White Rock.

The calculated 8.6 man-rem from atmospheric ${ }^{12} \mathrm{C},{ }^{10} \mathrm{~N}$, and ${ }^{10} \mathrm{O}$ is probably high because it is subjec to many of the same uncertainties that caused boundary dose calculations to overestimate actua! doses. The whole-body population dose to the estimated 108000 inhabitants ${ }^{22}$ of the $80 \mathrm{~km}$ circle around Los Alamos because of LASL operations is estimated to be 10.86 man-rem, which is the popula- tion dose to Los Alamos County inhabitants. That is because other population centers are far enough away that dispersion, dilution, and decay in transit (particularly for ${ }^{11} \mathrm{C},{ }^{13} \mathrm{~N},{ }^{10} \mathrm{O}$, and ${ }^{11} \mathrm{Ar}$ ) make exposure undetectable and theoretically a very small fraction of the estimated 10.86 man-rem. By contrast, natural radiation exposure to the inhabitants within the $80 \mathrm{~km}$ circle is $12800 \mathrm{man}$-rem.

Thus, doses potentially attributable to releases of effluents contribute about $0.41 \%$ of the total dose received by Los Alamos County residents from natural radiation, about $0.54 \%$ to the same population from diagnostic medical radiation, and about $0.008 \%$ of the dose from natural radiation received by the population within an $80 \mathrm{~km}$ radius of the Laboratory. 
Since there is considerable interest in possible health effects from radiation doses to the public resulting from LASL operations, several risk estimates have been made. However, these calculations may overestimate actual risk as the NCRP ${ }^{23}$ has warned "risk estimates for radiogenic cancers at low doses and low dose rates derived on the basis of linear (proportional) extrapolation from the rising portions of the dose incidence curve at high doses and high dose rates... cannot be expected to provide realistic estimates of the actual risks from low level, low-LET (linear energy transfer) radiations, and have such a high probability of overestimating the actual risk as to be of only marginal value, if any, for purposes of realistic risk-benefit evaluation."

The ICRP estimates that the total stochastic risk of cancer mortality from uniform whole body irradiation for individuals is $1 \times 10^{-4}$ per rem, i.e., there is 1 chance in 10000 that an individual exposed to 1000 mrem of whole body radiation would develop a cancer. In developing risk estimates the ICRP has warned "radiation risk estimates should be used only with great caution and with explicit recognition of the possibility that the actual risk at low doses may be lower than that implied by a deliberately cautious assumption of proportionality. "24 Persons living in Los Alamos and White Rock received an average of $138 \mathrm{mrem}$ and 128 mrem, respectively, of whole body radiation from natural sources (including cosmic and terrestrial radiation with allowances for shielding, selfirradiation and cosmic neutron exposure, but excluding that radiation received from airline travel, luminous dial watches, building materials, etc.). Thus, the added cancer mortality risk due to natural radiation in 1979 was 1 chance in 72000 in Los Alamos and 1 chance in 78000 in White Rock. LASL operations contributed an average dose of $0.78 \mathrm{mrem}$ to individuals in Los Alamos and $0.08 \mathrm{mrem}$ to individuals in White Rock. These added risks amount to a conservative 1 chance in 13000000 in Los Alamos and 1 chance in 130000000 in White Rock of a cancer mortality due to LiSL activities. The average incidence is 1 chance in 405 each year that a person in New Mexico will contract a cancer from all causes. ${ }^{26}$ For Americans the average lifetime risk is a 1 in 4 chance of contracting a cancer and a 1 in 5 chance of dying from the disease. ${ }^{20}$ The Los Alamos and White Rock additional doses attributable to LASL operations are equivalent to the additional ex- posure a person would get from riding in a jet aircraft for 3.5 and $0.36 \mathrm{~h}$, respectively.

The additional exposure (which is likely overestimated) and subsequent risk to Los Alamos County residents are well within variations in natural exposure and risks in life that are accepted routinely by most people. For example, one study ${ }^{27}$ showed the annual dose rate on the second floor of single-family frame dwellings was $14 \mathrm{mrem} / \mathrm{yr}$ less than the dose rate on the first floor. Energy conservation measures, such as sealing and insulating houses and installing passive solar systems, are likely to contribute much larger doses to Los Alamos County residents than LASL operations because of increased radon levels inside the homes. The EPA has estimated the annual whole body dose to individuals from global fallout to be $4.4 \mathrm{mrem}$ of which $2.5 \mathrm{mrem}$ is due to ingestion of ${ }^{00} \mathrm{Sr} .{ }^{28}$

\section{B. Environmental Protection Programs at LASL}

\section{LERC/EEC Program}

In order to assist DOE to comply with requirements of the National Environmental Policy Act (NEPA), LASL has a Laboratory Environmental Review Committee (LERC). The membership consists of representatives from several Associate Directors offices, Financial Management, the Engineering Department, and the Health Division. The LERC has responsibility to review environmental assessments (EAs) and other environmental documents prepared for DOE by the Laboratory. Additionally, LERC identifies and reviews items of environmental interest that are generated by Laboratory activities or that affect the Laboratory programs and property. An Environ rental Evaluations Coordinator (EEC), based in the Environmental Surveillance Group (H8), assists LERC by coordinating with user groups, Health Division and the Engineering Department on development of environmental documents and providing input to project design at the earliest stage for appropriate environmental decision making.

Projects that may require an EA or EIS are screened by the EEC to determine what form of environmental documentation is necessary. When needed, various resource persons are identified by 
the EEC to assist in preparation of the draft environmental document for the proposed construction or programmatic project.

The EEC also coordinates input on environmental matters for other official documents and the Quality Assurance (QA) program (see next section). The EEC and the Environmental Surveillance Group representative to the QA program work with those responsible for construction and/or programmatic activities to assure that proper envirorimental considerations are made during the assessment and that they are implemented in the QA progra: 2.

\section{Quality Assurance Program}

LASL has a Quality Assurance (QA) program ${ }^{20}$ for engineering, construction, modification, and maintenance of DOE-owned facilities and installations. The purpose of the program is not only to minimize chance of deficiencies in construction, but also to improve cost effectiveness of facilities' design, construction, and operation, and to protect the environment. QA is implemented from inception of design through completion of construction by a project team approach. The project team consists of individuals from the DOE program division, DOE Albuquerque Operations and Los Alamos Area Offices, LASL operating group(s), LASL Engineering Department, design contractor, inspection organization, and construction contractor. Under the project team approach each organization having responsibility for some facet of the project is likewise responsible for its respective aspects of the overall QA program. For example, it is the inspection organization's responsibility to provide assurance that the structures, systems, and components have been constructed or fabricated in accordance with the approved drawings and specifications.

Laboratory representatives are responsible for coordinating reviews and comments from all groups with a vested interest in the project. In particular, the Environmental Surveillance Group reviews proposed new construction, maintenance activities, and modifications to existing facilities to minimize any environmental degradation. Consideration is given to the present condition of the site (soils, geology, ground water, surface water, air quality, archeology, flora, fauna, drainage features, archeological resources, etc.), environmental conse- quences of the proposed project (airborne effluents, liquid effluents, industrial waste, solid waste, noise levels, traffic patterns, etc.), and environmental impact assessment (air, water, land, visual, noise, odor, biota, etc.).

\section{Archeology}

Protection of archeological sites at LASL (mandated by several Congressional acts and Executive Order 11593) is also part of the QA program. A proposed location for a new facility is checked to determine if there are any archeological sites in the area. An attempt is first made to adjust siting so as to preserve the site. If alternative siting is not feasible, then the site is excavated to gain knowledge about it and recover artifacts before it is destroyed. The decision as to which course to follow is based on the value of the archeological site, on the availability of alternative locations for the new facility, and on the programmatic impact if the new facility were not built at that location.

A survey of more than 450 archeological sites in LASL environs was made between March 1973 and July 1975 . This survey of the pre-Columbian Indian ruins is summarized in a report, ${ }^{30}$ which is used during construction planning to avoid damage to such sites if possible, or to provide the lead time necessary to conduct required salvage archeology. Several unique sites were recommended for registration as national historic sites and formal nomination procedures are underway. This will ensure their preservation for future generations by establishing formal responsibility and authority to protect the sites.

Twenty additional archeological sites were located at LASL in 1979 and have been added to the inventory of historic sites. During the year one preColumbian ruin (LA-4718) was excavated. It proved to be an exceptionally interesting site with a $2 \mathrm{~m}$ deep kiva and plans are being made to put a roof over the kiva to preserve it. ${ }^{\text {at }}$

Two local boys made an important and interesting find of two 15th century pottery vessels (Fig. 18) sealed with lime plaster. ${ }^{32}$ The boys brought the pots to LASL where a series of nondestructive tests were made. X-rays showed how one pot rim fitted over the other pot rim. Neutron radiography revealed feathery-looking contents inside. 


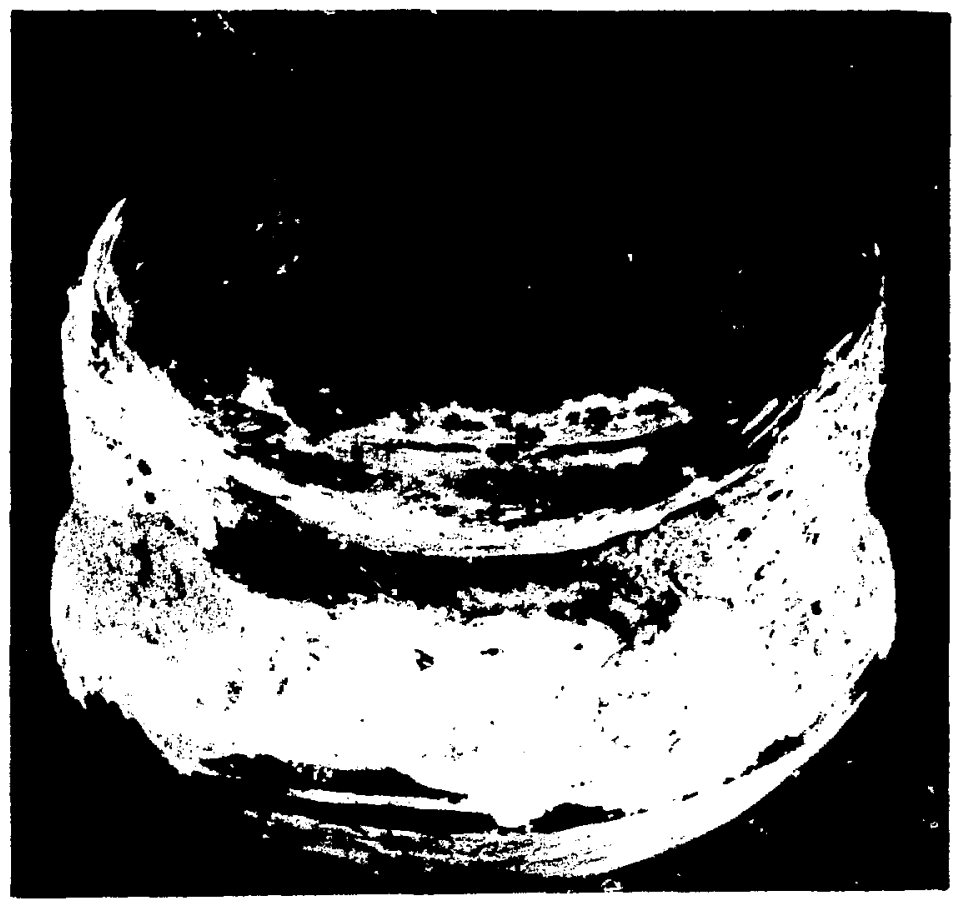

Fig. 18.

Two Indian pots sealed with the only known use of lime plaster found so far in the Southwest.

The pots were scrutinized by drilling a small hole, about $3 \mathrm{~mm}$ in diameter, through the top pot. An optical borescope, a slender metallic rod with a light at one end and an eyepiece at the other, was inserted. Inside, feathers of several different colors, ranging from reddish to white to soft orange, could be seen. Yucca plant fibers, twisted into cords, also came into view. The feathers and other samples, small bits of which were pulled from the pot with a fine wire, have been sent to the Smithsonian Institute for ornithological and other analyses. The feathers have been tentatively identified as belonging to the macaw, which would make them imported; they could also be from an indigenous species like the flicker. The pots have been placed in the Bradbury Science Hall by the finders.

Five log cabins, which date from the early years of this century, are located within LASL boundaries. All are deteriorating rapidly, and the Historic Preservation Branch of the National Park Service is preparing a preservation plan for the structures. Borings of the logs will be taken to estimate construction dates by dendrochronology. Serious damage to one of the log cabins, the Anchor Ranch lce House, was done by vandals during the summer of 1979. The entire north wall was pulled over-presumably by someone who wanted some well-cured poles.

\section{Decontamination and Decommissioning Work}

During the spring of 1979 , old tritium handling equipment was removed from building TA-35-2. To monitor for possible airborne release of tritium during decontamination operations, two special air sampling stations were established. The samplers were located within $3 \mathrm{~m}$ of the building in which the decontamination took place. Atmospheric tritiated water vapor (HTO) concentrations measured by 
these two samplers ranged from 29 to $270 \times 10^{-12}$ $\mu \mathrm{Ci} / \mathrm{m} \ell$ anc averaged $114 \pm 78 \times 10^{-12} \mu \mathrm{Ci} / \mathrm{m} \ell$ or about ten times normal onsite HTO levels. The controlled area CG for HTO is $5 \times 10^{-6} \mu \mathrm{Ci} / \mathrm{m} \ell$ and uncontrolled area $\mathrm{CG}$ is $2 \times 10^{-7} \mu \mathrm{Ci} / \mathrm{m} \ell$ (see Appendix A). НТO measured in ambient air outside the facility could have been from the decontamination operation and/or from off-gassing of the tritium handling equipment. Concentrations measured, however, were three to four orders of magnitude less than the appropriate CGs.

Work continued in 1979 at DP site (TA-21), in decontamination of buildings that were former plutonium handling facilities. Once decontaminated, the buildings will be used for other research activities. In conjunction with these activities, several underground structures (manholes, sewer lines, etc.) next to the buildings were removed along with associated contaminated soil. Soil was removed to the extent practicable, since it was not possible to remove ali contaminated soil without threatening building foundations. The location and extent of soil decontamination was carefully documented for the time when the buildings are removed and the soil decontamination can be completed.

Radioactively contaminated air washers are being removed from TA-35-7 and disposed of at LASL's Radioactive Materials Disposal Site (TA-54). Possible contaminants in the washers were ${ }^{80} \mathrm{Sr},{ }^{137} \mathrm{Cs}$, fission products, and low level transuranics. Four months into the project no indication of any airborne radioactivity from the operation has been seen on filters from two special air samplers located within $10 \mathrm{~m}$ of the facility.

\section{Related Environmental Studies}

The Environmental Science Group (LS-6) at LASL conducts research and experimental studies under auspices of the DOE. Some of the research programs conducted by LS- 6 complement routine monitoring and research conducted by the Environmental Surveillance Group ( $\mathrm{H}-8)$ in providing a better understanding of the ecosystem surrounding LASL in relation to the Laboratory's operations. Following are highlights of several of these research programs.
1. Fire Ecology at Bandelier National Monument [L. D. Potter (Plant Ecologist, Biology Department, University of New Mexico) and T. S. Foxx (LS-6)]

The role of fire in the ecosystem has been of increasing interest. For nearly 70 years a policy of total fire suppression was followed by Bandelier National Monument and the U.S. Forest Service. In 1976 a study was funded by the National Park Service to provide baseline data for a fire management plan. The study included a determination of fire frequency prior to start of the total fire suppression policy and plant succession after fire. Fire frequency was determined by fire scar dating and plant succession by examining areas known to have been burned. This baseline study was near completion in June 1977, when the La Mesa Fire burned $62 \mathrm{~km}^{2}$ and swept over established plots. The area burned was under management of Bandelier National Monument, Santa Fe National Forest, and LASL.

To determine how this fire affected areas of known fire history, plots were examined to determine the amount of foliar singeing sustained during the La Mesa Fire. Resulting data showed that for the La Mesa Fire, the longer the interval since the last fire, the more foliar damage. Areas which had not burned within the last 27 years showed nearly complete tree kill. Analysis of fire scarred trees revealed a fire frequency averaging 17 years and ranging from 8 to 27 years. Alteration of the 8 to 27 year fire cycle was probably due to three factors: 1) settlement of the area hegan about 1894 , one year after what appears to have been the last major fire; 2) extensive logging in the late 1800 s and 1900 s virtually cleared some areas of trees; 3) by 1920 the Bandelier National Monument and adjacent forested land were under a policy of total fire suppression which has existed to this day. Thus, the holocaustic nature of the La Mesa Fire can be attributed to over 80 years of fuel load accumulation. This study provides a case for more frequent fires. ${ }^{33}$

To protect valuable archeological resources from severe erosion and to maintain integrity of the watershed, the area was successfully seeded by air with six native grasses. A number of parameters related to germination of the grasses was examined under studies funded by the Eisenhower Consortium and LASL. ${ }^{8.34}$ Success of germination varied from an average of $27 \%$ to a high of $97 \%$. The density and 
foliage cover of slender wheatgrass and sheep fescue is expected to help natural regeneration of ponderosa pine as well as to bring wildlife into the burned areas.

2. Status of Flora in the NERP /T. S. Foxx and G. D. Tierney (Consulting Botanists, LS-6)]

The Endangered Species Act of 1973 (Public Law 93-205) mandated location of habitats of plant species in danger of extinction on state and federal lands. In 1976 the Los Alamos National Environmental Research Park (NERP) was established with the ultimate goal of providing a study area "to contribute to the understanding of how man can best live in balance with nature while enjoying the benefits of technology." ${ }^{30}$ Under this mandate a preliminary study ${ }^{36}$ to provide information as to the location of possible endangered and threatened species within the NERP was initiated August 1977.

This initial study was confined to Water and Mortandad Canyons and adjacent mesas as representative of the larger $\left(111 \mathrm{~km}^{2}\right)$ NERP. These areas were selected because they contained the greatest variety of habitats and provided a collecting transect dissecting the NERP. Each area was surveyed seasonally. Collections of all species were inade initially and the occurrence of certain species was recorded. This provided not only information about species' diversity and distribution in each canyon, but also a more precise habitat description.

Among the flora in the area, one species, grama grass cactus (Pediocactus paprycanthus) that is on the Smithsonian Endangered and Threatened Species List, was found. It was located in an area ad. jacent to the NERP. The population was small and various human activities are contributing to deterioration of its habitat.

Fourteen plants on the New Mexico State Protected List were located. Only the Larkspur Violet (Viola pedatifida) appears to be of any significance. It is a rare peripheral, which has been collected infrequently in New Mexico. A small population was found and its habitat could be damaged by logging or herbicides. All other species on the protected list were ennumerated for informational purposes. None of those plants were considered rare or in need of protection from Laboratory activities, other than to preserve some natural flora of the area.
At the present time 280 species representing 62 taxonomic families were collected or noted in Mortandad, Effluent and Water Canyons. A number of these species had not previously been reported for the area. Much of the area surveyed was heavily disturbed due to activities prior to and since establishment of the Laboratory. There were various stages of plant succession. The upper portion of Water Canyon burned in the 1977 La Mesa Fire and now shows post-fire succession, increased size in many plant species, and heavy browsing of most shrubs.

This continuing study is designed to provide a data base so that LASL may comply with existing federal and state laws concerning protection of plant species. This data base will furnish necessary information for floristic dynamic studies.

\section{Changes in Quality of Surface Water} Related to La Mesa Fire, 1977 [W. D. Purtymun (H-8) and Howard Adams (H-7)]

Quality of water data was collected from a surface water station near the Bandelier National Monument Headquarters in Cañon de los Frijoles prior to and after the wildfire burned about $26 \mathrm{~km}^{2}$ of the drainage area above the station. ${ }^{37}$ The burn brought about a slight increase in calcium, bicarbonate, chloride, fluorides and total dissolved solids in base flow at the station (Fig. 19). Those constituents in base flow have shown a general decline in concentration with time as fire debris and ash is removed from the drainage area and channel with continued runoff.

Samples of base flow and storm runoff were collected in Cañon de los Frijoles and Capulin Canyon. About $3 \mathrm{~km}^{2}$ of the drainage area at Capulin Canyon was burned by the La Mesa Fire in 1977. Samples of base flow and storm runoff in Cañon de los Frijoles indicated barium, calcium, iron, bicarbonate, manganese, lead, phenol, and zinc concentrations were elevated in storm runoff when compared to base flow (Fig. 20) concentrations. Analyses of base flow and storm runoff in Capulin Canyon indicated barium, calcium, iron, and manganese concentrations were elevated during runoff events when compared to base flow concentrations. Bicarbonates varied, but showed no statistically significant trends. Phenols and lead were below limits of detection. Presence of phenols in runoff is from decay of 


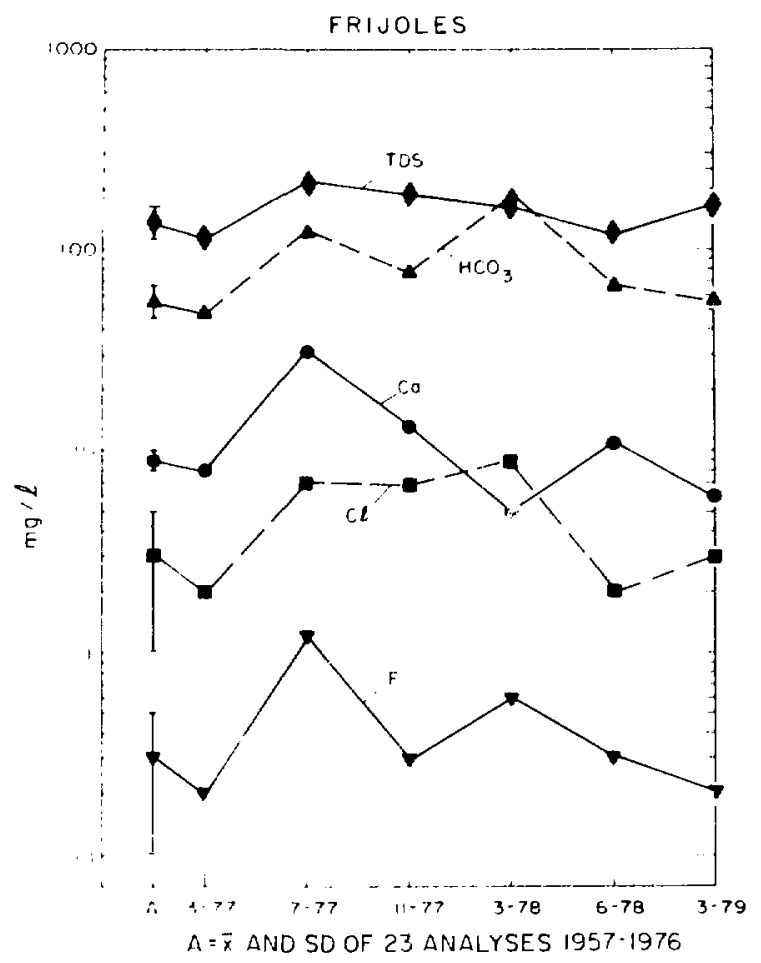

Fig. 19.

Variation in chemical constituents in base flow in Cañon de los Frijoles prior to and after the La Mesa Fire.

vegetation in the drainage area. Lead concentrations found in runoff in Cañon de los Frijoles could possibly be from automobile emissions as it was not detected in the runoff events in Capulin Canyon. The Monument Headquarters in Cañon de los Frijoles is subject to heavy vehicle traffic, while Capulin Canyon is remote, with no vehicle access.

\section{Fenton Hill Site (TA-57) Surface and} Ground Water Quality [W. D. Purtymun and R. W. Ferenbaugh (H-8)]

LASL is currently evaluating the feasibility of extracting thermal energy from hot dry rock (HDR) geothermal reservoirs at its Fenton Hill Site (TA57). The concept involves drilling two deep holes into HDR, connecting these holes by hydraulic fracture, and bringing thermal energy to the surface by circulating water through the system.

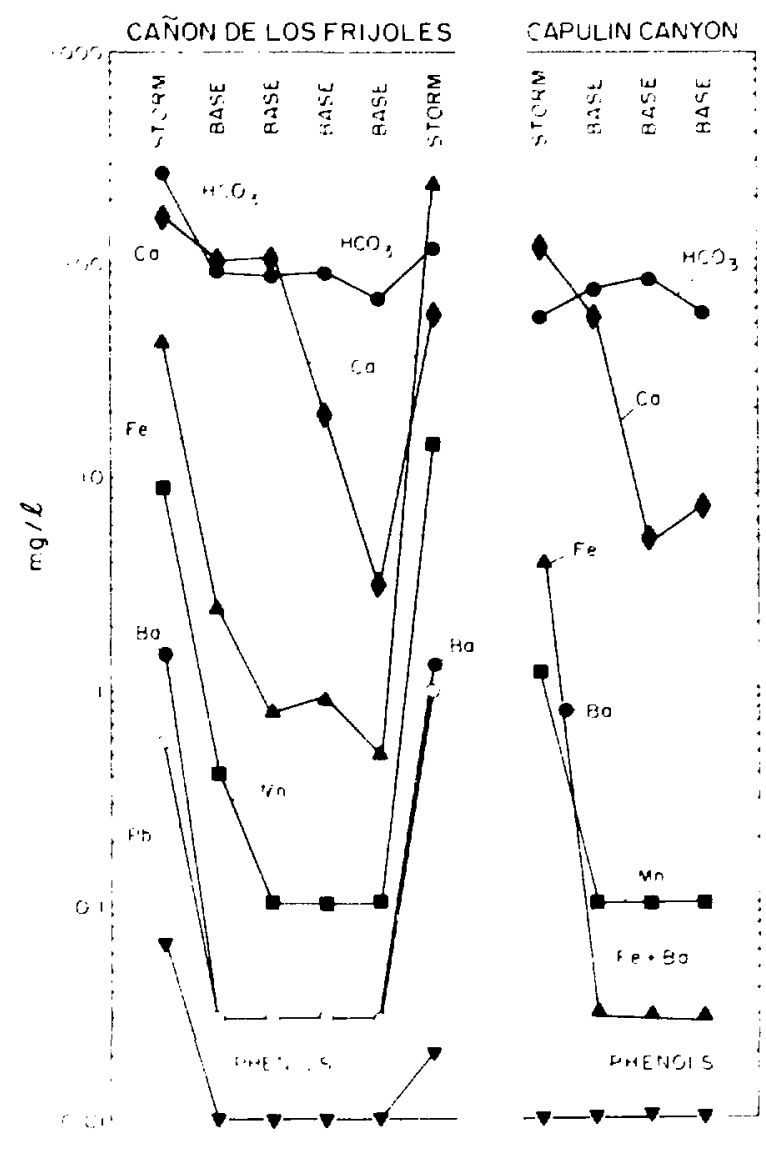

Fig. 20.

Variation in chemical constituents in base flow and storm runoff in Cañon de los Frijoles and Capulin Canyon after the La Mesa Fire.

The chemical quality of surface and ground waters in the vicinity of TA-57 $(\approx 30 \mathrm{~km} \mathrm{~W}$ of Los Alamos, Fig. 21) has been determined for use in geohydrology and environmental studies. The results of past studies and detail data have been reported elsewhere. ${ }^{38-4 s}$ Table E-XXVII summarizes the 1979 data on the chemical quality of water for nine surface water stations, four water supply locations, two springs along the Jemez Fault, one spring discharging from recent volcanics, and one abandoned well. Water quality has varied slightly; however, the variations in quality are normal due to seasonal fluctuations.

Three ponds at the site coniain water used in drilling operations and water used in the experimental 


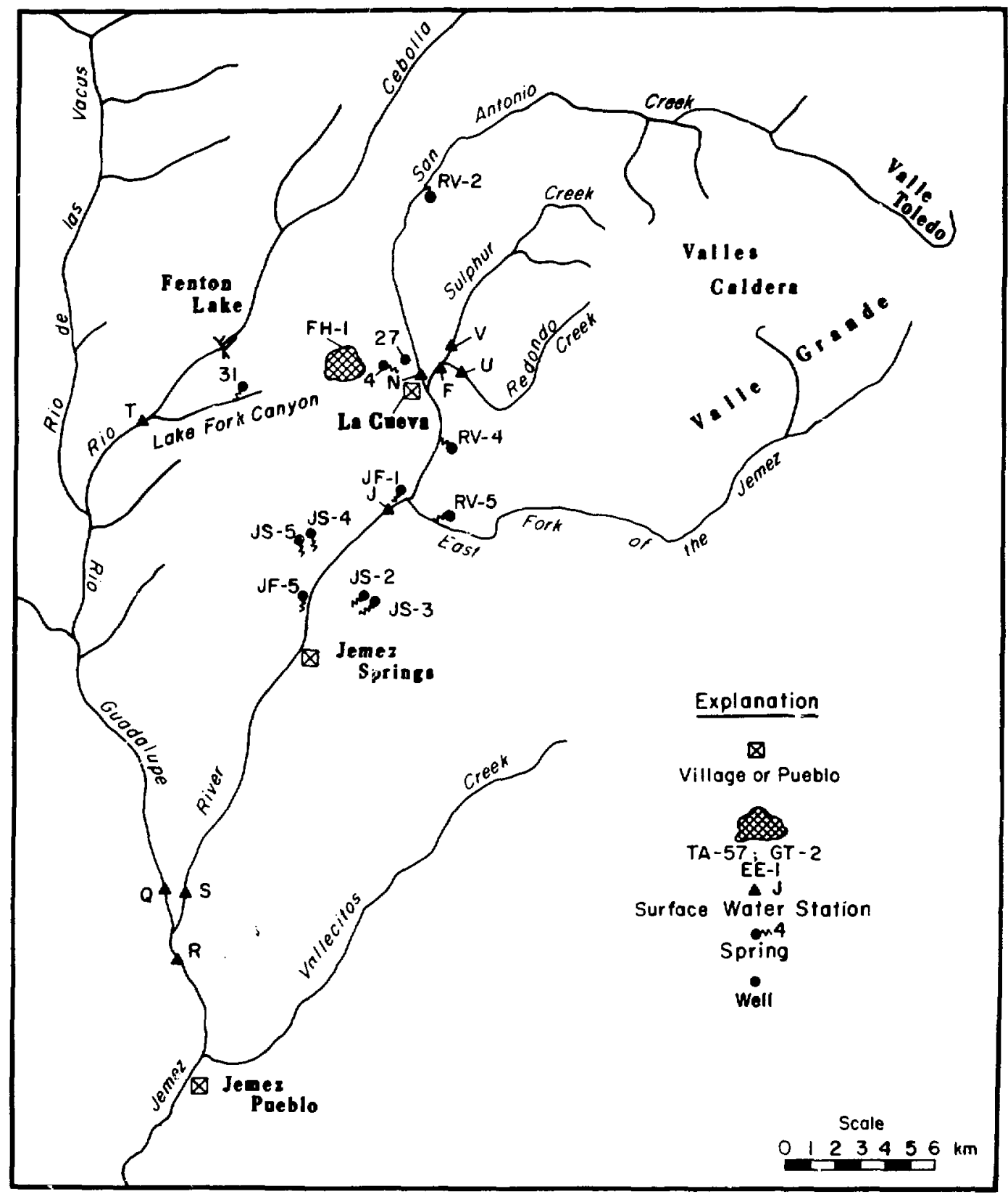

Fig. 21.

Water sampling locations in vicinity of Fenton Hill Geothermal Site (TA-57). 
TABLE XXIX

\section{AVERAGE CONCENTRATIONS OF SELECTED \\ ELEMENTS IN PONDS AND IN SURFACE \\ AND GROUND WATER AT TA-57 \\ (concentrations in $\mathrm{mg} / \mathrm{l}$ )}

\begin{tabular}{|c|c|c|c|c|c|}
\hline Locations" & As & B & Cd & $\mathbf{F}$ & $\mathbf{I} \mathbf{i}$ \\
\hline Pond 1 ('TA-5T) & 0.094 & 4.4 & $<0.001$ & 3.1 & $2.63 ;$ \\
\hline Pond $2(T A-57)$ & 0.091 & 4.1 & $<0.001$ & 2.2 & 2.93 \\
\hline Pond :3 (TA-5T) & 0.108 & 4.2 & $<0.001$ & 3.6 & 2.79 \\
\hline Surface Water (9 [ocations) & 0.024 & 0.3 & $<0.00)^{2}$ & 0.8 & $<0.3$ \\
\hline Water Supply (4 Locations) & 0.003 & $<0.05$ & $<0.001$ & 0.5 & $0.01: 3$ \\
\hline Springs (2.Jemez Fault) & 0.088 & 9.4 & $<0.001$ & 3.1 & 8.20 \\
\hline Spring (1 Volcanics) & $<0.001$ & $<0.05$ & $<0.001$ & 1.1 & 0.02 \\
\hline Abandoned Well (1) & $<0.001$ & $<0.005$ & $<0.001$ & 1.0 & $<0.1)^{2}$ \\
\hline
\end{tabular}

"See Tuhln EXXXVII and Fig. 21 for location of sampling sites.

loop in the dry hot rocks at a depth of about $3000 \mathrm{~m}$ below land surface. The water in the ponds is highly mintralized ( 890 to $5100 \mathrm{mg} / \ell$ of TDS). Certain elements present in the ponds are of interest because of monitoring requirements specified in the National Pollutant Discharge Elimination System permit. 'These are arsenic, boron, cadmium, fluoride, and lithium. Table XXIX presents the concentrations of these elements in the ponds and waters monitored in the area. Discharge from the ponds is into a dry canyon and its rate is regulated so that it infiltrates into alluvium of the dry canyon within $300 \mathrm{~m}$ of the ponds. The average concentrations of arsenic, boron, fluoride and lithium at surface water stations is elevated at stations $R$ and $S$ as the result of discharge from thermal and mineral springs at stations JS-1 and JS-5."4

Water from the supply well at the Fenton Hill Site (FH-1) was analyzed for chemical and radiochemical constituents to determine if the water is acceptable for municipal or domestic use according to EPA standards c: criteria. A comparison of the analytical results to standards show that the water is well below limits set for municipal use (Table XXX).
5. Effect of Rototilling on the Distribution of ${ }^{137} \mathrm{Cs}$ in Trinity Site Soil [T. E. Hakonson and G. C. White (LS-6)!

Soils and sediments are the major repositories of radioactive and stable elements released to the environment. Thus, processes that redistribute soils and sediments also redistribute environmental contaminants, particularly those contaminants that are tightly bound to soil or sediment. For example, wind and water erosion of soil and sediment causes redistribution of environmental plutonium, americium, and ${ }^{137} \mathrm{Cs} .{ }^{48-61}$

Contaminants that are suspended by wind and water deposit on land or on biological surfaces that include the lung. Thus, methods that reduce contaminant concentrations on land surfaces where erosion occurs may be beneficial in reducing risks incurred through inhalation and ingestion of particles.

This report presents results of an experiment to determine changes in spatial distribution of ${ }^{137} \mathrm{Cs}$ in nuclear fallout contaminated soil after vigorous, shallow, mechanical rototilling The scale of the experiment and tilling method were chosen to simulate 


\section{TABLE XXX}

\section{CHEMICAL AND RADIOCHEMICAL CONCENTRATIONS IN WATER FROM SUPPLY WELL AT TA-57}

\begin{tabular}{|c|c|c|}
\hline & $\begin{array}{c}\text { Supply Well } \\
\text { FH-1 } \\
\end{array}$ & $\begin{array}{c}\text { Standard or } \\
\text { Criteriat } \\
\end{array}$ \\
\hline \multicolumn{3}{|l|}{ Chemical (mg/s) } \\
\hline $\mathrm{Ag}$ & $<0.001$ & 0.05 \\
\hline As & $<0.001$ & 0.05 \\
\hline $\mathrm{Ba}$ & $<0.5$ & 1.0 \\
\hline $\mathrm{Cd}$ & $<0.01$ & 0.010 \\
\hline $\mathrm{Cl}$ & 19 & 250 \\
\hline Cr & $<0.002$ & 0.05 \\
\hline $\mathbf{F}$ & 0.3 & 2.0 \\
\hline $\mathrm{Hg}$ & $<0 .(0005$ & 0.002 \\
\hline $\mathrm{NO}_{3}$ & 1.5 & 45 \\
\hline $\mathrm{Ph}$ & 0.002 & 0.05 \\
\hline Se & $<0.005$ & 0.01 \\
\hline 'TIS & 244 & 1000 \\
\hline \multicolumn{3}{|l|}{ Radiochemical (pCi/ $\ell$ ) } \\
\hline${ }^{3} \mathrm{H}$ & $<0.6$ & 20 \\
\hline${ }^{187} \mathrm{Cs}$ & $<80$ & $206=$ \\
\hline${ }^{290} \mathrm{Pu}$ & $<0.03$ & 7.5 \\
\hline${ }^{238} \mathrm{Pu}$ & $<0.04$ & 7.5 \\
\hline Gross alpha & 2.3 & 5 \\
\hline Total uranium ${ }^{b}$ & 1.9 & 1800 \\
\hline
\end{tabular}

\footnotetext{
aEnvironmental Protection Agency's National Interim Primary Drinking Water Regulations (see Appendix A).

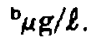

conditions normally used in establishing and preparing a small garden plot.

Concentrations of ${ }^{137} \mathrm{Cs}$ in soil as a function of depth and tilling summarized in Table XXXI. In the 0 to $7.5 \mathrm{~cm}$ depth profile, the arithmetic mean concentration of ${ }^{137} \mathrm{Cs}$ and coefficient of variation (in parentheses) based on a sample size of 130 was 1.94 $\mathrm{pCi} / \mathrm{g}(0.87)$ before tilling and $1.76 \mathrm{pCi} / \mathrm{g}(0.53)$ after tilling. In the 7.5 to $15 \mathrm{~cm}$ profile, concentrations averaged $0.08 \mathrm{pCi} / \mathrm{g}(2.8)$ before tilling and 0.38 $\mathrm{pCi} / \mathrm{g}(1.9)$ after tilling.

Differences in concentrations of ${ }^{137} \mathrm{Cs}$ between upper and lower profiles before tilling were significant (p $<0.01$ ) and differed by a factor of about 25 . The concentration decrease after rototilling of about $10 \%$ in the surface $7.5 \mathrm{~cm}$ of soil was not significant at the $95 \%$ confidence level (i.e., $p=0.289$, $t$-test with correction for unequal variances). In contrast, the concentration of ${ }^{137} \mathrm{Cs}$ increased significantly $(p<0.01)$ in the lower profile reflecting transfer of ${ }^{137} \mathrm{Cs}$ from the surface to the lower profile.

The data was also highly skewed, particularly for the 0 to $7.5 \mathrm{~cm}$ depth before tilling and the 7.5 to 15 $\mathrm{cm}$ profile after tilling. This skewness is reflected by the variability in the concentrations. 
TABLE XXXI

\section{CONCENTRATION OF ${ }^{17}$ CS IN SOIL AS A FUNCTION OF DEPTH AND TILLING AT TRINITY SITE}

\begin{tabular}{|c|c|c|c|c|c|}
\hline \multirow{2}{*}{$\begin{array}{l}\text { Depth } \\
(\mathrm{cm})\end{array}$} & \multirow[b]{2}{*}{ Treatment } & \multirow{2}{*}{$\begin{array}{l}\text { Number of } \\
\text { Samples }\end{array}$} & \multicolumn{3}{|c|}{$\begin{array}{c}{ }^{137} \text { ('s Concentration } \\
\text { (p( } \mathrm{i} / \mathrm{h})\end{array}$} \\
\hline & & & Mean & $1 \mathrm{~s}$ & Median \\
\hline$(1-7.5)$ & Before tilling & $1: 30$ & 1.94 & 1.69 & 1.311 \\
\hline 0.7 .5 & After tilling & $1: 30$ & 1.76 & 0.94 & $1.6(1)$ \\
\hline 7.5 .15 & Hefore tilling & $1: 30$ & $0.08: 3$ & $0.2: 3$ & 0.025 \\
\hline 7.5 .15 & After tilling & $1: 30$ & 0.38 & 0.73 & 0.13 \\
\hline
\end{tabular}

A significant change in variability of the data was noted after tilling. Variability in concentrations decreised significantly ( $p \leq 0.01$, Moses test of extreme reactions $)^{A 6}$ in the surface $7.5 \mathrm{~cm}$ of soil after tilling with a corresponding reduction in skewness. However, variability increased significantly in the 7.5) (1) $15 \mathrm{~cm}$ profile samples after tilling.

The relatively minor effect of tilling on the concentrations of ${ }^{137} \mathrm{C} s$ in the surface $7.5 \mathrm{~cm}$ was surprising considering the vigorous tilling effort. This result implies that shallow rototilling of soil is only slightly effective in reducing surface concentrations of contaminants strongly fixed to soil. Although concentrations of ${ }^{137} \mathrm{Cs}$ in the 7.5 to $15 \mathrm{~cm}$ profile increased by a factor of four, the difference in concentiation between upper and lower profiles was still a factor of about five.

Procedures such as soil removal and mechanical tilling to reduce concentrations of potentially hazardeus crontaminants from surface soil must be evaluated to justify costs and ensure compatability with intended objectives. Results of this study demonstrate that shallow rototilling was ineffective in reducing surface soil concentrations of ${ }^{3 n} \mathrm{Cs}$. Thus, the effectivencss of shallow rototilling in reducing soil contaminant transport across land surfaces by wind and water would be minimal, assuming that ${ }^{137} \mathrm{Cs}$ and soll particle size relationships were not greatly altered. However rototilling did reduce variability in ${ }^{137} \mathrm{Cs}$ concentrations in surface soils. Thus, considerable benefit could be realized by designing sampling programs in similarly treated areas, since sample size requirements, and thus, costs are related as a square function to variability. ${ }^{32}$

6. LA/NERP Elk Studies $\mid$ G, C. White and T. E. Hakonson (1.S. . F)

Fik bıotelemetry studies were continued during the past year in the Los Alamos/National Environmental Research Park (LA/NERP) area through cooperative research with Bandelier Vational Monument and New Mexico State University. Twelve elk were trapped and radio collared during January on Bandelier National Monument in the habitat created by the La Mesa Fire. Three additional animals were trapped and radio collared west of Bandelier National Monument on U.S. Forest Service lands during late March and April, also on habitat created by the La Mesa Fire.

Elk were lured into modified Clover traps using alfalfa as bait. The traps were set and checked morning and evening. In addition, radios which had been placed on elk and deer and later returned were used to monitor the traps. The radios were wired to the trap door so that when the trap was sprung, the radio was shut off. Thus as long as the radio signal could be picked up, the trap was open.

Captured elk were sedated with a horse sedative to ease handling of the animal. Radio collared animals are located on a weekly basis, or more frequently. Locations are plotted on a base map, and coded for machine processing. Weekly fixes for each animal 
are plotted by computer on a map of the Jemez Mountains.

The severe winter of 1978.79 did not seem to cause much mortality of the elk wintering on the La Mesa Fire burn area. One animal was captured which appeared severely malnourished, and it later died. However, other animals captured during the winter all survived, and all of the animals which had been radio collared during the previous winter survived. A summary of mortalities (or presumed mortalities) is given in Table XXXII. Of the four elk known dead, two have died from natural causes, and two bulls (both legal size) were killed by hunters. One bull is believed to have been porched, and one radio failed. Otherwise the remainin: 23 animals are still being tracked.

The importance of the La Mesa Fire burn area as a elk wintering hahitat was demonstrated during the winter of 1978-79. The animals radio collared during the previous winter resided in the area rather than in areas where they had been captured. The shift in winter habitat was particularly swift, taking place during a period of a week immediately after a severe December snow storm which left up to $1 \mathrm{~m}$ of snow on the ground. An additional factor may also have been hunter pressure on U.S. Forest Service lands, forcing animals onto unhunted National Park Service lands.

The bull elk have traveled extensively about the Jemez Mountains, while the cows have tended to stay in southeastern portions of the area. Bulls 161 , 202, 720 , and 820 all summered more than $24 \mathrm{~km}$ from their capture locations, while all the cows sum. mered within $24 \mathrm{~km}$ of their capture locations. Bull 201. was particularly interesting because he was killed mure than $65 \mathrm{k} n \mathrm{n}$ from the area where he spent the winter. Areas where these bulls spent the summer are not any higher in elevation or more remote than the area used by the cows.

\section{Computer Generated Mlovies to Display Biotelemetry Data [G. C. White (LS-6)]}

The typical biotelemetry study generally results in a large amount of data that is difficult to interpret and display because of a lack of effective presentation methods. Biotelemetry data are actually three dimensional: $x$ and $y$ coordinates, and time. Thus, three dimensional methods of viewing the data would generally facilitate in erpretation because any method of collapsing three dimensions into two results in some loss of information. Use of computer generated $16 \mathrm{~mm}$ movies to portray biotelemetry dat a has been explored to permit the time dimension of the data to be viewed in correct evolutionary sequence. A romputer generated movie of the elk movements described in Section IV.C. 6 has been made, and a movie of coyote movements on the Idaho National Environmental Research Park (INERP) has been made. For the elk, 3000 observations on 30 elk are summarized by the movie, while over 5000 observations for 5 coyote are summarized in the INERP movie.

The present version of these movies consists of a colored base map with a small square moving on the map to depict animal movements. Color intensity of the square is enhanced when the location of the animal is based upon an actual radio-location; whereas movement of the square at normal color intensity represents linear interpolation between actual radio fixes.

The time dimension is also displayed on the map. In the elk movie, the month and year are displayed simultaneously with animal movements data. Coyote data was taken intensively over $24 \mathrm{~h}$ periods, so a 24 h time line is used to show the time of day.

A permanent trace of all movements of one individual during an observation period can be obtained to facilitate identification of areas of frequent use and rough home range sizes. Data from multiple animals cen also be displayed simultaneously to examine interactiuns between individuals, and sex and age classes as a function of season and habitat. Individuals or groups of animals (stratified by age or sex) can be distinguished by color of the squares. Movements of individual animals are not permanently traced due to the clutter that would result.

8. NERP Climatology Data [F. G. Fernald and D. A. Dahl (H-8)!

An automated meteorological tower network is being developed by the Environmental Surveillance Group (H-8) to provide meteorological data for environmental assessments, emergency response at atmospheric releases of pollutants, and climatological characterization. This includes future demands NERP will have for meteorological data in support of plant and animal life studies. 
TABLE XXXII

STATUS OF RADIO COLLARED ELK AS OF NOVEMBER 9, 1979

\begin{tabular}{|c|c|c|c|c|}
\hline $\begin{array}{l}\text { Radio } \\
\text { Frequency }\end{array}$ & $\begin{array}{l}\text { Age at } \\
\text { Capture }\end{array}$ & Sex & $\begin{array}{l}\text { Date of } \\
\text { Capture }\end{array}$ & Sitatus \\
\hline$|i j|$ & ('alf & $M$ & $2 / 2: 3 / 78$ & Alive \\
\hline 211.2 & ('alf & $\mathrm{M}$ & $: 3 / 19 / 78$ & Killed by hunter $1(1 / 7 !)$ \\
\hline 2811 & Aclult & $\mathrm{F}$ & $5 / 4 / 78$ & Alive \\
\hline $29 ! 2$ & Arlult & $\mathrm{F}$ & $2 / 10 / 78$ & Alive \\
\hline$: 31: 3$ & ('alf & F & $1 / 28 / 78$ & Alive \\
\hline איאוא & Goarlingr & $\mathrm{M}$ & $2 / 16 / 78$ & killed by humer $5 /$ ix \\
\hline (ilit & Artuli & $\mathbf{F}$ & $2 / 10 / 78$ & Alive \\
\hline$(i ; i)$ & Adult & $\mathbf{F}$ & $1 / 25 / 78$ & Alive \\
\hline $7: 31$ & $(a)$ & . & $2 / 21 / 78$ & Killed by lightning \\
\hline ilit & Adult & $\mathbf{F}$ & $2 / 18 / 78$ & Alive \\
\hline 77 & $($ all & $\mathrm{F}$ & $1 / 26 / 78$ & Alive \\
\hline $7 ! 11$ & call & $\mathbf{F}$ & $2 / 1: 1 / 78$ & Alive \\
\hline$x \cdot 11$ & $l^{\prime a l f}$ & M & $2 / 14 / 78$ & Alive \\
\hline S:1:3 & Aclult & $\mathrm{F}$ & $1 / 21 / 78$ & Alive \\
\hline$x+11$ & Arlult & $\mathrm{F}$ & $2 / 8 / 78$ & Alive \\
\hline $17: 3$ & l alf & M & $1 /: 3 / 79$ & Alive \\
\hline 211 & ('all' & $\mathrm{F}$ & $1 / 5 / 79$ & Alive \\
\hline 26$)^{2}$ & ralf & $F$ & $1 / \pi / 79$ & Alivo \\
\hline$:\{: 3: 3$ & ('all & $F$ & $1 / 9 / 79$ & Alive \\
\hline$: 3: 30$ & Vearling & F & $1 / 10 / 79$ & Radion lailute' \\
\hline 375 & Adult & $F$ & $1 / 10 / 79$ & Alive \\
\hline$: 348$ & Adult & F & $: 3 / 28 / 79$ & Died of malnut rition $/ / 7$ ! \\
\hline$(115)$ & ('all' & $\mathrm{M}$ & $1 / 14 / 79$ & Alive \\
\hline $.47 \overline{7}$ & Ardult & $\mathbf{F}$ & $1 / 11 / 79$ & Alive \\
\hline 190 & ('alf & $\mathrm{M}$ & $1 / 18 / 79$ & Alive \\
\hline sifiti & Calf & $F$ & $1 / 19 / 79$ & Alive \\
\hline$(i))^{3}$ & Y'earling & M & $1 / 19 / 79$ & l'resumed poachod T/is \\
\hline $701: 3$ & Adult & $\vec{F}$ & $4 / 15 / 79$ & Alive \\
\hline 7201 & Aclult & $\mathbf{M}$ & $4 / 16 / 79$ & Alive \\
\hline
\end{tabular}

Microprocessor controlled meteorological towers automatically preprocess and record measurements that include temperature, wind speed, wind direction, solar radiation, dewpoint temperature, humidity, and rainfall. The systems are capable of operating on solar power zlone. Emphasis has been placed on accumulating an accurate data base from which accident assessments and climatological summaries can be readily drawn.

Meteorological data are currently collected and recorded at the Occupational Health Laboratory $(\mathrm{OHL})$ and the active waste disposal site. A trans-

portable tower as well as additional permanent installations are planned in order to provide data representative of the entire Laboratory area.

The microprocessor controlled data system is programmed to sample each sensor 256 times every 15 minutes. The data are then written to cassette tape as an eighty character record which includes a header identifying the station, the data and time, plus 23 data channels. These data channels are apportioned between means and standard deviations. If the mean values are sampled from 16 sensors, then the standard deviations of 7 sensors can be recorded 
to fill the 23 data channels. If fewer sensors are monitored, more channels will be available to record standard deviations. Preprocessing greatly reduces the amount of data that must be recorded. A year's data from a single installation is reduced to a manageable 104340 octal records of 80 characters each. Up to 15 days of data can be accumulated on the cassettes before they have to be retrieved. After checking for obvious recording or sensors errors, the data is written to the Computer Center's "Common File System" where it can be accessed by any potential LASL user.

The "state of the art" design utilizing low power CMOS technology, provides a microprocessor controlled data system that requires between 0.5 and 1.0 watt depending on the actual installation. The system operates on batteries that can be charged with either AC line or solar power. Since fully charged batteries will keep the systems alive for up to two weeks, they are essentially independent of power outages.

Emphasis has been placed on developing a data base that provides accurate, readily accessible meteorological data. Software to generate tabular and graphical daily summaries has been developed. Figure 22 presents a daily summary of the OHL tower and ground station data for December 2, 1979. The lower three panels show the horizontal windspeed and direction, and the vertical wind speed on the tower $21 \mathrm{~m}$ above the surface. The shaded area represents \pm 1 standard deviation about the 15 min means.

The center panel shows the tower temperature (20 $\mathrm{m}$ above the surface), ground station temperature (1 $m$ above the surface), and ground station dewpoint temperature. The solid line is the ground station temperature, the shading shows the departure of the tower temperature from the ground station temperature, and the dashed line indicates dewpoint temperature. The remaining three panels present the net solar radiation on a horizontal surface, precipitation and relative humidity, and atmospheric pressure.

This day was selected as it very clearly shows the diurnal patterns affecting Los Alamos in absence of strong synoptic scale systems. Between midnight and 6 a.m., $2 \mathrm{~m} / \mathrm{s}$ drainage flow prevailed from the northwest. The flow was quite smooth as evidenced by the narrow standard deviation ranges in the horizontal and vertical wind components. This was expected under the stable $+0.2^{\circ} \mathrm{C} / \mathrm{m}$ temperature lapse rate recorded at that time. As the day progressed, solar heating of the surface reversed the vertical temperature gradient, and the mixing and dispersal properties of the atmosphere increased as is apparent from the increased standard deviations of the wind components. The wind shifted from the northwest to northeast, and then continued to turn clockwise, first due to local southeast upslope flow along the Jemez Mountains, and then due to the regional southerly flow up the Rio Grande Valley. By late afternoon, the mixing layer deepened and momentum mixdown added a component of the upper level westerlies to the flow. By $1800 \mathrm{~h}$ the wind had completed its full $360^{\circ}$ diurnal clockwise rotation and was again downslope out of the northwest. The boundary layer was again thermally stable, and the dispersion properties of the atmosphere were again suppressed.

Future plans call for expanding the automated tower network to three or four additional installations plus possible reinstrumentation of a $100 \mathrm{~m}$ tower. These data will provide excellent source for developing dispersion wind roses and other types of climatological summaries. As the data base expands. software will be developed to provide these climatological summaries on weekly, monthly, seasonal, and yearly bases. This meteorological data base can be easily interrogated to provide data for specially tailored analyses as required for NERP and other Laboratory investigations.

\section{Special Study of Radionuclides from} LAMPF Lagoons [R. W. Ferenbaugh and W. D. Purtymun (H-8)]

Cooling system leaks at the Los Alamos Meson Physics Facility (LAMPF) discharge water with activation product radionuclides, primarily ${ }^{3} \mathrm{H},{ }^{\top} \mathrm{Be}$, and ${ }^{22} \mathrm{Na}$, into the lagoons below the facility. Samples of water, sediments, and transpirate from trees adjacent to the effluent stream from the lagoons have been collected every 1 to 1.5 months since the effluent began flowing in the Spring of 1979. The purpose of this sampling program is to ascertain the extent to which radionuclides are being dispersed from the lagoons. Figure 23 shows locations of the sampling sites relative to the lagoons and to Los Alamos Canyon. Between sites 2 and 3, the discharge stream drops from the plateau on which the 


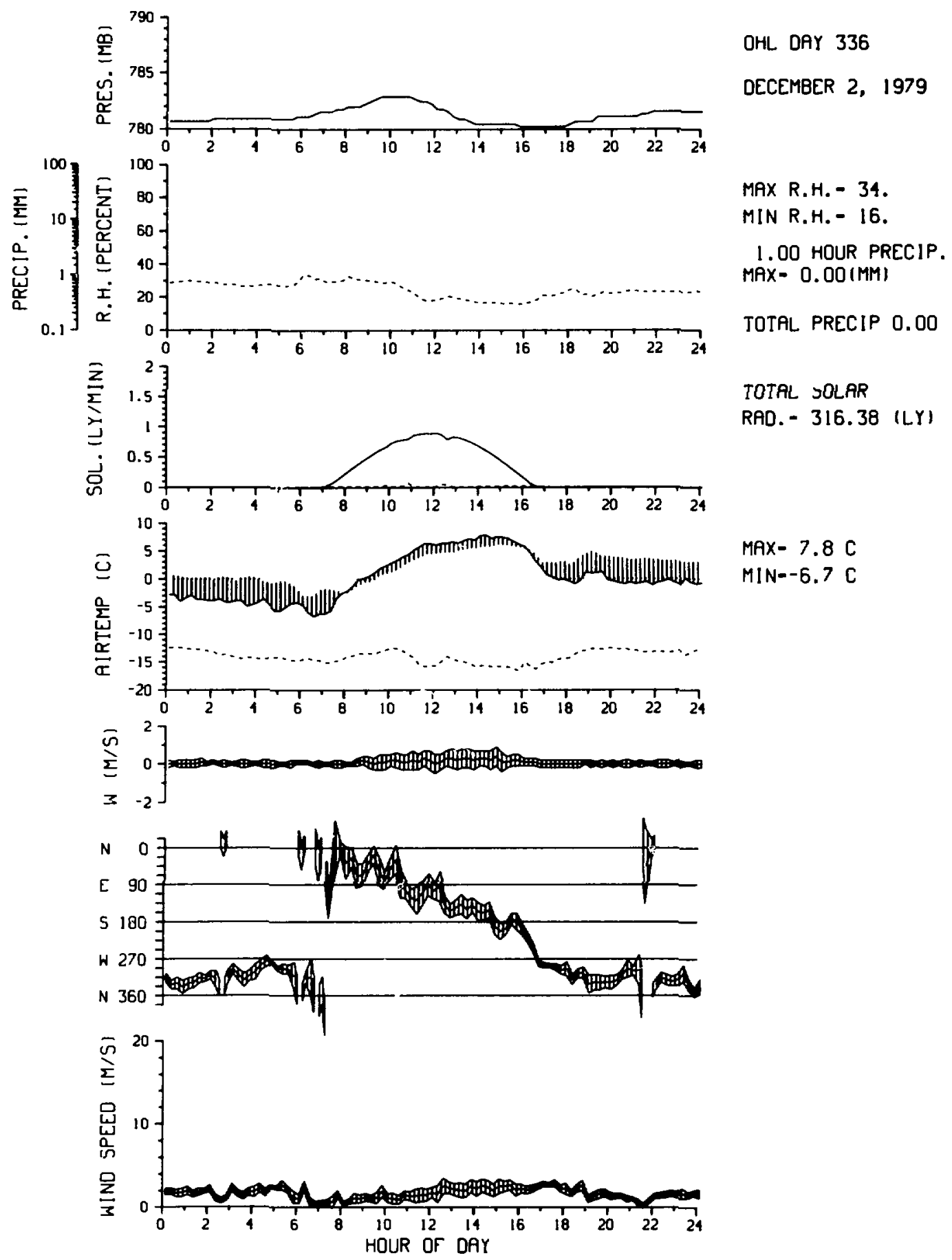

Fig. 22.

Summary of meteorological data from the OHL tower and ground level station for December 2,1979 . 


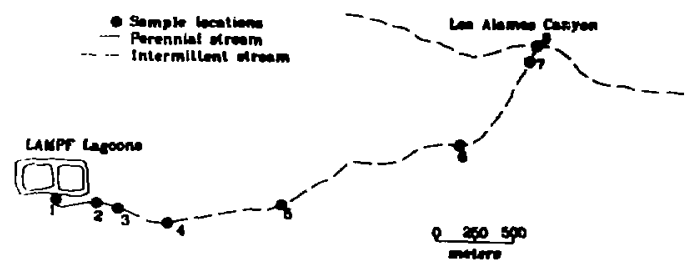

Fig. 23.

Sampling locations in vicinity of LAMPF lagoons.

lagoons are located into a side canyon that eventually connects with Los Alamos Canyon between sites 6 and 7 . Surface water is found below site 4 only during heavy runoff events. A summary of analytical results obtained from the samples collected is presented in Table XXXIII. These data show that radionuclide concentrations decrease with progression down the canyon. Data from individual analyses seem to indicate that there is continuing accumulation of radionuclides at sites 1 through 4 with time, but this is uncertain due to the few number of samples so far analyzed. Transpirate from pinon and juniper trees located on stream banks at sites 2 through 4 show somewhat elevated tritium content as HTO. In general, the data show that while there has been some dispersal of radionuclides down the canyon into which the discharge occurs, there has been no detectable dispersion beyond the point at which the discharge stream sinks into alluvium.

TABLE XXXIII

\section{ANALYTICAL RESULTS OF SAMPLES TAKEN BELOW LAMPF LAGOONS}

\begin{tabular}{|c|c|c|c|c|}
\hline & $\begin{array}{c}\text { No, of } \\
\text { Analyses }\end{array}$ & 'H & TPe & ${ }^{22} \mathbf{N a}$ \\
\hline \multicolumn{5}{|c|}{ Water (pCi/l) } \\
\hline Station 1 & 5 & $7.93 \pm 3.05 \times 10^{8}$ & $152000 \pm 137000$ & $2310 \pm 947$ \\
\hline Station 2 & 5 & $7.73 \pm 2.92 \times 10^{8}$ & $357000 \pm 326000$ & $2290 \pm 982$ \\
\hline Station 3 & 4 & $7.23 \pm 2.85 \times 10^{B}$ & $33000 \pm 46700$ & $2070 \pm 1030$ \\
\hline Station 4 & 3 & $6.15 \pm 1.73 \times 10^{5}$ & $39300 \pm 32100$ & $1400 \pm 757$ \\
\hline Station 8 & 2 & $0.02 \pm 0.02 \times 10^{6}$ & $75 \pm 21$ & $3 \pm 6$ \\
\hline \multicolumn{5}{|c|}{ Sediment ( $\mathrm{pCi} / \mathrm{g})$} \\
\hline Station 1 & 3 & $7.91 \pm 2.04 \times 10^{8}$ & $2580 \pm 2980$ & $2.2 \pm 0.6$ \\
\hline Station 2 & 5 & $8.27 \pm 2.56 \times 10^{8}$ & $5010 \pm 4530$ & $5.9 \pm 2.7$ \\
\hline Station 3 & 5 & $7.32 \pm 2.67 \times 10^{8}$ & $2770 \pm 5280$ & $1.9 \pm 2.1$ \\
\hline Station 4 & 5 & $4.55 \pm 2.94 \times 10^{\mathrm{s}}$ & $439 \pm 455$ & $1.5 \pm 0.8$ \\
\hline Station 5 & 5 & $0.90 \pm 1.58 \times 10^{8}$ & $148 \pm 331$ & $0.5 \pm 0.7$ \\
\hline Station 6 & 5 & $0.03 \pm 0.04 \times 10^{B}$ & $0.7 \pm 0.9$ & $0.01 \pm 0.04$ \\
\hline Station 7 & 4 & $0.01 \pm 0.06 \times 10^{8}$ & $0.6 \pm 0.6$ & $0.01 \pm 0.05$ \\
\hline Station 8 & 4 & $0.05 \pm 0.14 \times 10^{8}$ & $0.7 \pm 0.9$ & $0.03 \pm 0.03$ \\
\hline \multicolumn{5}{|c|}{ Transpirate $(\mathrm{pCi} / \ell)$} \\
\hline Station 2 & 3 & $3.47 \pm 0.61 \times 10^{8}$ & $483 \pm 375$ & $29 \pm 21$ \\
\hline Station :3 & 4 & $2.70 \pm 1.00 \times 10^{8}$ & $708 \pm 1550$ & $129 \pm 248$ \\
\hline Station 4 & 7 & $0.97 \pm 0.83 \times 10^{8}$ & $30 \pm 526$ & $5 \pm 62$ \\
\hline Station 5 & 5 & $0.00 \pm 0.02 \times 10^{8}$ & $914 \pm 2350$ & $8 \pm 63$ \\
\hline Station 6 & 4 & $0.01 \pm 0.04 \times 10^{8}$ & $250 \pm 465$ & $-20 \pm 29$ \\
\hline Station 8 & 3 & $0.00 \pm 0.01 \times 10^{6}$ & $667 \pm 1170$ & $0 \pm 20$ \\
\hline
\end{tabular}


10. Evaluation of Transuranic Waste Management Methods [L. J. Walker and W. R. Hansen (H8)1

Studies and evaluation of various alternatives for ultimate disposal of trensuranic (TRU) wastes is part of the ongoing waste management programs at LASL. TRU wastes at LASL are buried at six previously used waste areas, and buried and retrievably stored at currently used areas. By October 1980, a document detailing various options for disposition of these wastes will be prepared. Total estimated volume of TRU wastes $(>10 \mathrm{nCi} / \mathrm{g})$ is about $21200 \mathrm{~m}^{3}$, with about $2300 \mathrm{~m}^{3}$ estimated to be combustibles and about $7800 \mathrm{~m}^{3}$ to be metals. Among alternatives being evaluated for future disposition of the wastes are: 1) continue present prac(ices; 2) engineered-in-place improved barriers, such as additional earth and riprap cover; and, 3) exumation and retrieval, followed by some processing. Processing options include combustion, electropolishing, compaction, slurrying with cement paste, and simple repackaging without additional processing. Ultimate disposal considerations include deep pit burial at LASL or transfer to a federal repository when such a facility is available. Following review of this alternatives document, a decision will be made as to which of the many options will be evaluated in detail.

Several LASL groups are participating in the project. Included are WX-4 (a group in the Design Engineering Division) which is doing engineering and cost estimation work; the Health Physics Group $(\mathrm{H}-1)$ which is evaluating health risks associated with each alternative; the Waste Managemeni Group $(\mathrm{H}-\tau)$, which is doing inventory and source term defïnition work, the Environmental Studies (iroup (LS-6) which is involved with environmental transport methodology and modeling; and the Environmental Surveillance Group ( $\mathrm{H}-8)$ which is coordinating annd managing the project and developing a environmental surveillance plan.

The environmental surveillance plan details longrange sampling and evaluation of environmental media in and around active and previously used waste burial sites. The surveillance plan includes documentation of possible migration of wastes, comparisons of the data over prolonged time periods, and assurance that these areas are being managed and maintained in an environmentally acceptable manner. The plan will be applied to the retired waste sites and will provide for periodic sampling, analysis, and evaluation over the period of institutional control of these sites.

11. An Automated Transuranic Assay System for Soils [J. W. Nyhan, G. Trujillo, and B. J. Brennon (LS-6), and J. M. Crowell (H-1)]

Assaying soil and tuff samples containing low concentrations of transuranics currently requires time consuming, costly, and highly specialized analytical procedures. Currently, soil samples are dissolved in concentrated acid solutions and then passed through an ion exchange resin to achieve chemical separation. The sample is then electroplated onto a metal disk and assayed for transuranics using alpha spectrometry techniques. These procedures take several weeks and cost about $\$ 200$ per sample. An automatic transuranic assay system for soils (ATASS) to reduce the time and expense of analyzing transuranics in soil and tuff samples from radioactive shallow land burial sites has been developed. The ATASS simultaneously measures the low-and high-energy gamma spectrum $(0$ to $200(\mathrm{keV})$ of the components of soils and crushed givologic materials. An evaluation of the spectrum leads to quantitative identification of the transuranic sample constituents.

The counting sys ' $m$ of ATASS includes two germanium detectors that simultaneously assay a sample. The intrinsic germanium (IG) detector consists of a hyperpure germanium crystal with a thin metal semiconductor surface barrier entry window. The IG crystal is mounted in a cryostat, which has a thin beryllium window and a cooled field effect transistor. This detector has excellent photon peak resolution in the 0 to $200 \mathrm{keV}$ range with a total active detector area of $21 \mathrm{~cm}^{2}$ and a crystal thickness of $7 \mathrm{~mm}$. In order to also assay for high energy (200 to $2000 \mathrm{keV}$ ) gamma emitters with ATASS, a coaxial Ge(Li) detector was added to the system. The second detector has a right angle detector-dewar configuration and a total active volume of $125 \mathrm{~cm}^{3}$. These two detectors are interfaced with analog to digital converter multiplexers, pulse amplifiers, high voltage power supplies, a multichannel analyzer, and a minicomputer. 
The ATASS is mounted in a sample changer constructed to accept specially designed plastic sample containers. The sample changer consists of a lead lined wheel which is mounted vertically in the center of an aluminum framework (Fig. 24). The wheel has 20 evenly spaced sample holder positions. A small motor mounted in the center of the wheel allows it to turn and position a sample between the two detectors. The wheel holds the plastic sample containers which were designed to hold approximately $25 \mathrm{~g}$ of soil or tuff. The lid of the sample container is less than 1-mm thick and faces the IG detector (where low energy gamma emitters are assayed), whereas the bottom of the sample container is twic as thick as the lid and faces the $\mathrm{Ge}(\mathrm{Li})$ detect : for high energy gamma emitter assays.

Although additional system characterizations work is still needed, preliminary indications are that ATASS is a very effective, inexpensive radionuclide assay system for waste management research. The sensitivity of the IG detector is demonstrated by uncontaminated tuff samples spiked with weapons grade plutonium and americium standard solutions to mimic ineld samples with activity levels of 50 $\mathrm{pCi} / \mathrm{g}$. There is good peak resolution in the low energy $L \mathrm{x}$-ray region ( 0 to $20 \mathrm{keV}$ ) and the spiked sample spectra are distinct from the natural background of the sample, which defines peaks of naturally-occurring elements such as ${ }^{210} \mathrm{~Pb},{ }^{10} \mathrm{~K}$, and thorium.

The ATASS system was calibrated for ${ }^{241} \mathrm{Am}$ detection and plutonium calibration work was initiated. Coefficients for converting counts per second to $\mathrm{pCi}{ }^{241} \mathrm{Am} / \mathrm{g}$ have been determined for the 59.537 $\mathrm{keV}$ gamma ray and for the Am $\mathbf{x}$-rays (Table XXXIV). Furthermore, the ratios of $x$-ray intensities to gamma ray intensity were determined so that the

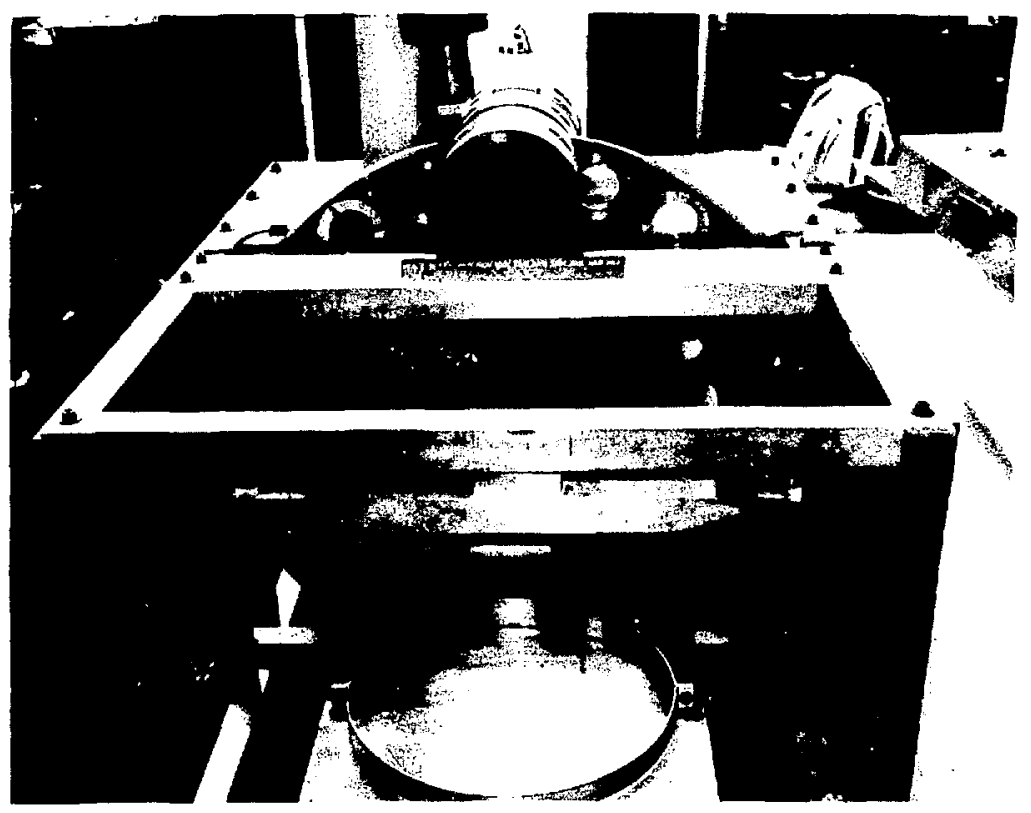

Fig. 24.

Sample changer for ATASS. 
americium contribution of the $x$-rays can be stripped from the spectra for plutonium analysis. We have also examined linearity of response of the IG detector to varying low radionuclide concentrations and have found that the IG detector does respond linearly with increased concentrations of Am placed in sample containers (Table XXXV). Results of similar experiments with weapons grade plutonium are shown in Table XXXVI; however, the large variation between replicate plutonium assays in this experiment preclude any conclusions about linearity of response for plutonium at this time. We currently expect to measure activities as low as $5 \mathrm{pCi} \mathrm{Pu} / \mathrm{g}$ and $0.05 \mathrm{pCi}{ }^{241} \mathrm{Am} / \mathrm{g}$ with maximum sample counting times of $4.5 \mathrm{~h}$.

TABLE XXXIV

RAIIONUCLIDE SENSITIVITY ('ALIBRATION FOR ATASSAYSI'LM

${ }^{241} \mathrm{Am}$ Content in ${ }^{239} \mathrm{Pu}$ Standards:

$$
\begin{array}{lll}
{ }^{241} \mathrm{Am} & 59.537 \mathrm{keV} & \gamma \text {-ray } \\
& \mathrm{L}_{\alpha} \text { X-ray } & \\
& \mathrm{L}_{\beta} \text { X-ray } \\
& \mathrm{L}_{\gamma} \text { X-ray } \\
& \\
{ }^{239} \mathrm{Pu}^{\mathrm{a}} & \mathrm{L}_{\alpha} \text { X-ray } \\
& \mathrm{L}_{\beta} \text { X-ray } \\
& \mathrm{L}_{\gamma} \text { X-ray }
\end{array}
$$

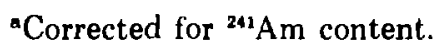

$0.0161 \frac{\mathrm{pCi} \mathrm{Am}}{\mathrm{pCi} \mathrm{Pu}}$
Sensitivity $(\mathrm{c} / \mathrm{s}) /(\mathrm{pCi} / \mathrm{g})$

$0.0283 \pm 1.6 \%$
$0.00137 \pm 2.5 \%$
$0.00542 \pm 1.3 \%$
$0.00179 \pm 1.2 \%$
$0.000315 \pm 4.6 \%$
$0.000970 \pm 3.7 \%$
$0.000273 \pm 2.8 \%$


TABLE XXXV

\begin{tabular}{|c|c|c|}
\hline $\begin{array}{l}\text { Amount-of } \\
{ }^{241} \mathrm{Am} \text { Added to } \\
\text { Sample Container } \\
\text { (pCi) }\end{array}$ & $\begin{array}{c}\text { Average Net } \\
\text { Counts for } \\
16000 \mathrm{~s} \\
\text { Count Time }\end{array}$ & $\begin{array}{c}\text { Average } \\
\text { Net } \\
\text { c/s/pCi }\end{array}$ \\
\hline 1.02 & $37.0(33.5)^{\mathrm{a}}$ & $36.3(32.8)$ \\
\hline 5.10 & $139.0(7.02)$ & $27.3(1.38)$ \\
\hline 10.2 & $258.0(21.5)$ & $25.3(2.11)$ \\
\hline 102 & $2513.0(220)$ & $24.6(2.16)$ \\
\hline 1020 & $28360.0(4606)$ & $27.8(4.52)$ \\
\hline 15300 & $427237.0(5384)$ & $27.9(0.35)$ \\
\hline
\end{tabular}

"Average of three replicate determinations with mean standard deviation in parenthesis.

TABLE XXXVI

\section{IG DETECTOR RESPONSE TO VARYING AMOUNTS OF WEAPONS GRADE PLUTONIUM}

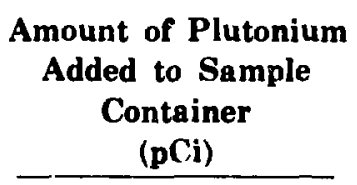

4.5

9.0

19.5

22.5

45

90

1500

13320

\begin{tabular}{ccc}
$\begin{array}{c}\text { Average Net } \\
\text { Counts for } \\
16 \text { 000 s } \\
\text { Count Time }\end{array}$ & $\begin{array}{c}\text { Average } \\
\text { Net } \\
\text { c/s/pCi }\end{array}$ \\
\cline { 2 - 3 } & & \\
$102(68.8)^{a}$ & & $22.7(15.3)$ \\
$168(95)$ & & $18.7(10.6)$ \\
$91(66.6)$ & & $4.67(3.42)$ \\
$112(71)$ & & $4.98(3.16)$ \\
$265(69.9)$ & $5.89(1.55)$ \\
$392(93)$ & $4.36(1.03)$ \\
$4103(239)$ & $2.74(0.16)$ \\
$45621(2972)$ & $3.43(0.22)$
\end{tabular}

Average Net Counts for $16000 \mathrm{~s}$

\footnotetext{
"Average of three replicate determinations with mean standard deviation in parentheses.
} 


\section{ACKNOWLEI)GMENT'S}

This report was compiled by the staff of the Environmental Surveillance Group (H-8) of 1.ASI,'s Health Division. Principal contributors included A. J. Ahlquist. D. A. Dahl, R. W. Ferenhaugh. F. ('. Fernald, E. S. Gladney. T. C. Ciunderson, W. R. Hansen, W. D. Purtymun, K. H. Rea, A. K. Stoker. (. R. Steen, A. D. Talley, and I. .J. Walker. Much of the sampling and dat a collection was done by G. H. Brooks, Jr., C' Conley, F. R. Craven, R. R. Critchfield, G. R. Fox, M. N. Maes, J. Rice, R. Romero, d. (i. Salazar, H. K. Torres, D), M. Van Etten, and C. L. Wardlow. Analytical chemistry was performed by (C. F. Burns, W. M. Eherhardt, W. E. Goode, P. I. .Johnson. I). Knab. (;. M. Martinez. I. Ortiz. J. W. Owens. R. J. Peters, D. R. Perrin, and W. H. Schweitzer. Typing was done hy V. Halloran and M. L. Keigher. Word processing and assembly of this report was done by $\mathrm{K}$. Derouin.

Special thanks to LASL's Environmental Studies (iroup (LS-f) for descriptions of their environmental research. Principal contributors included T. S. Foxx, T. F. Hakonson, C. L. Meci, J. Crowell, B. .J. I rennon, J. W. Jyhan, I. D. Potter, J. (i. Steger, (i. I). 'Tierney, (i. Trujillo, E. M. Wewerka. and (i. C. White. Technical support was provided by K. V. Bostick, E. M. Karlen, and J. L. Martinez. 


\section{REFERENCES}

1. W. D. Purtymun, J. R. Buchholz, and T. E. Hakonson, "Chemical Quality of Effluents and Their Influence on Water Quality in a Shallow Aquifer," J. of Environmental Quality 6, No. 1 (Jan-Mar 1977).

2. W D. Purtymun and S. Johansen, "General Geohydrology of the Pajarito Plateau," N.M. Gel. Soc. Guidebook, 25th Field Conference, Ghost Ranch, New Mexico (1974).

3. "Final Environmental Impact Statement: Los Alamos Scientific Laboratory Site, Los Alamos, New Mexico," U.S. Department of Energy, DOE/EIS-0018, Washington, D.C. (December 1979).

4. National Council on Radiation Protection and Measurements, "Natural Background Radiation in the United States," NCRP Report No. 45 (November 1975).

5. Environmental Surveillance Group, "Environmental Surveillance at Los Alamos during 1977," Los Alamos Scientific Laboratory report LA-726:3-MS (Ápril 1978).

6. Environmental Protection Agency, "National Interim Primary Drinking Water Regulations," EPA-570/9-76-003, U.S. Government Printing Office, Washington, D.C. (1976).

7. W. D. Purtymun, R. J. Peters, and A. K. Stoker, "Radioactivity in Soil and Sediments in and Adjacent to the Los Alamos Area, 1974-1977," Los Alamos Scientific Laboratory report LA-8234MS (1980).

8. W. R. Kennedy and W. D. Purtymun, "Plutonium and Strontium in Soil near Technical Area 21, Los Alamos Scientific Laboratory, New Mexico," Los Alamos Scientific Laboratory report LA.4563 (1971).

9. Environmental Surveillance Group, "Environmental Surveillance at Los Alamos During 1978," Los Alamos Scientific Laboratory report LA-7800-ENV (April 1979).
10. "Food Consumption, Prices, and Expenditu:es," AER-138, U.S. Department of Agriculture, Washington, D.C. (December 1976).

11. T. E. Hakonson, Los Alamos Scientific Laboratory, personal communication, February 8,1980 .

12. R. E. Grout, The Hive and the Honey Bee (Dandt and Sons, Hamilton, Illinois, 1970).

13. Environmental Protection Agency, "Compilation of Air Pollutant Emission Factors, " Parts A and B, Supplements 1-7, Third Edition, Research Triangle Park, North Carolina (1977).

14. Mason and Hanger-Silas Mason Co., Inc., "Disposal of Waste or Excess High Explosives," Quarterly Progress Reports from January 1971 through March 1976.

15. D. T. Oakley, "Natural Radiation Exposure in the United States," US EPA report ORP/SID 72. 1 (June 1972).

16. "Radiological Quality of the Environment in the United States, 1977," US EPA report EPA52U/1-77-009 (Sept. 1977).

17. W. D. Purtymun, "Plutonium in Stream Channel Alluvium in the Los Alamos Area, New Mexico," Los Alamos Scientific Laboratory report LA-4561 (1971).

18. T. E. Hakonson and K. V. Bostick, "Cesium-137 and Plutonium in Liquid Waste Discharge Areas at Los Alamos," in Radioecology and Energy Resources (Dowden, Hutchinson, \& Ross, Inc., Stroudsburg, Pennsylvania); F. R. Miera, Jr., and R. J. Peters, "The Distribution of Plutonium and Cesium of Alluvial Soils in the Los Alamos Environs," in Radioecology and Energy Resources (Dowden, Hutchinson \& Ross, Inc., Stroudsburg, Pennsylvania, 1976).

19. W. D. Purtymun, "Storm Runoff and Transport of Radionuclides in DP Canyon, Los Alamos County, New Mexico," Los Alamos Scientific Laboratory report LA-5744 (1974). 
20. T. E. Hakonson, J. W. Nyhan, and W. D. Purtymun, "Accumulation and Transport of Soil Plutonium in Liquid Waste Discharge Areas at Los Alamos," Proc. Transuranium Nuclides in the Environment, International Atomic Energy Agency, IAFA-SM-199/99 (Vienna, Austria, 19761.

21. H. (.. Paxton, "Safety and Analysis of the Los Alamos Critical Experiments Facility," Los Alamos Scientific Laboratory report LA-6206, Vol. Il (October 1975).

22. J. M. Voltin and J. M. Graf (H-1), private communication (February 1979).

23. National Council on Radiation Protection and Measurements, "Review of the Current State of Radiation Protection Philosophy, NCRP report No. 4:3, p. 2-33 (1975).

24. International Commission on Radiological Protection, "Recommendations of the International Commission on Radiological Protection," (adopted January 17, 1977), Annals of the IC.IRP, Vol. 1, No. 3, 1977, Pergamon Press, Elm. sford, New York.

25. Cancer Research and Treatment Center, University of New Mexico Epidemiology Section, Albuquerque, NM.

26. Environmental Protection Agency, "National Emission Standards for Identifying, Assessing and Regulating Airborne Substances Posing a Risk of Cancer," Federal Register 44, No. 197, Oct. 10, 1979, p. 58643.

27. D. B. Yeates, A. S. Goldin, and D. W. Moeller, "Natural Radiation in the Urban Environments," Nuclear Safety 13, No. 4, July-Aug., 1972 , p. 2754.

28. A. W. Klement, Jr., et al., "Estimates of Ionizing Radiation Doses in the United States 19602000," US EPA report ORP/CSO 72-1, August 1972.
29. JASL Fngineering Department of Quality Assurance, "LASL Quality Assurance Manual for Engineering and Construction," Los Alamos Scientific Laboratory report LA-5220-M (May 1974).

30. C. R. Steen, "Pajarito Plateau Archaeological Survey and Excavations," Los Alamos Scientific Laboratory report LASL-77-4 (May 1977).

31. The Atom, "A Kiva is Excavated-This Time with Metal Tools," published by Los Alamos Scientific Laboratory, The Atom If, 8, pp. 20-23 (October 1979).

32. The Atom, "Indian Pots Sealed in 15th Century," published by Los Alamos Scientific Laboratory, The Atom 16, 6, pp. 16-18 (July/August 1979).

33. T. S. Foxx and L. D. Potter, "Fire Ecology at Bandelier National Monument," Contract No. PX 7029-6-0769 and No. PX7029-7-0692, Final Report, National Park Service, Santa Fe, NM (1978).

34. L. D. Potter and T. S. Foxx, "Success of Seeding Native Grass After a Holocaustic Fire," Final Report (Part II). Eisenhower Consortium, U.S. Forest Service, Rocky Mountain Forest and Range Experiment Station, Fort Collins, Colo. (1979).

35. The Atom, publication of Los Alamos Scientific Laboratory (August 1977).

36. T. S. Foxx and G. D. Tierney, "Status of the Flora of the National Environmental Research Park," Los Alamos Scientific Laboratory report (in press).

37. W. D. Purtymun and W. H. Adams, "Geohydrology of Bandelier National Monument" (in press).

38. W. D. Purtymun, "Geology of the Jemez Plateau West of the Valles Caldera, "Los Alamos Scientific Laboratory report LA-5124-MS (February 1973). 
39. W. D. Purtymun, F. (i. West, and R. A. Pettitt, "(iechlong of (ieothermal Test Hole GT-2, Fenton Hill Site. July 1974," Los Alamos Scientific laburatrry report LA-5780-MS (November 1974 .

41). W. I). Pursumun, W. H. Adams, and J. W. Owens. Water Quality in Vicinity of Fenton Hill Site, 1974," Los Alamos Scientific Laboratory report LA-6093 (December 1975).

41. W. B. I'urtymun, W. H. Adams, A. K. Stoker, and F. ( 3 . West, "Water Quality in Vicinity of Fenton Hill Site, 2975," Los Alamos Scientific laboratory report LA-6511-MS (September lisitis.

12. W. I). Purtymun, W. H. Adams, and A. K. Stoker. "Water Quality in the Vicinity of Fenton Hill Site, 1976," Los Alamos Scientific laburatory report LA-7307-MS (June 1978).

43. W. D. Purtymun, A. K. Stoker, W. H. Adams, and J. $\mathbb{W}$. Owens, "Water Quality in Vicinity of the Fenton Hill Site, 1977," Los Alamos Scien. tific Laboratory report LA-7468-PR (September 19781.

4.4. W. 1), Purtymun, R. W. Ferenbaugh, A. K. Stciker. W. H. Adams, and J. W. Owens, "Water Quality in the Vicinity of Fentun Hill Site, $1978 . "$ Les Alamos scientific Laboratory report L.A-8.217-1'R (in press).

4i. T. E. Hakonson, J. W. Nyhan, and W. D. Purtymun. "Accumulation and Transport of Soil Plutonium in Liquid Waste Disposal Areas at I cos Alamos," in Transuranium Nuclides in the Enviromment, IAEA/ERDA Symp., IAEA-SM199/99; Vienna, pp. 175-189 (1976).
46. (. A. Little and F, W. Whicker, "Plutonium in a (irassland Ecosystem," W. C. Hanson (Ed.) in Transuranic Elements in the Environment, PID-2280) (1979).

47. D. (i. Siprugel and G. E. Bartlet, "Erosional Removal of Fallout Plutonium from a Large Midwestern Watershed," J. Environ. Qual. 7, Vo. 2. pp. 175)-177 (1978).

48. R. N. Muller, D. G. Sprugel, and B. Kohn, "Erosional Transport and Deposition of Plutonium and Cesium in Two Small Midwestern Watersheds," J. Environ. Qual. 7, No. 2. pp. 171-174 (1978).

49. (i. A. Sehmel, "Transuranic and Tracer Simulant Resuspension," Pacific Northwest Laboratories, BNWL-SA-6236 (1978).

50. L. R. Anspaugh, P. L. Phelps, N. C. Kennedy, J. H. Shinn, and J. M. Reichman, "Experimental Studies on the Resuspension of Plutonium from the Aged Sources at the Nevada Test Site," in Atmosphere-Surface Exchange of Particulate and (raseous Pollutants. Report CONF-74092, pp. T27-7.43 (1974).

j1. S. Siegel, "Nonparametric Statistics for the Behaviural Sciences," McGraw-Hill, New York (1956).

52. L. L. Eberhardt, "Sampling for Radionuclides and Other Trace-Substances," in Radioecology and Energy Resources, Dowden, Hutchinson, and Ross, Stroudsberg, PA, C. E. Cushing, Jr. (Ed.) (1976). 


\section{APPENDIX A}

\section{STANDARDS FOR ENVIRONMENTAL CONTAMINANTS}

The concentrations of radiosactive and chemical contaminants in air and water samples collected throughust the environment are compared with pertiment standards contained in the regulations of several federal and state agencies in order to verify the Iaburatory's compliance with these standards. Hecause many l)(ofirders, manuals, and directives are still being promulgated and were not considered final at the time this report was being written, numerous reterences have been made to Energy Research and Development Administration (ERDA) Manual (hapters which continue to serve as guidelines until superseded by the final DOE orders and manuals. I.ASI operations pertaining to envirunmental quality control are conducted in accordance with the directives and procedures contained in FRI'A's Health and Safety Manual, Chapters (15) $10,0511,0513,0524$, and 0550 .

In the case of radioactive materials in the environment, the guides contained in Manual Chapter 0524 are used as a basis for evaluation. However, the FHI)A standard for uranium in water $(1500$ and 60 $\mathrm{m}_{\mathrm{n}} / \mathrm{l}$ for controlled and uncontrolled areas, respectively) does not consider chemical toxicity. Therefore, for the purposes of this report, the more restrictive standards ${ }^{+1}$ of the International Commission on Radiological Protection (ICRP) for uranium in water ( $60 \mathrm{mg} / \ell$ for an occupational 40 -h week) are use't as a point of comparison. For atmospheric uranium, the ERDA and ICRP standards are in agreement. The standards are listed in Table A-I in the form of a Radioactivity Concentration Guide ( $(')$. A CG is the concentration of radioactivity in air breathed continuously or water constituting all that ingested during a year that is det armined to result in whole body or organ doses equal to the Radiation Protection Standards (RPSs, listed in Table A-II) for internal and external exposures. Obviously, there are uncertainties in relating CGs to RPSs. Uncontrolled Area CGs correspond to RPSs for the general public, whereas Controlled Area CGs correspond to Rl'sis for workers. Thus, common practice and stated FiRI)A policy in Manual (hapter 0:524 are that operations shall be "conducted in a manner to assure that radiation ex. posure to individuals and population groups is limited to the lowest levels technically and economically practicable.

Because some radioisotopes remain in the body and cause exposure long after intake has occurred, the RPSis require consideration of the dose commit. ment caused by inhalation, ingestion, or absorption of such isotopes. For purposes of this report, 50-yr dose commitments were calculated where appropriate using dose factors from Ref. A-2.

For chemical pollutants in water supply, the controlling standards are those promulgated by either the Environmental Protection Agency (EPA) or the New Mexico Environmental Improvement Division (NMEII), see Table A-III). EPA's ınaximum contaminant level (MCL) is the maximum permissible level of a contaminant in water which is delivered to the free flowing outlet of the ultimate user of a public water system. ${ }^{\text {A2 }}$

Radioactivity in public water supply is governed by EPA regulations contained in 40CFR141. These regulations provide that combined ${ }^{226} \mathrm{Ra}$ and ${ }^{228} \mathrm{Ra}$ shall not exceed $5 \mathrm{pCi} / \ell$ and gross alphe activity (including ${ }^{20} \mathrm{Ra}$, but excluding radon and uranium) shall not exceed $15 \mathrm{pCi} / \boldsymbol{l}$. A screening level of 5 $\mathrm{pCi} / \boldsymbol{l}$ is established as part of the monitoring requirements to determine whether specific radium analyses must be performed.

For man-made radionuclides the EPA drinking water regulations specify that concentration be limited to levels that would result in doses of 4 $\mathrm{mrem} / \mathrm{yr}$ calculated according to a specified procedure. The EPA calculated value for tritium $\left({ }^{3} \mathrm{H}\right)$ is $20 \times 10^{-6} \mu \mathrm{Ci} / \mathrm{m} \ell$ and for cesium $\left({ }^{137} \mathrm{Cs}\right)$ is $200 \times 10^{-9} \mu \mathrm{Ci} / \mathrm{m} \ell^{{ }^{A a}}$ The calculated concentration using bone as the critical organ and the EPA 
prescribed methods ${ }^{\mathrm{A} 2}$ for ${ }^{230} \mathrm{Pu}$ or ${ }^{239} \mathrm{Pu}$ is $7.5 \times 10^{\circ}$ $\mu \mathrm{Ci} / \mathrm{m} \ell$.

\section{REFERENCES}

Al. International Commission on Radiological Protection (ICRP), "Recommendations of the International Commission on Radiological Protection," ICRP Publ. 6, Pergamon Press, New York (1964).
A2. ERDA, "A Guide for Environmental Radiological Surveillance at ERDA Installations," US ERDA, Div, of Safety, Standards and Compliance, publication ERDA-77-24 (March 1977).

A3. Environmental Protection Agency, "National Interim Primary Drinking Water Regulations," EPA-570/9-76-003, US Govt Printing Office, Washington, DC (1976). 
TABLE A-1

ERDA RADIOACTIVITY CONCENTRATION GUIDES (CGs)

\begin{tabular}{|c|c|c|c|}
\hline \multirow[b]{2}{*}{ Nuclide } & \multirow{2}{*}{$\frac{\text { CG for Air }}{(\mu \mathrm{Ci} / \mathrm{m} \ell)}$} & \multicolumn{2}{|c|}{ CG for Water } \\
\hline & & $(\mu \mathrm{Cl} / \mathrm{m} \ell)$ & $(\mathrm{nCi} / \mathrm{l})$ \\
\hline 'H & $2 \times 10^{-1}$ & $3 \times 10^{-2}$ & 3000 \\
\hline 'He' & $\ldots$ & $2 \times 10^{-1}$ & 2000 \\
\hline${ }^{11}\left(. .{ }^{10 N},{ }^{10}()\right.$ & $3 \times 10^{-\bullet}$ & $\ldots$ & $\ldots$ \\
\hline "Ar & $4 \times 10^{-1}$ & ... & $\ldots$ \\
\hline$\infty$ otr & $3 \times 10^{-10}$ & $3 \times 10^{-0}$ & 3 \\
\hline${ }^{\infty} \leqslant r^{0}$ & $3 \times 10^{-11}$ & $3 \times 10^{-1}$ & 0.3 \\
\hline 1310 & $1 \times 10^{-10}$ & $3 \times 10^{-1}$ & 0.3 \\
\hline $\operatorname{lon}(\mathrm{s}$ & $5 \times 10^{-10}$ & $2 \times 10^{-1}$ & 20 \\
\hline $2 \omega M_{11}$ & $7 \times 10^{-14}$ & $5 \times 10^{-6}$ & 5 \\
\hline $201 p^{0}$ & $6 \times 10^{-14}$ & $5 \times 10^{-\bullet}$ & 5 \\
\hline n'Am & $\begin{array}{l}2 \times 10^{-18} \\
\left(\mathrm{pg} / \mathrm{m}^{\mathrm{o}}\right)^{\mathrm{c}}\end{array}$ & $4 \times 10^{-0}$ & $\left(\mathrm{mg}^{4} /\right)^{4}$ \\
\hline $\operatorname{l}^{\prime}$ natura|c & $9 \times 10^{4}$ & $2 \times 10^{-1}$ & $\begin{array}{l}60 \\
1.8 \text { IIC }\end{array}$ \\
\hline
\end{tabular}

\begin{tabular}{|c|c|c|c|}
\hline \multicolumn{4}{|c|}{ Concentration Guide for Controlled Areas ${ }^{a . b}$} \\
\hline \multirow[b]{2}{*}{ Nuclide } & \multirow{2}{*}{$\frac{\text { CG for Air }}{(\mu \mathrm{Ci} / \mathrm{m \ell})}$} & \multicolumn{2}{|c|}{ CG for Water } \\
\hline & & $(\mu \mathrm{Ci} / \mathrm{m} \ell)$ & $(\mathrm{nCi} / \mathrm{l})$ \\
\hline${ }^{\circ} \mathrm{H}$ & $5 \times 10^{-\bullet}$ & $1 \times 10^{-1}$ & $1 \times 10^{4}$ \\
\hline 'He & $\ldots$ & $5 \times 10^{-2}$ & $5 \times 10^{4}$ \\
\hline 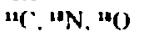 & $1 \times 10^{-\infty}$ & ... & $\ldots$ \\
\hline "AT & $2 \times 10^{-0}$ & $\ldots$ & $\ldots$ \\
\hline $\operatorname{mir}$ & $3 \times 10^{-}$ & $3 \times 10^{-4}$ & 300 \\
\hline asr & $1 \times 10^{-0}$ & $1 \times 10^{-1}$ & 10 \\
\hline 1110 & $4 \times 10^{-0}$ & $3 \times 10^{-1}$ & 30 \\
\hline $\operatorname{ser}(' s$ & $1 \times 10^{-\bullet}$ & $4 \times 10^{-4}$ & 400 \\
\hline mplu & $2 \times 10^{-12}$ & $1 \times 10^{-4}$ & 100 \\
\hline$m p u^{a}$ & $2 \times 10^{-12}$ & $1 \times 10^{-1}$ & 100) \\
\hline "Am & $6 \times 10^{-12}$ & $1 \times 10^{-4}$ & 100 \\
\hline & $\left(\mathrm{pg} / \mathrm{m}^{\mathrm{l}}\right)^{\mathrm{c}}$ & & $(\mathrm{mg} / \ell)$ \\
\hline (1. naturale & $2.1 \times 10^{4}$ & $5 \times 10^{-4}$ & $\begin{array}{l}1500) \\
60) \text { IICRPe, }\end{array}$ \\
\hline
\end{tabular}

-This table contains the most restictive CGs for nuclides of major interest gt I.ASI. (Filk])A Manual Chap. 0524, Annex A).

"CGs apply to rs dionuclide concentrations in excess of that occurring nat urally or due to falloul.

-One curie of natural uranium is equivalent to $3000 \mathrm{~kg}$ of natural uranium. Hence, uranium mas. ses may be converted to the ERDA "uranium special curie" by using the factor $\left.3.3 \times 10^{-12} \mu{ }^{-1} 1 / 1\right) k$.

-Or the possible alphs and beta emitting radionuclides relessed at LASI. mPu and "uI. resper. tively, have the most restrictive CGs. The CGs for these species are used for the gross alpha and moss beta $\mathrm{CG}$, respectively.

-For purpnses of this report, concentrations of total uranium in water art comprirr.ci in the I(' $\left.R\right|^{\prime}$ recumnended values which consider chemical toxicity. 
TABLE A-I]

\section{GRDA RADIATION PROTECTION STANDARDS FOR} EXTERNAL AND INTERNAL EXPOSL'RES

\begin{tabular}{|c|c|c|}
\hline \multicolumn{3}{|c|}{$\begin{array}{l}\text { Individunls and Population Groups } \\
\text { in Uncontrolled Areas }\end{array}$} \\
\hline & \multicolumn{2}{|c|}{$\begin{array}{l}\text { Annual Dose Equivalent or } \\
\text { Dose Commitment (rem)" }\end{array}$} \\
\hline $\begin{array}{l}\text { Type of } \\
\text { Exposure }\end{array}$ & $\begin{array}{l}\text { Based on Dose } \\
\text { to Individuals } \\
\text { at Points of } \\
\text { Maximum } \\
\text { Probabie } \\
\text { Exposure }\end{array}$ & $\begin{array}{l}\text { Based on an } \\
\text { Averase Dose } \\
\text { to a Suitable } \\
\text { Sample of } \\
\text { the Exposed } \\
\text { Population' }\end{array}$ \\
\hline $\begin{array}{l}\text { Whule tionds. gonads, or } \\
\text { lune narrow }\end{array}$ & 0.5 & 0.17 \\
\hline Other urgans & 1.5 & 0.5 \\
\hline
\end{tabular}

Individuats in Controlled A reas

\begin{tabular}{|c|c|c|}
\hline Type of Exposure & Exposure Perjod & $\begin{array}{l}\text { Dosc Fquivalent } \\
\text { [Dose or Dose } \\
\text { Commitmen!" (rem)] }\end{array}$ \\
\hline $\begin{array}{l}\text { Whole hody. head and trunk, gonads, lens ot } \\
\text { the eve. red bone marrok, active bliond } \\
\text { forming organs. }\end{array}$ & $\begin{array}{c}\text { Year } \\
\text { Calendar Quarter }\end{array}$ & $\begin{array}{l}5 \\
: 1\end{array}$ \\
\hline $\begin{array}{l}\text { (Inlinited areas of the skin (except hands } \\
\text { and forearms). Other organs, tissues, and } \\
\text { organ sustems (except bonel. }\end{array}$ & $\begin{array}{c}\text { Year } \\
\text { Calendar Quarter }\end{array}$ & $\begin{array}{l}1: i \\
\therefore i\end{array}$ \\
\hline Bune & $\begin{array}{c}\text { Year } \\
\text { Calendar Quarter }\end{array}$ & $\begin{array}{l}101 \\
10\end{array}$ \\
\hline Furearms ${ }^{\circ}$ & $\begin{array}{c}\text { Year } \\
\text { Calendar Jear }\end{array}$ & :31 \\
\hline Hands: and leet & $\begin{array}{c}\text { Year } \\
\text { Calendar Quarter }\end{array}$ & ii \\
\hline
\end{tabular}

- To meet the above dose commitment standards, operations must be conducted in such a manner that it wnuld be unlikely that an individual would assimilate in a critical orkan. by inhalation. in. gestion, or absorption, a quantity of a radionuclide(s) that would commit the individual to an organ dose which exceeds the limits specified in the above table.

-A beta exposure below a maximur energy of $700 \mathrm{keV}$ will not penetrate the lens of the eve: therefore, the applicable limit for ihese energies would be that for the skin (15 rem/vear).

In special cases with the approval of the Director. Division of Safety. Standards, and Compliance, a worker may exceed $5 \mathrm{rem} / \mathrm{year}$ provided his/her average exposure per year since age 18 will not exceed 5 rem per year.

-All reasonable effort shall be made to keep exposure of forearms and hands tu the general limit for the skin. 
TABLE A-III

\section{MAXIMUM CONTAMINANT LEVEL (MCL) IN WATER SUPPLY FOR INORGANIC CHEMICALS AND RADIOCHEMICAIS*}

\begin{tabular}{|c|c|}
\hline $\begin{array}{l}\text { Inorganic } \\
\text { Chemical } \\
\text { Contaminant }\end{array}$ & $\begin{array}{l}\text { MCL } \\
(\mathbf{m g} / \mathbf{l})\end{array}$ \\
\hline 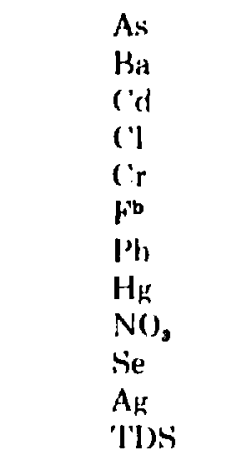 & $\begin{array}{c}0.05 \\
1.0 \\
0.010 \\
250 \\
0.05 \\
2.0 \\
0.05 \\
0.002 \\
45 \\
0.01 \\
0.05 \\
1(\text { (К) }\end{array}$ \\
\hline $\begin{array}{l}\text { Adiochemical } \\
\text { Contaminant }\end{array}$ & $\underset{(\mu \mathrm{Ci} / \mathbf{m} \ell)}{\mathrm{MCL}}$ \\
\hline $181 C_{s}$ & $200 \times 10^{-n}$ \\
\hline $\begin{array}{l}\text { Gross alpha } \\
{ }^{2 H} \\
{ }^{220} \mid{ }^{\prime} \mathrm{u} \\
\left.{ }^{200}\right]_{\mathrm{\prime}}\end{array}$ & $\begin{array}{r}5 \times 10^{-0} \\
20 \times 10^{-0} \\
7.5 \times 10^{-0} \\
7.5 \times 10^{-0}\end{array}$ \\
\hline
\end{tabular}

-USEPA National Interim Primary Drinking Water Regulations (EPA-570/9-76-0)3), EPA, Office of Water Supply (1976) and NMEID Water Supply Regulations (Regulations Governing Water Supply, N.M. Environmental Improvement Agency, Santa Fe, N.M., Dec. 9, 1977).

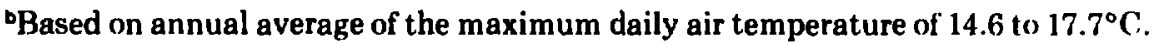




\section{APPENDIX B}

\section{SAMPLING PROCEDURES AND STATISTICAL TREATMENT OF DATA}

\section{Thermoluminescent Dosimeters}

Lithium lluoride chips, $6.4 \mathrm{~mm}$ square by $0.9 \mathrm{~mm}$ thick, are used in both the environmental and Los Alamos Meson Physics Facility (LAMPF) networks. The chips are annealed at $400^{\circ} \mathrm{C}$ for $1 \mathrm{~h}$ and then cooled rapidly to room temperature. In order for the annealing conditions to be repeatable, the chips are put into rectangular borosilicate glass vials that hold $48 \mathrm{l}$,iF chips each. These vials are slipped into rectangular holes formed by stacking machined stainless steel blocks inside an oven maintained at $4000^{\circ} \mathrm{C}$. After $1 \mathrm{~h}$ the vials are removed from the oven and placed between massive copper blocks at room temperature.

The TLD reader is set for $15 \mathrm{~s}, 140^{\circ} \mathrm{C}$ preheat and $15 \mathrm{~s}, 240^{\circ} \mathrm{C}$ int egration cycles. Incandescent lighting is used exclusively during all phases of annealing, dosimeter preparation, and readout to prevent ultraviolet-induced spirious TL (thermoluminescencel. Four thips are placed in a molded nylon acorn nut, sıze $3 / 8-16$, then closed with a $3 / 8-16 \times 1 / 4$ in nylon set screw. This assembly constitutes one dosimeter.

For each annealed batch, two calibration sets are exposed. One set is read at the beginning of the dosimetry cycle along with field and calibration sets from the previous cycle. The second is read at the end of the previous cycle. The second is read at the end of the cycle to detect possible sensitivity drift. Each calibration set consists of 20 dosimeters irradiated at the following levels: 3 at $0 \mathrm{mR}$ are stored as laboratory controls, 3 at $0 \mathrm{mR}$ accompany the set to the irradiation facility and serve as calibration controls, 3 at $0 \mathrm{mR}$ accompany the field set as transit controls, 4 at $10 \mathrm{mR}, 4$ at $20 \mathrm{mR}, 1$ each at 40,80 , and $160 \mathrm{mR}$. A factor of 1 rem (tissue) $=$ $1.061 \mathrm{R}$ is used in evaluating the dosimeter data. This factor is the reciprocal of the product of the roentgen to rad conversion factor of 0.957 for muscle for ${ }^{80} \mathrm{Co}$ (the isotope used for TLD calibrations) and the factor 0.985 , which corrects for attenuation of the primary radiation beam at electronic equilibrium thickness. A rad-to-rem conversion factor of 1.0 for gamma rays is used as recommended by the International Commission on Radiation Protection." A method of weighted least squares linear regression is used to determine the relationship between TLD reader response and dose (weighting factor is the reciprocal of the variance).$^{\mathrm{H}}$

The TLD chips used are all from the same production batch and were selected by the manufacturer so that the measured standard deviation in $\mathrm{TL}$ sensitivity is 2.0 to $4.0 \%$ of the mean at $10 \mathrm{R}$ exposure. At the end of each field cycle, whether calendar quarter or LAMPF operation cycle, the dose at each network location is calculated along with the upper and lower limits at the $95 \%$ confidence level. ${ }^{H 3}$ At the end of the calendar year, individual field cycle doses are summed for each location. Uncertainty is calculated as the square root of the sum of squares of the individual standard deviation by assuming that the $95 \%$ confidence interval closely approximates the same interval as \pm 2 standard deviations. The dose at the LASL boundary north of LAMPF is calculated differently. Here 12 locations are in close proximity and the dose at the end of each cycle is calculated as the mean of all 12 locations. Because there is a dosimeter containing four chipr $\approx$ : each location, this is actually a grand mean (or mean of means) and the standard deviation is therefore smaller by a factor of almost a third $(1 / \sqrt{12})$ than that of any of the individual dosimeters.

In order to calculate the magnitude of the component of the total dose caused by LAMPF operations, three locations along the south boundary of LASL are used for background values. These locations are distant from and unaffected by LAMPF or any other laboratory source of radiation. They are close 
encugh in olevation to the I.A.MPF site to experience similar climatir conditions such as rain and smowfall.

The rationale for this calculation is based on the ration of the dose recorded by the unshielded desimeter 1 that for the lead and lucite-shielded dusimelar. This ratio should be the same for desimeters af both the north and south lisuridaries because the resmir garnma component is quite slable and because the terrestrial conditions are neatly the same. Any decrease in the ratio at the north boundary is assumed to be caused by I.A.MPF uperations. The actual inethod of ralculation lollows. Let $\%$ be the dose component from IAMPF, 11 and $v$ be the unshielded and shielded dose means, respectively, at the north hesundary, $u^{\prime}$ and $v^{\prime}$ be the ir counterparts at the south boundary, and $s_{u}$, $S_{2}, S_{u}$ '. $S_{v}$ ' he the standard deviation of these means. Then

$z=u-(v \mid u)|r|$

The uncertainty asserciated with this value can be relermined from the relationshipen

$$
\begin{aligned}
S_{z}^{2} & =\left(\partial_{z} /\left(\omega_{u}\right)^{2} S_{u}^{2}+(i)_{z} /\left(\partial_{v}\right)^{2} S_{v}^{2}\right. \\
& +(i)_{z} /\left(\partial_{u^{\prime}}\right)^{2}+\left(\partial_{z} /\left(\partial_{v} \cdot\right)^{2} S_{v}^{2} .\right.
\end{aligned}
$$

\section{Air Sampling}

Samples are coinded monthly at 25 continuously (iperating stations during 1979. Positive displacement air pumps with flow rates of approximately:3 $\ell / s$ are used. Atmospheric aerosols are collected on $79 \mathrm{~mm}$ diam polytityrene filters. Part of the total air fliw $(2.4-3.1 \mathrm{~m} / / \mathrm{s})$ is passed through a cartridge containing silica gel to adsorb atmospheric water vapor for tritium analyses. Air flow rates through hoth sampling cartridges are measured with variable-area llow meters, and sampling times recorded.

(iross alpha and gross beta activities on the monthly air filters are measured with gas-flow proportional counter on collection day and again 7 (1) 10 days after collection. The first count is used to screen sainples for inordinate activity levels. The second count (made after absorbed, naturallysccurring, radon-thoron daughters had reached equilibrium with the long-lived parents) provides a record of keng lived atmonpheric radioactivity.

At one lesation (Nos)-Eotol atmospheric radinactivits samples are collected daily (Monday thresugh Friclayl. Almospheric particulate matter on wach daily filter in connted for gross alpha and gross beta activities on collection day and again 7 to 10 days after collection. The first measurement provides an carly indication of any major change in atmospherir radionctivity. The second measuremonts are used to observe temporal variations in long-lived atmospheric radiractivity.

After beeing measured for gross alpha and gross heta activities, the monthly filters for each station are cut in halt. The first group of filter halves is then combined and discolved to produce quarterly compesite samplen for each station. The second group of filter halves is sived for uranium analysis.

Plutsiatum is separated from the solution by anion exchange. For 11 selected stations, americium is separated by cation exchange from the eluent solutions from the plutonium separation process. The purified plutrinium and americium samples are separately electrodepessited and measured for alphaparticle emission with a solid-state alpha detection system. Alpha-particle energy groups associated with the decay of ${ }^{239} \mathrm{P} u$. ${ }^{239} \mathrm{P} u$. and ${ }^{241} \mathrm{Am}$ are intekrated, and the concent ration of each radionuclide in its respective air sample calculated. This technique does not differentiate between ${ }^{238} \mathrm{P} u$ and ${ }^{24}$ Pu. Iranium analyses by neutron activation analysis tsee Appendix (') are dome on the second group of filter halves.

Silica gel cartridges form the 25 air sampling stations are analyzed monthly for tritiated water. The cartridges contain a small amount of blue "indicating" gel at each end to indicate a desiccant over-sat uration. During cold months of low absolute humidity, sampling flow rates are increased to ensure collection of enough waier vapor for analysis. Water is distilled from each silica gel sample, yielding a mont hly average atmospheric water vapor san yle. An aliquot of the distillate is then analyzed for a tium by liquid scintillation counting.

Measurements of the air particulate samples require that chemicai ir instrumental backgrounds be subtracted to obtain net values. Thus, nế values lower than the minimum detection limit (MDL) of 
the system were sometimes obtained (see Table C. IV). Individual measurements often result in values of zero or negative numbers because of statistical fluctuations in the measurements. Although a negative value does not represent a physical reality. a valid long-term average of many measurements can be obtained only if the very small ${ }^{\text {as }}$ values are included in the population. For this reason, the primary value given in the tables of air sampling results is the actual value obtained from an individual measurement or group of measurements. These primary values are those used in making subsequent statistical analyses and in evaluating the real environmental impact of Laboratory operations.

Station and group means are weighted for the length of each sampling period and for the air volume sampled. The means were calculated using the following equation. ${ }^{\mathrm{B}}$

$$
\bar{c}=\frac{\sum_{i=1}^{N} v_{i} t_{i} c_{i}}{\sum_{i=1}^{N} v_{i} t_{i}}
$$

where

$\vec{c}=$ annual mean station or group atmospheric radioactive species concentration.

$c_{\mathfrak{s}}=$ atmospheric radioactive species concentration for station or group $i$ during $t_{1}$,

$\mathrm{N}=$ total number of samples during 1979 for a station or group,

$t_{1}=$ length of routine sampling perjod for station or group $i$, and

$v_{1}=$ air volume sampled for station or group i during $t_{1}$

Standard deviations for station and group means are similarly weighted by using the following equation.

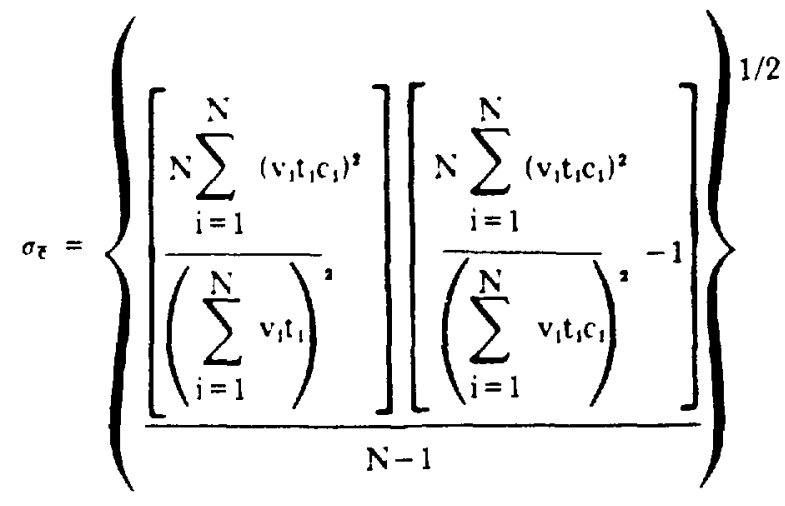

where

$\sigma_{\bar{c}}=$ standard deviation of $\overline{\mathrm{c}}$.

To indicate the precision of the maximum and minimums, an uncertainty term representing twice the propagated measurement uncertainty $(2 \sigma)$ associated with the reported maximum or minimum value is included in the data tables.

\section{Water, Soil, and Sediment Sampling}

Surface and ground water sampling points are grouped according to location and hydrologic similarity; i.e., regional, perimeter, and onsite stations. Surface and ground water grab samples are taken one to two times annually. Samples from wells are collected after sufficient pumpage or bailing to ensure that the sample is representative of the water in the aquifer. Spring samples (ground water) are collected at point of discharge.

The water samples are collected in $4 \ell$ (for radiochemical) and $1 \ell$ (for chemical) polyethylene bottles. The $4 \ell$ bottles are acidified in the field with $5 \mathrm{~m} \ell$ of concentrated nitric acid and returned to the laboratory within a few hours for filtration through a $0.45 \mu \mathrm{m}$ pore membrane filter. The samples are analyzed radiochemically for dissolved cesium ( ${ }^{127} \mathrm{Cs}$ ), plutonium ( ${ }^{2 n} \mathrm{Pu}$ and ${ }^{20} \mathrm{Pu}$ ), and tritium as HTO, as well as for total dissolved gross alpha, beta, and gamma activities. Total uranium is measured using the neutron activation method.

Water is collected for chemical analyses at the same time as for radiochemical analysis and returned to the laboratory for filtration. Samples for 
trace constiduents in the wacer supply are collected and aciditicel in the fiedel and returned immediately wo the laboralory for filtration.

soil and sediment stations are aloo grouped ace rording lo location and hydrologic similarity; i.e., regiomal, perimeter, and onsite stations.

ciril amples are collected by taking five plugs, 75 mm in dianetrer and in inm deep, at the center and erroers of a sefuare area $10 \mathrm{~m}$ on a side. The five pluge are combined to form a compesite sample for radinchemieal analyes. Sediment samples are colleceded from dune buildup behind boulders in the main rhanmels of peromnially flowing streams. Siamples from the bedsof intermitenty flowing st reams are colleceted acrose the main channel. The soil and sedimene samples are amalyoed for gross alpha and

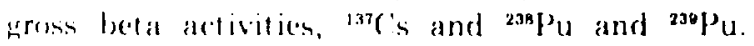
Moisture distillod from soil samples is analyoed for "H. A few solect samples are analyzed for ${ }^{\circ}$ Sr.

('umulative samplers are set in a dry stream to collect samples of intermittent storm runoff. The iampler comsists of a heavy angle iron driven into the channel with a heavy polvethylene bottle at lached by a strap. The intake nozzle to the bottle, comsist ing of a 1 cm diam (onpper tube fitted through the phastic bottle cap, faces upst ream and is placed about $1 \mathrm{~cm}$ above the channel. A vent hole $10.4 \mathrm{~cm}$ diam) is drilled into the bottle neck to vent air dur. ing initial filling of the sampler and to allow some (ontinuous circulation of water and sediments into the bottle. 'Ihe average time to fill the sampler is about 2 miri however, this can vary considerably, depending on the volume and velocity of flow.

The samples are filtered through a $0.45 \mu \mathrm{m}$ filter. The radioactivity and chemical composition of the solution is defined as filtrate passing through the filter, while the radioactivity is suspended sediments is defined as the residue on the filter.

The average concentrations of radionuclides and chemical constituents are reported for a number of individual analyses in Tables E-XIII through E-XVI and Tables E-XVIII and E-XX. The minimum and maximum values reported are individual analyses in the gromps, while the average is computed from all of the individual analyses in the group. The uncertainty following the primary value represents twice the standard deviation of the distribution rof observed values, or the analytical variation for individual results.

\section{REFERENCES}

H1. H. F. Johns and I. R. Cunningham, The

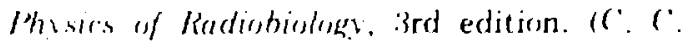
Thomas, Springfielel, Illinois, 1974) and Inconational ('ommission on Radiological Protec. lion (IC'RI"), "I'rotertion Against Jonizing Radiation from Exiernal Sources," IC'IRl" Rejourt Vo. lis llergamon Press, Lew York. $137(1))$.

3i2. P. IR. Bevington, Jata Rodurtion and Eirrur Anolusis for the Phusical Serenees, Meciraw. Hill. New York l1969).

B3: National Bureau of Sitandards Handbook 91 . Exporimental Statistics, National Bureau of Sitandards (August 1. 196.3).

B4. "Biomedical and Finvirommental Research Jrogram of the I.ASI. Health Jivision. January-December, 1979, I as Alamos Scientific Iaboratory progress report to be published).

Bi. R. O. (iilbert, Rocommendations (oncerning the c'omputation and Reporting of Counting Statistics for the Neuda Applied Ecolog. Giroup, BNWL-B-368, Battelle, Pacific Northwest Laboratories, Richland, Washington, September 1975.

B6. N. (. Barford, Experimental Measurements: Procision. Error and Truth, Addison-Wesley Publishing Co., Inc., London, p. 32 (1962). 


\section{APPENDIX $C$}

\section{ANALYTICAL CHEMISTKY METHODS}

\section{Procedures}

a. Plutonium and Americium. Soil and sedi. ment amples are dried, sieved through a Do. l2 acreen $1<1.7 \mathrm{~mm}$. and split into $10 \mathrm{~g}$ aliquests. Faach aliquen is leached with $\mathrm{HF}-\mathrm{H} . \mathrm{NO} \mathrm{O}_{3}$.

Waters are acidified to $-1 \% \mathrm{H}_{\mathrm{NO}}$ in the field. Immediately uprm arrival in the laboratory, they are filtered through $0.45 \mu \mathrm{m}$ pore membrane filters. split into 500 $\mathrm{m} \boldsymbol{l}$ aliquots, and evaporated to drynesis with $\mathrm{HNO}$. The residue is treated with $\mathrm{HF}$ (1) dissculve silica.

Air filters are ignited in platinum dishes, treated with $\mathrm{HF}-\mathrm{HNO}$, to dissolve silica, wet ashed with $\mathrm{H} \mathrm{NO})_{3} \cdot \mathrm{H}_{2}\left(\mathrm{O}_{2}\right.$ to decompose the organic residue and treated with $\mathrm{HNO}_{3} \cdot \mathrm{HCl}$ to ensure isotopic equilibrium.

Vegetation samples are ashed in a high temperature wen and then truated like soil samples. All samples are spiked with standardized ${ }^{242} \mathrm{Pu}$ and ${ }^{203} \mathrm{Am}$ during dissolution to serve as a chemical recovery tracer.

Dissolved samples are thoroughly digested in 7.2 $\mathrm{NHNO}$, and $1 \mathrm{~N} \mathrm{NaNO}_{2}$ added to ensure that $\mathrm{Pu}$ is in the tetravalent state. The solution is passed through a preconditioned anion exchange column. The initial eluate and the first $20 \mathrm{~m} \ell$ of a $7.2 \mathrm{~N}$ $\mathrm{HNO}_{3}$ wash is saved for ${ }^{241} \mathrm{Am}$ analysis. The column is then washed with $7.2 \mathrm{~N} \mathrm{HNO}_{3}$ and $8 \mathrm{~N} \mathrm{HCl}$. Plutonium is eluted with a freshly prepared solution of $1 \mathrm{~g} / \ell \mathrm{NH}_{4} \mathrm{I}$ in $1 \mathrm{~N} \mathrm{HCl}$. The eluate is appropriately conditioned and $\mathrm{Pu}$ is electrodeposited from a $4 \%$ solution of $\left(\mathrm{NH}_{4}\right)_{2} \mathrm{C}_{2} \mathrm{O}_{4}$. The plated $\mathrm{Pu}$ is counted on an alpha spectrometer. Values reported for ${ }^{230} \mathrm{Pu}$ are the sum of ${ }^{230} \mathrm{Pu}$ and ${ }^{200} \mathrm{Pu}$, since both have identical alpha energies.

For water and air filter samples, the eluate from the $\mathrm{Pu}$ column is conditioned to ensure the removal of $\mathrm{HNO}_{3}$ and adjusted to $0.5 \mathrm{~N} \mathrm{HCl}$. This solution is loaded on a cation exchange colunin, rinsed with 0.5 $\triangle H(1$ followed by $20 \mathrm{XHCl}$, and $\mathrm{Am}$ is eluted with $4 \mathrm{HO}$. The eluate is converted to the nitrate, made fi $\mathrm{I}$ with $\mathrm{H} . \mathrm{NO}_{3}$, then mixed with ethanol in the proportion $40 \%$ o $\mathrm{N} \mathrm{HNO}_{3}-60 \%$ ethanol, and loaded on a preconditioned anion exchange column. The column is washed with $75 \%$ methanol-25\% $6 \mathrm{I}$ $\mathrm{H} \mathrm{N}\left(\mathrm{O}_{3}\right.$, and $60 \%$ methanol-40\% $6 \mathrm{~N} \mathrm{HNO}_{3}$. Americium is eluted with $60 \%$ methanol-40\% $2.5 \mathrm{~N}$ $\mathrm{HN}_{3}$. This oomaqueous solvent-anion exchange step sejurates the rare carth elements, other ac. tinides. and Ra from Am.

For soil and vegetation samples the eluate from the Pu column is converted to $6 \mathrm{~N} \mathrm{H(')}$. Americium is extracted intol0.015 N I)EHPP and then loack extracted with $\left(\mathrm{NH}_{4}\right)_{2} \mathrm{C}^{\circ} \mathrm{O}_{3}$. The back extract is decomprosed with $\mathrm{HCl}, \mathrm{HNO}_{3}$, and $\mathrm{HClO}_{4}$, dissolved in $3 \mathrm{~N}$ $\mathrm{HC}$ ' $\mathrm{l}$. The solution is brought to:3 $\mathrm{N}$ in $\mathrm{HF}$ and $\mathrm{Am}$ is croprecipitated with $\mathrm{YF}_{3}$. The $\mathrm{YF}_{3}$ is dissolved with $\left.\mathrm{H}_{3} \mathrm{BO}\right)_{3}$ in $\left.6 \mathrm{~N} \mathrm{H.NO}\right)_{3}$, then mixed with ethanol in the proport iron 4()$\%$ 6 $\mathrm{V} \mathrm{HNO}_{3}-60 \%$ ethanol, and loaded on a preconditioned anion exchange column. The column is washed with $75 \%$ methanol-25\% $6 \mathrm{~N}$ $\mathrm{HNO}_{3}$ and $60 \%$ methanol-40\% $6 \mathrm{~N} \mathrm{HNO}_{3}$. Americium is eluted with $60 \%$ methanol. $40 \% 2.5 \mathrm{~N}$ $\mathrm{HNO}_{3}$. This nonaqueous solvent-anion exchange step separates the rare earth elements, other actinides, and $\mathrm{Ra}$ from $\mathrm{Am}$. The Am effluent is evaporated and dissolved in $2 \mathrm{~m} \ell \mathrm{HCl}$ and $2 \mathrm{~m} \ell 6 \mathrm{~N}$ $\mathrm{NH}_{4} \mathrm{SCN}$, the $\mathrm{pH}$ is adjusted to $\sim 3$ with $\mathrm{NH}_{4} \mathrm{OH}$. The adjusted sample is loaded on a preconditioned anion exchange column. The column is washed with $2 \mathrm{~N}$ NH,SCN to separate rare earth elements. Americium is eluted with $2 \mathrm{~N} \mathrm{HCl}$.

Air and water sample eluates from the methanol. $\mathrm{HNO}_{3}$ column and soil and vegetation sample eluates from the $\mathrm{SCN}$ - column are conditioned and Am electrodeposited from $5 \mathrm{~N} \mathrm{NH}$ the methyl red endpoint. Electrodeposited An is counted on an alpha spectrometer. 
b. Gross Alpha and Beta. T'wo gof sril or sedi. ment are leached in hot HAO( $)_{3}-H(1$, and the supernate is transforred to a stainless st eel planchet and dried for counting.

Vine hundred $\mathrm{m} \ell$ of water are acidified with $5 \mathrm{~m} \ell$ of $\mathrm{H} . \mathrm{NO})_{3}$ and evaporated to dryness. The residue is treated with $\mathrm{HF}-\mathrm{H} \mathrm{NO}_{3}$ to dissolve silica, and $\mathrm{H}_{2} \mathrm{O}_{2}$ and $\mathrm{H}_{\mathrm{N}} \mathrm{O}_{\mathrm{a}}(\mathrm{w}$ destroy organics. Residue is dissolved in $7.2 . \mathrm{H} H . \mathrm{VO}$, and then transferred of a counting planched.

Air filtors are mounted directly on counting phanchots.

Simples appropriately loaded on the planchets are crunted on a thin window, dual channel gas prowrtional counter. Activity is calculated with ap. propriate corroctions for cross talk between the two chitmeels and the edfect of mass leading on the counting efficioney.

c. Tritium. Sisils: are heated to evaporate the sril misture, the condensate is trapped, and $5 \mathrm{ml}$ aliquots are transferred to scintillation vials.

Water samples are acidified $10 \sim 1 \% \mathrm{HNO}_{3}$ in the field and filtered through $0.45 \mu \mathrm{m}$ pore membrane filters immediately upon arrival in the laboratory. Five $m \ell$ of the water are transferred into a scintilla tion cesunting vial.

Atmospheric water is trapped in a desiccator in the field. Moist ure is removed from desiccant in the laboratory, and appropriate aliquots taken for scintillation counting. Fifteen $m \boldsymbol{\ell}$ of scintillation liquid are added to each sample, which is then vigorously shaken.

Samples are counted in a liquid scintillation counter for $50 \mathrm{~min}$ or 10000 counts, whichever comes first. Standards and blanks are counted in conjunction with each set of samples.

d. ${ }^{137}$ 's and Gross Gamma. Soils and sediments are sieved through a No. $12(<1.7 \mathrm{~mm})$ screen. One hundred grams of the sieved soils are weighed into polvethylene bottles.

Water samples are acidified in the field to $\sim 1 \%$ $\mathrm{HNO}_{3}$ and filtered through $0.45, \mu \mathrm{m}$ pore membrane filters. Five hundred $m \ell$ of each sample are transferred to a standard $500 \mathrm{~m} \ell$ polyethylene bottle for counting.

The radionuclide ${ }^{137} \mathrm{Cs}$ is determined by counting on a Ge(Li) detector coupled to a multichannel analyzer. The activity is calculated by direct comparisrs with standards prepared in the same geometrical configuration as the samples. Ciross gamma is measured by counting in an NaloTll well counter, which acoummodates the $500 \mathrm{~m} \ell$ bottles. A single channel analyer arljusted wo register gamma radiation between 1 and $2 . M-9$ is interfaced to the detector Geroso gamma determinations are reported as net counts per unit time and unit weight.

e. "Sr. Sianple preparation and dissolutions are similar to those described in the section on Pu. After dissolution, the residue is dissolved in $\mathrm{HC}$ (1, the $\mathrm{pH}$ is adjusted to 2 , and $Y$ is separated from tir by extraction into $20 \%$ HI)FHI' in toluene. 'The isolated "Sir is left undisturbed for two weeks to allow the daughter ${ }^{\text {sin }} \mathrm{Y}$ to attain radioactive equilibrium. After that peried, inactive $Y$ carrier is adeled and ${ }^{\text {on }} \mathrm{Y}$ is again extracted from "sr by solvent extraction inte $5 \% \mathrm{HIFH}^{2}$ in toluene. Yitrium is back extracted into : $\mathrm{N} \mathrm{H} . \mathrm{NO}_{3}$ and precipitated as the hydroxide. Yitrium hydroxide is redissolved and the oxalate is precipitated. This precipitate is oven fired to the oxide which is filtered and weighed to determine the chemical yield. Yitrium oxide precipitate is counted on a gas proportional counter to measure the ac1ivity. Samples are recounted after three days to verify the separation of ${ }^{\text {no }} \mathrm{f}$ from other beta-emitting nuclides.

f. Uranium. Analyses for l: were performed in one of two ways instrumental epithermal neutron activation analysis or delayed neutron activation anaivsis. In the first method, two gram samples are irradiated in the epithermal neutron port at the Los Alamos Omega West Reactor. A period of two to four days is allowed to pass after the irradiatic and the samples are counted on a Ge(Li) gamma-ray spectrometer. The 228 and $278 \mathrm{keV}$ transitions from ${ }^{239} \mathrm{~Np}$ are used for the quantitative determination. The nuclear reaction is ${ }^{238} \mathrm{U}(\mathrm{n}, \gamma) \rightarrow{ }^{230} \mathrm{~Np}+\beta$. Obviously the ratio measures the major isotope of $U$ and calculates total $U$ assuming ${ }^{238} \mathrm{U}$ is $>99 \%$ of the total $\mathrm{L}$. This assumed value wil] nrobably not vary significantly in environmental samples.

For samples with $U$ concentrations greater than $100 \mathrm{ppm}$, another epithermal irradiation may be used. Folowing a $5 \mathrm{~min}$ irradiation and $10 \mathrm{~min}$ 
decay, the is kel kamma ray from ${ }^{230}{ }^{\prime}$ may be observed direcely rather than waiting for the total decay of ${ }^{230} \mathrm{~Np}$. Results from both epithermal methods have been reperted in the litesiture.

In the seesond method, samples are irradiated in a thermal neut ron port and pneumatically transferred (o) a neutron counter where the delayed neutrons produced hy the lission of ${ }^{2 a s}$ l' are measured 's 'The technique is very manpower efficient and has a lower limit of decection than does the epithermal irradiation method. However, total l' is calculated assuming a ${ }^{235} \mathrm{C}^{\circ} /{ }^{234} \mathrm{I}$ ratjo of 0.01072 . Variations in this ratio will produce inaceuracies in the result. hence samples likely to contain depleted l' were not analyzed by this method because of the lower limits of retection. Most of our I analyses aredone by this methed because it is the more semsitive.

An advantage to having heith l' techniefues available is that samples containing onriched l may' be measured. 'The ${ }^{236}$ ( content may be determined by delayed neut rons and the ${ }^{239}$ ' content by epither. mal activation. 'Total l' is the sum of these, and a rough indication of the isotupe satio may also be given.

A comparison of these methods with the more traditional fluorometric tochnique for $l^{\prime}$ analysis in soils ha: been published."

\section{Stable Filements}

Four instrumental methods are used for a wide variety of stable elenent determinations. Veutron activation and atomic absorption are the principal techniques with ion chromatography, ion selective electrodes, and combustion analysis used in a supplementary role. Flements and anions determined hy the various methods are summarized in Table ( . I. In addition, standard chemical methods are used for $\mathrm{H}\left(\mathrm{CO}_{3}{ }^{2}\right.$. tot al dissolved solids (TIDS), and total hardness. It should be noted that our $\mathrm{H}_{h}$ method of choice is cold vapor atomic absorption using the standard Perkin-Flmer technique.

\section{Analytical Chemistry Quality Evaluation Program}

Control samples are analyzed in conjunction with the normal analytical chemistry workload. Such samples consist of two general types. Blanks are matrix materials comtaining quantities of analy!e below the defection limit of the analytical procerfure. Standards are materials containing known quant ities of the analye. Analyses of control simples illl 1 wo needs in the analytical work. First, they provide quality control over the analytical procedures sot that problems that might oceur can be identilied and correced. Secondly, data obtained from the analvin of coutrol samples permits the waluation of the capabilities of a particular analytical techmique under a certain set of circumstances. The former function is one of analytical control. the later is ralled qualuty assurance.

Quality cont rol samples are oblained from out side agences and prepared internally. The El'A provides water. foudstuff, and air filter standards for analysis cif gross alpha. irosis bet a. ${ }^{3} \mathrm{H},{ }^{137} \mathrm{Cs}$, and ${ }^{239} \mathrm{P} n$ as part ut the ongendus laburatury intercomparison program. The Fovirmmental Measurements Iaboratory (F.l11.) provides wil, water, home, tissue, vegetation. and air filder samples each containing a wide variety of radonuclides. These are part of a laboratory inceroomparison of J)(OF-supported facilities. I rambum standards obtained from the Canadian cienlogical Survey (C) national Atomic Fonergy Agency (IAFA) are used to evaluate the uranium analysis procedures. Internal standards aro prepared by adding known yuantities of analote to blank matrix materials.

Quality assurance for the stable clement analysis program is maintained by the analysis of certified or well-characterized envirommental materials. The Vational Burcau of Standards (NBSi) has a large set o'silicate. water. and hiological Standard Reference viaterials (SRM). The FPA distributes mineral analysis and trace analysis water standards. Rock and soil certified st andards have been obtained from the ('is and the Inited Sitates Ceological Survey llis(is). Other trace elemental standards have been purchases from a private company.

Vo attempt is made to make control samples unknown to the analyst. However, they are submitted to the laboratory at regular intertals and analyzed in assoriation with other samples; i.e., they are not normally handled as a unique set of samples. We feel that it would he difficult for the analyst to give the samples special attention even if they were so inclined. We endeavor to run at least $10 \%$ of the 
TABLE C-I

\section{ANALYTICAL METHODS FOR VARIOUS ELEMENTS ANI) ANIONS}

\begin{tabular}{|c|c|c|}
\hline Technique & Elements/Anions Measured & References \\
\hline $\begin{array}{l}\text { Neutron Activation } \\
\text { Instrumental Thermal }\end{array}$ & $\begin{array}{l}\mathrm{Al}, \mathrm{Sb}, \mathrm{As}, \mathrm{Ba}, \mathrm{Br}, \mathrm{Ca}, \mathrm{Ce}, \mathrm{Cs}, \mathrm{Cl}, \mathrm{Cr} \text {, } \\
\mathrm{Co}, \mathrm{Dy}, \mathrm{Eu}, \mathrm{Au}, \mathrm{Hf}, \mathrm{In}, \mathrm{I}, \mathrm{Fe}, \mathrm{La}, \mathrm{Lu} \text {, } \\
\mathrm{Mg}, \mathrm{Mn}, \mathrm{K}, \mathrm{Rb}, \mathrm{Sm}, \mathrm{Sc}, \mathrm{Se}, \mathrm{Na}, \mathrm{Sr}, \mathrm{S} \text {, } \\
\mathrm{Ta}, \mathrm{Tb}, \mathrm{Th}, \mathrm{Ti}, \mathrm{W}, \mathrm{V}, \mathrm{Yb}, \mathrm{Zn}\end{array}$ & $\mathrm{C} 1,5,6,7,8$ \\
\hline Instrumental Epithermal & $\begin{array}{l}\mathrm{Al}, \mathrm{Sb}, \mathrm{As}, \mathrm{Ba}, \mathrm{Br}, \mathrm{Cs}, \mathrm{Cr}, \mathrm{F}, \mathrm{Ga}, \mathrm{Au} \\
\mathrm{In}, \mathrm{I}, \mathrm{La}, \mathrm{Mg}, \mathrm{Mn}, \mathrm{Mo}, \mathrm{Ni}, \mathrm{K}, \mathrm{Sm}, \mathrm{Se} \\
\mathrm{Si}, \mathrm{Na}, \mathrm{Sr}, \mathrm{Th}, \mathrm{Ti}, \mathrm{W}, \mathrm{U}, \mathrm{Zn}, \mathrm{Zr}\end{array}$ & $\mathrm{C} 1,9,10,11,12,13,14$ \\
\hline $\begin{array}{l}\text { Thermal Neutron Capture- } \\
\text { Gamma Ray }\end{array}$ & $\begin{array}{l}\mathrm{Al}, \mathrm{B}, \mathrm{Ca}, \mathrm{Cd}, \mathrm{C}, \mathrm{Gd}, \mathrm{H}, \mathrm{Fe}, \mathrm{Mg} \\
\mathrm{N}, \mathrm{P}, \mathrm{K}, \mathrm{Si}, \mathrm{Na}, \mathrm{S}, \mathrm{Ti}\end{array}$ & $\begin{array}{l}C 1,15,16,17,18 \\
19,20,21,22\end{array}$ \\
\hline Radiochemical & $\begin{array}{l}\mathrm{Sb}, \mathrm{As}, \mathrm{Cu}, \mathrm{Au}, \mathrm{Ir}, \mathrm{Hg}, \mathrm{Mo}, \mathrm{Os}, \mathrm{Pd} \\
\mathrm{Pt}, \mathrm{Ru}, \mathrm{Se}, \mathrm{Ag}, \mathrm{Te}, \mathrm{Th}, \mathrm{W}, \mathrm{U}\end{array}$ & $\begin{array}{l}\mathrm{C} 1,23,24,25,26 \\
27,28,29,30\end{array}$ \\
\hline Atomic Absorption & $\begin{array}{l}\mathrm{Sb}, \mathrm{As}, \mathrm{Ba}, \mathrm{Be}, \mathrm{Bi}, \mathrm{Cd}, \mathrm{Ca}, \mathrm{Cr}, \mathrm{Co}, \mathrm{Cu} \\
\mathrm{F}, \mathrm{Ga}, \mathrm{In}, \mathrm{Fe}, \mathrm{Pb}, \mathrm{Li}, \mathrm{Mg}, \mathrm{Mn}, \mathrm{Hg}, \mathrm{Mo} \text {, } \\
\mathrm{Ni}, \mathrm{K}, \mathrm{Se}, \mathrm{Si}, \mathrm{Ag}, \mathrm{Na}, \mathrm{Sr}, \mathrm{Te}, \mathrm{Tl}, \mathrm{Sn}, \\
\text { Ti,V,Zn }\end{array}$ & $\begin{array}{l}\text { C31,32,33,34,35, } \\
36,37,38\end{array}$ \\
\hline Ion Chromatograpiny & $\begin{array}{l}\mathrm{F}^{-}, \mathrm{Cl}^{-}, \mathrm{B}_{i^{-}}^{-}, \mathrm{NO}_{2}^{-}, \mathrm{NO}_{-3}^{-} \\
\mathrm{SO}_{-2}^{-2} \mathrm{SO}_{-2}^{-2}, \mathrm{PO}_{4}^{-3}\end{array}$ & C39 \\
\hline Ion Selective Electrodes & $\mathrm{F}^{-}, \mathrm{NH}+$ & $\mathrm{C} 40$ \\
\hline Combustion & $\mathrm{C}, \mathrm{N}, \mathrm{H}$ & $\mathrm{C} 22$ \\
\hline
\end{tabular}

stable element analyses as quality assurance samples using the materials described above. A more detailed description of our Quality Assurance Program using SRM is in preparation.

The capabilities of the analytical procedures are evaluated from the quality control samples. Accuracy and precision are evaluated from results of analysis of standards. These results are normalized to the known quantity in the standard to permit comparison between standards containing different quantities of the analyte:

$R=\frac{\text { Reported Quantity }}{\text { Known Quantity }}$
A mean value of $(\bar{x})$ of $R$ for all analyses of a given type is calculated by weighting each value $\left(\bar{x}_{1}\right)$ by the uncertainty associated with it $\left(s_{i}\right)$.

$\bar{x}=\frac{\Sigma_{1} \bar{x}_{1} / s_{1}^{2}}{\Sigma_{1} 1 / s_{1}^{2}}$

The standard-deviation (s) of the weighted mean is calculated assuming a normal distribution.

$$
s=\sqrt{\frac{\Sigma_{1}\left(x-x_{1}\right)^{2}}{N-1}}
$$


These calculated values are presented in Tables $\mathrm{C}$-II and C-III. The weighted mean of the $\mathrm{R}$ is a measure of the accuracy of the procedure. Values of $\mathbf{R}$ greater than unity indicate a positive bias and values less than unity, a negative bias in the analysis. The standard deviation is a measure of the precision. The precision is a function of the quantity of analyte; i.e., as the absolute quantity approaches the limit of detection, the precision increases. For instance, the precision for ${ }^{137} \mathrm{Cs}$ determinations is quite large because many of the standards approached the limits of detection of the measurement. Conversely, the precision for the uranium analyses is unrealistically small because the staildards contained quantities of uranium significantly above the detection limits.

Analysis of blanks provides a criterion to judge the probability that samples were contaminated during the analysis. Table C-IV presented weighted means and standard deviations of the absolute quantity of analyte reported in blank materials analyzed during 1979 .

\section{Limits of Detection}

Data from the analysis of blanks also providu a means of calculating limits of detection for the various procedures. Table C-V presents detection limits for analyses of various constituents in several environmental matrices. The limits for ${ }^{200,250} \mathrm{Pu}$, ${ }^{241} \mathrm{Am},{ }^{137} \mathrm{Cs}$, and $\mathrm{U}$ are calculated from the weighted mean plus two standard deviations of the analysis of blanks (Table C-IV). For tritium, the detection limit is merely $2 \mathbf{s}$ of repetitive determinations of the instrumental blank. Gross alpha and gross beta are measured simultaneously by counting on a gas proportional counter and electronically discriminating the output pulses. As there is crosstalk generated by the detection of the two types of emissions, the detection lini:t of one is a function of the counting rate of the other. Detection limits in Table C. $V$ are calculated assuming that counting rates for both alpha and beta are at background levels. The detection limit for alpha increases $10 \%$ above the limit for every count per minute (cpm) of beta activity emitted by the sample. Similarly, the detection limit for beta increases $40 \%$ for every $10 \mathrm{cpm}$ of alpha.

For most routine water samples, concentrations of ${ }^{137} \mathrm{Cs}$ were determined with a $\mathrm{NaI}(\mathrm{Tl})$ well counter. An automatic sample changer used in conjunction with the system signficantly reduced the cost of the analyses. However, the smaller volume and higher background associated with the $\mathrm{NaI}(\mathrm{Tl})$ detector significantly degraded the limit of sensitivity for this analysis. No blanks were measured to assess these limits, but they are estimated to be an order of magnitude greater than that given in Table C-IV, which was determined by counting $500 \mathrm{~m} \ell$ samples on a $\mathrm{Ge}(\mathrm{Li})$ detector.

Results greater than the defined detection limits indicate the presence of the constituent at the $95 \%$ confidence level. However, results less than the detection limit do not necessarily indicate its absence. 


\begin{tabular}{|c|c|c|c|c|c|c|c|c|}
\hline \multirow[b]{2}{*}{ Eiement } & \multicolumn{2}{|c|}{ Soil } & \multicolumn{2}{|c|}{ Water } & \multicolumn{2}{|c|}{ Vegetation } & \multicolumn{2}{|c|}{ Air Particulates } \\
\hline & $\begin{array}{c}R^{*} \\
\left(\bar{x} \pm{ }^{0}\right)\end{array}$ & $\begin{array}{l}\text { No. Deter- } \\
\text { minations }\end{array}$ & $\begin{array}{c}\mathbf{R}^{*} \\
\left(\bar{x} \pm \omega^{b}\right)\end{array}$ & $\begin{array}{l}\text { No. Deter- } \\
\text { minations }\end{array}$ & $\begin{array}{c}R \cdot \\
(\bar{x} \pm 0)\end{array}$ & $\begin{array}{l}\text { No. Deter- } \\
\text { minations }\end{array}$ & $\begin{array}{c}A^{*} \\
(\bar{x} \pm \oplus)\end{array}$ & $\begin{array}{l}\text { No. Deter- } \\
\text { minatione }\end{array}$ \\
\hline Ag & $1.04 \pm 0.05$ & 12 & & 0 & & 0 & & 0 \\
\hline Al & $1.00 \pm 0.03$ & 18 & & 0 & & 0 & $0.95 \pm 0.05$ & 5 \\
\hline As & $1.01 \pm 0.11$ & 35 & $0.95 \pm 0.11$ & 31 & & 0 & 1.04 & 2 \\
\hline $\mathrm{Ha}$ & $1.19 \pm 0.26$ & 21 & & 0 & & 0 & & 0 \\
\hline $\mathrm{Be}$ & & 0 & $1.11 \pm 0.16$ & 16 & & 0 & & 0 \\
\hline $\mathrm{Br}$ & & $\mathbf{0}$ & & 0 & $1.06 \pm 0.07$ & 14 & $1.05 \pm 0.05$ & 6 \\
\hline $\mathrm{Ca}$ & $1.03 \pm 0.03$ & 3 & $1.18 \pm 0.17$ & 21 & & 0 & & 0 \\
\hline $\mathrm{Cd}$ & & 0 & $1.00 \pm 0.21$ & 42 & & 0 & & $\mathbf{0}$ \\
\hline $\mathrm{Ce}$ & 1.08 & 1 & & 0 & & 0 & & 0 \\
\hline $\mathrm{Cl}$ & & 0 & $1.07 \pm 0.11$ & 65 & 0.96 & 2 & $1.10 \pm 0.15$ & 3 \\
\hline $\mathrm{Co}$ & $0.96 \pm 0.11$ & 16 & $0.96 \pm 0.13$ & 6 & & $\mathbf{0}$ & $2.33 \pm 0.39^{\circ}$ & 5 \\
\hline $\mathrm{Cr}$ & $1.08 \pm 0.09$ & 14 & $1.04 \pm 0.13$ & 32 & $0.86 \pm 0.06$ & 4 & $1.01 \pm 0.14$ & 6 \\
\hline $\mathrm{Cs}$ & $0.95 \pm 0.14$ & 15 & & 0 & & 0 & & 0 \\
\hline $\mathrm{Cu}$ & $0.99 \pm 0.25$ & 44 & $0.94 \pm 0.04$ & 12 & & 0 & & 0 \\
\hline Eu & 0.98 & 2 & & 0 & & $\mathbf{0}$ & & 0 \\
\hline$F$ & & 0 & $1.07 \pm 0.20$ & 17 & & 0 & & 0 \\
\hline $\mathrm{Fe}$ & $0.98 \pm 0.06$ & 30 & $0.99 \pm 0.05$ & 12 & $0.99 \pm 0.16$ & 12 & $0.96 \pm 0.13$ & 6 \\
\hline $\mathrm{Ge}$ & $0.88 \pm 0.02$ & 3 & & 0 & & 0 & & 0 \\
\hline $\mathrm{Hg}$ & 0.88 & 2 & $0.97 \pm 0.04$ & 7 & & 0 & & 0 \\
\hline $\mathrm{K}$ & $1.10 \pm 0.10$ & 6 & $1.02 \pm 0.05$ & 18 & & 0 & $1.11 \pm 0.08$ & 4 \\
\hline $\mathrm{La}$ & $0.96 \pm 0.09$ & 8 & & 0 & & 0 & $0.91 \pm 0.08$ & 6 \\
\hline Lu & 1.10 & 1 & & 0 & & 0 & & 0 \\
\hline $\mathrm{Mg}$ & & 0 & $1.01 \pm 0.07$ & 14 & & 0 & & 0 \\
\hline$M n$ & $0.99 \pm 0.04$ & 10 & $0.97 \pm 0.08$ & 6 & & 0 & & 0 \\
\hline Mo. & $0.94 \pm 0.46$ & 36 & & 0 & & 0 & & 0 \\
\hline $\mathrm{Na}:$ & 0.90 & 2 & $1.02 \pm 0.05$ & 6 & & 0 & & 0 \\
\hline $\mathrm{Pb}$ & $0.96 \pm 0.18$ & 24 & $1.03 \pm 0.11$ & 24 & & 0 & & 0 \\
\hline $\mathbf{R b}$ & $1.03 \pm 0.10$ & 17 & & 0 & $1.08 \pm 0.21$ & 12 & & 0 \\
\hline Sb & $1.06 \pm 0.19$ & 17 & & 0 & & 0 & & 0 \\
\hline Sc & 0.97 & 1 & & 0 & & 0 & & 0 \\
\hline Se & $0.96 \pm 0.11$ & 48 & $0.99 \pm 0.11$ & 18 & & 0 & & 0 \\
\hline $\mathbf{S j}$ & $0.97 \pm 0.07$ & 9 & & 0 & & 0 & & 0 \\
\hline So: & & 0 & $0.95 \pm 0.05$ & 47 & & 0 & & 0 \\
\hline $\mathrm{Ta}$ & $1.09 \pm 0.18$ & 14 & & 0 & & 0 & & 0 \\
\hline TDS & & 0 & $1.0 \pm 0.03$ & 5 & & 0 & & 0 \\
\hline $\mathrm{Th}$ & $\quad 1.06 \pm 0.03$ & 16 & & 0 & & 0 & & 0 \\
\hline $\mathrm{Ti}$ & $0.97 \pm 0.05$ & 7 & & 0 & & 0 & & 0 \\
\hline $\mathrm{U}$ & $0.99 \pm 0.06$ & 111 & $1.01 \pm 0.03$ & 32 & & 0 & & 0 \\
\hline $\mathrm{v}$ & $1.04 \pm 0.09$ & 17 & 1.10 & 2 & & 0 & $0.90 \pm 0.15$ & 5 \\
\hline $\mathbf{w}$ & $1.14 \pm 0.32$ & 21 & & $\overrightarrow{0}$ & & 0 & & 0 \\
\hline $\mathrm{Yb}$ & 1.00 & 1 & & 0 & & 0 & & 0 \\
\hline $\mathrm{Zn}$ & $0.86 \pm 0.07$ & 24 & $1.21 \pm 0.45$ & 12 & & 0 & $1.02 \pm 0.05$ & 4 \\
\hline
\end{tabular}

${ }^{-} \mathrm{R}$ is the weighted mean.

'Three or more samples required to calculate $\mathbf{s}$.

'Suspect NBS informational value may be in error. 
TABLE C-III

\section{RADIOCHEMICAL QUALITY ASSURANCE ON EPA AND EML PROGRAMS}

\begin{tabular}{|c|c|c|}
\hline Analysis & No. of Samples & $\begin{array}{c}\mathbf{R}^{\mathbf{x}} \\
\left(\overline{\mathbf{x}} \pm \mathbf{s}^{\mathbf{2}}\right) \\
\end{array}$ \\
\hline Alpha & 30 & $1.04 \pm 0.22$ \\
\hline Beta & 30 & $1.07 \pm 0.15$ \\
\hline${ }^{3} \mathrm{H}$ & 7 & $1.06 \pm 0.19$ \\
\hline${ }^{81} \mathrm{Cr}$ & 8 & $1.11 \pm 0.10$ \\
\hline${ }^{\circ 0} \mathrm{Co}$ & 14 & $1.08 \pm 1.13$ \\
\hline${ }^{\circ} \mathrm{Zn}$ & 6 & $3.25 \pm 1.04$ \\
\hline${ }^{\circ 0} \mathrm{Sr}$ & 35 & $0.99 \pm 0.26$ \\
\hline${ }^{\mathrm{is}} \mathrm{Cs}$ & 8 & $0.99 \pm 0.54$ \\
\hline${ }^{197} \mathrm{Cs}$ & 29 & $1.02 \pm 0.42$ \\
\hline${ }^{230} \mathrm{Pu}$ & 8 & $0.87 \pm 0.57$ \\
\hline $\mathrm{U}$, natural & 7 & $0.82 \pm 0.13$ \\
\hline
\end{tabular}

- $\mathrm{R}$ is the weighted mean.

TABLE C-IV

\section{QUANTITY OF CONSTITUENT REPORTED IN BLANKS}

\begin{tabular}{|c|c|c|c|}
\hline Analysis & $\begin{array}{c}\text { No. of } \\
\text { Samples }\end{array}$ & $\begin{array}{c}\text { Quantity } \\
\text { (Weighted Mean) } \\
(\bar{x} \pm 8) \\
\end{array}$ & Units \\
\hline${ }^{20} \mathrm{Sr}$ & 15 & $0.0055 \pm 0.06$ & $\mathrm{pCi}$ \\
\hline${ }^{197} \mathrm{Cs}$ & 26 & $1.2 \pm 11$ & $\mathrm{pCi}$ \\
\hline${ }^{200} \mathrm{Pu}$ & 23 & $-0.0064 \pm 0.069$ & $\mathrm{pCi}$ \\
\hline${ }^{200} \mathrm{Pu}$ & 23 & $0.0010 \pm 0.029$ & $\mathrm{pCi}$ \\
\hline${ }^{241} \mathrm{Am}$ & 6 & $0.019 \pm 0.013$ & $\mathrm{pCi}$ \\
\hline $\begin{array}{l}\text { Uraniunı } \\
\text { (Delayed neutron) }\end{array}$ & 4 & $15 \pm 6$ & ng \\
\hline $\begin{array}{l}\text { Uranium } \\
\text { (Epithermal activation) }\end{array}$ & 153 & $25 \pm 12$ & ng \\
\hline Gross alpha & 9 & $0.032 \pm 0.35$ & $\mathrm{pCi}$ \\
\hline Gross beta & 9 & $0.57 \pm 0.93$ & $\mathrm{pCi}$ \\
\hline
\end{tabular}


TABLE C-V

\section{DETECTION LIMITS FOR ANALYSES OF TYPIC:AI. ENVIRONMENTAL SAMPLES}

\begin{tabular}{|c|c|c|c|}
\hline Parameter & $\begin{array}{l}\text { Approximate Sample } \\
\text { Volume or Weight }\end{array}$ & $\begin{array}{l}\text { Count } \\
\text { Time }\end{array}$ & Concentration \\
\hline \multicolumn{4}{|l|}{ Air Sample } \\
\hline Tritium & $3 \mathrm{~m}^{3}$ & $100 \mathrm{~min}$ & $10^{-12} \mu \mathrm{Ci} / \mathrm{m} \ell$ \\
\hline${ }^{230} \mathrm{Pu}$ & $1.2 \times 10^{4} \mathrm{~m}^{2}$ & $8 \times 10^{4} \mathrm{~s}$ & $2 \times 10^{-18} \mu \mathrm{Ci} / \mathrm{ml}$ \\
\hline${ }^{239} \mathrm{Pu}$ & $1.2 \times 10^{4} \mathrm{~m}^{3}$ & $8 \times 10^{4} \mathrm{~s}$ & $3 \times 10^{-10} \mu \mathrm{Ci} / \mathrm{m} \ell$ \\
\hline${ }^{241} \mathrm{Am}$ & $2.5 \times 10^{\circ} \mathrm{m}^{\prime \prime}$ & $8 \times 10^{4} \mathrm{~s}$ & $2 \times 10^{-18} \mu \mathrm{Ci} / \mathrm{ml}$ \\
\hline Gross alpha & $3.8 \times 10^{1} \mathrm{~m}^{3}$ & $100 \mathrm{~min}$ & $3 \times 10^{-10} \mu / \mathrm{Ci} / \mathrm{m} \ell$ \\
\hline Gross beta & $3.8 \times 10^{3} \mathrm{~m}^{\prime}$ & $100 \mathrm{~min}$ & $3 \times 10^{-10} \mu \mathrm{Ci} / \mathrm{m} \ell$ \\
\hline $\begin{array}{l}\text { Uranium } \\
\text { (Delayed neutron) }\end{array}$ & $2.5 \times 10^{4} \mathrm{~m}^{2}$ & $60 \mathrm{~s}$ & $1 \mathrm{pg} / \mathrm{m}^{2}$ \\
\hline \multicolumn{4}{|l|}{ Water Sample } \\
\hline Tritium & $0.005 \ell$ & $100 \mathrm{~min}$ & $7 \times 10^{-7} \mu \mathrm{Ci} / \mathrm{ml}$ \\
\hline${ }^{137} \mathrm{Cs}$ & $0.5 \ell$ & $5 \times 10^{4} \mathrm{~g}$ & $4 \times 10^{-1} \mu \mathrm{Ci} / \mathrm{ml}$ \\
\hline${ }^{238} \mathrm{Pu}$ & $0.5 \ell$ & $8 \times 10^{4} \mathrm{~s}$ & $g \times 10^{-12} \mu \mathrm{Ci} / \mathrm{ml}$ \\
\hline${ }^{230} \mathrm{Pu}$ & $0.5 \ell$ & $8 \times 10^{4} 8$ & $3 \times 10^{-11} \mu \mathrm{Ci} / \mathrm{m} \ell$ \\
\hline${ }^{241} \mathrm{Am}$ & $0.5 \ell$ & $8 \times 10^{4} \mathrm{~s}$ & $2 \times 10^{-10} \mu \mathrm{Ci} / \mathrm{ml}$ \\
\hline Gross alpha & $0.9 \ell$ & $100 \mathrm{~min}$ & $1 \times 10^{-1} \mu \mathrm{Ci} / \mathrm{m} \ell$ \\
\hline Gross beta & $0.9 \ell$ & $100 \mathrm{~min}$ & $5 \times 10^{-1} \mu \mathrm{Ci} / \mathrm{ml}$ \\
\hline Uranium & $0.025 \ell$ & & $1 \mu \mathrm{g} / \mathrm{l}$ \\
\hline
\end{tabular}

\section{Soil Sample}

Tritium

${ }^{137} \mathrm{Cs}$

${ }^{236} \mathrm{Pu}$

${ }^{230} \mathrm{Pu}$

${ }^{241} \mathrm{Am}$

Gross alpha

Gross beta

Uranium

(Epithermal activation)

$1 \mathrm{~kg}$
$100 \mathrm{~g}$
10
10
10
2
2
2

$\begin{array}{cc}100 \mathrm{~min} & 0.003 \mathrm{pCi} / \mathrm{g} \\ 5 \times 10^{4} \mathrm{~s} & 10^{-1} \mathrm{pCi} / \mathrm{g} \\ 8 \times 10^{4} \mathrm{~s} & 0.003 \mathrm{pCi} / \mathrm{g} \\ 8 \times 10^{4} \mathrm{~s} & 0.002 \mathrm{pCi} / \mathrm{g} \\ 8 \times 10^{4} \mathrm{~s} & 0.01 \mathrm{pCi} / \mathrm{g} \\ 100 \mathrm{~min} & 0.8 \mathrm{pCi} / \mathrm{g} \\ 100 \mathrm{~min} & 0.003 \mathrm{pCi} / \mathrm{g} \\ & 0.03 \mu \mathrm{g} / \mathrm{g}\end{array}$




\section{REFERENCES}

C1. E. S. Gladney, D. B. Curtis, D. R. Perrin, J. W. Owens, and W. E. Goode, "Nuclear Techniques for the Chemical Analysis of Environmental Materials," Los Alamos Scientific Laboratory report LA-8192-MS, 1980.

C2. E. S. Gladney, J. W. Owens, and J. W. Starner, "Simultaneous Determination of Uranium and Thorium on Ores by Instrumental Epithermal Neutron Activation Analysis," Anal. Chim. Acta 104, 121 (1979).

C3. B. A. Amiel, "Analytical Applications of Delayed Neutron Emission in Fissionable Elements," Anal. Chem. 34, 1683 (1962).

C4. E. S. Gladney, W. K. Hensley, and M. M. Minor, "Comparison of Three Techniques for the Measurement of Depleted Uranium in Soils," Anal. Chem. 50, 652 (1978).

C5. G. E. Gordon, K. Randle, G. G. Goles, J. B. Corliss, M. H. Beeson, and S. S. Oxley, "Instrumental Activation Analysis of Standard Rocks with High Resolution $\gamma$-Ray Detectors," Geochim. et Cosmochim. Acta 32, 369 (1968).

C6. R. Dams, J. A. Robbins, K. A. Rahn, and J. W. Winchester, "Nondestructive Neutron Activation Analysis of Air Pollution Particulates," Anal. Chem. 42, 861 (1970).

C7. B. Salbu, E. Steinnes and A. C. Pappas, "Multielement Neutron Activation of Fresh Water Using Ge(Li) Gamma Spectrometry," Anal. Chem. 47, 1011 (1975).

C8. G. R. Van der Linden, F. DeCorte, and J. Hoste, "Activation Analysis of Biological Materials with Ruthenium as a Multi-Isotopic Comparator," Anal. Chim. Acta 71, 263 (1974).

C9. H. E. Steinnes, "Epithermal Neutron Activation Analysis of Geological Materials," in Activation Analysis in Geochemistry and Cosmochemistry, A. O. Brumfelt and E. Steinnes, Eds., UNIVERSITETSFORLAGET, Oslo, Norway, pp. 113-128 (1971).
C10. E. S. Gladney, L. E. Wangen, and R. D. Aguilar, "Comparison of Three Techniques for Rapid Determination of $\mathrm{Sr}$ in Soils and Vegetation," Anal. Lett. 10, 1083 (1977).

C11. L. E. Wangen and E. S. Gladney, "Determination of As and $\mathrm{Ga}$ in Standard Materials by Instrumental and Epithermal Neutron Activation Analysis," Anal. Chim. Acta 96, 271 (1978).

C12. E. S. Gladney, J. W. Owens, M. L. Marple, and D. R. Dreesen, "A Comparison of Thermal ard Epithermal Neutron Activation for the Measurement of Se in Vegetation," Anal. Lett. Al1, 1001 (1978).

C13. E. S. Gladney and D. R. Perrin, "Quantitative Analysis of Silicates by Instrumental Epithermal Neutron Activation Using (n,p) Reactions," Anal. Chem. 51, 2297 (1979).

C14. E. S. Gladney and D. R. Perrin, "Determination of Bromine in Biological, Soil, and Geological Standard Reference Materials by Instrumental Epithermal Neutron Activation Analysis," Anal. Chem. 51, 2015 (1979).

C15. E. S. Gladney, E. T. Jurney, and D. B. Curtis, "Nondestructive Determination of Boron and Cadmium in Environmental Materials by Thermal iveutron Prompt Gamma-Ray Spectrometry," Anal. Chem. 48, 2139 (1976).

C16. E. T. Jurney, D. B. Curtis, and E. S. Gladney, "Nondestructive Determination of Sulfur in Environmental Materials by Thermal Neutron Prompt Gamma-Ray Spectroscopy," Anal. Chem. 49, 1741 (1977).

C17. E. S. Gladney, D. B. Curtis, and E. T. Jurney, "Multielement Analysis of Major and Minor Elements by Thermal Neutron Capture Gamma-Ray Spectrometry," J. Radioanal. Chem. 46, 299 (1978).

C18. D. B. Curtis, E. S. Gladney, and E. T. Jurney, "Potential Interference in the Determination of Sulfur by Thermal Neutron Induced Prompt Gamma-Ray Spectrometry," Anal. Chem. 51, 158 (1979). 
C19. E. S. Gladney, D. B. Curtis, E. T. Jurney, "Simultaneous Determination of Nitrogen, Carbon, and Hydrogen Using Thermal Neutron Prompt Gamms-Ray Spectrometry," Anal. Chim. Acta 110, 339 (1979).

C20. E. S. Gladney, "A Literature Survey of Chemical Analysis by Thermal Neutron Induced Capture Gamma-Ray Spectrometry," Los Alamos Scientific Laboratory report LA8028-MS, Sept. 1979.

C21. M. P. Tailey, D. L. Anderson, W. H. Zoller, G. E. Gordon, and R. M. Lindstrom, "Neutron Capture Prompt Gamma-Ray Activation Analysis for Multielement Determination in Complex Samples," Anal. Chem. 51, 2209 (1979).

C22. T. G. Schofield, E. S. Gladney, F. R. Miera, and P. E. Trujillo, "Comparative Determination of Carbon, Nitrogen, and Hydrogen in Environmental Standard Reference Materials by Instrumental Combustion Analysis and Thermal Neutron Capture Gamma Ray Spectrometry," Anai. Lett. A13, in press, 1980.

C23. E. S. Gladney and H. L. Rook, "Determination of Tellurium and Uranium in Environmental Materials," Anal. Chem. 471554 (1975).

C24. E. S. Gladney, J. W. Owens, and J. W. Starner, "The Determination of Uranium in Natural Waters by Neutron Activation Analysis," Anal. Chem. 48, 973 (1976).

C25. E. S. Gladney, "Copper Determination in Standard Materials Using Neutron Activation and Srafion NMRR Anion Exchange Resin," Anal. Chim. Acta 91, 353 (1977).

C26. E. S. Gladney, "Determination of As, Sb, Mo, $T h$, and $W$ in Silicates by Thermal Neutron Activation and Inorganic Ion Exchange," Anal, Lett. A11, 429 (1978).

C27. E. S. Gladney and J. W. Owens, "Determination of As, W, and Sb in Natural Waters by Neutron Activation and Inorganic Ion Exchange," Anal. Chem. 48, 2220 (1976).
C28. R. A. Nadkarni and G. H. Morrison, "Determination of the Noble Metals in Geological Materials by Neutron Activation Analysis," Anal. Chem. 46, 232 (1974).

C29. R. A. Nadkarni and G. H. Morrison, "Determination of Molybdenum by Neutron Activation and Srafion NMRR Ion Exchange Resin Separation," Anal. Chem. 50, 294 (1978).

C30. R. A. Nadkarni and G. H. Morrison, "Determination of Silver in Rocks by Neutron Activation Analysis," Anal. Chem. 47, 2285 (1975).

C31. Perkin-Elmer Corporation, "Analytical Methods Using the HGA Graphite Furnace," Perkin-Elmer, Norwalk, Connecticut (1977).

C32. R. D. Ediger, "Atomic Absorption Analysis with the Graphite Furnace Using Matrix Modification," At. Absorption Newslett. 14, 127 (1975).

C33. J. W. Owens and E. S. Gladney, "Determination of Beryllium in Environmental Materials by Flameless Atomic Absorption Spectrometry," Atomic Absorption Newsletter 15, 95 (1976).

C34. J. W. Owens and E. S. Gladney, "Lithium Metaborate Fusion and the Determination of Trace Metals in Fly Ash by Flameless Atomic Absorption," Atomic Absorption Newsletter 15, 95 (1976).

C35. J. W. Owens and E. S. Gladney, "The Determination of Arsenic in Natural Waters by Flameless Atomic Absorption," Atomic Absorption Newsletter 15, 47 (1976).

C36. E. S. Gladney, "Matrix Modification for the Determination of Bi by Flameless Atomic Absorption," Atomic Absorption Newsietter 16, 114 (1977).

C37. E. S. Gladney and J. W. Owens, "Determination of $\mathrm{Hg}$ Using a Carrier-Free Combustion Separation and Flameless Atomic Absorption," Anal. Chim. Acta 90, 271 (1977). 
C38. E. S. Gladney, J. W. Owens, and D. R. Perrin, "The Determination of Mercury in Environmental Materials," Los Alamos Scientific Laboratory report LA-7865-MS, June 1979.

C.39. F. C. Smith and R. A. Wetzel, "Operation and Maintenance Manual for Dionex Model 10 and Model 14 Ion Chromatographs," Djonex Corp., Sunnyvale, California (1978).
C40. American Society for Testing and Materials, 1977 Annual Book of ASTM Standardo: Part 31: Water, ASTM, Philadelphia, Pennsylvaria (1977). 


\section{APPENDIX D}

\section{METHODS FOR DOSE CALCULATIONS}

\section{A. Airborne Tritium and Actinides}

Measured annual average concentrations in air, after subtracting background, are multiplied by standard breathing rates ${ }^{\mathrm{D} 1}$ to determine annual intake via inhalation. This intake is then multiplied by appropriate dose conversion factors ${ }^{D 2, D O}$ to convert intake into annual dose and 50 year dose commitments for various organs. Dose commitment factors for tritium include an increase by a factor of $\mathbf{1 . 5}$ over inhalation intake to account for skin absorption of tritium. Where appropriate, assumptions in references D2 and D3 have been changed to reflect the latest recommendations of the International Commission on Radiation Protection. ${ }^{\mathrm{D}}$

\section{B. Airborne Air Activation Products}

Nuclear reactions with air in the target areas at LAMPF cause the air activation products ${ }^{11} \mathrm{C},{ }^{12} \mathrm{~N}$, and ${ }^{15} \mathrm{O}$ to be formed. These isotopes are all positron emitters and have $20.4-\mathrm{min}, 10-\mathrm{min}$, and $122-\mathrm{s}$ halflives, respectively. Neutron reactions with air at the Omega West Reactor and LAMPF form "Ar $(1.8 \mathrm{~h}$ ralf-life). The concentrations of these isotopes $[\mathrm{X}(\mathrm{r}, \theta)]$ at the appropriate site boundary are calculated using the annual average meteorological dispersion coefficient (based Gaussian plume dispersion models)

$\mathrm{X}(\mathbf{r}, \theta) / \mathrm{Q}$

and the source term $Q$. The gamma dose rate in a semi-infinite cloud at time $k$ can be represented by the equation ${ }^{\mathrm{Ds}}$

$\gamma_{\infty}(\mathrm{r}, \theta, \mathrm{t})=0.25 \overline{\mathrm{E} \gamma} \mathrm{X}(\mathrm{r}, \theta, \mathrm{t})$, where

$\gamma_{\infty}(\mathrm{r}, \theta, \mathrm{t})=$ gamma dose rate $(\mathrm{rad} / \mathrm{s})$ at time $\mathrm{t}$ at a distance $r$ and angle $\theta$,

$\overline{\mathrm{E}} \gamma=$ average gamma energy per decay $(\mathrm{MeV})$, and

$\mathrm{X}(\mathrm{r}, \theta, \mathrm{t})=$ plume concentration in $\mathrm{Ci} / \mathrm{m}^{2}$ at time $\mathrm{t}$ at a distance $r$ and angle $\theta$.

Dose rate corrections for estimated plume size (if the cloud cannot be construed to be semi-infinite) is taken from standard graphical compilations. ${ }^{D s} \mathbf{E} \gamma$ is $1.02 \mathrm{MeV}$ for the positron emitters (two $0.511 \mathrm{MeV}$ gammas are produced in the positron annihilation process) and $1.29 \mathrm{MeV}$ for ${ }^{11} \mathrm{Ar}$. For maximum individual doses, a shielding factor because of structure shielding) of 0.7 is used. ${ }^{\text {Do }}$

\section{Man-rem Estimates}

Calculation of population dose est imates (in manrem) are based on measured data to the extent possible. For background racilation, average measured values for Los Alamos, White Rock, and regional stations were multiplied by the appropriate population number. Tritium average doses were calculated from average measured concentrations in Los Alamos and White Rock above background (as measured by regional stations). These doses were multiplied by appropriate population data. For ${ }^{41} \mathrm{Ar}$, ${ }^{11} \mathrm{C},{ }^{13} \mathrm{~N}$, and ${ }^{18} \mathrm{O}$, atmospheric dispersion models (see previous Section B) were used to calculate an average dose to the area in question which was then multiplied by appropriate population figures. Dispersion factors for TA-2 and TA-3 are given in Table D-I. Background radiation doses due to airline 
travel is based on the number of trips taken by Laboratory personnel. It was assumed that $85 \%$ of these trips were taken by Laboratory personnel residing in Los Alamos County and that nonLaboratory travel was $10 \%$ of the Laboratory trips. Average air time at altitude for each trip was estimated to be $4.5 \mathrm{~h}$ where the average dose rate is $0.22 \mathrm{mrem} / \mathrm{h}^{\mathrm{D}}{ }^{\mathrm{T}}$

TABLE D-I

\section{DISPERSION FACTORS $(x / Q)$ USED FOR POPULATION DOSE ESTIMATES}

\begin{tabular}{|c|c|c|}
\hline Source & Location & $\mathbf{x} / \mathbf{Q}\left(\mathbf{s} / \mathbf{m}^{3}\right)$ \\
\hline TA-2 & Los Alamos & $2 \times 10^{-8}$ \\
\hline TA-2 & White Rock & $7 \times 10^{-8}$ \\
\hline TA-53 & Los Alamos & $5 \times 10^{-7}$ \\
\hline TA-53 & White Rock & $1 \times 10^{-7}$ \\
\hline
\end{tabular}

\section{REFERENCES}

D1. International Commission on Radiation Protection, "Report of the Task Group on Reference Man," ICRP Report No. 23 (1975).

D2. G. R. Hoenes and J. K. Soldat, "Age-Specific Radiation Dose Commitment Factors for a
One-Year Chronic Intake," U.S. Nuclear Regulatory Commission Report NUREG-0172 (1977).

D3. J. P. Corley, et al., "A Guide for Environmental Radiological Surveillance at ERDA Installations, "U.S. Energy Research and Development Administration report ERDA-77-24, 1977.

D4. International Commission on Radiation Protection, "Limits for Intakes of Radionuclides by Workers," ICRP Report No. 30 (1979).

D5. D. H. Slade, Ed., "Meteorology and Atomic Energy 1967," U.S. AEC document TID-24190 (1968).

D6. "Calculation of Annual Doses to Man from Routine Releases of Reactor Effluents for the Purpose of Evaluating Compliance with 10 CFR Part 50, Appendix I," U.S. Nuclear Regulatory Commission Regulatory Guide 1.109 (1977).

D7. National Council on Radiation Protection and Measurements, "Natural Background Radiation in the United States," NCRP report No. 45 (November 1975). 
APPENDIX E

ENVIRONMENTAL DATA TABLES 
JABI.F: E-1

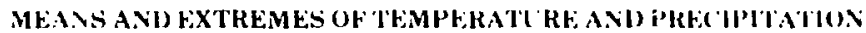
CLIMATOLOGICAL SIIIMMARY 195I-19TY"

\begin{tabular}{|c|c|c|c|c|c|c|c|c|c|c|c|c|c|c|c|c|c|c|c|c|}
\hline \multirow[b]{3}{*}{ Month } & \multicolumn{7}{|c|}{ Temperature $\left({ }^{\circ}\left({ }^{\circ}\right)\right.$} & \multicolumn{10}{|c|}{ Precipitation (mm) } & \multicolumn{3}{|c|}{ Mean Nio. of Days } \\
\hline & \multicolumn{3}{|c|}{ Means } & \multicolumn{4}{|c|}{ Extremes } & \multicolumn{5}{|c|}{ Kain } & \multicolumn{5}{|c|}{$\begin{array}{l}\text { Snuw/trozen } \\
\text { Precipitation }\end{array}$} & \multirow[b]{2}{*}{$\begin{array}{c}\text { Precip } \\
>2.5 \mathrm{~mm}\end{array}$} & \multirow{2}{*}{$\begin{array}{c}\text { Max } \\
\text { Temp } \\
>\$ 2^{\circ} \mathrm{C}\end{array}$} & \multirow{2}{*}{$\begin{array}{c}\text { Min } \\
\text { Temp } \\
<0^{\circ} \mathrm{C}\end{array}$} \\
\hline & Max & Min & $\begin{array}{l}\text { Mo. } \\
\text { Mean }\end{array}$ & High & Year & Low & Year & Mean & $\begin{array}{l}\text { Duily } \\
\text { Max }\end{array}$ & Year & $\begin{array}{l}\text { Mo. } \\
\text { Max }\end{array}$ & Year & Meen & $\begin{array}{l}\text { Daily } \\
\text { Max }\end{array}$ & Year & $\begin{array}{l}\text { Mo. } \\
\text { Max }\end{array}$ & Yeur & & & \\
\hline Jan & 4.2 & -7.5 & -1.7 & 17.8 & 1953 & -27.8 & $19 t i 3$ & 211.9 & 24.9 & 1951 & $\therefore i .8$ & 1952 & 240 & 250 & 1958 & $\pi 70$ & $19: 9$ & 2 & 11 & 30 \\
\hline Feh & 6.0 & -5.9 & 0.1 & 17.8 & 1957 & -27.2 & 1951 & 17.0 & 24.4 & $197 ;$ & 47.5 & 1964 & 190 & 270 & 1975 & 490 & $19 t i 4$ & 2 & 0.26 & \\
\hline March & 9.3 & -3.0 & 3.2 & 21.7 & 1971 & -16.7 & 1965 & 25.7 & 41.7 & $197: 1$ & 104.4 & 1973 & 250 & 360 & $197: 3$ & 910 & 1973 & 3 & 11 & 23 \\
\hline April & 14.2 & 1.0 & 7.6 & 25.0 & 1965 & -11.7 & $147: 3$ & 21.2 & 50.8 & 1975 & 82.0 & $197 \%$ & 120 & 510 & 1975 & 850 & 1958 & 2 & 1) & 13 \\
\hline Muy & 19.4 & 6.1 & 12.8 & 31.1 & 1951 & -4.4 & 1976 & 284 & 34.3 & 1952 & 88.9 & 1952 & 20 & 300 & 1978 & 410 & 1978 & 3 & 0 & 2 \\
\hline June & 25.3 & 11.3 & 18.3 & 33.9 & 1954 & 0.0 & 1975 & 29.5 & 29.7 & 1964 & 86.4 & 1960) & 0 & 0 & $\ldots$ & 0 & $\ldots$ & 3 & 0 & 0 \\
\hline July & 26.8 & 13.4 & 20.1 & 33.9 & 1957 & 7.2 & IGit & 8:3.2 & $t i 2.7$ & 1 Gion & 167.6 & 1964 & 11 & 0 & $\ldots$ & 0 & $\cdots$ & 8 & 1 & a \\
\hline Auk & 25.2 & 12.4 & 18.8 & 32.8 & 1977 & 6.1 & 1957 & 101.5 & 52.4 & $19: 1$ & 284.0 & 1952 & 1) & 0 & $\cdots$ & 0 & $\ldots$ & 9 & 0 & 0 \\
\hline Sept & 22.2 & 9.1 & 15.6 & 30.6 & 1956 & -333 & 1971 & 41.8 & 47.2 & $197: 3$ & 115.6 & 1975 & '? & 40 & 1971 & 40 & 1971 & 4 & $1)$ & 0 \\
\hline Oct & 16.7 & 3.8 & 10.3 & 26.1 & 1957 & $-y$ & $197 i$ & 391 & 52.3 & $19: \pi$ & 172.0 & 1957 & 40 & 230 & 1972 & 230 & 1959 & $: 3$ & 0 & 7 \\
\hline Nov & 9.3 & -2.7 & 3.3 & 18.9 & 1975 & -256 & 1976 & 24.6 & 45.0 & $19-8$ & 167.6 & 1978 & 130 & 300 & 1976 & 880 & $195 \pi$ & $\because$ & 0 & 22 \\
\hline Dec & 5.0 & -6.6 & -0.8 & 15.0 & 1965 & -25.0 & 19.8 & 24.9 & 40.6 & $190 \mathrm{~s}$ & 72.4 & 1965 & 300 & 560 & 1978 & 1050 & $196 \%$ & 2 & 0 & 30 \\
\hline
\end{tabular}

CLIMATOLOGICAL SUMMAKY 197!"

\begin{tabular}{|c|c|c|c|c|c|c|c|c|c|c|c|c|}
\hline \multirow[b]{3}{*}{ Month } & \multicolumn{5}{|c|}{ Temperature $\left({ }^{\circ}()^{\prime}\right)$} & \multicolumn{4}{|c|}{ Precipitation (mnı) } & & & \\
\hline & \multicolumn{3}{|c|}{ Means } & \multicolumn{2}{|c|}{ Extremes } & \multicolumn{2}{|c|}{ Rain } & \multicolumn{2}{|c|}{$\begin{array}{l}\text { Snow/Frozen } \\
\text { Precipitation } \\
\end{array}$} & \multicolumn{3}{|c|}{ No. of Days } \\
\hline & $\underline{\operatorname{Max}}$ & Min & $\begin{array}{c}\text { Mo. } \\
\text { Mean }\end{array}$ & $\underline{\text { High }}$ & Low & Total & $\begin{array}{l}\text { Daily } \\
\text { Max }\end{array}$ & Total & $\begin{array}{l}\text { Daily } \\
\text { Max }\end{array}$ & $\begin{array}{c}\text { Precip } \\
22.5 \mathrm{~mm} \\
\end{array}$ & $\begin{array}{c}\text { Max } \\
\text { Temp } \\
>32^{\circ} \mathrm{C}\end{array}$ & $\begin{array}{c}\text { Min } \\
\text { Temp } \\
<\theta^{\circ} \mathrm{C} \\
\end{array}$ \\
\hline Jan & 0.5 & -11.0 & $-5,3$ & 5.6 & -22.8 & 71.4 & 23.1 & 770 & 250 & 2 & 0 & 31 \\
\hline Feb & 5.5 & -6.8 & -0.7 & 15.6 & -15.6 & 3.6 & 2.5 & 30 & 30 & 1 & 0 & 28 \\
\hline March & 9.3 & -2.8 & 3.3 & 15.6 & -8.9 & 32.3 & 11.2 & 190 & 110 & 6 & 0 & 30 \\
\hline April & 14.7 & 1.2 & 8.0 & 21.7 & -6.7 & 10.9 & 4.8 & 0 & 0 & 1 & 0 & 12 \\
\hline May & 17.7 & 4.3 & 11.0 & 23.9 & -2.2 & 78.7 & 18.0 & 0 & 0 & 3 & 0 & 6 \\
\hline June & 24.1 & 9.4 & 16.8 & 31.1 & 0.0 & 53.6 & 17.3 & 0 & 0 & 4 & 0 & 1 \\
\hline July & 27.8 & 12.7 & 20.3 & 32.2 & 7.2 & 19.8 & 8.4 & 0 & 0 & 5 & 2 & 0 \\
\hline Aug & 25.5 & 10.9 & 18.2 & 31.1 & 7.8 & 59.2 & 32.5 & 0 & 0 & 6 & 0 & 0 \\
\hline Sept & 24.3 & 9.3 & 16.8 & 30.0 & 3.3 & 20.8 & 10.4 & 0 & 0 & 3 & 0 & 0 \\
\hline Oct & 19.3 & 5.1 & 12.2 & 25.6 & -3.9 & 15.0 & 6.1 & 100 & 100 & 4 & 0 & 5 \\
\hline Nov & 6.t & -5.4 & 0.5 & 13.3 & -13.3 & 12.2 & 4.3 & 20 & 10 & 7 & 0 & 26 \\
\hline Dec & 8.3 & -5.5 & 1.4 & 15.0 & -11.1 & 9.1 & 5.8 & $2 ; 30$ & 180 & 4 & 0 & 31 \\
\hline
\end{tabular}

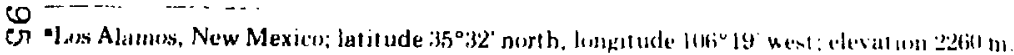

Indurles liquid water equivalent ol trozen precipitation. 
TABLF E-II

ANNUAL THERMOLUMINESCENT DOSIMETEK MLASL:RLMHNTS

\begin{tabular}{|c|c|c|c|c|c|c|c|c|c|}
\hline \multirow[b]{2}{*}{ Station Location } & \multirow[b]{2}{*}{ Coordinates } & \multicolumn{3}{|c|}{ Annual Dose } & \multirow[b]{2}{*}{ Stution Location } & \multirow[b]{2}{*}{ Coordinates } & \multicolumn{3}{|c|}{ Annual Dose } \\
\hline & & $\begin{array}{c}\text { Dose } \\
\text { (mrem) }\end{array}$ & $\begin{array}{l}95 \% \text { Conf } \\
\text { Interval } \\
\text { (mem) }\end{array}$ & $\begin{array}{l}95 \% \text { Conf } \\
\text { Interval } \\
\text { (per cent) }\end{array}$ & & & $\begin{array}{c}\text { Dose } \\
\text { (mrem) }\end{array}$ & $\begin{array}{l}95 \% \text { Conf } \\
\text { Interval } \\
\text { (nirem) } \\
\end{array}$ & $\begin{array}{l}95 \% \text { Conf } \\
\text { Interval } \\
\text { (per cent) }\end{array}$ \\
\hline Regional Stations & $(28-44 \mathrm{~km})$ & \multicolumn{3}{|c|}{ Uncontrolled Areas } & Onsite Stations & & \multicolumn{3}{|c|}{ Controlied Areus } \\
\hline Españula & $\cdots$ & 97.3 & 3.3 & 3.4 & TA-21 & NuOUE10 & 112.4 & 3.3 & 3.0 \\
\hline Pojoaque & $\cdots$ & 94.2 & 3.4 & 3.6 & Sitate Hwy 4 & No70 E350 & 186.5 & 3.5 & 1.9 \\
\hline \multirow[t]{3}{*}{ Santa Fe } & $\cdots$ & 84.1 & 3.3 & 4.0 & Well PM-1 & No:30 Fi310 & 133.2 & 3.4 & 2.5 \\
\hline & Retional Average & 91.9 & & & 'TA-53 & No60 E 190 & 150.1 & 3.4 & 2.3 \\
\hline & & & & & TA.2 & Noso E110 & 123.7 & 3.8 & 3.1 \\
\hline Perimgter Stations & $(0-4 \mathbf{k m})$ & \multirow{2}{*}{\multicolumn{3}{|c|}{ Uncontrolled Areas }} & TA-2 & No80 E120 & 167.5 & 3.4 & 2.11 \\
\hline & & & & & TA-6 & No60 W050 & 129.1 & 3.6 & 2.8 \\
\hline Barranca School & N180 E130 & 124.5 & & & TA-16 & s030W080 & 125.1 & 3.4 & 3.7 \\
\hline Cumbres Schwol & N150 E090 & 120.2 & 5.9 & 4.7 & TA.49 & 5100 E040 & 108.7 & 3.4 & 3.1 \\
\hline Arkansas Avenue & Niz Fo? & 120.6 & 3.8 & 3.2 & Buoster i? & Sion E300 & 122.3 & 3.3 & 2.7 \\
\hline 48th Street & N170 E020 & 144.8 & 3.4 & 2.3 & TA-18 & So30 E190 & 252.0 & 3.7 & 1.5 \\
\hline $\begin{array}{l}\text { 48th street } \\
\text { LA Airport }\end{array}$ & N110 E000 & 144.0 & 3.4 & 2.4 & TA-35 & N040E110 & 132.9 & 3.4 & 2.5 \\
\hline Bayo Canyon S.T.P. & N110 E160 & 129.6 & 3.3 & 2.6 & TA-35 & No30 Ė110 & 123.8 & 3.4 & 2.7 \\
\hline $\begin{array}{l}\text { Bayo Canyon S.T.P. } \\
\text { Handelier Lookout }\end{array}$ & N110 E260 & 147.3 & 3.9 & 2.6 & TA-3 & No60 E010 & 153.1 & 3.4 & $\because 2.2$ \\
\hline $\begin{array}{l}\text { Bandelier Lookout } \\
\text { Pajarito Acres }\end{array}$ & S270 E200 & 123.0 & 3.3 & 2.7 & TA $\cdot 3$ & N050 E040 & 128.8 & 3.3 & 2.6 \\
\hline $\begin{array}{l}\text { Pajarito Acres } \\
\text { White Rock S.T.P. }\end{array}$ & S210 E370 & 111.6 & 3.3 & 3.0 & ТА.54 & S080 E260 & 153.8 & 3.4 & 2.2 \\
\hline $\begin{array}{l}\text { Pejarito Ski Area } \\
\text { Peje }\end{array}$ & $\begin{array}{l}\text { S090 E430 } \\
\text { IN130 W180 }\end{array}$ & $\begin{array}{l}118.6 \\
114.2\end{array}$ & 3.3 & 2.8 & & Onsite Average & 143.9 & & \\
\hline Gulf Station & N100 E100 & $\begin{array}{l}114.2 \\
130.8\end{array}$ & $\begin{array}{l}3.3 \\
3.4\end{array}$ & 2.6 & & & & & \\
\hline \multirow[t]{2}{*}{ Royal Crest } & N080 E08r & 129.2 & 3.8 & 3.0 & & & & & \\
\hline & Perimetor Average & 128.2 & & & & & & & \\
\hline
\end{tabular}


TABLE E-III

LOCATION OF AIR SAMPLING STATIONS

\begin{tabular}{|c|c|c|}
\hline Station & $\begin{array}{c}\text { Latitude } \\
\text { or } \\
\text { N-S Coord }\end{array}$ & $\begin{array}{c}\text { Longitude } \\
\text { or } \\
\text { E-W Coord }\end{array}$ \\
\hline Regional (28-44 km) & & \\
\hline $\begin{array}{l}\text { 1. Española } \\
\text { 2. Pojoaque } \\
\text { 3. Santa Fe }\end{array}$ & $\begin{array}{l}36^{\circ} 00^{\prime} \\
35^{\circ} 52^{\prime} \\
35^{\circ} 40^{\prime}\end{array}$ & $\begin{array}{l}106^{\circ} 06^{\prime} \\
106^{\circ} 02^{\prime} \\
106^{\circ} 56^{\prime}\end{array}$ \\
\hline Perimeter (0-4 km) & & \\
\hline $\begin{array}{l}\text { 4. Barranca School } \\
\text { 5. Arkansas Avenue } \\
\text { 6. Cumbres School } \\
\text { 7. 48th Street } \\
\text { 8. LA Airport } \\
\text { 9. Bayo STP } \\
\text { 10. Gulf Station } \\
\text { 11. Royal Crest } \\
\text { 12. White Rock } \\
\text { 13. Pajarito Acres } \\
\text { 14. Bandelier }\end{array}$ & $\begin{array}{l}\text { N180 } \\
\text { N170 } \\
\text { N150 } \\
\text { N110 } \\
\text { N110 } \\
\text { N110 } \\
\text { N100 } \\
\text { N080 } \\
\text { S090 } \\
\text { S210 } \\
\text { S270 }\end{array}$ & $\begin{array}{l}\text { E130 } \\
\text { E020 } \\
\text { E090 } \\
\text { E000 } \\
\text { E260 } \\
\text { E100 } \\
\text { E080 } \\
\text { E430 } \\
\text { E370 } \\
\text { E200 }\end{array}$ \\
\hline Onsite & & \\
\hline $\begin{array}{l}\text { 15. TA-21 } \\
\text { 16. TA-6 } \\
\text { 17. TA-53 (LAMPF) } \\
\text { 18. Well PM-1 } \\
\text { 19. TA-52 } \\
\text { 20. TA-16 } \\
\text { 21. Booster P-2 } \\
\text { 22. TA-54 } \\
\text { 23. TA-49 } \\
\text { 24. TA-33 } \\
\text { 25. TA-39 }\end{array}$ & $\begin{array}{l}\text { N090 } \\
\text { N060 } \\
\text { N060 } \\
\text { N030 } \\
\text { N020 } \\
\text { S030 } \\
\text { S030 } \\
\text { S080 } \\
\text { S100 } \\
\text { S250 } \\
\text { S210 }\end{array}$ & $\begin{array}{l}\text { E170 } \\
\text { W050 } \\
\text { E190 } \\
\text { E310 } \\
\text { E170 } \\
\text { W080 } \\
\text { E190 } \\
\text { E260 } \\
\text { E040 } \\
\text { E230 } \\
\text { E210 }\end{array}$ \\
\hline
\end{tabular}


TABLE E-IV

\section{REGIONAL AVERAGE BACKGROUND ATMOSPHERIC RADIOACTIVITY CONCENTRATIONS}

\begin{tabular}{|c|c|c|c|}
\hline \multirow{2}{*}{$\begin{array}{l}\text { Radioactive } \\
\text { Constituent }\end{array}$} & \multicolumn{3}{|c|}{ Activity-pCi/m $\left(10^{-18} \mu \mathrm{Ci} / \mathrm{m} \ell\right)$} \\
\hline & EPA" & LASL $^{\mathbf{b}}$ & $\mathbf{C G}^{\mathbf{c}}$ \\
\hline Gross alphad & Not reported & $1.4 \pm 0.5$ & 60 \\
\hline Gross beta & 83 & $89 \pm 126$ & $1 \times 10^{8}$ \\
\hline${ }^{241} \mathrm{Am}$ & Not reported & $0.0024 \pm 0.0038$ & $2 \times 10^{2}$ \\
\hline${ }^{250} \mathrm{Pu}$ & $0.0018 \pm 0.0018$ & $0.013 \pm 0.014$ & 70 \\
\hline${ }^{230} \mathrm{Pu}$ & $0.0199 \pm 0.0100$ & $0.0020 \pm 0.0035$ & 60 \\
\hline Tritium & Not reported & $9200 . \pm 9800$ & $2 \times 10^{\circ}$ \\
\hline Total uranium & $\begin{array}{c}0.0408 \pm 0.0300 \\
(120 \pm 88)^{t}\end{array}$ & $\begin{aligned} 0.032 & \pm 0.030 \\
(98 & \pm 94)^{r}\end{aligned}$ & $7 \times 10^{4}$ \\
\hline
\end{tabular}

- "Radiological Quality of the Environment," (EPA-520/1-76-(10)). USEPA. Office of Radiation Programs, Washington, DC (1976).

'Annual averages for 1973-1979.

'Concentration Guide for uncontrolled areas.

¿Gross alpha activity compared to CG for ${ }^{200} \mathrm{Pu}$.

'(iross beta activity compared to CG for ${ }^{13 !}$.

$\mathrm{pg} / \mathrm{m}^{*}$. 
TABLE F.-N

ANNLAL ATMOSPHERIC LONG -LIVFI)

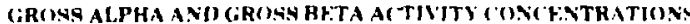

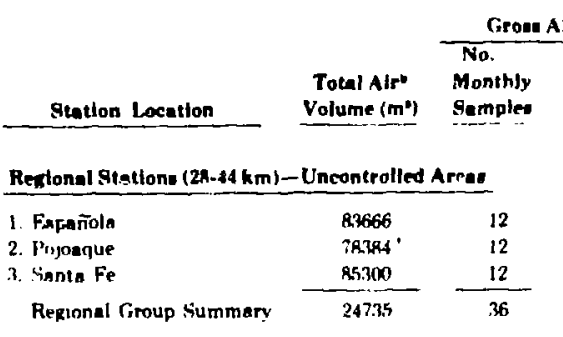

Grome Alphe Concentretlonn $-\pi V m^{\prime}\left(100^{\prime \prime} \mu(V m l)\right.$

No.

Perimeter Stations (0-4 km)-Uncontrolled Areese

\begin{tabular}{|c|c|c|}
\hline 4. Parranca School & 88754 & 12 \\
\hline 5. Arkannan Avenue & 79.354 & 12 \\
\hline 6. Cumbren Schrnl & 8.3701 & 12 \\
\hline 7. Ath Street & 84024 & 12 \\
\hline 8. 1.A Airport & 94I:3R & 12 \\
\hline 9. Bayo STI & 93932 & 12 \\
\hline 10. Ciulf Statinn & 82467 & 12 \\
\hline 11. Ruyal Crest & 81215 & 12 \\
\hline 12. White Rock & 83997 & 12 \\
\hline 13. Pajarito Acres & P46:2 & 12 \\
\hline 14. Handelier & 79773 & 12 \\
\hline Perimeter Giroup Summary & 935993 & 1.32 \\
\hline
\end{tabular}

\begin{tabular}{l}
1 \\
0 \\
0 \\
0 \\
0 \\
0 \\
0 \\
3 \\
0 \\
0 \\
0 \\
\hline 1
\end{tabular}

\begin{tabular}{llll}
$5.0 \pm 2.2$ & $0.2 \pm 0.1$ & $2.5 \pm 3.2$ & 4.1 \\
$0.9 \pm 30$ & $10 \pm 0.4$ & $3.1 \pm 3.4$ & 5.2 \\
$7.4 \pm 3.2$ & $01 \pm 0.3$ & $3.2 \pm 3.5$ & 5.3 \\
$4.1 \pm 1.8$ & $05 \pm 0.2$ & $1.7 \pm 2.1$ & 2.8 \\
$4.1 \pm 18$ & $0.4 \pm 0.2$ & $1.9 \pm 2.4$ & 3.2 \\
$5.3 \pm 2.4$ & $0.1 \pm 2.4$ & $2.0 \pm 2.8$ & 3.3 \\
$1.9 \pm 22$ & $0.7 \pm 0.3$ & $2.1 \pm 2.6$ & 3.4 \\
$3.7 \pm 1.6$ & $011 \pm 0.1$ & $1.6 \pm 2.4$ & 2.6 \\
$2.8 \pm 12$ & $11 \pm 0.2$ & $1.4 \pm 1.3$ & 2.3 \\
$6.5 \pm 2.4$ & $06 \pm 0.3$ & $2.6 \pm 2.7$ & 4.3 \\
$6.0 \pm 2.8$ & $11.5 \pm 0.3$ & $23 \pm 3.9$ & 1.4 \\
\hline $7.4 \pm 3.2$ & $010 \pm 0.1$ & $22 \pm 2.8$ & 3.7
\end{tabular}
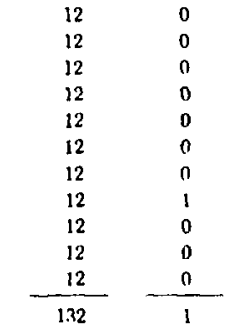$$
62 \pm 18 \quad 2.0 \pm 0.3 \quad 31 \pm 31 \quad 0.03
$$$$
\begin{array}{llll}
52 \pm 14 & 19 \pm 4 & 34 \pm 18 & 0.03
\end{array}
$$$$
55 \pm 14 \quad 11 \pm 3 \quad 31 \pm 23 \quad 0.03
$$$$
42 \pm 10 \quad 13 \pm 3 \quad 28 \pm 17 \quad 002
$$$$
35 \pm 8 \quad 17 \pm 4 \quad 25 \pm 13 \quad 0.02
$$$$
45 \pm 12 \quad 11 \pm 3 \quad 20 \pm 23 \quad 0.02
$$$$
5.5 \pm 14 \quad 4.2 \pm 10 \quad 28 \pm 28 \quad 0.02
$$$$
48 \pm 12 \quad 5.0 \pm 1.2 \quad 17 \pm 26 \quad 0.01
$$$$
35 \pm 10 \quad 18 \pm 4 \quad 23 \pm 10 \quad 0.02
$$$$
59 \pm 16 \quad 24 \pm 6 \quad 33 \pm 19 \quad 0.03
$$$$
\stackrel{60 \pm 16 \quad 18 \pm \pm \quad 2 B \pm 26}{-0.02}
$$

Onelte Stationa-Controlled Areat

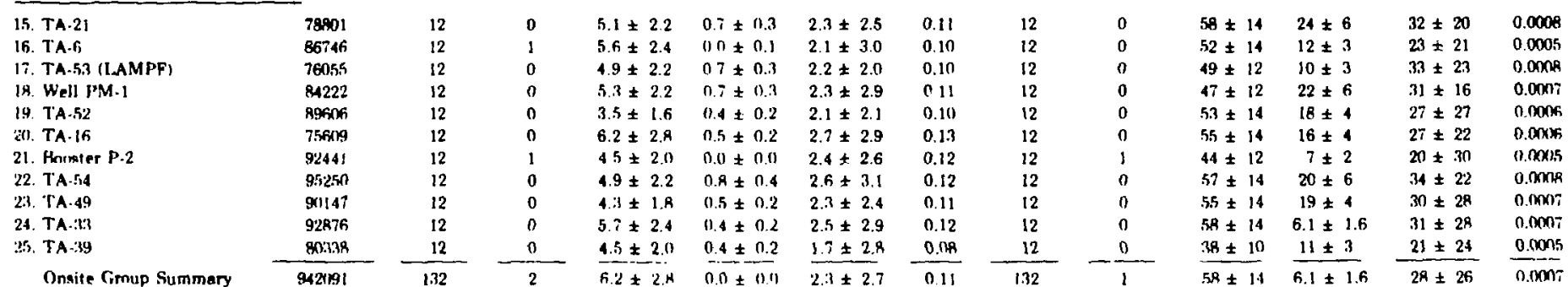

The riters are held 7.10 days hefore analyaia in allew naturally-urcurring radin-thuren dnughters in reach exulitibrium with their long-lived parents

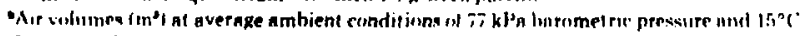

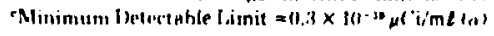

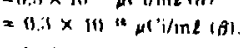

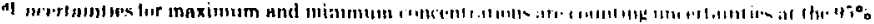

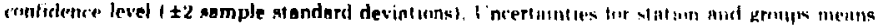
nir +2 standard deviations.

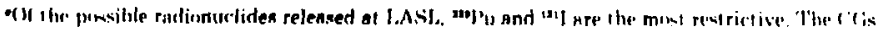

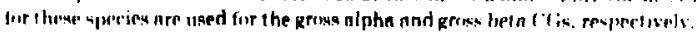

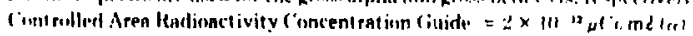

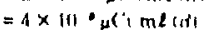

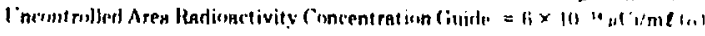

$$
=1 \times 118101,1+1,1,31
$$


TAHНЕ: E-VI

ANNUAL ATMOSPHERIC TRITIATED WATER VAPOH C'UNC 'HNTHATUNA

\begin{tabular}{|c|c|c|c|c|c|c|c|}
\hline \multirow[b]{2}{*}{ Station Location } & \multirow[b]{2}{*}{$\begin{array}{c}\begin{array}{c}\text { Totel Air } \\
\text { Volume }\left(m^{*}\right)^{\circ}\end{array} \\
\end{array}$} & \multirow{2}{*}{$\begin{array}{c}\text { No. } \\
\text { Momthy } \\
\text { Semples }\end{array}$} & \multirow{2}{*}{$\begin{array}{c}\text { Ne. } \\
\text { Bamples } \\
\text { <MDL }\end{array}$} & \multicolumn{4}{|c|}{ Concentration: $-\mathrm{p}\left(\mathrm{i} / \mathrm{m}^{*}(10 \mathrm{~s} \mu(\mathrm{i} / \mathrm{ml})\right.$} \\
\hline & & & & Max & Min" & Mienn' & $\begin{array}{c}\text { Mean an } \\
\% \text { CGe }\end{array}$ \\
\hline \multicolumn{8}{|c|}{ Regional thetions $(28.14 \mathrm{~km})-$-Uncontrolled Areas } \\
\hline 1. Española & 123 & 12 & 3 & $20 \pm 10$ & $-1.4 \pm 1.0$ & $3.7 \pm 13$ & 0.001 \\
\hline 2. Hijoaque & 114 & 12 & 5 & $9 \pm 3$ & $-0.4 \pm 0.8$ & $1.9 \pm 5.3$ & 0.001 \\
\hline 3. Santa Fe & 122 & 12 & 2 & $9 \pm 3$ & $-0.3 \pm 0.8$ & $2.4 \pm 5.1$ & 0.001 \\
\hline Regional Group Summary & 358 & 36 & 10 & 21) \pm 10 & $-1.4 \pm 1$ & $2.7 \pm 8.7$ & 0.001 \\
\hline \multicolumn{8}{|c|}{ Perimeter Stations $(0-1 \mathrm{~km})-U$-Ucontrolled Areas } \\
\hline 4. Harrenca Schoul & 118 & 12 & 3 & $13 \pm 4$ & $0.8 \pm 1.0$ & $2.7 \pm 4.2$ & 0.001 \\
\hline 5. Arkansas Ave & 113 & 12 & 5 & $+11 \pm 18$ & $0.2 \pm 0.6$ & $2.7 \pm 7.1$ & 0.001 \\
\hline 6. Cumbres Schoul & 123 & 12 & 1 & $24 \pm 8$ & $0.2 \pm 0.8$ & $4.7 \pm 13$ & 0.002 \\
\hline 7. 48 th Street & 123 & 12 & 2 & $17 \pm 6$ & $0.7 \pm 1.0$ & $4.4 \pm 10$ & 0.002 \\
\hline 8. LA Airport & 120 & 12 & 2 & $65 \pm 22$ & $0.8 \pm 0.8$ & $9 \pm 34$ & 0.004 \\
\hline 9. Bayo S'J' & 123 & 12 & 4 & $13 \pm 4$ & $0.1 \pm 0.6$ & $3.5 \pm 8.0$ & 0.001 \\
\hline 10. Gulf Station & 123 & 12 & 1 & $15 \pm 6$ & $1.0 \pm 0.8$ & $4.1 \pm 7.5$ & 0.002 \\
\hline 11. Huyal Crent & 117 & 12 & 0 & $16 \pm 6$ & $1.3 \pm 0.6$ & $6.7 \pm 9.9$ & 0.003 \\
\hline 12. White Hock & 122 & 12 & 2 & $10 \pm 3$ & $0.4 \pm 0.6$ & $4.1 \pm 5.4$ & 0.002 \\
\hline 13. Pajarito Acres & 122 & 12 & 2 & $48 \pm 16$ & $0.6 \pm 0.6$ & $6.6 \pm 25$ & 0.003 \\
\hline 14. Handelier & 122 & 12 & 1 & $19 \pm 6$ & $0.4 \pm 0.2$ & $6.2 \pm 12$ & 0.003 \\
\hline Perimeter Group Summary & 1326 & 132 & 23 & $65 \pm 22$ & $01+0.6$ & $4.9 \pm 15$ & 0.002 \\
\hline \multicolumn{8}{|c|}{ Onuite Stetions-Controlled Area } \\
\hline 15. $\mid \mathrm{I} A \cdot 21$ & 120 & 12 & 1 & $11 \pm 3$ & $1.0 \pm 1.0$ & $3.8 \pm 6.1$ & $0.000 \mathrm{i}$ \\
\hline 16. TA.6 & 122 & 12 & 4 & $7 \pm 2$ & $-0.3 \pm 0.8$ & $2.8 \pm 4.5$ & 0.0001 \\
\hline 17. TA-5.3 (IAAMPF) & 122 & 12 & 1 & $16 \pm 6$ & $0.6 \pm 0.8$ & $4.3 \pm 8.6$ & 0.0001 \\
\hline 18. Well PM-1 & 122 & 12 & 3 & $9 \pm 3$ & $-3.0 \pm 1.2$ & $3.6 \pm 7.7$ & $0.00 \times) 1$ \\
\hline 19. TA-52 & 122 & 12 & $\mathbf{0}$ & $134 \pm \pm 40$ & $1.8 \pm 1.0$ & $15 \pm 64$ & $0.000: 3$ \\
\hline 20. TA-16 & 117 & 12 & 6 & $5 \pm 2$ & $-0.1 \pm 0.6$ & $2.2 \pm 3.9$ & $0.000(1)$ \\
\hline 21. Broster P.2 & 119 & 12 & 1 & BaI \pm 20 & $0.9 \pm 0.8$ & $8.1 \pm 31$ & 0.0002 \\
\hline 22. TA.54 & 123 & 12 & $\mathbf{0}$ & liw \pm 40 & $5.9 \pm 2.2$ & $35 \pm 74$ & $0.00 \times n$ \\
\hline 23. TA-49 & 119 & 12 & 4 & $\$ 11 \pm 12$ & $-0.4 \pm 0.6$ & $5.4 \pm 21$ & 0.0001 \\
\hline 24. TA-33 & 110 & 11 & $\mathbf{0}$ & $73 \pm \pm 24$ & $3.2 \pm 1.4$ & $40 \pm 42$ & $0.00 u s$ \\
\hline 25. T'A.39 & 119 & 12 & 1 & $3 * \pm 12$ & $3.6 \pm 1.6$ & $16 \pm 21$ & $0.0000: 1$ \\
\hline On-Site Gruup Summary & 1315 & 131 & 19 & $1: 10 \pm 40$ & $-3.0 \pm 1.2$ & $12 \pm 42$ & 0.0002 \\
\hline
\end{tabular}

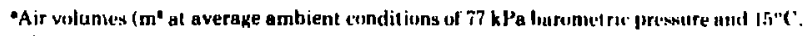

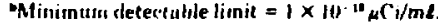

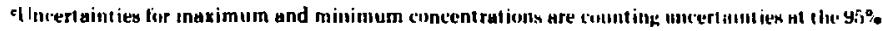

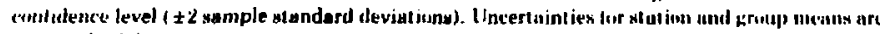
\pm 2 itundard deviations.

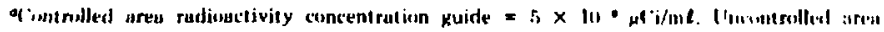
raflubetivily concent cation $x$ uide $=2 \times 10^{+} \mu(\mathrm{Si} / \mathrm{in} \ell$. 
TABLF, E,-VII

ANNIJAL ATMOSPHERIC "Pu and MPU CONCENTRATIONS

\begin{tabular}{|c|c|c|c|c|c|c|c|c|c|c|c|c|c|}
\hline \multirow[b]{2}{*}{ Station Location } & \multirow[b]{2}{*}{$\begin{array}{c}\text { Total Air } \\
\text { Volume }\left(m^{\prime}\right)^{*}\end{array}$} & \multicolumn{6}{|c|}{${ }^{m+P u} \rightarrow \mathrm{Cl}^{\prime} / \mathrm{m}^{\prime}\left(10^{-10} \mu \mathrm{Cl} / \mathrm{m} l^{*}\right)$} & \multicolumn{6}{|c|}{$m \mathrm{Pu}-\mathrm{Cl} \mathrm{C} / \mathrm{m}^{\prime}\left(10^{-10} \mu \mathrm{Cl} / \mathrm{ml}^{\circ}\right)$} \\
\hline & & $\begin{array}{c}\text { Number of } \\
\text { Samples }\end{array}$ & $\begin{array}{c}\text { No } \\
<\mathrm{MDL}: \\
\end{array}$ & Max & Minr & Meane & $\begin{array}{l}\text { Mean as } \\
\% \text { CG }\end{array}$ & $\begin{array}{l}\text { Number of } \\
\text { Samples }\end{array}$ & $\begin{array}{c}\text { No } \\
\leq \mathrm{MPD} \mathrm{b}^{\mathrm{b}} \\
\end{array}$ & Max & Min $^{c}$ & Mesn' & $\begin{array}{c}\operatorname{Mean} \text { as } \\
7 \mathrm{C} \mathbf{G}^{\circ}\end{array}$ \\
\hline \multicolumn{14}{|c|}{ Regional Stationr (28-44 km)--Uncontrolled Areas } \\
\hline 1. Fspar̃ola & 85152 & 5 & 5 & $15 \pm 2.2$ & $-5.2 \pm 4.7$ & $-1.8 \pm 3.4$ & $n .0$ & 5 & 3 & $25 \pm 4.8$ & $-0.5 \pm 1.5$ & $8.4 \pm 26$ & D) 14 \\
\hline 2. Pojoaque & 87954 & 5 & 5 & $-2.7 \pm 2.2$ & $-5.7 \pm 45$ & $-3.8 \pm 3.7$ & 0.0 & 5 & 3 & $12 \pm 49$ & $-0.9 \pm 1.8$ & $3.3 \pm 5.3$ & 0.606 \\
\hline 3. Santa Fe & 93752 & 5 & 5 & $-1.5 \pm 1 . t$ & $-62 \pm 4.5$ & $-2.1 \pm 1$ & 0.0 & 5 & 2 & $9.1 \pm 53$ & $1.3 \pm 1.8$ & $3.6 \pm 2.2$ & octurs \\
\hline Regional Group Summary & 26GR5B & 15 & 15 & $1.5 \pm 22$ & $-6.2 \pm 4.5$ & $-2.6 \pm 3.2$ & 0.0 & 15 & B & $25 \pm 4.8$ & $-0.9 \pm 1.8$ & $5 \pm 16$ & $0 .(x) 8$ \\
\hline
\end{tabular}

Perimeter Stations $(0.4 \mathrm{~km})-$ Uneontr "led Area:

\begin{tabular}{|c|c|c|c|}
\hline 4. Barranca Schoml & 83759 & 5 & 5 \\
\hline 5. Arkanans Avenue & 77628 & 5 & 5 \\
\hline 6. Cumbires School & B702? & 5 & 5 \\
\hline 7. 48th Street & 92241 & 5 & 5 \\
\hline B. IA Airport & 101124 & 5 & 5 \\
\hline 9. Bayo STP & 98239 & 5 & 5 \\
\hline 10. Gulf Station & 78747 & 5 & 5 \\
\hline 11. Royal Crest & 75755 & 5 & 5 \\
\hline 12. White Rnck & 88259 & 5 & 5 \\
\hline 13. Pajurito Acres & 83397 & 5 & 5 \\
\hline 14. Randelier & 77173 & 5 & 5 \\
\hline Perimeter Group Summary & 943349 & 55 & \\
\hline
\end{tabular}

\begin{tabular}{rccccc}
$-1.4 \pm 1.8$ & $-12 \pm 7.8$ & $-3.4 \pm 3.1$ & 0.0 & 5 & 3 \\
$-1.8 \pm 2.1$ & $-6.1 \pm 6.2$ & $-2.7 \pm 1.5$ & 0.0 & 5 & 2 \\
$1.6 \pm 2.9$ & $-6.2 \pm 4.5$ & $-0.9 \pm 3.5$ & 0.0 & 5 & 1 \\
$0.3 \pm 21$ & $-1.4 \pm 15$ & $-2.4 \pm 6.7$ & 0.0 & 5 & 1 \\
$-1.3 \pm 4.7$ & $-3.9 \pm 3.1$ & $-2 \pm 1.7$ & 0.0 & 5 & 1 \\
$-2 \pm 1.3$ & $-4.4 \pm 3.9$ & $-2.5 \pm 1.3$ & 0.0 & 5 & 1 \\
$-1.1 \pm 1.9$ & $-7.1 \pm 4.5$ & $-2.8 \pm 2$ & 0.0 & 5 & 1 \\
$-0.3 \pm 3.2$ & $-5.3 \pm 5.1$ & $-2.1 \pm 24$ & 0.0 & 5 & 2 \\
$-1.5 \pm 1.8$ & $-4.4 \pm 2.9$ & $-2.5 \pm 1.2$ & 0.0 & 5 & 2 \\
$-0.2 \pm 2.3$ & $-6.7 \pm 4.5$ & $-1.8 \pm 2$ & 0.0 & 5 & 1 \\
$-1.9 \pm 1.9$ & $-4.6 \pm 5$ & $-2.6 \pm 1.2$ & 0.0 & & $\frac{i}{16}$ \\
\hline $1.6 \pm 2.9$ & $-14 \pm 1$. & $-2.3 \pm 2.9$ & 0.0 & 55 &
\end{tabular}

\begin{tabular}{lrll}
$17 \pm 3.9$ & $-7 \pm 25$ & $6.6 \pm 22$ & 0.011 \\
$20 \pm 6.9$ & $-1.2 \pm 1.3$ & $5.4 \pm 9.2$ & 0.009 \\
$8 . \pm 11$ & $-1.7 \pm 1.5$ & $25 \pm 91$ & 0.041 \\
$33 \pm 6.7$ & $3.3 \pm 2.2$ & $13 \pm 28$ & 0.022 \\
$14 \pm 4.5$ & $1.4 \pm 4.5$ & $4.8 \pm 5$ & 0.008 \\
$11 \pm 5.1$ & $-0.2 \pm 1.3$ & $4.8 \pm 6.3$ & 0.008 \\
$12 \pm 3.3$ & $-2.6 \pm 2.9$ & $8.4 \pm 13$ & 0.014 \\
$21 \pm 6.6$ & $-0.3 \pm 1.8$ & $4.4 \pm 6.6$ & 0.197 \\
$23 \pm 6.6$ & $0.1 \pm 1.5$ & $1.2 \pm 6.5$ & 0.007 \\
$16 \pm 5.8$ & $0.5 \pm 2.1$ & $6.2 \pm 9.2$ & 0.010 \\
$14 \pm 5.1$ & $-0.6 \pm 1.7$ & $6 \pm 10$ & 0.010 \\
\hline $83 \pm 11$ & $-7 \pm 25$ & $8.1 \pm 30$ & 0.013
\end{tabular}

Onite Stationa-Controlled Arese

\begin{tabular}{|c|c|c|c|c|c|c|c|c|c|c|c|c|c|}
\hline 15. TA-21 & 85195 & 5 & 5 & $-1.5 \pm 2.4$ & $-6.5 \pm 47$ & $-2.5 \pm 0.8$ & 0.0 & 5 & 2 & $17 \pm 5.6$ & $0.0 \pm 1.7$ & $6.1 \pm 10$ & 0,00003 \\
\hline 16. TA.6 & 93917 & 5 & 5 & $-1.3 \pm 1.6$ & $-5.8 \pm 4.2$ & $-2.4 \pm 1.1$ & 0.0 & 5 & 3 & $8.3 \pm 3.9$ & $-1.8 \pm 2.5$ & $3.3 \pm 7.8$ & 0.0072 \\
\hline 17. TA.53 (LAMPF) & R923? & 5 & 5 & $-1.4 \pm 1.7$ & $-8 \pm 5$ & $-2.3 \pm 2$ & 0.0 & 5 & 1 & $12 \pm 5$ & $-0.2 \pm 1 . \mathrm{B}$ & $4.9 \pm 6.4$ & $0 . \mathrm{mm}_{2}$ \\
\hline 18. Well PM-1 & 91165 & 5 & 5 & $-2 \pm 1.8$ & $-5.9 \pm 4.9$ & $-2.8 \pm 1,6$ & 0.0 & 5 & $\mathbf{I}$ & $11 \pm 4.1$ & $0.2 \pm 2.1$ & $5.3 \pm 6.3$ & 0.0003 \\
\hline 19. TA.52 & R51005 & 5 & 5 & $2.1 \pm 2.8$ & $-7.1 \pm 4.1$ & $-1.1 \pm 4.8$ & 0.0 & 5 & 0 & $14 \pm 5.3$ & $4.5 \pm 2.4$ & $8.4 \pm 7.5$ & 0.0004 \\
\hline 20. TA-16 & 99348 & 5 & 4 & $20 \pm 6.9$ & $-3.3 \pm 2.4$ & $-0.3 \pm 8.5$ & 0.0 & 5 & 2 & $242 \pm 20$ & $0.8 \pm 1.6$ & $20 \pm 75$ & 0.00111 \\
\hline 21. Pronater P-2 & 91977 & 5 & 5 & $-2 \pm 1.9$ & $-5.1 \pm 4.6$ & $-27 \pm 1.4$ & 0.0 & 5 & 3 & $11 \pm 4.1$ & $0.7 \pm 1.7$ & $3.2 \pm 5.5$ & $0 . \mathrm{mm2}$ \\
\hline 22. 7'A.54 & 91963 & 5 & 5 & $2 \pm 3.2$ & $-2.9 \pm 2.2$ & $-1 \pm 4.2$ & 0.0 & 5 & 1 & $132 \pm 14$ & $-0.1 \pm 2.1$ & $23 \pm 70$ & 0.0012 \\
\hline 23. TA.49 & 91727 & 5 & 5 & $-1.7 \pm 1.5$ & $-4.2 \pm 4.5$ & $-2.8 \pm 3.6$ & 0.0 & 5 & 2 & $1.3 \pm 3.8$ & $1.3 \pm 2.9$ & $4.6 \pm 5.1$ & $0.00 \times 12$ \\
\hline 24. TA-23 & 91842 & 5 & 5 & $-2.1 \pm 2.1$ & $-6.5 \pm 4.3$ & $-2.9 \pm 2.2$ & 0.0 & 5 & 1 & $12 \pm 4$ & $1 \pm 2.6$ & $6.9 \pm 8.6$ & O.M00:3 \\
\hline 25. TA.39 & 86689 & 5 & 5 & $-1.7 \pm 1.9$ & $-4.2 \pm 4.3$ & $-2.6 \pm 2.5$ & 0.0 & 5 & 2 & $9 \pm 4.5$ & $-0.3 \pm 2.6$ & $3.7 \pm 8$ & 0,0002 \\
\hline Onsite Gmup Summary & 99RR65 & 55 & 54 & $25 \pm 6.9$ & $-8 \pm n$ & $-2.1 \pm 1.8$ & 0.0 & 55 & 18 & $242 \pm 20$ & $-1.8 \pm 2.5$ & $8.3 \pm 33$ & $0 . \mathrm{mms}$ \\
\hline
\end{tabular}

Minimum Inelertahle l,imita $=2 \times 10^{-10} \mu \mathrm{Ci} / \mathrm{m} \ell\left({ }^{200} \mathrm{Pu}\right)$

$$
\begin{aligned}
& =2 \times 10^{-11} \mu \mathrm{Ci} / \mathrm{ml}(20 \mathrm{Pu}) \\
& =3 \times 10^{-11} \mu \mathrm{Ci} / \mathrm{ml}(\mathrm{mp} \mathrm{p})
\end{aligned}
$$

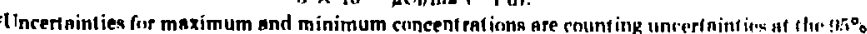

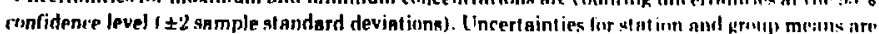

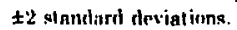

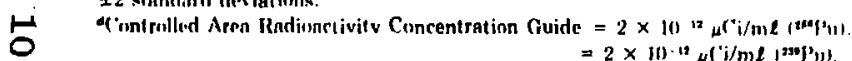

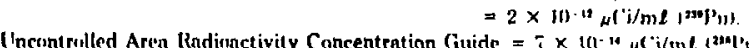

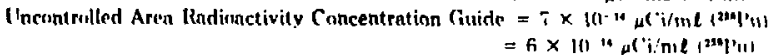


TABLE E-VIII

\section{ANNUAL ATMOSPHERIC URANIUM CONCENTRATIONS}

(concentrations in $\mathrm{pd} / \mathrm{m}^{\prime}$ )

\begin{tabular}{|c|c|c|c|c|c|c|c|}
\hline Station Location & $\begin{array}{c}\text { Total Air" } \\
\text { Volume }\left(\mathrm{m}^{*}\right)\end{array}$ & $\begin{array}{l}\text { Number of } \\
\text { Quarterly } \\
\text { Semples }\end{array}$ & $\begin{array}{c}\text { No. } \\
\text { Samples } \\
\text { <MDI }\end{array}$ & Max & Minr & Mean' & $\begin{array}{r}\text { Mean a } \\
7 \mathbf{C G}^{\mathbf{d}}\end{array}$ \\
\hline \multicolumn{8}{|c|}{ Regional Stations (28-44 km)-Uncontrolled Areas } \\
\hline $\begin{array}{l}\text { 1. Española } \\
\text { 2. Pojogaque } \\
\text { 3. Sant a Fe }\end{array}$ & $\begin{array}{l}78607 \\
81428 \\
86956\end{array}$ & $\begin{array}{l}4 \\
4 \\
4\end{array}$ & $\begin{array}{l}0 \\
0 \\
2 \\
\end{array}$ & $\begin{array}{r}112 \pm 19 \\
116 \pm 18 \\
81 \pm 24\end{array}$ & $\begin{array}{l}64 \pm 19 \\
34 \pm 18 \\
15 \pm 17\end{array}$ & $\begin{array}{l}85 \pm 64 \\
75 \pm 87 \\
28 \pm 28\end{array}$ & $\begin{array}{l}0.0007 \\
(1.1 \%)(1) \\
0.00003\end{array}$ \\
\hline Regional (iroup Summary & 246991 & 12 & 2 & $116 \pm 18$ & $15 \pm 17$ & $62 \pm \bar{i}$ & U. (KK)' \\
\hline
\end{tabular}

Perimeter Statione (0-4 km)-Uncontrolled Areas

\begin{tabular}{|c|c|c|c|c|c|c|c|}
\hline 4. Harranca School & 79344 & 4 & () & $8.5 \pm 19$ & $36 \pm 19$ & $51 \pm 61$ & 0.0005 \\
\hline 5. Arkansas Ave & 72708 & 4 & 1 & $5,8 \pm 24$ & $18 \pm 21$ & $34 \pm 32$ & 0. (KKI:3 \\
\hline o. Cumbres School & 80559 & 4 & 1 & $69 \pm 27$ & $17 \pm 19$ & $3 i \pm 36$ & 0. (KKH \\
\hline 7. 48 th Street & 85773 & 4 & 0 & $62 \pm 25$ & $24 \pm 37$ & $37 \pm ; 7$ & $0.000(14$ \\
\hline 8. LA Airport & 95359 & 4 & 0 & $179 \pm 22$ & $45 \pm 16$ & $88 \pm 94$ & $0 .(x)] 11$ \\
\hline 9. Bayo STP & 90449 & 4 & 0 & $120 \pm 16$ & $23 \pm 16$ & $60 \pm 104$ & $0 .(x))^{-}$ \\
\hline 10. Gulf Station & 71951 & 4 & 1 & $1901 \pm 32$ & $28 \pm 12$ & $78 \pm 6.1$ & $0 .(x \times) y$ \\
\hline 11. Royal Crest & 69755 & 4 & 0 & $109 \pm 26$ & $18 \pm 20$ & $71 \pm 70$ & $0.0 \times 18$ \\
\hline 12. White Ruck & 81752 & 4 & 2 & $98 \pm 18$ & $35 \pm 18$ & $60) \pm 71$ & $\left.0 .(K)_{1}\right)$ \\
\hline 13. Pajaritu Acres & 76581 & 4 & 1 & $65 \pm 28$ & $17 \pm 19$ & $35 \pm 42$ & $0.0 \mathrm{~K} \times \mathrm{HI}$ \\
\hline 14. Bandelier & 76581 & 4 & 1 & $81 \pm 31$ & $x \pm 20$ & $4: 1 \pm 46$ & $0.1 K \times 15$ \\
\hline Perimeter (iroup Summary & 8749336 & 44 & 6 & $1(x) \pm 3: ?$ & $k \perp 20$ & $54 \pm 73$ & (1.)KKKFi \\
\hline
\end{tabular}

\section{Onsite Stations-Controlled Areas}

\begin{tabular}{|c|c|c|c|c|c|c|c|}
\hline 15. TA-21 & 78717 & 4 & () & $251 \pm 5 \pi$ & $4.5 \pm 1.9$ & $R: 3 \pm 70$ & $0 .(x)(x) 14$ \\
\hline 16. 'TA-6i & 86709 & 4 & 1 & $59 \pm 25$ & $7 \pm 17$ & $3: 3 \pm 49$ & 0. (KKHIL? \\
\hline 17. TA-53 (LAMPF) & 82759 & 4 & () & $97 \pm 18$ & $4: 1 \pm 18$ & $79 \pm 76$ & $0 .(x \times 1) \mathrm{H}$ \\
\hline 18. Well HM-1 & 84081 & 4 & 1 & $38 \pm 24$ & $\bar{i} \pm 18$ & $30 \pm: 34$ & (1.0KKHI) \\
\hline 20. TA-16 & 92287 & 4 & 2 & $6: 1 \pm 2: 1$ & $6 \pm 16$ & $26 \pm: 13$ & O.onKHII \\
\hline 21. Buster P.2 & 84905 & 4 & 1 & $107 \pm 23$ & $T \pm 18$ & $39 \pm 4(i$ & 0.0 XKKI \\
\hline 24. TA-ity & 84770 & 4 & 2 & $R: 1 \pm 2: 3$ & $7 \pm 18$ & $39 \pm 79$ & ().(XKH): \\
\hline 25. TA-ig & $7958: 1$ & 4 & 2 & $62 \pm 25$ & $8 \pm 19$ & $26 \pm 30$ & $0.0(x)(x) 1$ \\
\hline Onsite (iroup Summary & 921277 & 44 & 10 & $2 \pm$ & $6 \pm 1 x$ & $\pi() \pm 6-1$ & (1.) (Hस) \\
\hline
\end{tabular}

- Air volumes $\left(\mathrm{m}^{2}\right)$ at average ambient conditions of $77 \mathrm{kPa}$ barumetric pressture amd $1.7($.

- Minimum detectable limit $=1 \mathrm{pk} / \mathrm{m}^{*}$.

Clncertainties for maximum and minimum concentrations are crounting uncertainties at the $49^{\circ} 0^{\circ}$

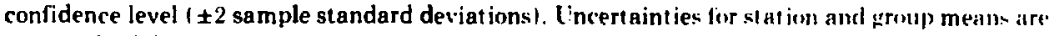
\pm 2 st andard devialions.

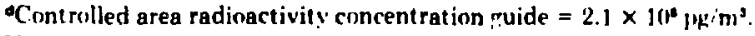

Uncontrolled area radioactivity concentration quide $=9 \times 10^{\circ} \mathrm{pq} / \mathrm{m}^{*}$.

Note: One curie of natural uranium is equivalent to 31 ho kf at natural uranium. Hence. uranium masses can be converted to the DOE "uranium special eurif." bs using the filctur $3.3 \times 10^{-11} \mu \mathrm{Ci} / \mathrm{pg}$. 
TABLE E-IX

ANNUAL ATMOSPHERIC "Am CONCENTRATIONS

|concentrations in $\mathrm{aCi} / \mathrm{m}^{*}\left(10^{-10}{ }_{\mu} \mathrm{Ci} / \mathrm{m} \ell\right) \mid$

\begin{tabular}{|c|c|c|c|c|c|c|c|}
\hline Station Location & $\begin{array}{c}\text { Total Air } \\
\text { Volume }\left(\mathrm{m}^{2}\right)^{a}\end{array}$ & $\begin{array}{c}\text { Number of } \\
\text { Quarterly } \\
\text { Samples }\end{array}$ & $\begin{array}{c}\text { No } \\
\text { Samples } \\
\text { <MDL } \\
\end{array}$ & $\operatorname{Max}^{e}$ & $\mathbf{M i n}^{\mathrm{e}}$ & Mean $^{\circ}$ & $\begin{array}{c}\text { Mean as } \\
\% \mathrm{CG}^{\circ}\end{array}$ \\
\hline \multicolumn{8}{|c|}{ Hegional Stations $(28-44 \mathrm{~km})$-Uncontrolled Areas } \\
\hline 3. Santa $\mathrm{Fe}$ & 86956 & 4 & 4 & $-1.1 \pm 4.6$ & $-6 \pm 10$ & $-3.1 \pm 4.7$ & 0.0 \\
\hline Reginnal Group Summary & 86956 & 4 & 4 & $-1.1 \pm 46$ & $-6 \pm 10$ & $-3.1 \pm 4.7$ & 0.0 \\
\hline \multicolumn{8}{|c|}{ Perimeter Stations $(0-4 \mathrm{~km})$-Uncontrolled Areas } \\
\hline 6. Cumbres & 80559 & 4 & 4 & $-0.5 \pm 7.1$ & $-1.3 \pm 5.1$ & $-0.9 \pm 1$ & 0.0 \\
\hline R. LA Airport & 91337 & 4 & 4 & $0.1 \times 4.2$ & $-4.6 \pm 5.2$ & $-1.5 \pm 4.3$ & 0.0 \\
\hline 9. Hayn STP & 90449 & 4 & 4 & $1.2 \pm 6.8$ & $-1.1 \pm 4.4$ & $-0.7 \pm 1.8$ & 0.0 \\
\hline 12. White Rnck & 81752 & 4 & 4 & $0.9 \pm 5.1$ & $-1.8 \pm 6.5$ & $-0.7 \pm 2.6$ & 0.0 \\
\hline Perimeter Group Summary & 344097 & 16 & 16 & $1.2 \pm 6.8$ & $-4.6 \pm 5.2$ & $-1 \pm 2.6$ & 0.0 \\
\hline \multicolumn{8}{|c|}{ Onsite Stutions-Controlled Areas } \\
\hline 16. TA.6 & 86709 & 4 & 4 & $3.8 \pm 9.1$ & $-5.1 \pm 7.6$ & $-1.6 \pm 6.2$ & 0.0 \\
\hline 17. TA.53 (LAMPF) & 82759 & 4 & 4 & $2.5 \pm 7.2$ & $-1.8 \pm 5.1$ & $-0.3 \pm 3.5$ & 0.0 \\
\hline 20. TA.16 & 92287 & 4 & 4 & $-0.8 \pm 4.6$ & $-3.9 \pm 5.6$ & $-2.4 \pm 3.8$ & 0.0 \\
\hline 21. Hinster P.2 & 849015 & 4 & 4 & $0.0 \pm 5$ & $-1.6 \pm 6.2$ & $-0.8 \pm 1.1$ & 0.0 \\
\hline 22. TA. 54 & 87122 & 4 & 3 & $37 \pm 10$ & $-0.7 \pm 4.8$ & $5 \pm 20$ & 0.00008 \\
\hline 23. TA-49 & 84773 & 4 & 4 & $1.9 \pm 11$ & $-1.8 \pm 6.4$ & $-0.4 \pm 3.5$ & 0.0 \\
\hline Onsite Group Summary & 518555 & 24 & 23 & $37 \pm 10$ & $-.5 .1 \pm 7.6$ & $-0.1 \pm 9.4$ & 0.0 \\
\hline
\end{tabular}

- Air volumes ( $\left.\mathrm{m}^{2}\right)$ at average ambient conditions of $77 \mathrm{kPa}$ harnmetric uressure and $15 \mathrm{f}^{\circ}$

'Minimum detectable limit $=2 \times 10^{-10}{ }_{\mu} \mathrm{Ci} / \mathrm{ml}$.

Incerlainties for maximum and minimum concentrations are count ing uncertaint ies at the $3: \%$ confidence level ( \pm 2 sample deviat inns). ('ncertainties for stat ion and yroup neans are \pm 2 ' standard deviations.

ocont rovllod aren radionactivity concentration quide $=5 \times 10^{-0} \mu(\mathrm{i} / \mathrm{i} \ell$

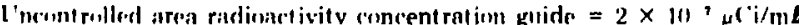


TABLE E-X

\section{LOCATIONS OF SURFACE AND GROUND WATEK STATIONS}

\begin{tabular}{|c|c|c|c|c|}
\hline Station & $\begin{array}{c}\text { Latitude } \\
\text { or } \\
\text { N-S } \\
\text { Coordinate }\end{array}$ & $\begin{array}{c}\text { Longitude } \\
\text { or } \\
\text { E-W } \\
\text { Coordinate }\end{array}$ & $\underset{\text { Designation }}{\text { Map }}$ & Type $^{b}$ \\
\hline Chama & $36^{\circ} 05^{\prime}$ & $106^{\circ} 07^{\prime}$ & -- & sW \\
\hline Grande & $36^{\circ} 12^{\prime}$ & $105^{\circ} 58^{\prime}$ &.-- & sW \\
\hline rande & $35^{\circ} 52^{\prime}$ & $106^{\circ} 08^{\prime}$ &.-- & sW \\
\hline Grande & $35^{\circ} 37^{\prime}$ & $106^{\circ} 19^{\circ}$ & $\cdots$ & SW \\
\hline io Grande & $35^{\circ} 17^{\prime}$ & $106^{\circ} 36^{\prime}$ &..- & sW \\
\hline & $35^{\circ} 40^{\prime}$ & $106^{\circ} 44^{\prime}$ & $\cdots$ & SW \\
\hline eservoir & N105 & W090 & 1 & SW \\
\hline & N300 & E100 & 2 & SW \\
\hline & N060 & E395 & 3 & (iWS \\
\hline n & $\mathrm{S} 280$ & E180 & 4 & SW \\
\hline ing & N080 & E550 & 5 & GWI \\
\hline anyond & & & & \\
\hline ition & -.. & $\ldots$ & 6 & $\left({ }_{x} W D\right.$ \\
\hline (F.G.Sed) & $\ldots$ & $\ldots$ & 7 & (GWD \\
\hline (F.G.Sed) & -.- & $\cdots$ & 8 & GWD \\
\hline (Basalts) & & $\cdots$ & 9 & GWD \\
\hline ter & $\ldots$ & $-\cdots$ & 10 & SW \\
\hline ter (Sanitary Effluents) &.-- & $\cdots$ & 11 & SW \\
\hline
\end{tabular}

\section{Water Supply \\ Distribution}

Fire Station 1

Fire Station 2

Fire Station 3

Fire Station 4

Fire Station 5

Los Alamos Field

LA-1B

LA-2

LA-3

N080

E015

N100

E120

S085

N185

S010

E375

E070

W065

12

13

D

14

15

16

D

D

D

D

N115

E530

GWD

N125

E505

GWD

$\mathrm{N} 130$

E490

GWD

LA-4

E405

(IWD

LA-5

N076

LA- 6

E435

GWD

E465

GWD

Guaje Field

G-1

G-1A

G-2 
TABLE E-X (Cont)

$\begin{array}{cc}\text { Latitude } & \text { Longitude } \\ \text { or } & \text { or } \\ \text { N-S } & \text { E-W }\end{array}$

Map

Coordinate Coordinat

\section{Designation * Type}

Pajarito Field

PM-1

PM -2

N030

E305

30

GWD

S055

E202

PM-3

Water Canyon Gallery

N040

E255

W125

GWD

GWD

S040

32

33

GWD

\section{Noneffluent Areas}

Test Well 1

Test Well :3

Deep Test -5A

Test Well-8

Deep Test-9

Deep 'Test -10

Canada del Buey

N070

N080

E345

E215

$\$ 110$

E090

N035

E170

$\mathrm{S} 155$

S120

N010

Pajarito Canyon

$\mathrm{S} 060$

Water Canyon

S090

Test Well 2

N120

E140

E125

E150

E2!5

E090

E150)

34
35
36
37
38
39
40
41
42
43

GWD

GWD

GWD

GWD

GWD

GWD

SW

SW

SW

GWD

\section{Effluent Release Area}

Acid-Pueblo Canyon

(Former Release Area)

Acid Weir

Pueblo 1

N125

N130

Pueblo 2

N120

Pueblo :3

Hamilton Bend Spring

N085

N110

Test Well $1 \mathrm{~A}$

N070

Test Well 2A

N120

E070

E080

E155

E315

E255

E335

E140

DI' - Los Alamos Canyon

DPS-1

N090

E160

N080

N085

N080

N080

N080

N070

N065

E200

E070

E120

E210

E220

E245

Obs: Hole LAO-4.5

Sandia Canyon

SCS. 1

SCS-2

SCS-3

N080

E270

44

45

46

47

48

49

50

sw

SW

SW

SW

GW

GWS

GWS

N060

E040

N050

E140

E185

51

SW

SW

GWS

GWS

GWS

GWS

GWS

GWS

58

$\begin{array}{ll}59 & \text { SW } \\ 60 & \text { SW }\end{array}$

61 SW 
TABLE E-X (Cont)

Station

Mortandad Canyon

GS-1

MCS-3.9

Obs. Hole MCO-3

Obs. Hole MCO-4

Obs. Hole MCO-5

Obs. Hole MCO-6

Obs. Hole MCO-7

Obs. Hole MCO-7.5

10-Site Canyon
Latitude Longitude

or

N-S

Coordinate

N040

N040

N040

N035

N030

N030

N025

N030

N025

E100

E140

E110

E150

E160

E175

E180

E190

E130

\section{E-W Map}

Coordinate Designation" Type
SW

SW

(iWS

GWS

GWS

GWS

(iWS

GWS

SW

- See Fig. 11 for numbered locations.

bSW = surface water; (jWD = deep or main aquifer; (iWS = shallow or allusial anuiler; $I)=$ water supply distribution system.

cSee Fig. 6 for regional locations.

'Puye Formation 7 stations; Tesuque Fm (F. G. Sed) 0 stations this period; Tesuque Fm (C. G. Sed) 9 stations; Tesuque (basalts) 3 stations; surface water 3 stations; surface water (sanitary effluents) 1 stacion. 
TABLE E-XI

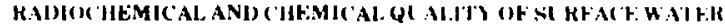
FROM RECIONAL. STATIONS

\begin{tabular}{|c|c|c|c|c|c|c|c|c|}
\hline \multirow[b]{2}{*}{ Scation } & \multirow[b]{2}{*}{$\begin{array}{c}\text { No. of } \\
\text { Anelycen }\end{array}$} & \multicolumn{7}{|c|}{$\begin{array}{l}\text { Rudiuchemic al } \\
\text { (average of a number of analyses) }\end{array}$} \\
\hline & & $\begin{array}{c}\mathrm{H} \\
\left(10^{-*} \mu \mathrm{C} / \mathrm{m} L\right) \\
\end{array}$ & $\begin{array}{c}1 \times(\mathrm{C}) \\
(10 \cdot \mu(\mathrm{i} / \mathrm{m})\end{array}$ & $\begin{array}{c}\mathrm{m}^{\mathrm{m} u} \\
(10 \cdot \mu(\mathrm{v} / \mathrm{m} l) \\
\end{array}$ & $\begin{array}{c}m \mathrm{Pu}_{u} \\
\left.(10)^{\prime} \mu \mathrm{CV} / \mathrm{m} l\right)\end{array}$ & $\begin{array}{c}\text { Graas } \alpha \\
\left(10^{-0} \mu(\mathrm{i} / \mathrm{m} /)\right.\end{array}$ & $\begin{array}{c}\text { Groen } \beta \\
\left(10^{\circ} \cdot \mu \mathrm{CV} / \mathrm{m} l\right)\end{array}$ & $\begin{array}{c}\text { Total U } \\
(\mu / / 2)\end{array}$ \\
\hline Chamita & 2 & $0.7 \pm 0.0$ & $22 \pm 24$ & $-042 \pm 134$ & $-11111 \pm(3(x)$ & $4.8 \pm 0.6$ & $13 \neq 79$ & $4.2 \pm 2.6$ \\
\hline Fimbudu & 2 & $0.8 \pm 1.0$ & $-1 \pm 27$ & $0(n) \pm 010.1$ & $-11192 \pm 13.02$ & $0.3 \pm 3.1$ & $5.5 \neq 8.5$ & $1.8 \pm 17$ \\
\hline Otuwi & 1 & $0.3 \pm 0.6$ & $11 \pm 80$ & $-1105 \pm 1114$ & $-110.1 \pm 11.04$ & $1.4 \pm 2.4$ & $76 \neq 2.4$ & $3.6 \pm 0 . \mathrm{H}$ \\
\hline Cochitı & 2 & $0.5 \pm 0.3$ & $-24 \pm 45$ & $0.00) \pm(10101$ & $-6101=11014$ & $1.1 \pm 3.1$ & $70 \pm 3.0$ & $3.1 \pm 1.8$ \\
\hline Hernalilio & 2 & $07 \pm 06$ & $-x \pm 63$ & $-10(12 \pm 010.1$ & $0(n) \neq 002$ & $31 \pm 5.4$ & $79 \pm 3.8$ & $3.5 \pm 2.8$ \\
\hline Jemez & 2 & $0.8 \pm 0.1$ & $20 \pm 56$ & $0.02 \pm 061$ & $18.00 \pm 0.144$ & $2.1 \pm 3.7$ & $14 \pm 0.6$ & $1.7 \pm 0.3$ \\
\hline Nu of Analyses & & 11 & 11 & 11 & 11 & 11 & 11 & 11 \\
\hline Minimuns & & $0.1 \pm 0.6$ & $-411 \pm 40$ & $-10.10 ; \pm 0114$ & $-610.3 \pm 11010.3$ & $-0.8 \pm 2.0$ & $2.5 \pm 1.2$ & $1.2 \pm 0.8$ \\
\hline Maximum & & $1: \pm 0.8$ & $40 \pm 80$ & $0(n) \pm 0, \ldots ?$ & $1100 \pm 0112$ & $5.0 \pm 4.0$ & $16 \pm 3.4$ & $5.1 \pm 0.8$ \\
\hline Average & & $0.7 \pm 0.5$ & $2 \pm 47$ & $-0.181 \neq 0.013$ & $-001 \pm 000.1$ & $2.4 \pm 4.1$ & $9.2 \pm 8.8$ & $3.0 \pm 2.4$ \\
\hline
\end{tabular}

Chemical

(concontrations in medt, one unalynin)

\begin{tabular}{|c|c|c|c|c|c|c|c|c|c|c|c|c|c|c|c|c|}
\hline \multirow[b]{2}{*}{ Stutiun } & & \multirow[b]{2}{*}{ pH } & \multirow{2}{*}{$\begin{array}{c}\text { Cond } \\
(m S / m)\end{array}$} \\
\hline & Sio, & c. & Mc & $\mathbf{K}$ & $\ldots N_{4}$ & $1 U_{1}$ & H( (1), & Po, & so. & $\mathrm{ct}$ & $\boldsymbol{F}$ & No, & TDS & Hurd & & \\
\hline Chamulu & 11 & 49 & 12 & 3.6 & $34 ;$ & 11 & litt & 11.6 & 114 & 13 & 0.3 & 13 & $\$ 44$ & (nw) & $x .6$ & $5 \times 3$ \\
\hline Fimbudo & 16 & 25 & 5 & 2.9 & 12 & 11 & 1.34 & $<11 !$ & 39 & 4 & 0.4 & 1.4 & 216 & Mo & N.6 & $2 t i$ \\
\hline (n)wi & 16 & $3 \mathbf{4}$ & 8 & 2.9 & 21 & 0 & 154 & 1.2 & 64 & 7 & 0.5 & 1.0 & $i(\mathbf{x})$ & 13.5 & H. 7 & $\$ 6$ \\
\hline r'schuu & 16 & 35 & 8 & 2.9 & 21 & "1" & lst & 0.7 & ist & $i$ & w.t & 11.2 & 274 & $1 ; 4$ & $A N$ & :4t \\
\hline Hernalitlo & 16 & 39 & 8 & 3.8 & 34 & 11 & 151 & 1.11 & 6i3 & 19 & 0.5 & 0.3 & $3 \%$ & $1+11$ & H. 9 & +2 \\
\hline Jemex & 26 & 29 & 5 & 7.2 & 45 & 11 & 170 & 0.1 & 20 & 52 & 0.8 & 0.3 & 376 & 100 & $\rtimes .7$ & 45 \\
\hline N(1, i) Analywea & 6 & 6 & 6 & 6 & i) & is & 6 & ij & 6 & 6 & 6 & ti & 6 & 6 & $b$ & i \\
\hline Mınııum & 11 & 25 & 5 & 2.9 & 12 & $"$ & $1: 34$ & $<0.1$ & 20 & i & 0.3 & 0.2 & 216 & $v(x)$ & H.6 & 20 \\
\hline Muximum & 26 & 49 & 12 & $7: 2$ & $4 i$ & & $17 i$ & 1.2 & 114 & 52 & 0.8 & 1.4 & 444 & $1 *(x)$ & $x . y$ & 501 \\
\hline Avernge & $17 \pm 10$ & $36 \pm 17$ & $8 \pm 5$ & $B . H \pm B .4$ & $2 N \pm 24$ & 11 & $1 ; x+28$ & $0.6 \pm 0.9$ & $59 \pm 63$ & $17 \pm i+6$ & $0.5 \pm 0.3$ & $0.8 \pm 1.0$ & $323 \pm 160$ & $132 \pm 57$ & $H 7 \pm 11:$ & i $19 \pm 1$ \\
\hline
\end{tabular}

Note: \pm value represents twice the standard devistion of the distribution of observed values

unlew only one snalyais is reported, then the value reprewents twice the uncertainty term

for that andysis. 
HAIOCHFMICAL AND CHEMICAL QUALITY (IF SL RFACF, ANI) GHOUND WATEK FROM PEKIMETEK S'IATIONS

Hadiochemical

Station

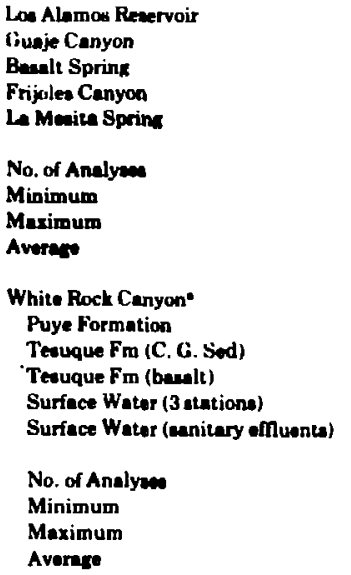

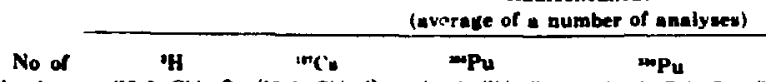

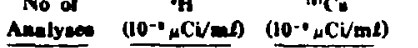

$(10 \cdot 0 \cdot(\mathrm{i} / \mathrm{mL})$

$\underline{\left(10^{-} \cdot{ }^{n} \mathrm{Ci} / \mathrm{m} \theta\right)}$

$\underset{(10 \cdot 0 \mu \mathrm{C} v / m}{\text { Grom }}$

Gromed

Total U

$0.6 \pm 0.7$
$0.7 \pm 0.6$
$0.8 \pm 0.6$
$0.8 \pm 0.1$

$13 \pm 16$

(1).(1) \pm 0.00

$-0.02 \pm 0.03$

$0.01 \pm 0.06$

$0.04 \pm 0.04$

$\begin{aligned} 0.04 & \pm 0.04 \\ -0.02 & \pm 0.05\end{aligned}$

$0.2 \pm 0.1$

(ny)

$-15 \pm 70 \quad-6113 \pm 0.010$

$-10 \pm 40 \quad-10.115 \pm 0.02$

$-0.01 \pm 0.02$

$3.7 \pm 0.4 \quad 0.4 \pm 0.8$

$8.9 \pm 2.6 \quad 1.9 \pm 0.8$

7

$i$

$0.3 \pm 0.6 \quad-40 \pm 60 \quad-0.033^{\prime} \pm 0.15$

$0.8 \pm 0.6 \quad 18 \pm 42 \quad 0.01 \pm 0.11$

7

$-0.0 .3 \pm 0.04$

$0.04 \pm 0.04$

$3.4 \pm 1.7$

$0.1 \pm 0.3$

7

7

$-0.3 \pm 1.2$

$2.8 \pm 1.2$

7

$0.00 \pm 0.05$

$1.2 \pm 4.2$

$8.9 \pm 2.6$
$5.4 \pm 5.3$

$14 \pm 2.8$

$2.4 \pm 10$

\section{$-0.4 \pm 0 \quad-4 \pm 54$}

$-0.1 \pm 0.3$

$-0.2 \pm 0.1$

$-4 \pm 54$
$12 \pm 35$

$-0.152 \pm 11.04$

$0.00 \pm 0.04$

$0.01 \pm 0.01$

$1.1+$

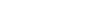

$1.1 \pm 1.2$

$-0.101 \pm 11.04$

$\begin{array}{rrr}0.2 \pm 0.1 & -2.1 \pm 21 & -11.11 \pm 0.04 \\ 0.2 \pm 1.1 & 0 \pm 20 & 0.111 \pm 0.05\end{array}$

$0.00 \pm 0.02$

$1.1 \pm 12$

$3.2 \pm 1.8$

$\begin{array}{lll}0.3 \pm 1.1 & 2.3 \pm 1.1 & 0.5 \pm 1.9\end{array}$

$-0.03 \pm 0.07$

$0.6 \pm 1.9$

$30 \pm$ bu $-11.02 \pm 0.14$

23

$-0.7 \pm 0.6$

$0.7 \pm 0.6$

23

$-70 \pm 80$

$2: 1$

$50 \pm 60$

$-0.14 \pm 0.04$

$0.14 \pm 0.22$

23

$-1.1 \pm 2.4$

$2.8 \pm 1.9 \quad 0.4 \pm 1.5$

$-0.06 \pm 0.06$

$0.03 \pm 0.03$

23

3
$1.4 \pm 1$

$0.4 \pm 1.5$
$0.5 \pm 0.8$

$-0.2 \pm 0.6$

$2 \pm 52$

$0.00 \pm 0.03$

$\begin{array}{ll}4.9 \pm 2.6 & 16 \pm 3.8\end{array}$

23

$0.0 \pm 0.8$

$23 \pm 4.6$
$1.8 \pm 9.3$ 
TABLE E.XII (Cont)

Chemicul

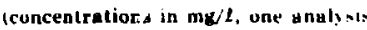

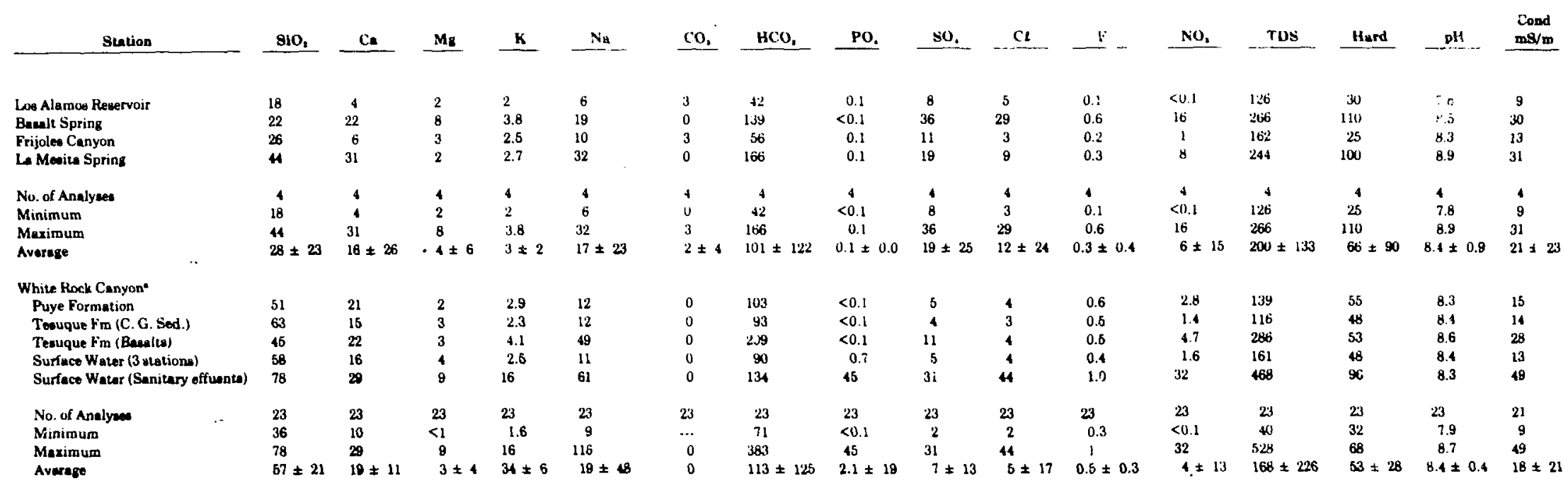

"Average of a number of amalyose.

Nure: \pm value reprevente twice the atandard deviation of the distribution of ubserved values unlew only analyais is reported. Then the valuo reprevento iwice the uncertainty terts for that enalyais. 
TABLE E-XIII

HADIOCHIMM :AL, AND CHEMIC:AI, QUALI:Y OF W'T'BH FHOM

MUNICIPAL SUPPI,Y AND DIST'KIBI'TION

\begin{tabular}{|c|c|c|c|c|c|c|c|c|}
\hline \multirow[b]{2}{*}{ Location } & \multirow[b]{2}{*}{$\begin{array}{c}\text { No. of } \\
\text { Analysea }\end{array}$} & \multirow[b]{2}{*}{ 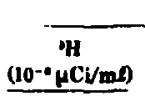 } & \multicolumn{3}{|r|}{ Rudiochemicul } & \multirow[b]{2}{*}{$\begin{array}{c}\text { Gross } \alpha \\
\left(10^{-1} \mu \mathrm{Ci} / \mathrm{ml}\right)\end{array}$} & \multirow[b]{2}{*}{$\begin{array}{c}\text { Grose } \beta \\
\left(10^{-0} \mu \mathrm{Ci} / \mathrm{ml}\right)\end{array}$} & \multirow[b]{2}{*}{$\begin{array}{c}\text { Total U } \\
(\mu / / l)\end{array}$} \\
\hline & & & 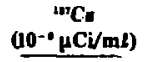 & $\begin{array}{c}{ }^{m m} \mathrm{Pu} \\
(10 \cdot \mu \mathrm{CV} / \mathrm{m} \ell)\end{array}$ & $\begin{array}{c}-\mathrm{P}_{\mathrm{u}} \\
(10-\cdot \mu \mathrm{C} \mathrm{i} / \mathrm{m} \ell) \\
\end{array}$ & & & \\
\hline \multicolumn{9}{|l|}{ Low Alamow Well Field } \\
\hline Wesl I.A.1B & 1 & $0.1 \pm 0.6$ & $0 \pm 40$ & $-0.04 \pm 0.0 .3$ & $-0.03 \pm 0.03$ & $9.0 \pm 6.0$ & $5.8 \pm 2.2$ & $6.2 \pm 1.2$ \\
\hline Well LA-2 & 1 & $-0.4 \pm 0.6$ & $27 \pm 3(1)$ & $-0.01 \pm 0.02$ & $0.00 \pm 0.01$ & $2.1 \pm 2.2$ & $5.5 \pm 2.0$ & $3.7 \pm 0.8$ \\
\hline Well LA-3 & 1 & $0.4 \pm 0.6$ & $35 \pm 36$ & $-0.02 \pm 0.02$ & $0.100 \pm 0.02$ & $0.9 \pm 1.8$ & $4.4 \pm 1.8$ & $2.1 \pm 0.8$ \\
\hline Well LA-4 & 1 & $0.0 \pm 0.6$ & $0 \pm 12$ & $-0.01 \neq 0.03$ & $0.00 \pm 0.0 \% 2$ & $-0.8 \pm 1.4$ & $2.6 \pm 2.6$ & $0.9 \pm 0.3$ \\
\hline Well l.A.5 & 1 & $0.2 \pm 0.6$ & $20 \pm 80$ & $-0.01 \pm 0.02$ & $0.00 \pm 0.02$ & $-0.01 \pm 1.6$ & $6.5 \pm 2.0$ & $1.8 \pm 0.8$ \\
\hline \multicolumn{9}{|l|}{ Guaje Well Field } \\
\hline Well G-1 & 1 & $-0.01 \pm 0.6$ & $40 \pm(0)$ & $-0.04 \pm 0.04$ & $-0.01 \pm 0.02$ & $-0.8 \pm 1.4$ & $3.7 \pm 1.6$ & $0.7 \pm 0.8$ \\
\hline Well G-IA & 1 & $0.1 \pm 0.6$ & $-4 \pm 26$ & $0.01 \pm 0.03$ & $-0.02 \pm 0.03$ & $-0.4 \pm 1.4$ & $4.0 \pm 1.8$ & $0.7 \pm 0.8$ \\
\hline We!l C-2 & 1 & $-0.2 \pm 0.6$ & $0 \pm 40$ & $-0.03 \pm 0.033$ & $0.00 \pm 0.02$ & $-0.5 \pm 1.6$ & $4.4 \pm 1.8$ & $1.4 \pm 0.8$ \\
\hline Well (i.3 & 1 & $0.0 \pm 0.6$ & $0 \pm 40$ & $0.001 \pm 0.01$ & $0.00 \pm 0.01$ & $-1.4 \pm 1.4$ & $3.1 \pm 1.6$ & $1.5 \pm 0.8$ \\
\hline Wall G-4 & 1 & $-0.3 \pm 0.6$ & $20 \pm 28$ & $0.00 \pm 0.033$ & $-0.02 \pm 0.03$ & $-0.3 \pm 1.2$ & $3.3 \pm 2.6$ & $1.0 \neq 0.8$ \\
\hline Well G-5 & 1 & $0.3 \pm 0.6$ & $15 \pm 14$ & $-0.02 \pm 0.03$ & $0.00 \pm 0.01$ & $0.3 \pm 1.4$ & $2.5 \pm 1.6$ & $1.8 \pm 0.8$ \\
\hline \multicolumn{9}{|l|}{ Pajarito Well Field } \\
\hline Well PM-1 & 1 & $0.5 \pm 0.6$ & $20 \pm 80$ & $-0.01 \neq 0.03$ & $-0.01 \pm 0.00$ & $1.1 \pm 1.8$ & $4.7 \pm 2.0$ & $2.2 \pm 0.8$ \\
\hline Well PM-2 & i & $0.8 \pm 0.6$ & $9 \pm: 38$ & $-0.01 \pm 0.0 x_{3}$ & $-0.01 \pm 0.02$ & $0.0 \pm 1.2$ & $2.0 \neq 1.6$ & $0.4 \pm 0.8$ \\
\hline Well PM-3 & 1 & $0.5 \pm 0.6$ & $10 \pm 40$ & $-0.01 \pm 0.02$ & $-0.01 \pm 0.01$ & $-0.2 \pm 1.8$ & $4.2 \pm 1.8$ & $1.0 \pm 0.8$ \\
\hline \multicolumn{9}{|l|}{ Water Canyon } \\
\hline Gellery & 1 & $0.3 \pm 0.6$ & $-4 \pm 26$ & $0.00 \pm 0.03$ & $0.00 \pm 0.03$ & $-0.7 \pm 1.0$ & $5.0 \neq 1.8$ & $0.4 \pm 0.8$ \\
\hline No. of Aralyane & & 15 & 15 & 15 & 15 & 15 & 15 & 15 \\
\hline Minimum & & $-0.4 \neq 0.6$ & $-4 \pm 26$ & $-0.04 \pm 0.04$ & $-0.03 \pm 0.03$ & $-1.4 \pm 1.4$ & $2.5 \pm 1.6$ & $0.4 \pm 0.8$ \\
\hline Maximum & & $0.8 \pm 0.6$ & $40 \pm 60$ & $0.01 \pm 0.03$ & $0.00 \pm 0.02$ & $9.0 \pm 6.0$ & $5.8 \neq 2.2$ & $6.2 \pm 1.2$ \\
\hline Average & & $0.2 \pm 0.7$ & $13 \pm 28$ & $-0.01 \pm 0.03$ & $-0.01 \pm 0.02$ & $0.6 \pm 5.0$ & $4.2 \pm 2.4$ & $1.7 \pm 3.0$ \\
\hline \multicolumn{9}{|l|}{ Distribution } \\
\hline Fire Station 1 & 2 & $0.6 \pm 1.3$ & $0 \pm 28$ & $0.010 \pm 0.05$ & $-0.01 \pm 0.04$ & $0.1 \pm 0.6$ & $2.8 \pm 0.1$ & $0.8 \pm 1.0$ \\
\hline Fire Station 2 & 2 & $0.7 \pm 0.3$ & $4 \pm 40$ & $0.00 \pm 0.01$ & $-10.01 \pm 0.03$ & $1.0 \pm 0.6$ & $3.4 \pm 3.0$ & $3.1 \pm 0.6$ \\
\hline Fire Station 3 & 2 & $0.5 \pm 0.3$ & $0 \pm 0$ & $0.00 \pm 0.00$ & $0.00 \pm 0.01$ & $0.9 \pm 0.6$ & $4.4 \pm 3.1$ & $1.3 \pm 1.4$ \\
\hline Fire Station 4 & 2 & $0.4 \neq 0.1$ & $30 \pm 0$ & $-0.01 \pm 0.01$ & $0.00 \pm 0.01$ & $-0.2 \pm 2.2$ & $2.7 \pm 1.7$ & $0.6 \pm 1.6$ \\
\hline Fire Station 5 & 2 & $0.6 \neq 0.6$ & $2 \pm 35$ & $-0.01 \pm 0.03$ & $-0.01 \pm 0.03$ & $0.4 \pm 1.0$ & $3.3 \pm 2.7$ & $1.1 \pm 3.1$ \\
\hline No. uf Analynes & & 10 & 10 & 10 & 10 & 10 & 10 & 10 \\
\hline Mininum & & $0.1 \pm 0.6$ & $-10 \pm 80$ & $-0.02 \pm 0.0 .33$ & $-0.012 \pm 0.04$ & $-0.9 \pm 0.7$ & $2.1 \pm 1.2$ & $0.0 \neq 0.8$ \\
\hline Maximum & & $1.0 \neq 0.6$ & $30 \pm 60$ & $0.01 \pm 0.02$ & $0.01 \pm 0.03$ & $1.2 \pm 0.6$ & $5.5 \pm 2.0$ & $3.3 \pm 0.8$ \\
\hline Average & & $0.5 \pm 0.5$ & $7 \pm 31$ & $0.00 \pm 0.02$ & $0.00 \pm 0.02$ & $0.5 \pm 1.3$ & $3.4 \pm 2.2$ & $1.4 \pm 2.3$ \\
\hline Los Alumos Woll LA.6" & 1 & $0.2 \pm 0.6$ & $60 \pm 60$ & $0.00 \pm 0.03$ & $-0.01 \pm 0.01$ & $-1.1 \pm 2.0$ & $3.1 \pm 1.8$ & $2.0 \pm 0.8$ \\
\hline
\end{tabular}


TABLE E-XIII (cont)

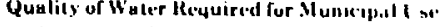

\begin{tabular}{|c|c|c|c|c|c|c|c|c|c|c|}
\hline Lacution & As & As & $\underline{B a}$ & cod & $\ldots \operatorname{cr}$ & $\mathbf{F}$ & $\mathrm{H}_{\mathrm{Z}}$ & No, & Pb & se. \\
\hline \multicolumn{11}{|l|}{ Isin Alamus Well rield } \\
\hline Well LA-IH & $\langle 0 \mid(x) 1\rangle$ & 110.: & $<1 ;$ & $<11+1$ & 1112 & $\because k$ & $<11 . \ln \times 1.5$ & $<2$ & $<n+1$ & CHAkE: \\
\hline Welll.A.2 & $\langle 0 .(x))$ & $\langle(n)\}$ & $(19.5)$ & <1) 11 & 1112 & $1:$ & $\angle 0,1 K M 55$ & $<2$ & $<0.01$ & $<11145$ \\
\hline Well L.A-3 & $<(1)(x)]$ & $<1001$ & $<11 . ;$ & $<10.11\}$ & $\because 1$ & in & $<1\rangle \ln x)_{5}$ & $<2$ & $<0.01$ & $<01815$ \\
\hline Well 1.A-4 & (1).|K) $\}$ & $<(1.01$ & $<115$ & <ni.11 & $<m, n$ & $0: 3$ & $<H(K N) i$ & $<2$ & $\langle U .|)$, & <io (1); $;$ \\
\hline Well LA-5 & $<0.001$ & $v(4)$ & $<0 . \hat{i}$ & $<11111$ & $<13114$ & us & $<0.00005$ & $<2$ & $<0.01$ & $<0.1045)$ \\
\hline \multicolumn{11}{|l|}{ Ciuaje Well Field } \\
\hline Well $(i-1$ & $<(1)(x) !$ & $<01$ & $<11:$ & $\langle 11 .(1)$ & $<1111$ & 114 & $\langle 0(K) \in 5$ & $<2$ & $<0.01$ & $<0,1 \mathrm{ALS})$ \\
\hline Well,ci-1A & $<0.0 \times 1$ & $<0.01$ & $<01.5$ & $<n m$ & $<n+1$ & 0.7 & C(B) & $<2$ & $\langle 0,(1)|$ & $\langle 11.101 ;\rangle)$ \\
\hline Well (;.2 & $<0 .(n) !$ & 6.14 & $<115$ & (1) 11$]$ & $<1111$ & 12 & $<13.00 \times 5$ & $<2$ & $<0.01$ & <11.LNGi) \\
\hline Well (i-i) & $<0 .(n) 1$ & $<(1.101$ & $<11.5$ & $<11111$ & $<111$, & 64 & $<0(x) 15$ & $<2$ & $0.0 \mathrm{i}$ & 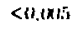 \\
\hline Well (i-4 & $<0(0)\}$ & $<0.01$ & $<115$ & $<11.111$ & $<1111$ & $0: 1$ & $<1) .0 \times 05$ & $<2$ & 0.01 & <Q.005) \\
\hline Well (;:) & $<0.001$ & $<0.01$ & $<0.5$ & $(1)+1$ & $<1111$ & 0.3 & $<0.0 \times 05$ & $<2$ & $<0.01$ & $<0.005$ \\
\hline Well (i.6 & 0.001 & $<0.01$ & $<0.5$ & $<n, n$ & $<11,1$ & $\cdots$ & $<0.00005$ & $\cdots$ & 0.19 & $<0.005$ \\
\hline \multicolumn{11}{|l|}{ Pajaritu Well field } \\
\hline Well P'M-1 & $<0.1001$ & $<001$ & $<0.5$ & $<0.11]$ & :1111 & 0.1 & $\langle(1)(x)(x)$ i & $<2$ & $<0.01$ & $<13.1 \times 5,5$ \\
\hline Weil YM.2 & $<0 .(0) 1$ & $<0.01$ & $<11.5$ & $<1111$ & $<01.01$ & 0.3 & $<1 . .0405$ & $<2$ & $<0.01$ & $<0.0065$ \\
\hline Well PM-3 & $<0.001$ & $<0, m$ & $<0.5$ & $\langle 1,(0)$ & $<1 ., 11]$ & 0.4 & $<0.0005$ & $<2$ & $<0.01$ & $<1.005$ \\
\hline \multicolumn{11}{|l|}{ Wuter ('anyun } \\
\hline Ciallery & $<0.601$ & $<0.01$ & $<0.5$ & $<11.114$ & $<1101$ & 0.2 & $<0$. lyous & $<2$ & $<0.01$ & $<0.005$ \\
\hline Nit. of Analysex & 16 & 16 & 16 & 16 & it & 15 & 16 & 15 & 16 & 16 \\
\hline Minimum & $<0 .(x) 1$ & $<10.01$ & $<0.5$ & $<1)(1)$ & $<111\rangle$ & 0.2 & $<0.0405$ & $<2$ & $<0,01$ & $<$ <i. (u15 \\
\hline Muximum & $\cdots$ & 0.05 & $\cdots$ & $\cdots$ & $n .12 z$ & 2.8 & $\cdots$ & $\cdots$ & 0.19 & $\ldots$ \\
\hline Average & $<0.001$ & $<0.01 \pm 0.02$ & $<0.5$ & $<11.01$ & $\langle 0.11\rangle] \pm 0.11\rangle$ & $0 . \bar{i} \pm 1.3$ & $<0.0005$ & $<2$ & $0.02 \pm 0.09$ & <11.(x) \\
\hline \multicolumn{11}{|l|}{ Distribution } \\
\hline Fire Sitution ! & $<0.001$ & $\langle 1\rangle, 01$ & $<(1.5)$ & $<0.171$ & U1x*; & $0: 3$ & $<0.00005$ & $<2$ & $<0.01$ & $<0.1415$ \\
\hline Fire Sitation 2 & $\langle(0 .(x) !$ & 0.01 & $<11.5$ & $<(1.11)$ & winest & 1). 7 & $<0.0 n \times 5$ & $<2$ & $<0.01$ & rutoks \\
\hline Fire Sitution 3 & $\langle(0,1001$ & $<0.01$ & $<1.5$ & $<1.91$ & $18 \min 3$ & 1.0 & (1).0\%105 & $<2$ & $<0.01$ & $<0.1005$ \\
\hline Fire Stution 4 & $<0.1001$ & $<0.111$ & $<11.5$ & $<11.111$ & $10 .(K) / 4$ & 0.4 & $<0.000 \%$ & $<2$ & $<0.0 I$ & $<$ <n. KNht \\
\hline Fire Station $\mathbf{j}$ & $<0.001$ & $<0.01$ & $<0 .$. & $\langle 0,(1)|$ & $<11.002$ & 0.6 & $<0.0005$ & $<2$ & $<0.01$ & $<0.705$ \\
\hline No. of Analyses & 5 & 5 & 5 & $s$ & i & 5 & 5 & 5 & 5 & 5 \\
\hline Minimum & $<0 . .01$ & $<0.11$ & $\leq 10.5$ & $<1)+11$ & $<11.10 \times 12$ & 0.3 & $<0.0005$ & $<2$ & $<0.01$ & <ir.custs \\
\hline Muximum & $\cdots$ & 0.01 & $\cdots$ & $\ldots \cdot$ & 16.1Kket & 1.0 & $\cdots$ & $\cdots$ & $\ldots$ & $\ldots$ \\
\hline Average & $<11.001$ & $<0.01 \pm 0 .(x)$ & $<0.5$ & $<0111$ & $\langle 0 .(n)= \pm(1 .(x))$ & $0.6 \pm 0.6$ & $<0.10 \times 05$ & $<2$ & $<0.01$ & $<0.005$ \\
\hline USEPA and NMBIA MPI. & 0.15 & 0.05 & 1.11 & 11.111 & 11.4 .5 & 2.0 & $0 .(k) 2$ & 45 & 0.05 & 0.01 \\
\hline Low Alanios Well L.A.6" & $<0.001$ & 0.23 & $<1 . .5$ & $<0.011$ & $01.1116 ;$ & 2.2 & $<0.00 \times 15$ & 2.2 & 0.006 & $<0.6 \times 15$ \\
\hline
\end{tabular}


Other Chemieul Cunstiluents

\begin{tabular}{|c|c|c|c|c|c|c|c|c|c|c|c|c|c|c|}
\hline \multirow[b]{2}{*}{ Location } & \multirow[b]{2}{*}{ sio, } & \multirow[b]{2}{*}{ Ca } & \multirow[b]{2}{*}{$\mathbf{M E}_{\mathbf{E}}$} & \multirow[b]{2}{*}{$\mathbf{K}$} & \multirow[b]{2}{*}{$\mathrm{Nu}$} & \multirow[b]{2}{*}{ (.o. } & \multirow[t]{2}{*}{ tion in $\mathrm{mg} / \mathrm{l}$} & \multirow[t]{2}{*}{ ne anulyois } & \multirow[b]{2}{*}{ so. } & \multirow[b]{2}{*}{ cl } & \multirow[b]{2}{*}{ TDS } & \multirow[b]{2}{*}{ Hard } & \multirow[b]{2}{*}{ pH } & \multirow{2}{*}{$\begin{array}{l}\text { Cond } \\
(\mathrm{mS} / \mathrm{m})\end{array}$} \\
\hline & & & & & & & & & & & & & & \\
\hline \multicolumn{15}{|c|}{ Los Alemus Well Fiold } \\
\hline Well LA-1B & 26 & 5 & $<1$ & 2.9 & I:A & ") & $\operatorname{lin}$ & $<0.1$ & $: 36$ & 15 & 5ASS & 30 & A.5 & it \\
\hline Well LA-2 & 23 & 5 & $<1$ & 1.4 & [NA & 0 & 127 & $<0.1$ & 13 & 12 & 280 & 25 & 9.11 & $2 \mathrm{y}$ \\
\hline Well LA-3 & 26 & 9 & $<1$ & 1.8 & 3 & " & 132 & 0.1 & 7 & 3 & 206 & 40 & H.X & 16 \\
\hline Well LA-4 & 29 & 8 & $<1$ & 2.2 & in & 0 & $\omega$ & 0.1 & 3 & 2 & 138 & 25 & 8.8 & 15 \\
\hline Well LA-6 & 29 & 5 & $<1$ & 1.5 & 32 & 0 & $\boldsymbol{3}$ & $<0.1$ & 4 & 2 & 184 & 25 & $y .1$ & 15 \\
\hline \multicolumn{15}{|l|}{ Gunje Well Field } \\
\hline Well (i-1 & 62 & 7 & $<1$ & 3.1 & 21 & 0 & (10) & 2.11 & 1 & 2 & 230 & 30 & $x .7$ & 15 \\
\hline Well $(\mathbf{i} \cdot 1 \mathrm{~A}$ & 56 & 6 & $<1$ & 3.61 & 25 & 0 & $n$ & 2.0 & 4 & 2 & 218 & 15 & H.K & 1.5 \\
\hline Well G-2 & 80 & 6 & $<1$ & 2.4 & : & 10 & In1 & 2.0 & 4 & 3 & 262 & 25 & N.! & 19 \\
\hline Well G.3 & 40 & 7 & 1 & 1.9 & 22 & 0 & $y_{5}$ & 2.0 & 3 & 2 & 212 & ;w & N. 7 & 16 \\
\hline Well G.4 & 34 & 10 & $\mathbf{3}$ & 2.0 & 14 & (1) & $\mathbf{H}_{\mathbf{1}}$ & 2.10 & 3 & 2 & 156 & 50 & H. & 15 \\
\hline $\begin{array}{l}\text { Well G.5 } \\
\text { Well G-6 }\end{array}$ & 31 & 10 & 4 & 2.1 & 11 & $v$ & $\infty$ & 2.0 & 4 & 3 & 158 & 60 & $\$ .6$ & li) \\
\hline \multicolumn{15}{|c|}{ Pajeziso Well Fiold } \\
\hline PM-1 & 32 & 14 & 6 & 3.6 & (2) & " & I:GS & $: 3.11$ & 5 & 6 & 2.45 & 85 & . .5 & 4 \\
\hline PM-2 & 54 & 5 & $\mathbf{3}$ & 2.2 & 11 & $" 1$ & i & 2.0 & 2 & 2 & 360 & 30 & x.t. & 12 \\
\hline PM-3 & 70 & 13 & $B$ & 3.6 & 17 & ) & 149 & $<0.1$ & 6 & 7 & 224 & 30 & H: & 25 \\
\hline \multicolumn{15}{|l|}{ Water Canyon } \\
\hline Gallery & 74 & 4 & 3 & 2 & 4 & 0 & i4 & 2.0 & 10 & 1 & 96 & 40 & $8 . \mathrm{x}$ & * \\
\hline No. of Aralymo & 13 & 15 & 15 & 15 & 1.5 & 15 & 15 & 15 & $1 \equiv$ & 15 & 15 & 15 & 15 & li. \\
\hline Minimum & 23 & 4 & $<1$ & 1.3 & $t$ & 0 & it & $<0.1$ & 2 & 1 & 96 & 15 & $7 . x$ & N \\
\hline Maximum & 74 & 14 & 8 & 3.6 & $15+$ & $\cdots$ & $: 154$ & 3.0 & 36 & 15 & 568 & ss & 9.0 & it \\
\hline Averaye & $42 \pm 34$ & $8 \pm 6$ & $2 \pm 4$ & $2.4 \pm 1.4$ & $32 \pm 73$ & 0 & {$[211) \pm 144$} & $1.3 \pm 2.1$ & $7 \neq 17$ & $4 \pm 8$ & $223 \pm 224$ & $36 \pm 35$ & $8.7 \pm 0.6$ & $2 A 1 \pm: 21 \mathrm{i}$ \\
\hline
\end{tabular}

Distribution

Fire Station

Fire Station ?

Fire Station 3

Fire Siation \&

$\begin{array}{lrcc}64 & 5 & 3 & 2.1 \\ 37 & 7 & <1 & 2.1 \\ 38 & 14 & 7 & 3.7 \\ 50 & 9 & 2 & 2.2 \\ 32 & 6 & 2 & 2.2 \\ & & & \\ 5 & 5 & 5 & 5 \\ 32 & 5 & <1 & 2.1 \\ 64 & 14 & 7 & 3.7 \\ 44 \pm 26 & 8 \pm 7 & 3 \pm 5 & 2.5 \pm 1.4\end{array}$

11
14
19
14
24
5
111
14
$24 \pm 19$

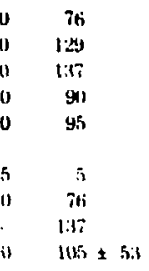

$\begin{array}{cc}2.0 & 2 \\ 2.0 & 6 \\ 0.1 & 6 \\ <0.1 & 4 \\ 0.1 & 0 \\ 5 & \\ 53 & 5 \\ <1.1 & 2 \\ 201 & 6 \\ 0.9 \pm 21 & 5 \pm\end{array}$

$\begin{array}{ll}2 & 150 \\ 4 & 228 \\ 8 & 262 \\ 3 & 210 \\ 4 & 200 \\ & \\ 5 & 5 \\ 2 & 190 \\ 8 & 262 \\ 4 \pm 5 & 214 \pm 57\end{array}$

45
35
90
45
25
5
5
25
90
$48 \pm 50$

h.

a. 3

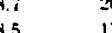

Nu. of Analywet

Maximum

Loe Alamoe Weli LA-6*

$$
<1
$$

1.2

il

19n

$<41$

is

$3 \quad 240$

he it

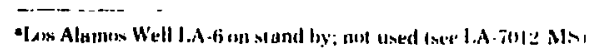

Note: \pm value repreasenta twice the standard deviation of the diatribution of ubserved values unless only one analysis is reported, then the value represents twice the uncertainty tertn foz that analyeis. 
TABLE E-XIV

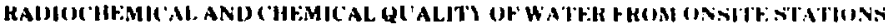

Hediur-hemicul

(average of a number of analyeen)

\begin{tabular}{|c|c|c|c|c|c|c|c|c|c|}
\hline Sitation & $\begin{array}{l}\text { No. of } \\
\text { Anclyes }\end{array}$ & $\begin{array}{c}\text { H } \\
\left(0 v^{\circ} \mu \mathrm{u} / \mathrm{m} t\right)\end{array}$ & 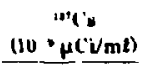 & $\begin{array}{c}\text { Mapu } \\
\text { (10 2 } \mu(\mathrm{U} / \mathrm{m} t)\end{array}$ & 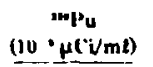 & $(10 \cdot \mu \mathrm{Cim} / \mathrm{ml})$ & $\begin{array}{c}\text { Gross } \alpha \\
(10 \cdot \mu \mathrm{Ci} / \mathrm{m} t)\end{array}$ & $\begin{array}{c}\text { Grosti } \beta \\
\left(10^{-8} \mu(-1 / \mathrm{m} t)\right. \\
\end{array}$ & $\begin{array}{c}\text { Totul U" } \\
\left(\mu y^{\prime} l\right)\end{array}$ \\
\hline \multicolumn{10}{|l|}{ Nomefnuent Areal } \\
\hline Tesit Well I & 1 & $1.0 \pm 11 . \mathrm{i}$ & $34 \pm+1$ & $-611.4 \pm 01.4 \mathrm{i}$ & $\theta(r) \pm \theta w_{1}$ & $\ldots$ & $-111 \pm 1.6$ & $1.2 \pm 1.8$ & $a .0 \pm a N$ \\
\hline Tesi Well 3 & 1 & $-0.1 \pm 0.8$ & $-211 \pm 411$ & $0(n) \pm 0 .(1.1$. & $001 \neq 0.02$ & $\ldots$ & $1+ \pm 1.0$ & $3.2 \pm 12$ & $11 \pm 11 \%$ \\
\hline Deep'Test SA & 3 & $0.4 \pm 1.0$ & $5 \pm 45$ & $-0.13 .6 \pm 0.1 \% 3$ & $-6, w 2 \pm 0.04$ & $\ldots$ & $0.8 \pm 2.2$ & $5.3 \pm 3.6$ & $16 \pm 14$ \\
\hline Test Well 8 & 2 & $0.4 \pm 1.1$ & $11 \pm 28$ & $-61.112 \pm 11.64$ & $-4110 \pm 0.13$ & $\ldots$ & $-0.2 \pm 2.5$ & $2.7 \pm 1.8$ & $112 \pm 11 . \mathrm{s}$ \\
\hline Deep Test 9 & 1 & $0.2 \pm 0.6$ & $-411 \pm 46$ & $-0014 \pm 0.165$ & $-10.112 \pm 0.144$ & $\ldots$ & $2.1 \pm \pm 2.0$ & $3.8 \pm 1.8$ & $\|y \pm\|$ M \\
\hline Deep Teas 10 & $i$ & $-0.1 \pm 0.3$ & $-111 \pm 411$ & $1001 \pm 01010$ & $-10.112 \pm 0.10 \mathrm{ki}$ & $\ldots$ & $0.7 \pm 14$ & $1.3 \pm 1.6$ & א \\
\hline Canadu del Buey & 2 & $2.1 \pm 3.4$ & $-16 \pm i 1$ & $-(1131 \pm 01114$ & $0.011 \pm 0011$ & $\ldots$ & $1.0 \pm 3.7$ & $6.4 \pm 5.2$ & $1: \pm=x$ \\
\hline Pajaritu Canyon & 2 & $2.0 \pm 0.4$ & $15 \pm 71$ & $0 .(x) \pm 11.04$ & $-0.02 \pm 10.013$ & $\ldots$ & $0.6 \pm 0.7$ & $5.11 \pm 1.2$ & $0.3 \pm 0.3$ \\
\hline Water Canyon & 1 & $-0.1 \pm 0.8$ & $111 \pm+10$ & $0.01 \pm 116.1$ & $0.01 \pm 0.04$ & $\ldots$ & $0.5 \pm 1.6$ & $10 \pm 2 . x$ & $0.0 \pm 11 \%$ \\
\hline Test Well 2 & 2 & $0.4 \pm 1.3$ & $11 \pm 54$ & $-10.01 \pm 0.010$ & $0.00 \pm 0.02$ & $\cdots$ & $0.2 \pm 0.7$ & $8.2 \pm 21$ & $0.3 \pm 0.5$ \\
\hline No. of Analywea & & 16 & 16 & 15 & 15 & $\ldots$ & 16 & 16 & 15 \\
\hline Minimum & & $-0.1 \pm 0.8$ & $-40 \pm+11$ & $-0.04 \pm 0.10 .6 \mathrm{i}$ & $-0.0 .43 \pm 0.0 .45$ & $\ldots$ & $-0.1 \pm 1.6$ & $1.3 \pm 1.6$ & $0.0 \pm 0.8$ \\
\hline Maximum & & $3.3 \pm 0.8$ & $411 \pm(x \mid$ & $\|.111 \pm\| .1 \mathrm{ki}$ & $18.02 \pm$ a.14 & $\cdots$ & $2.3 \pm 2.0$ & $16 \pm: 1.6$ & $2.3 \pm 0 . .4$ \\
\hline Averake & & $0.7 \pm 2.0$ & $0 \pm 4 H$ & $-0.01 \pm 0.04$ & $-0.01 \pm 0.1 \mathrm{k3}$ & $\cdots$ & $0.6 \pm 1.9$ & $3.0 \pm 7.5$ & $0.8 \pm 1.6$ \\
\hline \multicolumn{10}{|l|}{$\begin{array}{l}\text { Emuent Heloase Arens } \\
\text { Acid- 'Pueblo Canyon } \\
\text { (former rolowe area) }\end{array}$} \\
\hline Acid Weir & 2 & $1.0 \pm 1.8$ & $-111 \pm 24$ & $0 .(x) \pm 0.1 s i$ & $0.39 \pm 18.62$ & $\cdots$ & $1.9 \pm 1.8$ & $56 \pm 115$ & $0.4 \pm 1.4$ \\
\hline Pueblo 1 & 2 & $0.9 \pm 0.1$ & $: 11 \pm 25$ & $-0.01 \pm 0.002$ & $0.010) \pm 0.018$ & . & $0.7 \pm 1.1$ & $14 \pm 211$ & $0.4 \pm 1.1$ \\
\hline Pueblo 2 & 2 & $1.0 \pm 0.0$ & $11 \pm 2 \pi$ & $v(x) \pm 0.00$ & $0.04 \pm 0.01$ & $\ldots$ & $0.2 \pm 1.0$ & $13 \pm 11$ & $11.2 \pm 114$ \\
\hline Pueblo: & 2 & $0.7 \pm 0.3$ & $3(1) \pm 2 \mathrm{H}$ & $(1.00) \pm 0.14$ & $0.111 \pm 0.0 .15$ & $\ldots$ & $0.5 \pm 3.4$ & $30 \pm 52$ & $0.3 \pm 17$ \\
\hline Hamiltin Bend Spr & 2 & $0.4 \pm 0.7$ & $-4 \pm 13$ & $-0.012 \pm 0.01$ & $0.05 \pm 0 .(1 \mathrm{k}$ & $\ldots$ & $2.1 \pm 2.4$ & $14 \pm 7,9$ & $1.5 \pm 4.2$ \\
\hline Teal Well iA & 2 & $0.6 \pm 1.3$ & $5 \pm 14$ & $-0.01 \pm 0.01$ & $0.131 \pm 0.01$ & $\cdots$ & $0.4 \pm 0.3$ & $7.2 \pm 1.1$ & $0.6 \pm 1.8$ \\
\hline Test Well $2 A$ & 2 & $19 \pm 1.4$ & $0 \pm 28$ & $0.01 \pm 0.01$ & $0.00 \pm 0.03$ & $\cdots$ & $0.4 \pm 0.3$ & $1.7 \pm 0.3$ & $0.0 \pm 0.0$ \\
\hline No. of Anulyne & & 14 & 14 & 14 & 14 & $\ldots$ & 14 & 14 & it \\
\hline Minimum & & $0.2 \pm 0.6$ & $-20) \pm(x)$ & $-0.0 .03 \pm 0.020$ & $-0.01 \pm 0.014$ & $\ldots$ & $-0.7 \pm 1.4$ & $1.6 \pm 16$ & $0.0 \pm 0 . .4$ \\
\hline Maximuin & & $20 \pm 3.0$ & $40 \pm(14)$ & $0.02 \pm 0.013$ & $0.511 \pm 0.14$ & $\cdots$ & $2.6 \pm 2.2$ & $97 \pm 10$ & $3.0 \pm 0.8$ \\
\hline Average & & $3.4 \pm 14$ & $4 \pm 31$ & $0.00) \pm 0.03$ & $0.06 \pm 0.26$ & $\ldots$ & $0.9 \pm 2.0$ & $19 \pm 50$ & $0.5 \pm 1.7$ \\
\hline
\end{tabular}


TABLE E-XIV (Cont)

Hudicushemicul

(average of a number of annlyee)

\begin{tabular}{|c|c|c|c|c|c|c|c|c|c|}
\hline \multirow{2}{*}{ Stution } & \multirow[b]{2}{*}{$\begin{array}{l}\text { No. of } \\
\text { ae tyoes }\end{array}$} & \multirow[b]{2}{*}{ 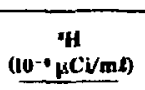 } & \multirow[b]{2}{*}{$\begin{array}{c}\text { "arc } \\
\left(10^{-0} \mu(\mathrm{i} / \mathrm{m} t)\right. \\
\end{array}$} & & & & & & \\
\hline & & & & $\begin{array}{c}-P u \\
(10 \cdot \mu(\mathrm{V} / \mathrm{mL}) \\
\end{array}$ & $\begin{array}{c}m p u \\
(10 \cdot \mu(\mathrm{P} / \mathrm{m} \ell)\end{array}$ & $\begin{array}{c}m A m \\
\left(10^{-1}+\mu \mathrm{Ci} / \mathrm{ml}\right)\end{array}$ & 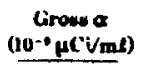 & $\begin{array}{c}\text { Grows } \beta \\
\left(10^{-1} \mu\left(V_{m b}\right)\right.\end{array}$ & $\begin{array}{c}\text { Tutul } 11 \\
(\mu \nu / l) \\
\end{array}$ \\
\hline \multicolumn{10}{|c|}{ DP-Las Alamos Canyon } \\
\hline DPS.1 & 2 & $3.2 \pm 10.3$ & $24 \pm 16$ & $18.18 \pm \pm 0.10$ & $0.39 \pm 10.71$ & $7.6 \pm 0.80$ & $27 \pm 9.9$ & $218 \pm 119$ & $\pi 19$ \\
\hline UPSi-4 & 2 & $9.3 \pm 4.5$ & $10 \pm 2 \mathrm{M}$ & $0.04 \pm 0.03$ & $0.22 \pm 0.24$ & $1.6 \pm 0.24$ & $5.5 \pm 1.4$ & $360 \pm 5 i$ & $6.4 \pm 7.9$ \\
\hline I.AO.C & 2 & $1.5 \pm 2.3$ & $11 \pm 25$ & $-1.01 \pm 0.05$ & $10.115 \pm 0.14$ & $0.199 \pm 0.12$ & $1.1 \pm 2.1$ & $4.2=8.5$ & $1.0 \pm 2.4$ \\
\hline L.AC).1 & 2 & $3.8 \pm 7.8$ & $t \pm 17$ & $0.00) \pm 0.01$ & $0.0103 \pm 0.012$ & $-0.02 \pm 0.08$ & $0.2 \pm 0.4$ & $55 \pm 140$ & $0.3 \pm 0.7$ \\
\hline LAO).2 & 2 & $8.2 \pm 6.9$ & $14 \pm 11$ & $0.03\} \pm 0.103$ & $0.12 \pm 0.07$ & $0.97 \pm 0.16$ & $3.4 \pm 1.7$ & $245 \pm 127$ & $1.8 \pm 2.4$ \\
\hline LAOB-3 & 2 & $7.6 \pm 10$ & $-i \pm 28$ & $0.01 \pm 0.01$ & $0.03 \pm 0.033$ & $0.25 \pm 0.12$ & $3.8 \pm 3.5$ & $112 \pm 117$ & $1.2 \pm 3.4$ \\
\hline LAO).4 & 2 & $3.2 \pm 0.6$ & $-15 \pm+2$ & $0.00 \pm 10.106$ & $0.06 \pm 0.01$ & $0.23 \pm 0.14$ & $1.3 \pm 2.3$ & $22 \pm 7.1$ & $0.6 \pm 0.1$ \\
\hline LA(1).4.5 & 2 & $4.3 \pm 0.0$ & $15 \pm 42$ & $-0.01 \pm 01.0 .3$ & $0.01 \neq 0.01$ & $0.16 \pm 0.10$ & $2.5 \pm 3.0$ & $13 \pm 12$ & $1.2 \pm 1.6$ \\
\hline Nor, of Analywes & & 16 & 16 & 16 & 16 & $B$ & 16 & $16 \mathrm{i}$ & $16 \mathbf{i}$ \\
\hline Minimum & & $0.7 \pm 0.6$ & $-i n+ \pm \mathbf{m o}$ & $-0.122 \pm 11.144$ & $-0.111 \pm 0.06$ & $-0.02 \pm 0.00$ & $0.0 \pm 1.8$ & $1.2 \pm 1.6$ & $0.0 \pm 0.8$ \\
\hline Maximum & & $11.2 \pm 1.4$ & : $1 \pm$ & $0.11 \pm 11.04$ & $0.64 \pm 0.18$ & $7.6 \pm 0.80$ & $30 \pm 14$ & 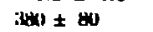 & $\pi \pm 1: 3$ \\
\hline Average & & $5.2 \pm 6.8$ & $i \pm 32$ & $0.012 \pm 0.07$ & $0.11 \pm 0.32$ & $1.4 \pm 5.2$ & $5.5 \pm 17$ & $127 \pm \div 1$ & $10 \pm t k$ \\
\hline \multicolumn{10}{|l|}{ Sandin Cenvoe } \\
\hline SCs.1 & 2 & $5.8 \neq 0.7$ & $15 \pm 14$ & $0.0 .81 \pm 0.11$ & $0.01 \pm 0.01$ & $-0.01 \pm 0.10$ & $0.4 \pm 0.7$ & $25 \pm 2.8$ & $1.9 \pm 11.1$ \\
\hline scs:-2 & 2 & $7.2 \pm 1.7$ & $i \pm: 17$ & $-0.01 \pm 0.1 .12$ & $0.00 \pm 0.02$ & $0.01 \pm 0.12$ & $0.4 \pm 1.3$ & $16 \pm 8.1$ & $1.8 \pm 0.5$ \\
\hline scs.; & 2 & $6.5 \pm 0.7$ & + \pm 6 & $0.00 \pm 0.030$ & $0.00 \pm 0.02$ & $0.03 \neq 0.08$ & $1.1 \pm 0.4$ & $16 \pm 12$ & $1.4 \pm 1.3$ \\
\hline Now, or Arsalyem & & 6 & ij & 6 & 6 & 3 & 6 & 6 & 6 \\
\hline Minimum & & $5.5 \pm 0.8$ & $-27) \pm(20$ & $-10.02 \pm 10.12\}$ & $-0.01 \pm 0.04$ & $-0.01 \neq 0.10$ & $0.2 \pm 3.8$ & $12 \pm 2.8$ & $1.0 \pm 11.8$ \\
\hline Marimum & & $7.5 \pm 1.2$ & $27 \pm 24$ & $0.07 \pm 0.016$ & $0.01 \pm 0.02$ & $0.03 \pm 0.08$ & $1.3 \pm 2.0$ & $26 \pm 6$ & $2.0 \pm 11.4$ \\
\hline Average & & $6.5 \pm 1.4$ & $B \pm 36$ & $0.01 \pm 0.06$ & $0.00 \pm 0.02$ & $0.01 \neq 0.04$ & $0.7 \pm 1.0$ & $19 \pm 11$ & $1.7 \pm 0.7$ \\
\hline \multicolumn{10}{|l|}{ Mortanded Canyon } \\
\hline GS-1 & 2 & $307 \pm 913$ & $(24) \pm 2,56$ & $2.70 \pm 1.70$ & $1.64 \pm 2.45$ & $1.27 \pm 0.32$ & $8.9 \pm 17$ & $203 \pm=3848$ & $0.8 \pm 11.7$ \\
\hline $\mathrm{MCO}-3$ & 2 & $49 \pm 7: 1$ & $15 \pm$ i4 & $2.42 \pm 1.22$ & $0.26 \pm 0.69$ & $0.70 \neq 0.40$ & $12 \pm 8.5$ & $+2 \pm 364$ & $1.9 \pm: 1.3$ \\
\hline$M(O) \cdot 4$ & 2 & $95 \pm 72$ & $-15, \pm \pi 1$ & $0.26 \pm 0.18$ & $0.10 \pm 0.26$ & $5.6 \pm 0.60$ & $24 \pm 2.8$ & $104 \pm 2215$ & $2.8) \pm 1.3$ \\
\hline MCO.5 & 2 & $68 \pm 4.5$ & $0 \pm 57$ & $1.32 \pm 6.24$ & $0.25 \pm 0.65$ & $1.6 \pm 0.24$ & $16 \pm 4.2$ & $60 \pm 75$ & $3.0 \pm .8 .8$ \\
\hline MCO-6 & 2 & $51 \pm 60$ & $10 \pm 58$ & $0.19 \pm 18.189$ & $0.04 \pm 0.01$ & $0.48 \pm 0.20$ & $11 \pm 17$ & $27 \pm 32$ & $3.0 \pm 2.7$ \\
\hline M(O). 7 & 2 & $75 \pm 6.5$ & $-11 \pm 27$ & $10.19 \pm 11.01$ & $0.06 \pm 0.03$ & $0.01 \neq 0.22$ & $16 \pm 18$ & $30 \pm 8.5$ & $3.8 \pm 13$ \\
\hline MCO-7.5 & 2 & $113 \pm 104$ & $i \pm 10: 3$ & $0.23 \pm 10.06$ & $0.07 \pm 0.14$ & $-0.40 \neq 1.0$ & $27 \pm 54$ & $35 \pm 32$ & $3.1 \pm \times .1$ \\
\hline 10-Site Canyon & 1 & $3.7 \pm 0.8$ & $2 \pm 18$ & $0.04 \div+1.06$ & $0.01 \pm 0.03$ & $\ldots$ & $1.8 \pm 1.4$ & $15 \pm 3.4$ & $1.1 \pm 10.8$ \\
\hline No. of Analyoes & & 15 & 15 & is & 15 & 7 & 15 & 15 & is \\
\hline Minimum & & $3.7 \pm 0.8$ & $-411 \pm 6(1)$ & $0.104 \pm 11.040 j$ & $0.01 \pm 0.06$ & $-0.40 \pm 1.0$ & $1.8 \pm 1.4$ & $15 \pm 3.4$ & $0.5 \pm 11.8$ \\
\hline Maximum & & $650 \pm 20$ & $210 \pm 40$ & $4.1 i^{2} \pm 0.34$ & $2.51 \pm 0.24$ & $5.6 \pm 0.60$ & $46 \pm 20$ & $340 \pm 60$ & $+.3 \pm 11.8$ \\
\hline Average & & $104 \pm 312$ & $17 \pm 117$ & $0.94 \pm 2.88$ & $0.19 \pm 0.50$ & $1.3 \pm 4.0$ & $15 \pm 22$ & $68 \pm 171$ & $2.9 \pm 4.7$ \\
\hline
\end{tabular}


TABLE' E-XIV (Cont)

(concentrations in my/l. one anulywis)

\begin{tabular}{|c|c|c|c|c|c|c|c|c|c|c|c|c|c|c|c|c|}
\hline Station & SiO, & Ca & $\mathbf{M E}$ & $\mathbf{K}$ & $\mathrm{Na}$ & co, & HCO. & PO. & so. & $c e$ & $\mathbf{F}$ & No, & Tos & Hard & pH & $\begin{array}{c}\text { Cond } \\
(\mathrm{mS} / \mathrm{m})\end{array}$ \\
\hline \multicolumn{17}{|l|}{ Nonemuent Areas } \\
\hline Teat Well 1 & 26 & 32 & 2 & 4.0 & 21 & 0 & 151 & 0.1 & 2 & 13 & 1.5 & 1 & 186 & 85 & 8.4 & 24 \\
\hline Deefr'test 5A & 50 & 3 & 2 & 2.7 & $\underline{1}$ & 0 & $7 \mathfrak{b}$ & 1.0 & 2 & 2 & 0.3 & 3 & 180 & 33 & 84 & $1: 3$ \\
\hline "Test Well 8 & 76 & 4 & 1 & 18 & 11 & 0 & 44 & 1.0 & 1 & 2 & 02 & 1 & 54 & 70 & 9.7 & 7 \\
\hline Deep Teat 9 & 40 & 5 & 3 & 1.0 & 11 & 0 & 27 & 1.0 & 2 & 2 & 174 & 2 & 138 & 35 & 8.3 & 10 \\
\hline Deep Test II) & 58 & 6 & 3 & 1.4 & 11 & 0 & Bo & 2.0 & 1 & 2 & 10.4 & 1 & 130 & 50 & 8.5 & 12 \\
\hline Canada del Huey & 58 & 3 & 2 & 1.9 & b & 3 & 22 & 10 & $\dot{b}$ & 3 & 07 & 1 & 78 & 10 & 7.6 & 3 \\
\hline Pajarito Canyon & 15 & 7 & 4 & 3.3 & 15 & 3 & 56 & (1). 1 & 14 & 17 & (1).2 2 & 3 & 192 & 5.5 & 8.2 & 16 \\
\hline Test Well 2 & 26 & 7 & 3 & 1.1 & 9 & 0 & 83 & $<0.1$ & 2 & 2 & 0.4 & 2 & 172 & 55 & 8.4 & 12 \\
\hline No. of Analyses & 8 & 8 & 8 & 8 & 8 & 8 & 8 & 8 & 8 & 8 & 8 & 8 & 8 & 8 & 8 & 8 \\
\hline Minimum & 15 & 3 & 1 & 1.0 & is & 0 & 22 & $<0.1$ & 1 & 2 & 0.2 & 1 & 54 & 10 & 7.6 & 3 \\
\hline Maximum & 76 & 32 & 4 & 4.0 & 21 & 3 & $|5|$ & 2.0 & 14 & 17 & 0.7 & 3 & 192 & 85 & 9.7 & 24 \\
\hline Averase & $14 \pm 41$ & $8 \pm 19$ & $3 \pm 2$ & $2.2 \pm 2.2$ & $1: 2 \pm 11$ & $<1 \pm 3$ & $67 \pm 82$ & $0.8 \pm 1.3$ & $4 \pm 9$ & $5 \pm 1: 2$ & $0.4 \pm 0.3$ & $2 \pm 2$ & $141 \pm 104$ & $49 \pm 47$ & $8.4 \pm 1.2$ & $12 \pm 12$ \\
\hline
\end{tabular}

\section{Eitiuapt Rolomes Areas
Acid-Pueblo Canyon}

Armer releave areas

Acid Weir

Pueblo 1

Pueblo 2
Pueblo 3

Hamilon Bend Spr

Test Well iA

Teat Well $2 A$

\section{No. of Anulyze:}

Minimum

Maximum

Average

66
20
34
34
34
10
4
7
4
66
$29 \pm 41$

$\begin{array}{rll}11 & 2 & 4.4 \\ 9 & 3 & 5.4 \\ 8 & 2 & 4.7 \\ 9 & 3 & 7.1 \\ 8 & 4 & 7.3 \\ 9 & 3 & 6.2 \\ 16 & 4 & 2.5 \\ 7 & 7 & 7 \\ 7 & 2 & 2.5 \\ 8 & 4.5 \\ 16 & 4 & 7.3 \\ 10 \pm 6 & 3 \pm 2 & 5.4 \pm 3.3\end{array}$

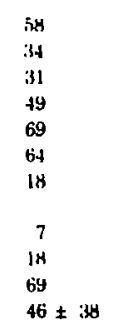

$\begin{array}{lc}0 & 71 \\ 0 & 90 \\ 0 & 71 \\ 0 & 88 \\ 0 & 110 \\ 0 & 132 \\ 0 & 49 \\ & 7 \\ 7 & 7 \\ 0 & 49 \\ \cdots & 132 \\ \cdots & 87 \pm 55\end{array}$
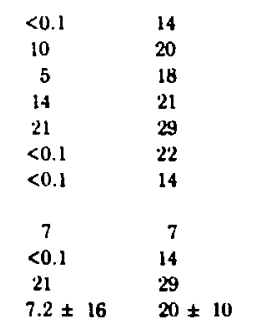

$\begin{array}{ll}61 & 0.5 \\ 20 & 0.3 \\ 22 & 0.3 \\ 30 & 0.5 \\ 40 & 0.9 \\ 38 & 0.8 \\ 28 & 0.2 \\ & \\ 7 & 7 \\ 20 & 0.2 \\ 61 & 0.9 \\ 34 \pm 28 & 0.5 \pm 0.5\end{array}$

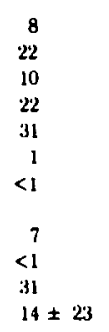

$\begin{array}{clll}276 & \mathbf{4 5} & 8.3 & 37 \\ 258 & \mathbf{4 5} & 8.3 & 25 \\ 222 & 45 & 8.3 & 22 \\ 292 & 90 & 8.2 & 16 \\ 370 & 50 & 8.0 & 42 \\ 290 & 40 & 8.7 & 38 \\ 92 & \mathbf{4 5} & \mathbf{9 . 0} & 17 \\ & & & \\ 7 & 7 & 7 & 7 \\ 92 & 40 & 8.0 & 16 \\ 370 & \mathbf{9 0} & \mathbf{9 . 0} & \mathbf{4 2} \\ 257 \pm 171 & \mathbf{5 1} \pm 35 & \mathbf{8 . 4} \pm 0.7 & 28 \pm 21\end{array}$

\begin{tabular}{|c|c|}
\hline $\begin{array}{l}\text { DP-Lan Alemo Cenyon } \\
\text { DPSS-1 } \\
\text { DPS-4 } \\
\text { LAO-C } \\
\text { LAO.1 } \\
\text { LAO.2 } \\
\text { LAO-3 } \\
\text { LAO.4 } \\
\text { LAO-4.5 }\end{array}$ & 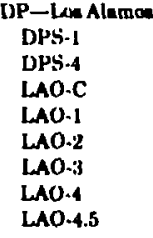 \\
\hline & $\begin{array}{l}\text { No. of Analyses } \\
\text { Mininium } \\
\text { Maximum } \\
\text { Averase }\end{array}$ \\
\hline
\end{tabular}

$\begin{array}{rccr}43 & 5 & 8.9 & 12: 1 \\ 10 & 2 & 24 & 130 \\ 6 & 3 & 2.9 & 21 \\ 8 & 3 & 3.4 & 31 \\ 13 & 3 & 25 & 129 \\ 22 & 5 & 33 . & 117 \\ 12 & 5 & 6.9 & 47 \\ 13 & 6 & 5.0 & 46\end{array}$

$12: 3$
130
211
31
129
117
47
46 8
6
+14

8
6
$4: 3$
$16 \pm 24$

$\begin{array}{rrr}173 & <0.1 & 46 \\ 178 & <0.1 & 18 \\ 49 & <0.1 & 9 \\ 58 & <0.1 & 11 \\ 151 & <0.1 & 29 \\ 156 & <0.1 & 33 \\ 71 & <0.1 & 17 \\ 112 & 5.0 & 19\end{array}$

$\begin{array}{rrr}127 & \mathbf{4} .0 & 21 \\ 72 & 10.0 & \mathbf{8 0} \\ 30 & 0.1 & 1 \\ 36 & 0.2 & 1 \\ 76 & 6.4 & 89 \\ \mathbf{9 0} & 2.3 & \mathbf{9 8} \\ 51 & 1.0 & 9 \\ 39 & 0.5 & 7\end{array}$

21
80
1
1
89
98
9
7
8
1
94
$38 \pm 86$

$\begin{array}{lr}580 & 145 \\ 558 & 30 \\ 154 & 25 \\ 200 & 45 \\ 560 & 55 \\ 536 & 95 \\ 236 & 60 \\ 182 & 65\end{array}$

$\begin{array}{rrr}145 & 8.7 & 80 \\ 30 & 8.6 & 70 \\ 25 & 8.0 & 18 \\ 45 & 8.4 & 24 \\ 55 & 8.7 & 72 \\ 95 & 8.4 & 72 \\ 60 & 8.4 & 34 \\ 65 & 8.5 & 38\end{array}$

8
154 
TABLE E-XV

\section{LOCATION OF SOIL AND SEDIMENT STATIONS}

\begin{tabular}{|c|c|c|c|}
\hline Station & $\begin{array}{c}\text { Latitude } \\
\text { or } \\
\text { N-S } \\
\text { Coordinate }\end{array}$ & $\begin{array}{c}\text { Longitude } \\
\text { or } \\
\text { E-W } \\
\text { Coordinate }\end{array}$ & $\begin{array}{l}\text { Map } \\
\text { Degignation } \\
\text { (Figure 13) }\end{array}$ \\
\hline
\end{tabular}

\section{Reglonal Soils ${ }^{b}$}

Regional Sediments
Rio Chama
Chamita
Rio Grande
Embudo
Otowi
Sandia
Pajarito
Ancho
Frijoles
Cochiti
Bernalillo

$\begin{array}{lll}36^{\circ} 05^{\prime} & 106^{\circ} 07^{\prime} & \ldots \\ 36^{\circ} 12^{\prime} & 105^{\circ} 58^{\prime} & \ldots \\ \text { N085 } & \text { E550 } & \text { A } \\ \text { S060 } & \text { E490 } & \text { B } \\ \text { S185 } & \text { E410 } & \text { C } \\ \text { S305 } & \text { E335 } & \text { D } \\ \text { S375 } & \text { E235 } & \text { E } \\ 35^{\circ} 37^{\prime} & 106^{\circ} 19^{\prime} & \ldots \\ 35^{\circ} 17^{\prime} & 106^{\circ} 36^{\prime} & \ldots \\ 35^{\circ} 40^{\prime} & 106^{\circ} 44^{\prime} & \ldots\end{array}$

Perimeter Soils

Sportsman's Club

N240

E215

S1

TA-8

N060

TA-49

S165

W075

S2

Frijoles

S245

North Mesa

East of Airport

West of Airport

South SR-4 near S-Site

N135

E085

S3

$\mathrm{S} 4$

S5

N095

E180

S6

N115

E220

E135

S085

W035

S7

S8

\section{Perimeter Sediments}

Guaje near G-4

N215

Guaje at SR-4

N135

Bayo at SR-4

N100

Pueblo at Acid Weir

N125

Pueblo at PC-1

N130

Pueblo at Pueblo 1

N130

Pueblo at Pueblo 2

N120

Los Alamos at Reservoir

N100

Los Alamos at Totavi

N065

Los Alamos at LA-2

Los Alamos at Rio Grande

$\mathrm{N} 125$

No95

Sandia at Rio Grande

Canada del Ancha

Mortandad at SR-4

Mortandad at Rio Grende

Canada del Buey at SR-4

S055

S060

S030

S075

Pajarito at Rio Grande

S090

Frijoles at Park Hdq

$\mathrm{S} 175$

Frijoles at Rio Grande

$\begin{array}{ll}\text { E325 } & 1 \\ \text { E480 } & 2 \\ \text { E455 } & 3 \\ \text { E070 } & 4 \\ \text { E070 } & 5 \\ \text { E085 } & 6 \\ \text { E145 } & 7 \\ \text { W065 } & 8 \\ \text { E405 } & 9 \\ \text { E510 } & 10 \\ \text { E555 } & 11 \\ \text { E490 } & 12 \\ \text { E505 } & 13 \\ \text { E350 } & 14 \\ \text { E480 } & 15 \\ \text { E360 } & 16 \\ \text { E410 } & 17 \\ \text { E185 } & 18 \\ \text { E235 } & 19\end{array}$




Station

\section{Onsite Soils}

TA-21

TA-50

TA -36

PM-1

West of TA-53

East of TA-53

East of New Sigma

Sigma Mesa

East of TA-52

2-Mile Mesa

Near TA-51

East of TA-54

R-Site Road

R-Site Road East

Potrillo Drive

S-Site

Near TA-11

Near DT-9

TA-3.3

\section{Onsite Sediments}

Pueblo at Hamilton Bend Spr

Pueblo at Pueblo 3

Pueblo at SR-4

DP Canyon at DPS-1

DP Canyon at DPS-4

Los Alamos Canyon at Bridge

Los Alamos at LAO-1

Los Alamos at GS-1

Los Alamos at TW-3

Los Alamos at LAO-4

Los Alamos at SR-4

Sandia at SCS-2

Sandia at SR-4

Mortandad near CMR

Mortandad West of GS-1

Mortandad Near MCO-2

Mortandad at GS.1

Mortandad at MCO-5

Mortandad at MCO-7

Mortandad at MCO-9

Mortandad at MCO-13

Pajarito at TA-18

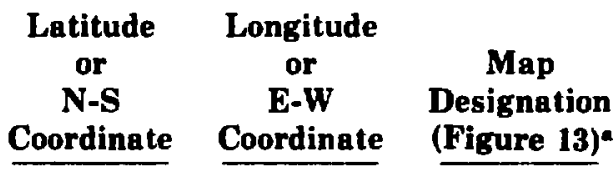

$\begin{array}{lll}\text { N095 } & \text { E140 } & \text { S9 } \\ \text { N035 } & \text { E095 } & \text { S10 } \\ \text { S090 } & \text { E150 } & \text { S11 } \\ \text { N020 } & \text { E310 } & \text { S12 } \\ \text { N070 } & \text { E105 } & \text { S13 } \\ \text { N050 } & \text { E220 } & \text { S14 } \\ \text { N060 } & \text { E065 } & \text { S15 } \\ \text { N050 } & \text { E135 } & \text { S16 } \\ \text { N020 } & \text { E145 } & \text { S17 } \\ \text { N025 } & \text { E030 } & \text { S18 } \\ \text { S030 } & \text { E200 } & \text { S19 } \\ \text { S080 } & \text { E295 } & \text { S20 } \\ \text { S015 } & \text { E030 } & \text { S21 } \\ \text { S040 } & \text { E100 } & \text { S22 } \\ \text { S065 } & \text { E195 } & \text { S23 } \\ \text { S035 } & \text { W025 } & \text { S24 } \\ \text { S070 } & \text { E020 } & \text { S25 } \\ \text { S150 } & \text { E140 } & \text { S26 } \\ \text { S245 } & \text { E225 } & \text { S27 }\end{array}$

$\mathrm{N} 105$

N090

N070

N090

N075

N095

N080

N075

N075

N075

N065

N050

N025

N060

N045

N035

N040

N035

N025

N030

N015

S055

$\begin{array}{ll}\text { E255 } & 20 \\ \text { E315 } & 21 \\ \text { E350 } & 22 \\ \text { E160 } & 23 \\ \text { E205 } & 24 \\ \text { E020 } & 25 \\ \text { E120 } & 26 \\ \text { E200 } & 27 \\ \text { E215 } & 28 \\ \text { E240 } & 29 \\ \text { E355 } & 30 \\ \text { E175 } & 31 \\ \text { E315 } & 32 \\ \text { E036 } & 33 \\ \text { E095 } & 34 \\ \text { E090 } & 35 \\ \text { E105 } & 36 \\ \text { E155 } & 37 \\ \text { E190 } & 38 \\ \text { E215 } & 39 \\ \text { E250 } & 40 \\ \text { E195 } & 41\end{array}$

S9

S10

S12

S13

S14

$\mathrm{S} 15$

S16

S17

S19

S20

S21

S22

S23

S24

S26

S27

\section{0}

21

22

23

24

25

26

27

28

29

30

31 
TABLE E-XV (Cont)

\begin{tabular}{lcccc}
\multicolumn{1}{c}{ Station } & $\begin{array}{c}\text { Latitude } \\
\text { or } \\
\text { N-S }\end{array}$ & $\begin{array}{c}\text { Longitude } \\
\text { or } \\
\text { Coordinate }\end{array}$ & $\begin{array}{c}\text { E-W } \\
\text { Coordinate }\end{array}$ & $\begin{array}{c}\text { Map } \\
\text { Designation } \\
\text { (Figure 13) }\end{array}$ \\
\cline { 1 - 2 } Pajarito at SR-4 & S105 & & E320 & \\
Potrillo at TA-36 & S075 & & E150 & 42 \\
Potrillo East of TA-36 & S085 & & E225 & 44 \\
Potrillo at SR-4 & S145 & & E295 & 45 \\
Water at Beta Hole & S090 & & E095 & 46 \\
Water at SR-4 & S170 & & E260 & 47 \\
Water at Rio Grande & S240 & E385 & 48 \\
Ancho at SR-4 & S255 & E250 & 49 \\
Ancho at Rio Grande & S295 & E340 & 50 \\
Chaquihui at Rio Grande & S335 & E265 & 51
\end{tabular}

-See Fig. 13 for numbered locations.

'Locations are the same as for surface water stations (Table E-X). 
TABLE E-XVI

RADIOCHEMICAL ANALYSES OF REGIONAL SUILS AND SFIMIMF'T':

\begin{tabular}{|c|c|c|c|c|c|c|c|c|c|}
\hline & $\begin{array}{c}{ }^{\mathrm{H}} \\
\left(10^{-} \cdot \mu \mathrm{Ci} / \mathrm{m} \ell\right) \\
\end{array}$ & $\begin{array}{c}{ }^{n} \mathrm{Cs} \\
(\mathrm{pCi} / \mathrm{s})\end{array}$ & $\begin{array}{c}{ }_{2 s+P u} \\
(\mathrm{pCi} / \mathrm{s})\end{array}$ & $\begin{array}{r}{ }^{2 n} \mathrm{Pu} \\
(\mathrm{pCi} / \mathrm{g})\end{array}$ & $\begin{array}{c}\begin{array}{c}\infty \mathrm{Sr} \\
(\mathrm{pCi} / \mathrm{s})\end{array} \\
\end{array}$ & $\begin{array}{c}{ }^{\mathrm{N}} \mathrm{Am} \\
(\mathrm{pCi} / \mathbf{s}) \\
\end{array}$ & $\begin{array}{l}\text { Grous a } \\
\text { (pciv/g) }\end{array}$ & $\begin{array}{l}\text { Grose } \beta \\
(\mathrm{pCi} / \mathrm{s}) \\
\end{array}$ & $\begin{array}{r}\text { Total U } \\
(\mu \mathbb{E}) \\
\end{array}$ \\
\hline \multicolumn{10}{|l|}{ Regional Soile } \\
\hline Chamita & $1.3 \pm 0.6$ & $0.82 \pm 0.14$ & $0.600 \pm 0.003$ & $0.142 \pm 0.1116$ & $0.44 \pm 0.16$ & $0.022 \pm 0.006$ & $5.4 \pm 2.4$ & $8.1 \pm 1.8$ & $2.3 \pm 0.4$ \\
\hline Embudo & $0.6 \pm 0.6$ & $0.88 \pm 0.18$ & $0.000 \pm 0.004$ & $0.0120) \pm 0.006$ & $0.26 \pm 0.14$ & $0.003 \pm 0.008$ & $11 \pm 4.0$ & $12 \pm 2.6$ & $3.3 \pm 0.6$ \\
\hline Otowi & $1.5 \pm 0.6$ & $0.96 \pm 0.18$ & $-0.0002 \pm 0.004$ & $0.02: 3 \pm 0.010$ & $0.40 \pm 0.16$ & $0.011 \pm 0.006$ & $8.1 \pm 3.8$ & $13 \pm 2.8$ & $4.1 \pm 0.8$ \\
\hline Cochiti & $0.8 \pm 0.6$ & $0.25 \pm 0.12$ & $-0.001 \pm 0.003$ & $0 .(K) ; 3 \pm 0.0(0) 4$ & $0.10 \pm 0.10$ & $0.004 \pm 0.003$ & $7.8 \pm 3.6$ & $9.8 \pm 2.2$ & $2.8 \pm 0.6$ \\
\hline Bernalillo & $1.9 \pm 0.6$ & $0.56 \pm 0.12$ & $0.000 \pm 0.0022$ & $0.010 \pm 0.0088$ & $0.18 \pm 0.10$ & $0.002 \pm 0.004$ & $4.8 \pm 2.6$ & $6.0 \pm 1.6$ & $2.1 \pm 0.4$ \\
\hline Jemez & $0.0 \pm 0.6$ & $0.33 \pm 0.14$ & $-0.001 \pm 0.0002$ & $0.005 \pm 0.104$ & $0.17 \pm 0.14$ & $0.001 \pm 0.004$ & $3.3 \pm 1.0$ & $4.1 \pm 1.2$ & $2.0 \pm 0.4$ \\
\hline No. of Analyyes & 6 & 6 & 6 & $\mathbf{6}$ & 6 & 6 & 6 & 6 & 6 \\
\hline Minimum & $0.0 \pm 0.6$ & $0.25 \pm 0.12$ & $-0 .(0) 2 \pm 0 .(x) 4$ & $(0.0 \times) 3 \pm 0.004$ & $0.10 \pm 0.10$ & $0.001 \pm 0.006$ & $3.3 \pm 1.0$ & $4.1 \pm 1.2$ & $2.0 \pm 0.4$ \\
\hline Maximum & $1.9 . \pm 0.6$ & $0.96 \pm 0.18$ & $0.000 \pm 0.004$ & $0.142 \pm 0.016$ & $0.44 \pm 0.16$ & $0.011 \pm 0.006$ & $11 \pm 4.0$ & $13 \pm 2.8$ & $4.1 \pm 0.8$ \\
\hline Averagse & $1.0 . \pm 1.4$ & $0.63 \pm 0.60$ & $-0.001 \pm 0.002$ & $0.034 \pm 0.107$ & $0.26 \pm 0.27$ & $0.004 \pm 0.007$ & $6.7 \pm 5.6$ & $8.8 \pm 6.9$ & $2.8 \pm 1.6$ \\
\hline \multicolumn{10}{|c|}{ Regional River Sediments } \\
\hline \multicolumn{10}{|c|}{ Rio Chame } \\
\hline Chamita• & $\cdots$ & $0.05 \pm 0.11$ & $-0.001 \pm 0.004$ & $(f .(x) \pm 0 .(x)]$ & $-0.15 \pm 0.18$ & $\cdots$ & $1.0 \pm 1.4$ & $1.6 \pm 2.8$ & $1.1 \pm 0.2$ \\
\hline \multicolumn{10}{|l|}{ Hio Grande } \\
\hline Embudo* & $\cdots$ & $0.24 \pm 0.20$ & $-0.002 \pm 0.014$ & $0.0014 \pm(0014$ & $-0.07 \pm 0.14$ & $\cdots$ & $4.7 \pm 2.8$ & $3.6 \pm 1.1$ & $3.0 \pm 0.6$ \\
\hline Otowi* & $\cdots$ & $0.11 \neq 0.04$ & $0.000 \pm 0.002$ & $0.023 \pm \pm 0.1145$ & $0.12 \pm 0.18$ & $\cdots$ & $3.0 \pm 1.3$ & $6.0 \pm 1.7$ & $2.7 \pm 0.6$ \\
\hline Sandia & $\cdots$ & $0.17 \pm 0.06$ & $0.000 \pm 0.000$ & $0 .(5) 4 \pm 0 .(60)$ & $-0.01 \pm 0.13$ & $\cdots$ & $3.3 \pm 1.6$ & $3.6 \pm 0.6$ & $2.2 \pm 0.4$ \\
\hline Pajarito & $\cdots$ & $0.08 \pm 0.10$ & $0.000) \pm 0.000$ & $0.001 \pm 0.0000$ & $0.01 \pm 0.22$ & $\cdots$ & $6.2 \pm 1.4$ & $2.6 \pm 0.8$ & $1.9 \pm 0.4$ \\
\hline Ancho & $\cdots$ & $0.32 \pm 0.10$ & $0.000 \pm 0.000$ & $0.0(1 \mathrm{H}) \pm 0.0 \times(\mathrm{N})$ & $2.5 \pm 0.40$ & $\cdots$ & $6.3 \pm 1.3$ & $6.6 \pm 1.6$ & $2.9 \pm 0.4$ \\
\hline Frijules & $\cdots$ & $0.12 \pm 0.06$ & $0.000 \pm \pm 0 .(100)$ & $0 .(x) 2 \pm 0.000$ & $-0.16 \pm 0.20$ & $\cdots$ & $3.9 \pm 0.9$ & $2.6 \pm 1.0$ & $2.2 \pm 0.4$ \\
\hline Cochiti & $\cdots$ & $0.29 \pm 0.10$ & $0.001 \pm 0.0104$ & $0.0892 \pm 0.010$ & -.. & $\cdots$ & $13 \pm 6.0$ & $16 \pm 3.2$ & $2.8 \pm 0.6$ \\
\hline Bernalillo & $\ldots$ & $0.16 \pm 0.10$ & $-0.001 \pm 0.003$ & $0 .(K) 4 \pm 0.010$ & $\cdots$ & $\cdots$ & $7.3 \pm 3.4$ & $7.3 \pm 3.4$ & $6.8 \pm 1.6$ \\
\hline Jemez Kiver & & $0.16 \pm 0.10$ & $0.000) \pm 0.000$ & $0 .(x) 2 \pm 0.000$ & $-\cdots$ & $\cdots$ & $\ldots$ & ... & -. \\
\hline Jemez Pueblo & $\cdots$ & $0.14 \pm 0.06$ & $-0.001 \pm 0.004$ & $-0.601 \pm 0.003$ & $\ldots$ & $\cdots$ & $8.0 \pm 4.0$ & $6.3 \pm 1.6$ & $2.8 \pm 0.6$ \\
\hline No. of Analyaes & & 13 & 13 & 13 & 7 & $\cdots$ & 13 & 13 & 13 \\
\hline Minimum & & $0.01 \pm 0.10$ & $-0.005 \pm 0.006$ & $-0 .(x) 1 \pm 0.0003$ & $-0.15 \pm 0.18$ & $\cdots$ & $0.5 \pm 0.6$ & $0.6 \pm 0.6$ & $0.9 \pm 0.2$ \\
\hline Maximum & & $0.32 \pm 0.10$ & $0.001 \pm 0.004$ & $0.0339 \pm 0.008$ & $2.5 \pm 0.40$ & $\cdots$ & $13 \pm 6.0$ & $15 \pm 3.2$ & $3.2 \pm 0.6$ \\
\hline Avorage & & $0.16 \pm 0.38$ & $0.000 \pm 0.006$ & $0.008 \pm 0.050$ & $0.32 \pm 1.9$ & $\cdots$ & $4.7 \pm 6.6$ & $4.8 \pm 6.9$ & $2.4 \pm 3$ \\
\hline
\end{tabular}

\section{Two anulywes.}

Note: Value represents twice the standard deviations of the distribution of abserved values unless only one analywis is reported, then the value represents twice the uncertainty term for that analysis. 
TABLEE E-XVII

RADIOCHEMICAL ANALYSES OF PERIMETEH SULLS AND SH:DIMINTS

\begin{tabular}{|c|c|c|c|c|c|c|c|c|}
\hline Station & $\begin{array}{c}{ }^{\cdot H} \\
\left(10^{-} \cdot \mu \mathrm{e} / \mathrm{mol}\right)\end{array}$ & 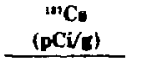 & $\begin{array}{c}\infty \mathrm{sir} \\
(\mathrm{pCi} / \mathrm{g})\end{array}$ & $\begin{array}{c}20 \mathrm{Pu} \\
(\mathrm{p}(\mathrm{V} / \mathrm{g})\end{array}$ & $\begin{array}{c}\text { mpu } \\
(\mathrm{DCi} / \mathrm{s})\end{array}$ & $\begin{array}{l}\text { Grosen } \alpha \\
\text { (pCV/c) }\end{array}$ & $\begin{array}{l}\text { Growes } \\
(\mathrm{DCl} / \mathrm{C})\end{array}$ & $\begin{array}{l}\text { Tounl U } \\
(n+/(0)\end{array}$ \\
\hline \multicolumn{9}{|l|}{ Soils } \\
\hline Spurtsman Club & $0.5 \pm 0.6$ & $1.01 \pm 0.22$ & $\ldots$ & $-0.004 \pm 0.004$ & $0.024 \pm 0.010$ & $7.2 \pm 3.2$ & $8.3 \pm 2.0$ & $4.2 \pm 0.8$ \\
\hline TA.8 & $0.4+00.6$ & $0.57 \pm 0.10$ & $0.79 \pm 0.20$ & $-0.001 \pm 0.006 i$ & $0.026 \pm 0.012$ & $9.0 \pm 4.0$ & $14 \pm 3.0$ & $4.0 \pm 0.8$ \\
\hline TA.49* & $0.4 \pm 0.6$ & $1.04 \pm 0.20$ & $\ldots$ & $-(0.0011 \pm 0 .(x) !$ & $0.018 \pm 0.008$ & $9.0 \pm 4.0$ & $0.5 \pm 2.2$ & $4.8 \pm 1.0$ \\
\hline Frijoles: & $96 \pm 3.2$ & $1.29 \pm 0.24$ & $\ldots$ & $-0.0022 \pm 0.003$ & $0.024 \pm 0.010$ & $10 \pm 4.0$ & $13 \pm 2.8$ & $4.7 \pm 1.0$ \\
\hline North Mea" & $0.5 \pm 0.6$ & $0.90 \pm 0.16$ & $\ldots$ & $-0.001 \pm 0.0003$ & $0.057 \pm 0.012$ & $9.0 \pm 4.0$ & $9.4 \pm 2.2$ & $4.4 \pm 0.8$ \\
\hline Eest of Aisport" & $0.3 \pm 0.6$ & $0.43 \pm 0.08$ & $1.1 \pm 0.201$ & $0.001 \pm 0.004$ & $0.013 \pm 0.008$ & $8.4 \pm 3.6$ & $7.9 \pm 1.8$ & $4.0 \pm 0.8$ \\
\hline West of Airport' & $0.9 \pm 0.6$ & $1.18 \pm 0.20$ & $0 . w \pm 0.14$ & $0.004 \pm 0.004$ & $0.066 \pm 0.012$ & $7.7 \pm 3.4$ & $9.0 \pm 2.0$ & $6.3 \pm 1.0$ \\
\hline South SR-4 Near S-Sito & $3.0 \pm 0.8$ & $0.96 \pm 0.18$ & $\ldots$ & $0.001 \pm 0.003$ & $0.019 \pm 0.006$ & $7.2 \pm 3.2$ & $8.7 \pm 2.0$ & $5.1 \pm 1.0$ \\
\hline No. of Analyow & 8 & 8 & 3 & 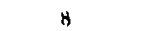 & 8 & 8 & 8 & 8 \\
\hline Minimum & $0.3 \pm 0.6$ & $0.43 \pm 0.06$ & $0.03 \pm 0.14$ & $\because: 004 \pm 0.004$ & $0.013 \pm 0.0008$ & $7.2 \pm 0.2$ & $7: 9 . \pm 1.8$ & $4.0 \pm 0.8$ \\
\hline Meximum & $96 \pm 3.2$ & $1.29 \pm 0.24$ & $1.1 \pm 0.20$ & $0.004 \pm 0.004$ & $0.066 \pm 0.012$ & $10 \pm 4.0$ & $14 . \pm 3.0$ & $6.3 \pm 1.0$ \\
\hline Averaye & $13 \pm 67$ & $0.92 \pm 0.58$ & $0.64 \pm 1.1$ & $0.000 \pm 0.005$ & $0.031 \pm 0.039$ & $8.4 \pm 2.0$ & $9.9 \pm 4.5$ & $1.6 \pm 1.0$ \\
\hline \multicolumn{9}{|l|}{ Sediments } \\
\hline Guajo Near G-1" &.- & $0.00 \neq 0.20$ & $-0.05 \pm 0.16$ & $-0.0002 \pm 0.002$ & $-0.002 \pm 0.003$ & $1.5 \pm 0.8$ & $1.1 \pm 0.6$ & $2.2 \pm 0.4$ \\
\hline Guaje at SR-40 & $\cdots$ & $0.09 \pm 0.06$ & $0.29 \pm 0.18$ & $0.0000 \pm 0.002$ & $0.001 \pm 0.002$ & $2.0 \pm 1.8$ & $2.1 \pm 3.1$ & $3.1 \pm 0.6$ \\
\hline Bayo at SR.4 & ... & $0.06 \pm 0.06$ & $\ldots$ & $-0.001 \pm 0.002$ & $-0.001 \pm 0.002$ & $2.3 \pm 1.2$ & $1.6 \pm 0.8$ & $1.8 \pm 0.4$ \\
\hline Pueblo at Acid Weir & $\cdots$ & $1.03 \pm 0.18$ & $0.68 \pm 0: 20$ & $0.068 \pm 0.012$ & $10.6 \pm 0.60$ & $12 \pm 4.0$ & $6.0 \pm 1.4$ & $2.7 \pm 0.6$ \\
\hline Pueblo at PC-1* & $\cdots$ & $0.12 \pm 0.08$ & $1.48 \pm 0.26$ & $0.003 \pm 0.004$ & $0.023 \pm 0.008$ & $3.3 \pm 1.6$ & $6.6 \pm 1.4$ & $2.6 \pm 0.6$ \\
\hline Pueblo at Pueblo 10 & $\ldots$ & $0.29 \pm 0.08$ & $2.25 \pm 0.30$ & $-0.004 \pm 0.010$ & $0.270 \pm 0.060$ & $8.4 \pm 3.0$ & $12 \pm 2.6$ & $3.8 \pm 0.8$ \\
\hline Pueblo at Pueblo 2 & $\cdots$ & $0.13 \pm 0.06$ & $0.30 \pm 0.16$ & $0.001 \pm 0.006$ & $0.630 \pm 0.060$ & $2.7 \pm 1.4$ & $3.3=1.6$ & $3.8 \pm 0.8$ \\
\hline Low Alamos at Revervoir & $\ldots$ & $0.11 \pm 0.06$ & $0.08 \pm 0.16$ & $-0.001 \pm 0.004$ & $0.002 \pm 0.004$ & $4.1 \pm 2.0$ & $2.7 \pm 1.0$ & $2.6 \pm 0.6$ \\
\hline Loa Alamas at Touvie.. & $\ldots$ & $1.39 \pm 0.42$ & $0.28 \pm 0.14$ & $0.006 \pm 0.005$ & $0.270 \pm 0.026$ & $3.0 \pm 5.3$ & $3.1 \pm 4.9$ & $3.0 \pm 3.1$ \\
\hline Loo Alumoe at LA-2a" & $\ldots$ & $0.62 \pm 0.18$ & $0.10 \pm 0.18$ & $0.0110 \pm 0.024$ & $0.638 \pm 1.42$ & $1.3 \pm 1.4$ & $1.6 \pm 1.7$ & $2.2 \pm 0.7$ \\
\hline Lou Alamoe at Rio Grande.,. & ... & $0.07 \pm 0.14$ & $0.07 \pm 0.11$ & $0.000 \pm 0.001$ & $0.162 \pm 0.444$ & $2.4 \pm 1.9$ & $1.8 \pm 2.8$ & $1.8 \pm 1.6$ \\
\hline Sendia et Rio Grande & - & $0.06 \pm 0.04$ & $-0.11 \pm 0.22$ & $-0 .(x) 1 \pm 0.002$ & $0.000 \pm 0.002$ & $3.1 \pm 0.8$ & $2.5 \pm 0.8$ & \\
\hline Canada del Ancha & $\ldots$ & $0.06 \pm 0.06$ & $0.12 \pm 0.22$ & $\therefore(0.001 \pm 0.002$ & $0.003 \pm 0.004$ & $2.4 \pm 1.2$ & $2.3 \pm 0.6$ & $1.1 \pm 0.8$ \\
\hline Mortantad at SR-4 & $\ldots$ & $0.16 \pm 0.12$ & $\begin{array}{c}0.12 \times 0.22 \\
\ldots\end{array}$ & $-(0.090) \pm 0.008$ & $0.003 \pm 0.006$ & $6.8 \pm 3.0$ & $6.2 \pm 1.4$ & $3.6 \pm 0.8$ \\
\hline Mortantad at Rio Grande & $\cdots$ & $-0.09 \pm 0.10$ & $0.06 \pm 0.18$ & $0 .(K x) \pm 0.000$ & $0.000 \pm 0.000$ & $2.1 \pm 1.0$ & $1.6 \pm 0.6$ & $4.8 \pm 0.8$ \\
\hline Canada de Buey at SR-4 & $\ldots$ & $0.16 \pm 0.10$ & $\begin{array}{c}0.00 \times 0.10 \\
\ldots\end{array}$ & $0 .(x) 1 \pm 0.004$ & $0.003 \pm 0.004$ & $3.1 \pm 1.6$ & $4.5 \pm 1.2$ & $2.5 \pm 0.6$ \\
\hline Pajarito at Rio Grande & $\ldots$ & $0.08 \pm 0.06$ & $-0.70 \pm 1.00$ & $0.0111 \pm 0.004$ & $0.003 \pm 0.0 \times 4$ & $1.7 \pm 1.6$ & $2.3 \pm 0.6$ & $1.7 \pm 0.8$ \\
\hline Frijoles at Park Hdq. & $\ldots$ & $0.03 \pm 0.16$ & ... & $-0.00) 1 \pm 0.004$ & $0.004 \pm 0.003$ & $2.0 \pm 2.0$ & $2.8 \pm 1.0$ & $3.0 \pm 0.6$ \\
\hline Frijoles at Rio Grando & $\ldots$ & $0.12 \pm 0.10$ & $2.0 \pm 0.40$ & $-0.001 \pm .0 .002$ & $-0.002 \pm 0.004$ & $1.2 \pm 1.2$ & $1.0 \pm 0.4$ & $4.6 \pm 0.8$ \\
\hline No. of Analyese & ... & 31 & 17 & 23 & 23 & 23 & 23 & 23 \\
\hline Minimum & $\cdots$ & $-0.09 \pm 0.10$ & $-0.70 \pm 1.00$ & $-0.0 \times 44 \pm 0.010$ & $-0.002 \pm 0.004$ & $0.8 \pm 0.4$ & $0.9 \pm 0.4$ & $1.1 \pm 0.8$ \\
\hline Maximum & $\ldots$ & $1.53 \pm 0.26$ & $2.26 \pm 0.30$ & $0.14+200.01012$ & $10.6 \pm 0.60$ & $12 \pm 4.0$ & $12 \pm 2.6$ & $4.8 \pm 0.8$ \\
\hline Average & $\ldots$ & $0.45 \pm 0.96$ & $0.46 \pm 1.46$ & $0.004 \pm 0.029$ & $0.596 \pm 4.40$ & $3.1 \pm 6.0$ & $3.1 \pm 1.9$ & $2.7 \pm 2.0$ \\
\hline
\end{tabular}

Hadioactivity above natural or world-wide fallout concentrations

Two analyaes.

Note: \pm value represents twice the standard deviation of the distrihution ul chserved suluem an.

less only une analyois is reported, then the value represento $t$ wict the unceduinty termi fir

that analyais. 
TABLE E-XVIJI

RADIOCHEMICAL ANALYSES OF ONSITE SOILS AND SEDIMENTS

\begin{tabular}{|c|c|c|c|c|c|c|c|c|}
\hline Station: & $\begin{array}{c}{ }^{3 \mathrm{H}} \\
\left(10^{-\bullet} \cdot{ }^{\mu} \mathrm{C} \mathrm{i} / \mathbf{m} \ell\right)\end{array}$ & $\begin{array}{r}{ }^{137} \mathrm{C} \\
(\mathrm{pCi} / \mathrm{q})\end{array}$ & $\begin{array}{c}m \mathrm{~s} / \mathbf{r} \\
(\mathrm{pCi} / \mathrm{c})\end{array}$ & $\begin{array}{c}{ }^{24} \mathrm{Pu} \\
(\mathrm{pCi} / \mathrm{g})\end{array}$ & $\begin{array}{c}{ }^{20} \mathrm{Pu} u \\
(\mathrm{pCi} / \mathrm{g})\end{array}$ & $\begin{array}{l}\text { Grose } \alpha \\
(\mathrm{pCi} / \mathrm{s})\end{array}$ & $\begin{array}{l}\text { Groses } p \\
(\mathrm{pCi} / \mathrm{c})\end{array}$ & $\begin{array}{c}\text { Total U } \\
(\mu \alpha / c)\end{array}$ \\
\hline \multicolumn{9}{|l|}{ Soils } \\
\hline TA.21 & $1.9 \pm 0.6$ & $0.03 \pm 0.12$ & $0.13 \pm 0.16$ & $0.001 \pm 0.003$ & $0.017 \pm 0.06 \%$ & $7.3 \pm 3.2$ & $6.1 \pm 1.6$ & $3.5 \pm 0.8$ \\
\hline TA-50" & $1.9 \pm 0.6$ & $0.16 \pm 0.08$ & $0.25 \pm 0.20$ & $-0.0002 \pm 0.004$ & $0.0233 \pm 0.0 \times 18$ & 12. \pm 3.0 & $7.5 \pm 1.8$ & $4.4 \pm 0.8$ \\
\hline TA.36 & $1.2 \pm 0.6$ & $0.18 \pm 0.08$ & $\ldots$ & $0.001 \pm 0.104$ & $0.002 \pm 0.004$ & $8.9 \pm 3.8$ & $7.6 \pm 1.8$ & $4.2 \pm 0.8$ \\
\hline PM-1* & $1.3 \pm 0.6$ & $0.94 \pm 0.16$ & $\ldots$ & $0.002 \pm 0.006$ & $0.022 \pm 0.004$ & 11. \pm 4.0 & $15 \pm 3.2$ & $6.5 \pm 1.4$ \\
\hline West of TA-53" & $1.3 \pm 0.6$ & $1.15 \pm 0.24$ & $0.56 \pm 0.18$ & $0.00 \times 0 \pm 0.002$ & $0.076 \pm 0.010$ & 16. \pm 4.0 & 19. \pm 4.0 & $7.1 \pm 1.4$ \\
\hline East of TA-53* & $2.0 \pm 0.6$ & $1.22 \pm 0.20$ & $0.35 \pm 0.16$ & $0.001 \pm 0.004$ & $0.031 \pm 0.010$ & 10. \pm 4.0 & $12 \pm 2.6$ & $4.2 \pm 0.8$ \\
\hline East of New Sigma I* & 17. \pm 1.0 & $0.63 \pm 0.12$ & -- & $0.078 \pm 0.012$ & $0.054 \pm 0.010$ & 10. \pm 4.0 & $11 \pm 2.6$ & $3.4 \pm 0.6$ \\
\hline East of New Sigma II* & $3.6 \pm 0.8$ & $0.94 \pm 0.20$ & -.- & $0.002 \pm 0.002$ & $0.061 \pm 0.012$ & 10. \pm 4.0 & $15 \pm 3.2$ & $6.1 \pm 1.2$ \\
\hline East of TA-52 & $2.5 \pm 0.6$ & $0.15 \pm 0.08$ & $\ldots$ & $0.234 \pm 0.022$ & $0.127 \pm 0.016$ & 13. \pm 6.0 & $9.7 \pm 2.2$ & $3.7 \pm 0.8$ \\
\hline 2-Mile Mesa & $0.9 \pm 0.6$ & $0.60 \pm 0.12$ & -.- & $0.002 \pm 0.002$ & $0.009 \pm 0.004$ & $6.4 \pm 2.8$ & $6.5 \pm 1.6$ & $3.9 \pm 0.8$ \\
\hline Near TA-51 & $1.1 \pm 0.6$ & $0.11 \pm 0.10$ & $0.90 \pm 0.20$ & $0.000 \pm 0.004$ & $0.013 \pm 0.006$ & $6.4 \pm 2.8$ & $5.9 \pm 1.4$ & $3.8 \pm 0.8$ \\
\hline East of TA.54" & $13, \pm 1.0$ & $0.18 \pm 0.08$ & $0.23 \pm 0.26$ & $-0.001 \pm 0.004$ & $0.001 \pm 0.004$ & 18. \pm 8.0 & $17 \pm 3.6$ & $4.8 \pm 1.0$ \\
\hline R-Site Roede & $0.4 \pm 0.6$ & $3.1 \pm 0.40$ & $\ldots$ & $0.003 \pm 0.003$ & $0.061 \pm 0.012$ & $8.6 \pm 3.8$ & $13 \pm 2.8$ & $4.0 \pm 0.8$ \\
\hline R-Site Road East" & $5.8 \pm 0.8$ & $1.04 \pm 0.18$ & $0.41 \pm 0.18$ & $-0.002 \pm 0.006$ & $0.031 \pm 0.012$ & 14. \pm 6.0 & $17 \pm 3.8$ & $7.8 \pm 1.6$ \\
\hline Potrillo Drive & $1.4 \pm 0.6$ & $0.77 \pm 0.14$ & -.. & $-0.005 \pm 0.010$ & $0.015 \pm 0.012$ & $10 . \pm 4.0$ & $9.0 \pm 2.0$ & $4.1 \pm 0.8$ \\
\hline S-Site & $0.2 \pm 0.6$ & $0.74 \pm 0.14$ & $\ldots$ & $0.001 \pm 0.002$ & $0.012 \pm 0.004$ & 12. \pm 6.0 & $14 \pm 3.2$ & $4.1 \pm 0.8$ \\
\hline Near TA-11 & $1.7 \pm 0.6$ & $0.59 \pm 0.12$ & $\cdots$ & $0.001 \pm 0.004$ & $0.010 \pm 0.006$ & $6.2 \pm 2.8$ & $7.0 \pm 1.6$ & $4.1 \pm 0.8$ \\
\hline Near DT-9 & $2.5 \pm 0.6$ & $0.72 \pm 0.14$ & $\cdots$ & $-0.002 \pm 0.004$ & $0.013 \pm 0.008$ & $9.0 \pm 4.0$ & $9.3 \pm 2.2$ & $4.3 \pm 0.8$ \\
\hline Near TA-33 & $26 \pm 1.2$ & $0.94 \pm 0.16$ & $\cdots$ & $-0.001 \pm 0.004$ & $0.017 \pm 0.006$ & $7.8 \pm 3.4$ & $8.9 \pm 2.0$ & $3.6 \pm 0.8$ \\
\hline No. of Analyses & 19 & 19 & 7 & 19 & 19 & 19 & 19 & \\
\hline Minimum & $0.2 \pm 0.6$ & $0.03 \pm 0.12$ & $0.13 \pm 0.16$ & $-0.002 \pm 0.004$ & $0.012 \pm 0.004$ & $6.2 \pm 2.8$ & $6.1 \pm 1.6$ & $3.4 \pm 0.6$ \\
\hline Maximum & $26 \pm 1.2$ & $3.1 \pm 0.40$ & $0.90 \pm 0.20$ & $0.234 \pm 0.022$ & $0.127 \pm 0.016$ & 18. \pm 8.0 & $18 \pm 4.0$ & $7.8 \pm 1.6$ \\
\hline Average & $4.5 \pm 14$ & $0.75 \pm 1.37$ & $0.40 \pm 0.52$ & $0.016 \pm 0.111$ & $0.081 \pm 0.063$ & $10 \pm 6.5$ & $11 \pm 8.2$ & $4.6 \pm 2.6$ \\
\hline \multicolumn{9}{|l|}{ Sediment: } \\
\hline Pueblo at Hamilton Bend Spr" & $\cdots$ & $0.05 \pm 0.06$ & $1.10 \pm 0.26$ & $0.002 \pm 0.006$ & $0.470 \pm 0.040$ & $4.2 \pm 2.0$ & $2.6 \pm 0.8$ & $4.3 \pm 0.8$ \\
\hline Pueblo at Pueblo $3^{2}$ & $\cdots$ & $0.02 \pm 0.08$ & $0.03 \pm 0.16$ & $0.001 \pm 0.002$ & $0.215 \pm 0.022$ & $1.5 \pm 0.3$ & $1.8 \pm 0.4$ & $1.8 \pm 0.4$ \\
\hline Pueblo at SR-4, & $\ldots$ & $0.14 \pm 0.28$ & $0.04 \pm 0.11$ & $0.001 \pm 0.001$ & $0.493 \pm 0.095$ & $1.4 \pm 1.2$ & $1.1 \pm 1.3$ & $2.1 \pm 0.4$ \\
\hline DP Canyon at DPS-1" & $\cdots$ & $8.7 \pm 1.2$ & $\ldots$ & $0.536 \pm 0.028$ & $1.070 \pm 0.040$ & ... & $\ldots$ & -- \\
\hline DP Cenyon at DPS.4a.b & $\cdots$ & $17 \pm 8.8$ & $3.47 \pm 0.17$ & $0.195 \pm 0.178$ & $0.683 \pm 0.177$ & -.. & $\cdots$ & ..- \\
\hline Los Alamos at Bridge & $\cdots$ & $0.14 \pm 0.12$ & $0.10 \pm 0.16$ & $0.000 \pm 0.002$ & $0.001 \pm 0.003$ & $2.0 \pm 1.0$ & $1.7 \pm 0.8$ & $2.1 \pm 0.4$ \\
\hline Los Alamos at LAO-1" & $\cdots$ & $0.79 \pm 0.18$ & $0.18 \pm 0.20$ & $-0.002 \pm 0.006$ & $0.361 \pm 0.040$ & $4.0 \pm 1.8$ & $2.9 \pm 1.0$ & $3.1 \pm 0.6$ \\
\hline Los Alamos at GS-1".to & $\cdots$ & $0.09 \pm 0.10$ & $0.52 \pm 0.74$ & $0.000 \pm 0.001$ & $0.217 \pm 0.331$ & $1.4 \pm 0.1$ & $0.8 \pm 0.3$ & $1.7 \pm 0.4$ \\
\hline Los Alamos at TW-3, & $\cdots$ & $19 \pm 7.3$ & $3.40 \pm 1.61$ & $0.214 \pm 0.219$ & $0.775 \pm 0.552$ & $6.9 \pm 12$ & $22 \pm 23$ & $5.8 \pm 1.2$ \\
\hline Lo Alamos at LAO-4 & $\cdots$ & $12 \pm 0.0$ & $1.05 \pm 1.32$ & $0.137 \pm 0.062$ & $0.616 \pm 0.209$ & $4.8 \pm 4.2$ & $16 \pm 9.2$ & $3.2 \pm 0.6$ \\
\hline Los Alamos at SR-4, & ... & $7.25 \pm 6.36$ & $0.49 \pm 0.41$ & $0.061 \pm 0.001$ & $0.363 \pm 0.076$ & $2.8 \pm 4.1$ & $11 \pm 21$ & $3.7 \pm 0.8$ \\
\hline Sandia at SCS-2 & $\cdots$ & $0.05 \pm 0.12$ & $0.19 \pm 0.28$ & $0.000 \pm 0.003$ & $0.002 \pm 0.003$ & $2.2 \pm 1.2$ & $1.4 \pm 0.8$ & $2.2 \pm 0.4$ \\
\hline Sandia at SR-4" & ..- & $0.20 \pm 0.08$ & $1.08 \pm 0.20$ & $-0.001 \pm 0.006$ & $-0.002 \pm 0.004$ & $2.5 \pm 1.2$ & $1.7 \pm 0.8$ & $3.0 \pm 0.6$ \\
\hline Martandad near CMR* & $\cdots$ & $0.28 \neq 0.08$ & $0.24 \pm 0.17$ & $0.183 \pm 0.028$ & $0.041 \pm 0.012$ & $3.8 \pm 1.8$ & $4.2 \pm 1.2$ & $2.2 \pm 0.4$ \\
\hline
\end{tabular}


TABLE E-XVIII (Cont)

RADIOCHEMICAL ANALYSES OF ONSITE SOILS AND SEDIMENTS

\begin{tabular}{|c|c|c|c|c|}
\hline Seations & $\left(10^{-\bullet} \cdot \mu \mathrm{Ci} / \mathrm{ml}\right)$ & $\begin{array}{c}{ }^{17} \mathrm{Cs} \\
(\mathrm{pCi} / \mathrm{s})\end{array}$ & $\begin{array}{c}\mathrm{Sr} \\
(\mathrm{pCV} / \mathrm{g}) \\
\end{array}$ & $\begin{array}{c}{ }^{m} \mathrm{Pu} \\
(\mathrm{pCi} / \mathrm{c})\end{array}$ \\
\hline Murtandad near MCO-2 & $\cdots$ & $0.23 \pm 0.06$ & $\cdots$ & $0.004 \pm 0.004$ \\
\hline Mortandad at GS.1" & $\cdots$ & $360 \pm 60$ & $\cdots$ & $5.75 \pm 0.120$ \\
\hline Mortanded at MCO-5" & $\ldots$ & $56 \pm 8$ & $\cdots$ & $3.390 \pm 0.080$ \\
\hline Mortandad at MCO-7" & $\cdots$ & $38 \pm 6$ & $\cdots$ & $1.220 \pm 0.040$ \\
\hline Mortandad at MCO-9" & $\cdots$ & $0.66 \pm 0.12$ & $1.73 \pm 0.36$ & $0.000 \pm 0.002$ \\
\hline Mortandad at MCO-13 & $\cdots$ & $0.89 \pm 0.14$ & $0.38 \pm 0.20$ & $-0.001 \pm 0.003$ \\
\hline Pajarito at TA-18 & $\cdots$ & $0.58 \pm 0.14$ & $\cdots$ & $0.003 \pm 0.006$ \\
\hline Pajarito at SR-4 & $\cdots$ & $0.29 \pm 0.10$ & $\cdots$ & $-0.001 \pm 0.003$ \\
\hline Potrillo at TA-36" & $\cdots$ & $0.23 \pm 0.14$ & ... & $-0.001 \pm 0.003$ \\
\hline Potrillo East of TA-36" & $\cdots$ & $0.12 \pm 0.14$ & $1.90 \pm 0.40$ & $-0.001 \pm 0.002$ \\
\hline Potrillo at SR-4 & $\cdots$ & $0.22 \pm 0.12$ &.- & $-0.002 \pm 0.004$ \\
\hline Water at Beta Hole & $\cdots$ & $0.10 \pm 0.08$ & -.. & $-0.001 \pm 0.004$ \\
\hline Water at SR.4 & $\cdots$ & $0.56 \pm 0.12$ & --- & $-0.005 \pm 0.004$ \\
\hline Water at Rio Grande & $\cdots$ & $0.15 \pm 0.12$ & $\cdots$ & $-0.001 \pm 0.002$ \\
\hline Anchio at SR-4 & $\cdots$ & $0.10 \pm 0.16$ & $\ldots$ & $0.019 \pm 0.018$ \\
\hline Ancho at Rio Grande & -- & $0.13 \pm 0.08$ & -- & $-0.001 \pm 0.002$ \\
\hline Chaquihui at Rio Grande & $\cdots$ & $0.18 \pm 0.10$ & $\cdots$ & $-0.001 \pm 0.002$ \\
\hline No. of Analyses & & 37 & 16 & 37 \\
\hline Minimum & & $0.02 \pm 0.08$ & $0.00 \pm 0.20$ & $-0.005 \pm 0.004$ \\
\hline Maximum & & $360 \pm 60$ & $3.97 \pm 0.38$ & $5.75 \pm 0.120$ \\
\hline Average & & $16 \pm 119$ & $0.98 \pm 2.30$ & $0.333 \pm 217$ \\
\hline
\end{tabular}

\begin{tabular}{|c|c|}
\hline $\begin{array}{c}{ }^{200} \mathrm{Pu} \\
(\mathrm{pCV} / \mathrm{s})\end{array}$ & $\begin{array}{l}\text { Grose a } \\
\text { (pCive) }\end{array}$ \\
\hline $0.010 \pm 0.004$ & ... \\
\hline $2.380 \pm 0.60$ & ... \\
\hline $0.715 \pm 0.032$ & -- \\
\hline $0.350 \pm 0.011$ & $\ldots$ \\
\hline $0.012 \pm 0.0044$ & $3.8 \pm 1.8$ \\
\hline $0.035 \pm 0.0088$ & $8.3 \pm 3.6$ \\
\hline $0.012 \pm 0.008$ & $7.4 \pm 3.4$ \\
\hline $0.010 \pm 0.0066$ & $6.6 \pm 3.0$ \\
\hline $0.001 \pm 0.003$ & 14. \pm 6.0 \\
\hline $0.000 \pm 0.002$ & $3.4 \pm 1.6$ \\
\hline $0.009 \pm 0.010$ & $1.9 \pm 1.0$ \\
\hline $0.002 \pm 0.004$ & $1.8 \pm 1.0$ \\
\hline $0.008 \pm 0.00 \mathrm{j}$ & $6.5 \pm 14$ \\
\hline$-0.001 \pm 0.002$ & $1.9 \pm 0.8$ \\
\hline $0.002 \pm 0.012$ & $1.2 \pm 0.8$ \\
\hline $0.002 \pm 0.004$ & $2.5 \pm 1.2$ \\
\hline $0.004 \pm 0.004$ & $1.9 \pm 1.0$ \\
\hline 37 & 31 \\
\hline$-0.002 \pm 0.004$ & $0.9 \pm 0.4$ \\
\hline $2.38 \pm 0.060$ & $14 \pm 6.0$ \\
\hline $0.324 \pm 0.932$ & $3.8 \pm 6.1$ \\
\hline
\end{tabular}

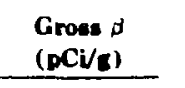

Total U

$(\mu / \sqrt{c})$

(1)

$\ldots$

-.

$-\cdot$

$4.9 \pm 1.2$

$10.7 \pm 2.4 \quad 3.2 \pm 0.3$

$9.5 \pm 2.2 \quad 5.7 \pm 1.2$

$6.6 \pm 1.6 \quad 3.1 \pm 0.6$

$32 \pm 6.0 \quad 15 \pm 3.0$

$3.6 \pm 1.0 \quad 4.5 \pm 1.0$

$1.4 \pm 0.8 \quad 2.5 \pm 0.6$

$2.0 \pm 0.8 \quad 1.7 \pm 0.4$

$9.0 \pm 2.0 \quad 3.6 \pm 0.8$

$1.5 \pm 0.6 \quad 1.9 \pm 0.8$

$1.8 \pm 0.8 \quad 1.7 \pm 0.4$

$2.9 \pm 0.4 \quad 1.8 \pm 0.8$

$1.7 \pm 0.6 \quad 2.3 \pm 0.8$

31

25

$0.6 \pm 0.4 \quad 1.7 \pm 0.4$

$32 \pm 6.0 \quad 16 \pm 3.0$

$7 \pm 16 \quad 3.4 \pm 5.3$

- One or more radiunuclides above natural or worldwide fallout concentrations.

'Two or more analyses for selected radionuclides.

Note: \pm value represents twice the standard deviation of the distribution of observed values unless only one analysis is reported, then the value represents twice the uncertainty term for that analysis. 
TABLE L-XIX

MAINOCHEMICAL, AND CHEMICAL ANALYSES OF SNOWMEI.'I KUNOFF"

(averace of a number of analyees)

\begin{tabular}{|c|c|c|c|c|c|c|}
\hline Solution & $\stackrel{\cdot H}{(10 \cdot \mu \mathrm{CL} / \mathrm{m} l)}$ & 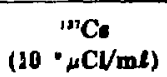 & $\begin{array}{c}{ }^{m} \mathrm{Pu} \\
\left(10^{-1} \mu \mathrm{CV} / \mathrm{ml}\right)\end{array}$ & $\begin{array}{c}{ }^{\operatorname{sm}} \mathrm{Pu} \\
\left(10^{-} \mu \mathrm{Ci} / \mathrm{ml}\right)\end{array}$ & $\begin{array}{c}{ }^{m} \mathrm{Sr} \\
\left(10^{-*}{ }_{\mu} \mathrm{Ci} / \mathrm{m} l\right)\end{array}$ & $\begin{array}{c}\text { Total U } \\
(\mu / / l)\end{array}$ \\
\hline Ciuaje Canyon & $0.0 \pm 0.8(10)^{\circ}$ & $-5 \pm 73(10)$ & $-0.02 \pm 0.06(10)$ & $-0.05 \pm 11.26(10)$ & $0.6 \pm(0.6(10)$ & $0.0 \pm 0.3(10)$ \\
\hline Kendija C'anyın & $0.4 \pm 0.2(4)$ & $12 \pm 25(4)$ & $-0.02 \pm 0 .(15(4)$ & $-0 .(0) 1 \pm 0.166(4)$ & $\cdots$ & $0.2 \pm 0.4(4)$ \\
\hline rueblu at SR-4 & $0 / 4 \pm 0.7(5)$ & $-7 \pm 41(5)$ & $-0.01 \pm 0.04(5)$ & $0.13 \pm 0.52(5)$ & $\ldots$ & $0.4 \pm 0.5(5)$ \\
\hline Iss Alamosi at Silk-4 & $1.3 \pm 14(14)$ & $6 \pm 44(14)$ & $-0.0: 3 \pm 0.14(13)$ & $-0.011 \pm 0.281131$ & $3.11 \pm 5.3(10)$ & $0.6 \pm 1.9(14)$ \\
\hline IAs Alumes at T'ulovi & $1.2 \pm 1.1(11)$ & $11 \pm 92(10)$ & $-0.02 \pm 0.06(10)$ & $0 .(n) \pm(0.05(10)$ & $3.4 \pm 3.6(10)$ & $0.3 \pm 0.7(11)$ \\
\hline Ias Alamos at (Howi & $0.9 \pm 1.1(8)$ & $8 \pm 40(8)$ & $-0.02 \pm 0.05(8)$ & $0 .(x) \pm 0.11(8)$ & $3.0 \pm 2.3(8)$ & $0.8 \pm 1.4(8)$ \\
\hline Mirtandisd at $\mathrm{MC} C^{\circ} \mathrm{O}-5$ & $67 \pm 32(4)$ & $13 \pm 32(4)$ & $1.34 \pm 0.511(4)$ & $0.52 \pm 0.17(4)$ & $40.5 \pm 2.5(2)$ & $2.2 \pm 1.1(4)$ \\
\hline P'ujurito at Sik-4 & $1.7 \pm 10 . B(14)$ & $B \pm 52(14)$ & $-0.03 \pm 0.16(14)$ & $0.00 \pm 0.07\{14\}$ & $0.5 \pm 0.9(10)$ & $0.3 \pm 0.6(14)$ \\
\hline Water at SiR-4 & $0.4 \pm(1.6(\mathrm{H})$ & $20 \pm 61(8)$ & $-0.02 \pm 0.09(8)$ & $-0.01 \pm 0: 2(8)$ & $0.7 \pm 0.6(5)$ & $0.4 \pm 0.8(8)$ \\
\hline Ancho at SiH-4 & $1.5 \pm 1.1(8)$ & $-9 \pm 17(7)$ & $0.00 \pm 0.04(7)$ & $0.01 \pm 0.115(7)$ & $0.8 \pm 0.8(7)$ & $0.2 \pm 0.4(7)$ \\
\hline
\end{tabular}

\section{Suspended Sedimente}

livaje C'rnyon

Rendija Canyon

Pueblo at SR.4

ind Alamos at SiR.4

Ior Alamos at 'Thovi

los Alamus at (Howi

Mortandad at MCO.5

P'ejarito at SH-4

Water at SR-4

Ancho at SR-4

$\begin{array}{ll} & \\ \ldots & \\ \cdots & \cdots \\ \cdots & \cdots \\ \cdots & \cdots \\ \cdots & \cdots \\ \cdots & \cdots \\ \cdots & \cdots \\ \cdots & \cdots \\ \cdots & \cdots \\ & \cdots\end{array}$

\section{(pCWc)}

\begin{tabular}{|c|c|}
\hline (pCVa) & $(\mathrm{pCi} / \mathrm{s})$ \\
\hline$-0.17 \pm 0.04(10)$ & $0.06 \pm 0.46(10)$ \\
\hline $0.41 \pm 1.8(4)$ & $0.17 \pm 0.59(4)$ \\
\hline $0.04 \pm 0.05(6)$ & $7.5 \pm 2(5)$ \\
\hline $0.56 \pm 1.8(14)$ & $40 \pm 6.4(14)$ \\
\hline $0.52 \pm 0.89(11)$ & $7.4 \pm 9.8(11)$ \\
\hline $0.16 \pm 0.17(6)$ & $3.8 \pm 4.2(6)$ \\
\hline $54 \pm 39(3)$ & $23 \pm 21131$ \\
\hline $0.03 \pm 1.2(13)$ & $0.80 \pm 5.4\left(1^{2}\right)$ \\
\hline $0.00 \pm 0.05(8)$ & $11.166 \pm 0.26(8)$ \\
\hline $0.001 \pm 0.03(6)$ & $0.10 \pm 0.17(6)$ \\
\hline
\end{tabular}

Chemical

(averace of a number of analyeas, in $m / 4$ )

\begin{tabular}{|c|c|c|c|c|c|c|}
\hline & & (avers: & of a num & or of analy & $a n$, in $m(/ 4)$ & \\
\hline & $\begin{array}{c}\text { No. of } \\
\text { Analynes }\end{array}$ & so. & CL & $\boldsymbol{F}$ & No, & TDS \\
\hline Guaje Canyon & 10 & $14 \pm 0$ & $3 \pm 2$ & $0.3 \pm 0.7$ & $<1 \pm 2$ & $145 \pm 58$ \\
\hline Kendija Canyon & 4 & ... & $6 \pm 3$ & $0.2 \pm 0.1$ & $3 \pm 2$ & $162 \pm 58$ \\
\hline Pueblo at SR-4 & 5 & $\ldots$ & $32 \pm 5$ & $0.6 \pm 0.2$ & $20 \pm 7$ & $285 \pm 78$ \\
\hline Log Alamos at SK-4 & 14 & $12 \pm 2$ & $20 \pm 20$ & $0.6 \pm 0.6$ & $3 \pm 6$ & $149 \pm 91$ \\
\hline Los Alamus at Totavi & 11 & $13 \pm 2$ & $15 \pm 14$ & $0.5 \pm 0.6$ & $3 \pm 8$ & $156 \pm 52$ \\
\hline Los Alamos at (Stuwi & 8 & $\ldots$ & $16 \pm 7$ & $0.4 \pm 0.2$ & $2 \pm 2$ & $193 \pm 72$ \\
\hline Mortandad at MCO-5 & 4 & $\ldots$ & $18 \pm 5$ & $1.4 \pm 1.6$ & $116 \pm 103$ & $500 \pm 169$ \\
\hline Pajarito at SK-4 & 14 & $14 \pm 0$ & $19 \pm 7$ & $0.2 \pm 0.0$ & $2 \pm 3$ & $179 \pm 70$ \\
\hline Water at SR-4 & 8 & $\ldots$ & $11 \pm 6$ & $0.2 \pm 0.1$ & $2 \pm 2$ & $151 \pm 38$ \\
\hline Ancho at SR-4 & 7 & ... & $b \pm 4$ & $0.2 \pm 0.1$ & $2 \pm 2$ & $148 \pm 42$ \\
\hline
\end{tabular}

Plarembers indicule number of samples unalyzed.

Note: \pm value is twice the standard deviation of the distrilution ol it numbel of anialsis. 
TABLE E-XX

\section{ATMOSPHERIC RADIOACTIVE EFFLUENT TOTAIS FOR 1:79,}

\begin{tabular}{|c|c|c|c|c|c|c|c|c|c|c|c|}
\hline Location & $\begin{array}{l}{ }^{m P u} \\
\operatorname{mPu}^{2} \\
(\mu \mathrm{Ci})\end{array}$ & $\begin{array}{l}{ }^{211} \mathrm{Am} \\
(\mu \mathrm{Ci})\end{array}$ & $\begin{array}{c}\operatorname{se} U \\
(\mu \mathrm{Ci})\end{array}$ & $\begin{array}{l}{ }^{*} \mathrm{Th} \\
{ }^{*} \mathrm{Th} \\
\text { (fCi) }\end{array}$ & $\begin{array}{l}\text { MFP } \\
(\mu \mathrm{Ci})\end{array}$ & $\begin{array}{r}131 \\
(\mu \mathrm{Ci})\end{array}$ & $\begin{array}{l}{ }^{11} \mathbf{A r} \\
\text { (Ci) }\end{array}$ & $\begin{array}{c}{ }^{32} \mathrm{P} \\
(\underline{\mu \mathrm{Ci}})\end{array}$ & $\begin{array}{c}{ }^{3} \mathbf{H} \\
\text { (Ci) }\end{array}$ & $\begin{array}{c}{ }^{11} \mathrm{C},{ }^{19} \mathrm{~N},{ }^{18} \mathrm{O}^{\mathrm{b}} \\
(\mathrm{Ci}) \\
\end{array}$ & $\begin{array}{r}{ }^{7} \mathrm{Be} \\
(\underline{\mu C i})\end{array}$ \\
\hline TA.2 & $\ldots$ & $\cdots$ & $\ldots$ & ... & $\ldots$ & $\ldots$ & 351 & -.. & $\ldots$ & -.. & $\cdots$ \\
\hline TA-3 & 1067 &.- & 261 & 1605 & 472 & 158 & $\ldots$ & $\cdots$ & $3013^{c}$ & -.. & $\ldots$ \\
\hline TA-9 & -.- & -.. & --. & -.. & $\ldots$ & ... & $\cdots$ & -.. & 5.0 & -.. & ... \\
\hline TA-15 & -.- & -.. & $\cdots$ & ... & -.. & ... & $\cdots$ & -.. & $\ldots$ &.- & $\cdots$ \\
\hline TA-18 & ... & -.. & 4.0 & ... & ... & ... & $\cdots$ & -.. & $\ldots$ & -.. & -.. \\
\hline TA-21 & 5.7 & 0.019 & 655 & $\ldots$ & 0.47 & $\cdots$ & $\cdots$ & $\ldots$ & 95 & ... & $\cdots$ \\
\hline TA-33 & $\ldots$ & -- & $\ldots$ &..- & $\ldots$ & -.. & $\ldots$ & $\cdots$ & 10470 &.-- & $\cdots$ \\
\hline TA-35 & 7.4 & --- & $\cdots$ & $-\cdots$ & $\ldots$ & $\ldots$ & $\cdots$ & -.. & 1300 & $\cdots$ & $\cdots$ \\
\hline TA-41 & $\ldots$ & $\ldots$ & $\ldots$ & -.- & $\ldots$ & ... & ... & $\ldots$ & 143 & -.. & ... \\
\hline TA-43 & 0.75 & $\cdots$ & ... &.-- & $\ldots$ & --. & $\cdots$ & 18 & ... & -.. &.-- \\
\hline TA-46 & -.. &.- & 2.3 & $\cdots$ & -.. & --. & ... & ... & -.- & -- & -.. \\
\hline TA-48 & 0.33 &.-- & 6.8 & --- & 1072 & -.. & $\cdots$ & ... & --- & $\cdots$ & $\cdots$ \\
\hline TA-50 & 2.9 & -.- & $\cdots$ &.-- & 11 & $\ldots$ & $\ldots$ & -.- & ... & $\ldots$ &.-- \\
\hline TA-53 & -.. & $\ldots$ & $\ldots$ & $\cdots$ & $\ldots$ & -.. & 357 & -.. & ... & 118800 & 2.6 \\
\hline TA-54 & 0.013 & $\cdots$ & $\cdots$ & $\ldots$ & $\cdots$ & $\cdots$ & $\ldots$ & -- & ... & $\ldots$ & -.- \\
\hline TA-55 & 0.11 &.- & $\cdots$ &.-- & -.. & $\cdots$ & -- & -.- & --. & $\cdots$ & $\ldots$ \\
\hline
\end{tabular}

Mixed fission products.

${ }^{5}$ The half-lives of ${ }^{11} \mathrm{C},{ }^{12} \mathrm{~N}$, and ${ }^{10} \mathrm{O}$ range from about 2 to 20 minutes, so these nuclides decay rapidly.

'Includes $3000 \mathrm{Ci}$ unplanned release from TA-3-34 on May 4, 1979 (see Section III.A.7). 
TABLE E-XXI

TOTAL SUSPENDED PARTICULATES AT LOS ALAMOS AND WHITE ROCK DURING 1979

(Data from New Mexico Environmental Improvement Division. All concentrations in $\mu \mathrm{g} / \mathrm{m}^{2}$.)

Los Alamos (Annual Geometric Mean = 35)

\begin{tabular}{|c|c|c|c|c|c|c|c|c|c|c|c|c|}
\hline & Jan & Feb & Mar & Apr & May & June & July & Aug & Sept & Oct & Nov & Dec \\
\hline No. of Samples & 3 & 2 & ... & 5 & 5 & $\mathbf{5}$ & 5 & 6 & 5 & 5 & 5 & 5 \\
\hline Maximum & 63 & 29 & ... & 77 & 71 & 72 & $5 !$ & 45 & 46 & 40 & 45 & 62 \\
\hline Minimum & 35 & 28 & ..- & 24 & 20 & 21 & 24 & 16 & 22 & 25 & 21 & 27 \\
\hline Mean & 44 & 28 & $\cdots$ & 47 & 34 & 44 & 36 & 37 & 34 & 31 & 29 & 47 \\
\hline \pm 1 Std Deviation & 16 & 1 & $\cdots$ & 22 & 21 & 21 & 11 & 12 & 11 & 6 & 9 & 13 \\
\hline \multicolumn{13}{|c|}{ White Rock (Annual Geometric Mean = 35) } \\
\hline No, of Samples & 4 & 5 & 5 & 5 & 5 & 5 & 5 & 6 & 5 & 5 & 5 & 5 \\
\hline Maximum & 33 & 27 & 51 & 113 & 42 & 89 & 66 & 70 & 59 & 80 & 51 & 62 \\
\hline Minimum & 19 & 15 & 21 & 24 & 13 & 13 & 29 & 28 & 31 & 17 & 14 & 27 \\
\hline Mean & 27 & 23 & 30 & 55 & 22 & $\mathbf{5 1}$ & 47 & 47 & 45 & 49 & 33 & 40 \\
\hline \pm 1 Std Deviation & 6 & $\mathbf{5}$ & 12 & 36 & 12 & 33 & 13 & 17 & 11 & 29 & 15 & 14 \\
\hline
\end{tabular}


TABLE E-XXII

QUANTITIES OF VOLATILE CHEMICALS AND COMPRESSED GASES USED AT LASL (All amounts in $\mathbf{~ g g}$ )

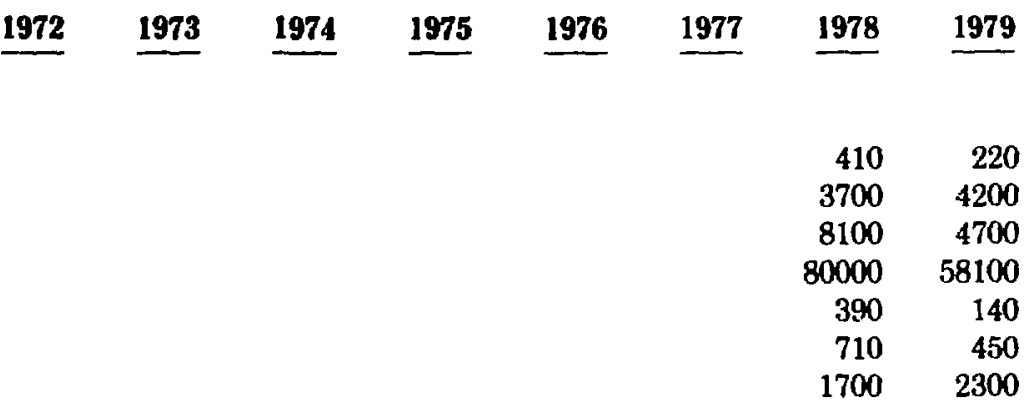

Acids

Acetic

Hydrochloric

Hydrofluoric

Nitric

Perchloric

Phosphoric

Sulfuric

\section{Gases}

Ammoria

Carbon Monoxide

4200

2700

3200

2600

2600

4900

Chlorine

Freon 12

Hydrogen Fluoride

Nitrogen Oxides

Sulfur Dioxide

Sulfur Hexafluoride

Inorganic Chemicals

Ammonium Hydroxide

Mercury

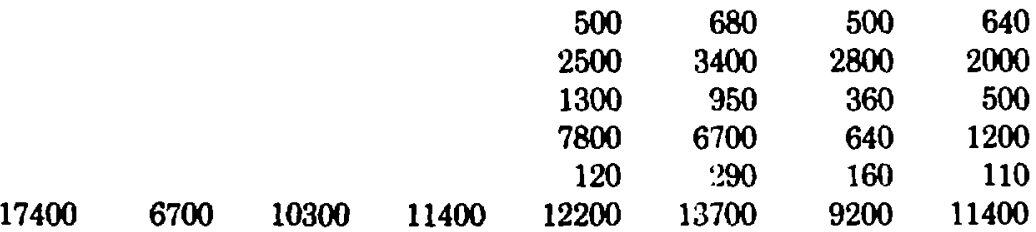

Organic Chemicals

Acetone

Carbon Tetrachloride

Chloroform

Ethanol

Freons

Kerosene

Methanol

Methylene Chloride

Methyl Ethyl Ketone

Perchloroethylene

Toluene

300

360

9200

290

250

16100

15500

12700

10600

8300

250

500

230

$200 \quad 280$

$\begin{array}{lllll}9200 & 10900 & 9900\end{array}$

$\begin{array}{llllllll}10900 & 13300 & 15000 & 10200 & 12400 & 13800 & 8200 & 9200\end{array}$

$\begin{array}{llllllll}8100 & 5000 & 5900 & 4800 & 4600 & 4400 & 3800 & 4100\end{array}$

$\begin{array}{lllll}590 & 540 & 1500 & 1700 & 6600\end{array}$

820

3101000

820

4300

$2600 \quad 3300$

$$
3400
$$

2300

9400

2200

250

170

2300

1000

820

680

10600

$14300 \quad 22000$

Trichloroethane

Trichloroethylene

2100

1200

2700

3300

1000

1400

340

20400

18300

25800

22900

34000

1600

2100

2100

9400

13200

28300

$24100 \quad 23800$

$7400 \quad 6900$ 
TABLE E-XXIII

\section{ESTIMATED CONCENTRATIONS OF TOXIC ELEMENTS AEROSOLIZED BY DYNAMIC EXPERIMENTS}

\begin{tabular}{|c|c|c|c|c|c|}
\hline \multirow[b]{2}{*}{ Element } & \multirow{2}{*}{$\begin{array}{c}1979 \\
\text { Total Uunco } \\
\text { (kg) } \\
\end{array}$} & \multirow{2}{*}{$\begin{array}{c}\begin{array}{c}\text { Percent } \\
\text { Aerosolizod } \\
\text { (\%) }\end{array} \\
\end{array}$} & \multicolumn{2}{|c|}{$\begin{array}{c}\text { Annual Ave. } \\
\text { Concentration } \\
\left(n d / m^{2}\right)\end{array}$} & \multirow{2}{*}{$\begin{array}{c}\text { Applieable } \\
\text { Standerd } \\
\left(n d / m^{3}\right)\end{array}$} \\
\hline & & & $4 \mathrm{~km}$ & $8 \mathrm{~km}$ & \\
\hline Uranium & 568 & 10 & 0.06 & 0.02 & $9000^{\circ}$ \\
\hline $\mathrm{Be}$ & 10 & 2 & 0.0003 & 0.0001 & $\begin{array}{c}10^{\circ} \\
\text { (30 day avg) }\end{array}$ \\
\hline $\mathbf{P b}$ & 0.1 & $100^{c}$ & 0.0001 & 0.00005 & $\begin{array}{l}10000^{b} \\
\text { (for total heavy } \\
\text { metals, } N>21 \text { ) }\end{array}$ \\
\hline
\end{tabular}

- ERDA Manual Chapter 0524.

'Section 201 of the Ambient Air Quality Standards and Air Quality Control Regulations adopted by the New Mexico Health and Social Services Board, April 19, 1974.

‘Assumed percentage aerosolization. 
TABLE E-XXIV

\section{SANITARY BEW AGE TREATMENT FACILITIES} BPFLUENT QUALTY SUMMARY.

\begin{tabular}{|c|c|c|c|c|c|c|c|}
\hline $\begin{array}{l}\text { Diecharce } \\
\text { Location }\end{array}$ & $\begin{array}{c}\text { Permil } \\
\text { Conotituents }\end{array}$ & $\begin{array}{c}\text { No. of } \\
\text { Deviations }\end{array}$ & $\begin{array}{l}\text { Rance of } \\
\text { Deviation } \\
\text { Limit Ration } \\
\text { or pH }\end{array}$ & $\begin{array}{l}\text { Diecharise } \\
\text { Locatlon }\end{array}$ & $\begin{array}{c}\text { Permit } \\
\text { Constituents }\end{array}$ & $\begin{array}{c}\text { No. of } \\
\text { Deriations }\end{array}$ & $\begin{array}{c}\text { Rance of } \\
\text { Devintion/ } \\
\text { Limit Ratios } \\
\text { or pH } \\
\end{array}$ \\
\hline \multirow{5}{*}{$\begin{array}{l}\text { TA-3 } \\
10401\end{array}$} & BOD: & 0 & $\ldots$ & \multirow[t]{5}{*}{$T A-41$} & BOD, & 2 & $1.5-1.8$ \\
\hline & TSS $^{c}$ & 1 & 1.6 & & TSS & 1 & 1.7 \\
\hline & Focal Coliform" & 0 & $\ldots$ & & Fecal Coliforma & 2 & $10 \cdot 19.1$ \\
\hline & Fow (MGD) & 0 & -.. & & Flow (MGD) & 2 & $1.0-1.2$ \\
\hline & pHe & 0 & ... & & $\mathrm{pH}$ & 1 & 4.15 \\
\hline \multirow[t]{4}{*}{ TA.9 } & BOD. & 0 & $\ldots$ & \multirow[t]{4}{*}{$\mathrm{TA}-46$} & BOD, & 0 & ... \\
\hline & TSS & 0 & $\ldots$ & & TSS & 0 & -.. \\
\hline & Flow (MGD) & 72 & $1.0 \cdot 17.6$ & & Flow (MGD) & 155 & $1.0 \cdot 3.0$ \\
\hline & $\mathrm{pH}$ & 0 & $\ldots$ & & pH & 0 & $\cdots$ \\
\hline \multirow[t]{4}{*}{ TA-16 } & BOD, & 0 & $\cdots$ & \multirow[t]{4}{*}{ TA-48 } & BOD, & 0 & $\cdots$ \\
\hline & TSS & 0 & $\ldots$ & & TSS & 0 & $\ldots$ \\
\hline & Mow (MGD) & o & $\ldots$ & & Flow & 0 & $\cdots$ \\
\hline & pH & 0 & $\ldots$ & & $\mathrm{pH}$ & 0 & ... \\
\hline \multirow[t]{4}{*}{ TA-18 } & BOD, & 0 & $\ldots$ & \multirow[t]{4}{*}{ TA.53 } & $B O D$ & 0 & $\ldots$ \\
\hline & $\mathrm{TSS}$ & 1 & 1.3 & & TSS & 2 & $1.6 \cdot 1.7$ \\
\hline & Flow (MGD) & 113 & $1.0 \cdot 18.8$ & & Flow & 38 & $1.0-1.6$ \\
\hline & pH & 1 & 9.5 & & pH & 11 & $9.2-11.0$ \\
\hline \multirow[t]{5}{*}{ TA-21 } & BOD, & 0 & $\cdots$ & \multirow[t]{5}{*}{ TA-35 } & BOD, & 1 & 1.2 \\
\hline & TSS & o & ... & & TSS & 2 & $1.3 \cdot 1.8$ \\
\hline & Focal Coliformo & 6 & $1.46 \cdot 300$ & & Flow (MGD) & 3 & $1.1-1.2$ \\
\hline & Flow (MGD) & 0 & $\ldots$ & & $\mathrm{pH}$ & 2 & $9.3 \cdot 9.6$ \\
\hline & pH & 0 & $\cdots$ & & & & \\
\hline
\end{tabular}

- Single NPDES permit NM 0028355.

-BOD, limits are $30 \mathrm{mg} / \mathrm{l}$ (20-day avg), $45 \mathrm{mg} / \mathrm{l}$ (7-day avg).

TSS limits are $30 \mathrm{mg} / \mathrm{l}$ (20-day avg), $45 \mathrm{mg} / \mathrm{l}$ (7-day avg).

- Fecal coliform limits are 2000/100 me (daily max) and 1000/100 me (geometric mean).

"pH limits not less than 6.0 or greater than 9.0 atandard units. 


\begin{tabular}{|c|c|c|c|c|c|}
\hline $\begin{array}{c}\text { Discharge } \\
\text { Category }\end{array}$ & $\begin{array}{l}\text { No. of } \\
\text { Outfalls }\end{array}$ & $\begin{array}{c}\text { Permit } \\
\text { Constituonts }\end{array}$ & $\begin{array}{c}\text { Ne. of } \\
\text { Dovintions }\end{array}$ & $\begin{array}{c}\text { Rance of } \\
\text { Deviation/Limit } \\
\text { Ratios or pH } \\
\end{array}$ & $\begin{array}{l}\text { No. of Out- } \\
\text { falle Caunins } \\
\text { Deviations }\end{array}$ \\
\hline Power Plant & $6^{c}$ & $\begin{array}{l}\text { TSS } \\
\text { Free Cl } \\
\text { pH }\end{array}$ & $\begin{array}{c}12 \\
1 \\
14\end{array}$ & $\begin{array}{c}4.7-399.8 \\
1.2 \\
1.3-11.6\end{array}$ & $\begin{array}{l}1 \\
1 \\
4\end{array}$ \\
\hline Boiler Blowdown & $3^{c}$ & $\begin{array}{l}\text { TSS } \\
\mathrm{Fe} \\
\mathrm{Cu} \\
\mathrm{P} \\
\mathrm{pH}\end{array}$ & $\begin{array}{c}0 \\
1 \\
14 \\
3 \\
38\end{array}$ & $\begin{array}{c}\ldots . . \\
1.2 \\
1.0-21.5 \\
1.0-1.1 \\
\theta .5-12.1\end{array}$ & $\begin{array}{l}0 \\
1 \\
3 \\
2 \\
3\end{array}$ \\
\hline $\begin{array}{l}\text { Treated Cooling } \\
\text { Water }\end{array}$ & 35 & $\begin{array}{l}\text { TSS } \\
\text { Free Cl } \\
\text { P } \\
\text { pH }\end{array}$ & $\begin{array}{l}1 \\
0 \\
0 \\
0\end{array}$ & $\begin{array}{c}1.16 \\
\ldots \\
\ldots \\
\ldots\end{array}$ & $\begin{array}{l}1 \\
0 \\
0 \\
0\end{array}$ \\
\hline $\begin{array}{l}\text { Noncontact } \\
\text { Cooling Water }\end{array}$ & 29 & $\mathrm{pH}$ & 0 & $\cdots$ & 0 \\
\hline $\begin{array}{l}\text { Radioactive Waste } \\
\text { Treatment Plant } \\
\text { Discharges }\end{array}$ & 2 & $\begin{array}{l}\mathrm{NH}_{\mathbf{b}} \\
\mathrm{COD} \\
\mathrm{TSS} \\
\mathrm{Cd} \\
\mathrm{Cr} \\
\mathrm{Cu} \\
\mathrm{Fe} \\
\mathrm{Pb} \\
\mathrm{Hg} \\
\mathrm{Zr} \\
\mathrm{pH}\end{array}$ & $\begin{array}{l}0 \\
0 \\
0 \\
0 \\
0 \\
2 \\
4 \\
2 \\
0 \\
2 \\
2\end{array}$ & $\begin{array}{c}\ldots \\
\ldots \\
\ldots \\
\ldots \\
\ldots \\
1.1-2.6 \\
1.2-2.8 \\
1.1-2.2 \\
\cdots \\
1.9-2.2 \\
3.4-5.6\end{array}$ & $\begin{array}{l}0 \\
0 \\
0 \\
0 \\
0 \\
2 \\
1 \\
1 \\
0 \\
1 \\
2\end{array}$ \\
\hline $\begin{array}{l}\text { High Explosives } \\
\text { Waste Discharges }\end{array}$ & $20^{d}$ & $\begin{array}{l}\text { COD } \\
\text { TSS } \\
\text { pH }\end{array}$ & $\begin{array}{l}3 \\
2 \\
1\end{array}$ & $\begin{array}{c}1.1-50.4 \\
1.4-1.7 \\
5.5\end{array}$ & $\begin{array}{l}3 \\
2 \\
1\end{array}$ \\
\hline $\begin{array}{l}\text { Photo Waste } \\
\text { Discharges }\end{array}$ & 15 & $\begin{array}{l}\mathrm{Cn} \\
\text { TSS } \\
\mathrm{pH} \\
\mathrm{Ag}\end{array}$ & $\begin{array}{l}0 \\
0 \\
0 \\
4\end{array}$ & $\begin{array}{c}\ldots \\
\ldots \\
2.0-33.6\end{array}$ & $\begin{array}{l}0 \\
0 \\
0 \\
3\end{array}$ \\
\hline $\begin{array}{l}\text { Printed Circuit } \\
\text { Board Develop- } \\
\text { ment Wastes }\end{array}$ & 1 & $\begin{array}{l}\mathrm{COD} \\
\mathrm{Cu} \\
\mathrm{Fe} \\
\mathrm{Ni} \\
\mathbf{P} \\
\mathrm{pH}\end{array}$ & $\begin{array}{l}0 \\
1 \\
3 \\
0 \\
0 \\
2\end{array}$ & $\begin{array}{c}\ldots .8 \\
2.8 \\
1.31-13.0 \\
\ldots \\
\cdots \\
5.7-5.8\end{array}$ & $\begin{array}{l}0 \\
1 \\
0 \\
0 \\
1\end{array}$ \\
\hline
\end{tabular}


TABLE E-XXV (Cont)

\begin{tabular}{|c|c|c|c|c|c|}
\hline $\begin{array}{l}\text { Discharge } \\
\text { Category }\end{array}$ & $\begin{array}{l}\text { No. of } \\
\text { Outfalls }\end{array}$ & $\begin{array}{c}\text { Permit } \\
\text { Constituents }\end{array}$ & $\begin{array}{c}\text { No. of } \\
\text { Deviations }\end{array}$ & $\begin{array}{c}\text { Range of } \\
\text { Deviation/Limil } \\
\text { Ratios or } \mathbf{p H}^{\mathbf{b}}\end{array}$ & $\begin{array}{l}\text { No. of Out- } \\
\text { falls Causing } \\
\text { Deviations }\end{array}$ \\
\hline $\begin{array}{l}\text { Acid Dip Tank } \\
\text { Rinse }\end{array}$ & $1^{\circ}$ & $\begin{array}{l}\mathrm{Cu} \\
\mathrm{pH}\end{array}$ & $\begin{array}{l}2 \\
1\end{array}$ & $\begin{array}{c}2.2-11.0 \\
2.5\end{array}$ & $\begin{array}{l}1 \\
1\end{array}$ \\
\hline $\begin{array}{l}\text { Gas Cylinder } \\
\text { Cleaning Waste }\end{array}$ & 1 & $\begin{array}{l}\text { TSS } \\
\mathrm{P} \\
\mathrm{pH}\end{array}$ & $\begin{array}{l}0 \\
0 \\
0\end{array}$ & $\begin{array}{l}\cdots \\
\ldots\end{array}$ & $\begin{array}{l}0 \\
0 \\
0\end{array}$ \\
\hline
\end{tabular}

-Summary of reports to EPA or NPDES Permit NM 0028355.

${ }^{b} \mathrm{pH}$ range limit on all outfalls is not less than 6.0 or greater than 9.0 standard units.

'Outfalls responsible for deviations scheduled for correction.

aSix of 20 outfalls responsible for deviations scheduled for correction.

eSource of excess $\mathrm{Cu}$ violations removed in 1979. 
TABLE E-XXVI

QUALITY OF EFFLUENTS FROM LIQUID RADIOACTIVE WASTE TREATMENT PLANTS

\begin{tabular}{|c|c|c|c|c|}
\hline \multirow[b]{3}{*}{$\begin{array}{c}\text { Radioactive } \\
\text { Isotopes }\end{array}$} & \multicolumn{4}{|c|}{ Waste Treatment Plant Location } \\
\hline & \multicolumn{2}{|r|}{ TA-50 } & \multicolumn{2}{|c|}{ TA-21 } \\
\hline & $\begin{array}{c}\text { Activity } \\
\text { Released } \\
\text { (mCi) } \\
\end{array}$ & $\begin{array}{c}\begin{array}{c}\text { Average } \\
\text { Concentration } \\
(\mu \mathrm{Ci} / \mathrm{m} \ell)\end{array} \\
\end{array}$ & $\begin{array}{c}\text { Activity } \\
\text { Released } \\
\text { (mci) } \\
\end{array}$ & $\begin{array}{c}\begin{array}{c}\text { Average } \\
\text { Concentration } \\
(\mu \mathrm{Ci} / \mathrm{m} l)\end{array} \\
\end{array}$ \\
\hline${ }^{20} \mathrm{Pu}$ & 1.705 & $0.035 \times 10^{--}$ & 0.057 & $0.04 \times 10^{-}$ \\
\hline${ }^{*} \mathrm{Pu}$ & 0.55 & $0.011 \times 10^{-}$ & 0.087 & $0.054 \times 10^{-4}$ \\
\hline "Mm & 4.68 & $0.096 \times 10^{-0}$ & 0.587 & $0.366 \times 10^{-1}$ \\
\hline$\cdots \mathrm{Sr}$ & 6.07 & $0.125 \times 10^{-}$ & 0.031 & $0.019 \times 10^{-}$ \\
\hline${ }^{*} \mathrm{Sr}$ & 14.16 & $2.91 \times 10^{-7}$ & 0.065 & $0.405 \times 10^{-7}$ \\
\hline${ }^{2} \mathrm{H}$ & 32700 & $0.67 \times 10^{-3}$ & 440 & $0.27 \times 10^{-1}$ \\
\hline${ }^{129} \mathrm{Cs}$ & 170 & $0.35 \times 10^{-6}$ & 0.966 & $0.060 \times 10^{-8}$ \\
\hline imU & 0.21 & $0.043 \times 10^{-1}$ & 2.2 & $0.137 \times 10^{-7}$ \\
\hline${ }^{m} U$ & 0.20 & $0.041 \times 10^{-7}$ & ... &.- \\
\hline
\end{tabular}

\begin{tabular}{|c|c|c|}
\hline \multirow{3}{*}{$\begin{array}{c}\text { Nonradioactive } \\
\text { Constituents }\end{array}$} & \multicolumn{2}{|c|}{ Waste Treatment Plant Location } \\
\hline & TA-50 & TA-21 \\
\hline & $\begin{array}{c}\text { Average } \\
\begin{array}{c}\text { Concentration } \\
(\mathrm{mg} / l)\end{array} \\
\end{array}$ & $\begin{array}{c}\text { Average } \\
\text { Concentration } \\
(\mathrm{mg} / \mathrm{l})\end{array}$ \\
\hline $\mathrm{Cd}^{\mathrm{a}}$ & 0.001 & 0.25 \\
\hline $\mathrm{Ca}$ & 74.4 & 23.2 \\
\hline $\mathrm{Cl}$ & 50 & 69 \\
\hline $\mathrm{Cr}^{\mathbf{e}}$ & 0.022 & 0.25 \\
\hline $\mathrm{Cu}^{\mathbf{a}}$ & 0.41 & 0.16 \\
\hline $\mathbf{F}$ & 2.9 & 392 \\
\hline $\mathrm{Hg}^{\mathbf{a}}$ & 0.003 & 0.0009 \\
\hline $\mathbf{M g}$ & 6.3 & 6.5 \\
\hline $\mathrm{Na}$ & 489 & 2947 \\
\hline $\mathrm{Pb}^{*}$ & 0.046 & 0.089 \\
\hline $\mathrm{Zn}^{*}$ & 0.22 & 0.79 \\
\hline $\mathrm{CN}$ & 0.04 & $\ldots$ \\
\hline COD & 60 & 87 \\
\hline $\mathrm{NO}_{2}(\mathrm{~N})$ & 156 & 605 \\
\hline $\mathrm{PO}_{4}$ & 1.07 & 4.54 \\
\hline TDS & & 6694 \\
\hline $\mathrm{pH}^{2}$ & $9.1-12.8$ & $5.4-12.5$ \\
\hline Total Effluent Volume & $4.858 \times 10^{2} \ell$ & $1.604 \times 10^{\circ} \ell$ \\
\hline
\end{tabular}


TABLE E-XXVII

\section{CHEMICAL QUALITY OF WATER IN VICINITY OF FENTON HILL (average of a number of analyses)}

\begin{tabular}{c} 
Surface \\
Water \\
\hline
\end{tabular}

\section{Water}

Supply

$$
\begin{array}{r}
9 \\
18
\end{array}
$$

No. of Analyses

Chemical (mg/l)

$\mathrm{SiO}_{2}$
$\mathrm{Ca}$
$\mathrm{Mg}$
$\mathrm{Na}$
$\mathrm{CO}$,
$\mathrm{HCO}$,
$\mathrm{SO}$,
$\mathrm{Cl}$
$\mathrm{F}$
$\mathrm{NO}$,
$\mathrm{TDS}$
$\mathrm{Hard}$
pH
Conductance
(mS/m)

No. of Stations"

18

4
8
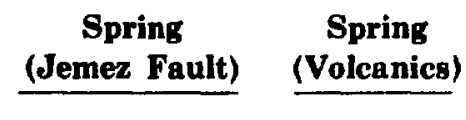

\begin{tabular}{c} 
Abandon \\
Well \\
\hline
\end{tabular}

Fenton Hill

(Pond Fluid)

2

1
2

\begin{tabular}{|c|c|c|}
\hline $10 \pm 10$ & $74 \pm 14$ & $48 \pm 7$ \\
\hline $27 \pm 14$ & $18 \pm 12$ & $89 \pm 40$ \\
\hline $5 \pm 3$ & $4 \pm 2$ & $24 \pm 8$ \\
\hline $28 \pm 26$ & $16 \pm 2$ & $500 \pm 269$ \\
\hline $0 \pm 0$ & $0 \pm 0$ & $0 \pm 0$ \\
\hline $80 \pm 62$ & $79 \pm 21$ & $602 \pm 305$ \\
\hline $34 \pm 64$ & $4 \pm 3$ & $32 \pm 3$ \\
\hline $15 \pm 21$ & $7 \pm 7$ & $977 \pm 593$ \\
\hline \pm 0.3 & $0.5 \pm 0.2$ & $3.1 \pm 0.9$ \\
\hline $1.3 \pm 0.6$ & $2 \pm 1$ & $2 \pm 1$ \\
\hline $242 \pm 129$ & $189 \pm 36$ & $2719 \pm 1418$ \\
\hline $87 \pm$ & $63 \pm 34$ & $322 \pm 117$ \\
\hline $7.3 \pm$ & $7.5 \pm 0.3$ & $6.8 \pm 0.4$ \\
\hline $37 \pm$ & $20 \pm 7$ & $388 \pm 1$ \\
\hline
\end{tabular}

$47 \pm 4$

$12 \pm 1$

$3 \pm 0$

$15 \pm 1$

$0 \pm 0$

$69 \pm 7$

$3 \pm 3$

$3 \pm 0$

$1.1 \pm 0.0$

$2 \pm 1$

$114 \pm 23$

$43 \pm 3$

$7.3 \pm 0.5$

$15 \pm 1$
1

$72 \pm 11$

$25 \pm 1$

$8 \pm 1$

$111 \pm 9$

$0 \pm 0$

$337 \pm 1$

$2 \pm 0$

$4 \pm 1$

$1.0 \pm 0.1$

$1 \pm 0$

$446 \pm 14$

$94 \pm 1$

$7.2 \pm 0$

$73 \pm 2$
3

6

asmpling locations key on Fig. 21 as follows:

Surface Water-Locations F, J, N, Q, R, S, T, U, V.

Water Supply-Locations JS 2-3, JS 4-5, FH-1, 4.

Springs (Jemez Fault)-Locations JF-1, JF-5.

Spring (Volcanics)-Location 31.

Abandon Well--Location 27.

Fenton Hill (pond fluids - three ponds containing drilling fluids and circulation fluids from tests. 


\section{GLOSSARY}

alpha particle

beta particle

CG (Concentration Guide)

Curie

gamma radiation

gross alpha

gross beta

man-rem

MCL (Maximum Contaminant Level)
A charged particle (identical to the helium nucleus) composed of two protons and two neutrons that is emitted during decay of certain radioactive atoms. Alpha particles are stopped by several centimeters of air or a sheet of paper.

A charged particle (identical to the electron) that is emitted during decay of certain radioactive atoms. Most beta particles are stopped by $0.6 \mathrm{~cm}$ of aluminum or less.

The concentration of radioactivity in air or water that is determined to result in whole body or organ doses equal to ERDA's Radiation Protection Standards for external and internal exposures if the air is continuously inhaled or the water is the sole source of liquid nourishment throughout the year.

A special unit of radioactivity. One curie equals $3.70 \times 10^{10}$ nuclear transformations per second (abbreviated $\mathrm{Ci}$ ).

Short-wavelength electromagnetic radiation of nuclear origin which has no mass or charge. Because of its short wavelength, gamma radiation can cause ionization. Other electromagnetic radiation (microwaves, visible light, radio waves, etc.) have longer wavelengths (lower energy) and cannot cause ionization.

The total amount of measured alpha activity.

The total amount of measured beta activity.

The sum of radiation exposures received by a population. For exampie, two persons each with a 0.5 rem exposure have received man-rem. Also, 500 people each with an expos're of 0.002 rem have received one man-rem.

Maximurn permissible level of a contaminant in water specified by the EPA that is delivered to the free flowing outlet of the ultimate user of a public water system (see Appendix A and Table A-III). 
rem

RPS (Radiation Protection Standard)

total uranium

tuff
The unit of radiation dose equivalence which takes into account difference effects on humans of various kinds of ionizing radiation and permits them to be expressed on a common basis.

Standards for external and internal exposure to radioactivity as defined in ERDA Manual Chapter 0524 (see Appendix A and Table A-II in this report).

Uranium having the isotopic content of uranium in nature $\left(99.27 \%{ }^{28} \mathrm{U}, 0.72 \%{ }^{2 n} \mathrm{U}, 0.0057 \%{ }^{284} \mathrm{U}\right)$.

Rock of compacted volcanic ash and dust. 